"On the National Socialist organisation NSV:

'NS-People's Welfare', propaganda and influence from 1933-1945"

\author{
by \\ Cecilia A.A. Smith, B.A. \\ Thesis submitted for the degree of \\ Doctor of Philosophy \\ University of Edinburgh
}

1986

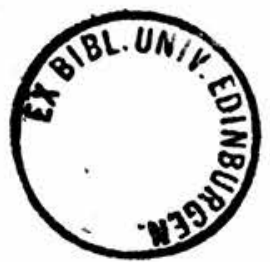


I declare that the content of this thesis is my own original work. 


\section{ABSTRACT}

The National Socialist organisation the NS-Volkswohlfahrt was officially recognised by the Nazi Party on the 3rd May 1933. From modest beginnings in the 'Kampfzeit', the NS-Volkswohlfahrt (NSV) grew into a huge organisation which provided welfare both in the Altreich and in the occupied territories (from 1940) for the Volksdeutsche populations living there.: Decidedly uncharitable in emphasis, the NSV intended to provide aid only for those deemed 'worthy' to receive the benefits of Nazi welfare. The NSV, from 1933/4, provided a whole range of social welfare, from help in kind which was distributed by the charity scheme the Winter Aid, to welfare for expectant mothers. The youth of the nation were not neglected by the NSV, and it became enthusiastically involved in providing kindergarten care for 'Aryan' children who were regarded to be 'biologically healthy' as well. The NSV slowly came to replace the kindergartens of the churches with its own facilities and from 1941, the churches would increasingly find that the NSV had taken over the running of their kindergartens and pre-school arrangements. At the decision-making level the churches would find that they had lost total control, even though church personnel were allowed to continue working in the kindergartens themselves. By 1942, the NSV was fully established and the racial policies of the regime would be reflected in all of the measures provided by the Party organisation. Welfare for women would fully support the goals of the regime by encouraging, through certain support measures, a rise in the German birth-rate. Given the already existing system of state welfare in Germany the NSV did not have everything its own way; the organisation would have to be prepared to cooperate with state officials who, only at first, welcomed the creation of an extra set 
of facilities which could offer much needed help. But the relations between state and Party officials would soon begin to sour when it was realised that the NSV had ambitions which extended into the state system itself. The increasing difficulties which the German welfare system experienced were caused by 'double' welfare provisions coming from Party and state, neither of which wished to see its power and influence reduced by a rival. These uncooperative practices would run through the whole welfare, system to the detriment of the actual provisions of social welfare. This thesis covers the period from 1933 to 1945, and it is argued that the impact of the problems of Party and state in Nazi Germany filtered down into the social welfare system. For this reason, a study of social welfare from 1933 in Germany reveals the effects of the social and political problems of the regime as they affected substantive areas of the welfare system. The nature of the irrational juxtaposition of charismatic and rational grounds of authority, as it existed in Nazi Germany, is referred to in the thesis. State welfare officials who were constrained by the need to conform with the rules and regulations of the state bureaucracy, inevitably came into conflict with the NSV which was dedicated to pursuing ideological aims. These aims, even when they were described as 'rational', came into conflict with the state officials' comprehension of rationally achievable goals. The two versions of 'rationality' perhaps came to destroy any hope of the state and the Party being able to work fruitfully together, virtually until the end of the war. 


\section{ACKNOWLEDGEMENTS}

For the help and advice of Dr. Jill Stephenson of the University of Edinburgh whose continued patience ensured the completion of this work, I am deeply indebted; to her goes my sincere thanks for all the hard work undertaken on my behalf. I am also grateful to Mr. Terry Cole of the University of Edinburgh for his advice and help. I received particularly valuable assistance from Miss Elizabeth Harvey of St. Antony's College, Oxford, who gave helpful information at a critical point. The Economic and Social

Research Council was generous enough to provide a studentship in order that I could undertake this work and the German Historical Institute, London, very kindly provided a scholarship to enable me to travel to Germany. I have received invaluable help from the staff of the Edinburgh University Library who consistently met my demands. To the Wiener Library, London, goes a special thanks, and $I$ am also grateful for the help and advice which was provided by the staff of both the Bundesarchiv Koblenz and the Berlin Document Center. To my typist, Mrs. Dorothy Pilling, goes a specially warm thanks for undertaking to produce the typed script in a very short space of time. I am also indebted to my husband for his help and his patience, and also to my daughter Lisa A. Smith, who provided valuable secretarial assistance at critical moments. The content of the work and its various shortcomings are my responsibility alone. 


\section{CONTENTS}

Abstract

PAGE NO.

Acknowledgements

Introduction

CHAPTER ONE THE DEVELOPMENT OF THE NS-VOLKSWOHLFAHRT

Social Welfare in the 'Kampfzeit' 1

Developments in Welfare Provisions at 14

Gau Level from 1930-33

The founding of the NS-Volkswohlfahrt in 17

CHAPTER TWO THE INTEGRATION OF THE NSV WITHIN THE

SYSTEM OF SOCIAL WELFARE IN GERMANY

CHAPTER THREE THE WINTERHILFSWERK OF THE NSV 72

Ideology and Weltanschauung 72

The Winterhilfswerk Drives 1933-39 95

The beginning of War-Time Winter Aid 126

CHAPTER FOUR MUTTER UND KIND 133

NSV Welfare for Mothers and Infants 133

$\begin{array}{ll}\text { The Finances of MuK } & 167\end{array}$

Nazi population policies: success 178

or failure?

CHAPTER FIVE THE YOUTH WELFARE SECTION OF THE NSV 194

The Organisation of the NS-Jugendhilfe 205

Troubled Relations between the NSV and 233

State Facilities for Youth Care

The NSV and the Churches: An Overview 254

CHAPTER SIX THE HEAL TH CARE MEASURES OF THE NSV

Kinderlandverschickung (KLV) $\quad 275$

$\begin{array}{ll}\text { The Kindergartens of the NSV } & 287\end{array}$

NS-Schwesternschaft $\quad 315$

TB-Hilfswerk $\quad 327$ 
PAGE NO.

CHAPTER SEVEN WAR-TIME ACTIVITIES OF THE NSV: WELFARE

IN THE OCCUPIED AREAS AND THE AL TREICH

DURING THE WAR

Fanfares of Victory

Winterhilfswerk in war-time

353

Mutter und Kind in war-time

373

War-time Juvenile Care 381

Evacuation/Aid for the Bombed Areas 401

Postscript

Bibliography

NSV welfare schemes

431

Organisational outline 435

List of Leading NSV Officials 436

Glossary and List of Abbreviations 
From $1933 / 34$ the system of social welfare in Germany was required to meet the increasing claims coming from the Party organisation the NS-Volkswohlfahrt (NSV) which had been created in May 1933 to provide additional (zUstandige) welfare. A study of the organisation of the NSV must inevitably take into account the relationship which existed between the Party organisation and the system of social welfare which was run by the state. ${ }^{1}$ The NSV was introduced into a well-developed and sophisticated system of welfare which had been greatly expanded during the time of the Weimar Republic. ${ }^{2}$ But the NSV leadership was ambitious, and not always content merely to provide an 'additional' set of provisions. It sought to insert the organisation fully within the 'primary' responsibilities of social welfare, such as juvenile care, according to the statutory provisions of the law. These ambitions pointed to a desire to become a competent welfare agency, which could, when fully developed, replace the state's facilities at some future date.

The structure of the NSV can best be described as falling into three mains parts: Winterhilfswerk (WHW) or Winter Aid, a huge NSV organised charity scheme which came under the control of the Propaganda Ministry, specific health-oriented measures such as the running of holiday/recuperation schemes, including welfare for mothers and the provision of kindergartens, and lastly, the NSV's own juvenile welfare section the NSV-Jugendhilfe. The three-fold division of the NSV's basic structure reflected the development of an organisation, which had begun its semi-official existence as a

1. See Chapter Two.

2. See Chapter Five. 
winter-time aid scheme in Berlin in 1932 with Goebbels' support. From May 1933, the NSV would also undertake to organise welfare for mothers and children (the Mutter und Kind section was formed in the summer of 1934) and lastly, the arrangements for juvenile care (also 1934). From this time, the NSV would undertake to provide welfare measures which, to some degree or another, were already being provided by state officials and the local communities. However, far from immediately viewing the Party organisation with distrust, at first state officials seemed to welcome the participation of an extra set of social welfare arrangements which could offer both help and additional personnel when needed. Indeed this function was the one which had been written into Hitler's official acknowledgement of 3rd May 1933. Neither in 1933, nor in 1944, when new regulations came into force by the express order of Hitler, was it intended that Party welfare should be used as a replacement for the entire state welfare system, even though one study of the NSV has claimed that this was the case. ${ }^{1}$ Not even during the war, when the NSV began to expand its entire operation, did Party welfare facilities completely oust those of the state.

Nevertheless it is true to say that from the beginning of the war, there developed a greater NSV participation in child and youth care. This was entirely with the support of Dr. Conti, the head of the Office for the People's Health. It can be argued that Conti's support would have an important effect upon the future development of the NSV which only the worsening conditions of the war could interrupt. New regulations in 1941 promised a greater NSV

1. Mark Siegel, 'The National Socialist People's Welfare Organisation 1933-1939: The Political Manipulation of Welfare', University of Cincinnati PhD thesis 1976. 
involvement in infant welfare, child care measures including kindergartens which included the assumption of control over all new kindergartens which would be built for the purpose of meeting the demands of an expected (or hoped for) increase in the numbers of working mothers. From 1941, the NSV and the Office for the People's Health cooperated more closely together, and Conti included in his plans for health after the war the full participation of the NSV. ${ }^{1}$ Indeed the NSV came increasingly to function as a people's welfare-care/health-care service. While not itself offering medical treatment of a specific kind, the NSV supplied an extensive welfare service for expectant mothers, and fully supported the drive to make children healthier and better fed. But the NSV also had a right, and a duty, to become involved in the manipulative practices of Menschenfuhrung (the manipulation of social attitudes). This was seen as a prime responsibility of Party welfare. It was with great enthusiasm that this role would be undertaken in all sections of the NSV, from Winter Aid, to welfare for expectant mothers.

By 1936 the NSV's position within the German social welfare system was firmly established, as leading officials in the state welfare offices knew only too well. Officials such as Karl Fiehler, the leader of the Deutscher Gemeindetag, ${ }^{2}$ and champion of all state welfare, would come to realise that the NSV was seriously challenging

1. BA, R18/3793, speech given by Dr. Conti, 'Zur Neuordnung des Gesundheitswesen nach dem Siege', n.d. (?1943).

2. The Deutscher Gemeindetag (DGT) represented the interests of state officials. Karl Fiehler was also head of the Hauptamt fur Kommunalpolitik. In these capacities he was in a position to watch over the interests of state welfare officials who looked for support from the DGT and from Fiehler in particular. See also BA, NS 25/124 Fol. 1, VB, 'Der Auftakt der kommunalpolitischen Schulungswoche', 5 th December 1933; Ibid., 'Kommunalpolitik im neuen Deutschland', 6th December 1933. 
state provisions in every one of its various aspects, including public assistance. Attempts to take on the responsibilities of the state would greatly anger many state officials who did not regard the NSV as a fully competent agency. It was frequently pointed out that the voluntary workers (a significant part of the NSV work-force), could hardly be expected to match the valuable contribution made by the trained personnel of the state.

Two other studies of the NSV which exist have stopped short of the war and have tended to describe the NSV mainly from the point of view of the Winter Aid. ${ }^{l}$ This particular NSV measure has been regarded by these studies as the most important of the NSV's welfare scheme. However, it is argued in this thesis that this is to misunderstand the NSV, for there is good reason to believe that child and youth welfare measures were held to be a vital part of NSV welfare by the leader of the NSV, Erich Hilgenfeldt. He and other leading officials made strenuous attempts to develop these particular facilities, and it seems certain that the NSV nursed a growing desire to take over this type of social welfare. The gigantic Winter Aid Scheme, important as it was, does not fully describe the NSV, for the organisation's true ambitions lay with Familienfursorge/family welfare, and the growing NSVJ itself. The Winter Aid Scheme offered little opportunity for an NSV incursion into the existing state welfare system - the state itself did not run a comparable scheme. Indeed, German social welfare was largely characterised by the juvenile welfare system which had been created in 1922-24, and also by other well-established welfare schemes. The NSV would come to

1. See Thomas de Witt, 'The Nazi Party and Social Welfare 19191939', University of Virginia, PhD thesis 1972; Siegel, 'The National Socialist People's Welfare Organisation 1933-1939'. 
cast an envious eye upon the kindergarten provisions of the state, and of the churches too. The NSV was not the Winter Aid with extra summer-time aid schemes existing in a subsidiary manner, as de Witt has tended to show, ${ }^{l}$ but a growing, Party-based system of welfare which, from 1941, promised seriously to threaten state facilities. This meant that the NSV had completely outgrown its original form by 1941. While the leadership had not intended a direct take-over by the NSV, it certainly seems that a victorious Reich would have seen such a development come to the fore.

By $1938 / 39$ the NSV was increasingly seen by state officials to be the 'cause' of serious 'inefficiencies' arising within the welfare system as a whole. The danger of 'Doppelarbeit', was a subject which was raised whenever state officials wished to offer a plausible reason for restricting the developments of the NSV. But it is also true to say that if the NSV had been content to restrict itself to providing welfare in kind from the Winter Aid, and some support measures for mothers and children (and in a modest way, for families as well), then it would have been greeted most warmly by the officials of the state. Instead, given the plans of the Party organisation, NSV welfare was soon regarded mainly as a threat of a future take-over of the entire system of social welfare in Germany. Attempts to protect the state's facilities came to sour the relations between NSV and state officials, who themselves would come to see the NSV as an implacable enemy, bent on replacing every single state facility. However the NSV provided useful measures and ran popular holiday schemes for mothers and also for children (Kinderlandverschickung), and possibly well-run kindergartens as well.

1. Ibid. 
NSV plans frequently came into conflict with state provisions but this did not hold true for every single section of the organisation. It can be argued that the mammoth charity scheme the Winter Aid which distributed the money collected during the months of the winter to those in need, in the form of a donation of welfare in kind (food and fuel in winter), operated as a huge fund raising operation and came directly under Goebbels' control. It remained entirely undisturbed by the jurisdictional problems which seriously affected other NSV provisions. Operations such as welfare for mothers (Mutter und Kind), the care of infants and young children, an organisation of community nurses (NS-Schwesternschaft) run by the NSV, the provision of kindergartens and youth welfare all, at one time or another, came into conflict with state facilities.

The NSV - Youth Welfare Section (NSVJ) would have to deal with serious, and continually arising, jurisdictional problems. This was practically inescapable, for the NSVJ was required to function in 'cooperation' with state officials who were in a position to delegate juvenile welfare cases to the NSVJ according to the law of 1924, the Reichsjugendwohlfahrtsgesetz. Bearing no statutory responsibility to provide welfare for juveniles, the NSV/NSVJ could only take on youth welfare cases in a 'secondary' manner, for the Jugendamter (state youth welfare office) had first responsibility for the care of the young. The state Jugendamter and the Hitler Youth were themselves closely involved in the provision of correctional education, while the NSV provided 'preventive' welfare measures. Indeed the NSVJ did not begin to become significantly committed to the provision of correctional education until 1943.

Perhaps inevitably, the weltanschauliche emphasis of NSV policies, as it is described in this work, falls into the danger of 
becoming one-dimensional and repetitious. But this is because the philosophical basis (if it can be so described) of the policies of the NSV was itself supported by a particularly rigid, narrow frame of reference. It also depended upon a harshly conceived set of irrational propositions about the nature of charity for its inspiration. NSV welfare reflected policies which were based upon a few, rather ill thought-out arguments about the nature, and the function, of aid for the members of the new Nazi Volksgemeinschaft. The NSV perspective was based upon a cruelly conceived idea of 'efficiency' and 'rationality', and the philosophical basis of Party welfare, profoundly influenced as it was by the Nazi obsession with 'purity' and social 'worthiness', was ruthlessly non-charitable in intention. The contribution of the NSV to German social welfare had been conceived out of an ideologically based idea of who should be given the benefits of Nazi welfare - those who deserved it or those who needed it regardless of considerations of 'worth'. As far as the NSV was concerned however, the claims of 'need' could not be separated from those of 'worth', and for this reason a charitably-based conception of social welfare disappeared entirely from NSV aid. The NSV firmly refused to consider social 'worthiness' and 'biological health' apart from ideas about a 'rational' use of scarce resources when allowing its own measures to be put into operation'. From the 'biologically unfit', to 'ineducable' juveniles, all 'hopeless' and 'worthless' cases would either be excluded completely, or placed last in line if they were included in the less serious 'socially unacceptable' categories. But the NSV would be entirely ruthless when it came to discharge its duties from the point of view of 'biological worthiness/biological health' at all times. In this way the NSV fully supported the vicious racial policies of 
the regime. It can also be argued that the NSV was, frequently, more ruthless in this respect than the state youth welfare officials. Indeed some state officials, at least privately, admitted that the 'erbbiologische' theories of the Party hardly stood up to a close examination. Neither did they provide an adequate means of selecting welfare cases which showed promise of a 'good' response to treatment, either in Homes or other facilities. Indeed it is possible to argue that two versions of 'rationality' came to be used by state and NSV officials. On the one hand, the NSV leadership was determined to attach 'rational' aims to its own ideological perspective, while on the other, state officials continued to see the functioning of an 'efficient' welfare service from the point of view of bureaucratically achievable goals. Indeed the NSV would criticise the state's arrangements for being 'too' bureaucratic. As time went on, the two versions of 'rationality' came to dominate the arguments of the officials of state and Party. The NSV was utterly committed to an ideologically motivated idea of 'efficiency', while state welfare officials remained attached to their own particular frame of reference which was the need to respond to their own legal responsibilities to provide welfare. ${ }^{l}$ It was for this reason, among others, that it would become possible for committed Nazi state welfare officials to criticise NSV practices which were regarded by them to 'be so ideologically 'rigid' as to be practically worthless, regarding a 'real' provision of welfare. Not surprisingly perhaps, NSV provisions were also accompanied by ideological training so that

1. Max Weber, see 'Characteristics of Bureaucracy', in 'Bureaucracy', 0. Grusky and G. Miller (eds.), The Sociology of Organisations: Basic Studies, New York 1970 pp.5-11. 
it was impossible to escape from overt attempts by NS officials to mould social attitudes. The facilities for women in the NSV Mutter und Kind section took an emphatic ideological line. This was also relentlessly undertaken in the housewifery and child-care courses provided by the NSF/DFW (the women's organisation) with the cooperation and the guidance of the NSV. The provisions of welfare were seen by the NSV leadership as a means of helping to foster certain qualities in individuals. For example the NSV would demand that their facilities were to be regarded by those receiving aid as a means of 'strengthening' the practice of 'self-help', the continuing and all pervasive theme of NSV welfare. The NSV ceaselessly claimed that it provided aid in order that the 'self-help' abilities of individuals could come into play later.

NSV welfare also provided some support for the government's low-wage policy, and the welfare in kind which came from the Winter Aid was meant to act as a support-mechanism for such a policy. On the other hand, Winter Aid could also be used as a means of 'controlling' the work-force through the practice of refusing to give aid to those who had come into conflict with the regime. The unemployed too would find that a refusal to take on an unpalatable job would lead to the loss of much needed welfare in kind in the winter. But NSV welfare in many cases, was realistically viewed as a hand-out' by the Party to supplement low wages, even though the propaganda of the NSV and the Winter Aid put an opposite view. ${ }^{1}$

Perhaps one of the most ambitious aspects of NSV welfare lay in the attempts to foster new attitudes regarding the role of the citizen in the new Volksgemeinschaft. This emphasis would exist most

1. See Chapter Three. 
clearly in the propaganda which accompanied the Winter Aid drives in the months from October to March every year. The population was bombarded with visual and other reminders of the new responsibilities of the Volk. Indeed, the Winter Aid showed the manipulative side of the NSV most clearly for it joined together propaganda and welfare in a unique way, which has been correctly commented upon. ${ }^{1}$ The Winter Aid would show how the NSV, with the help of the Propaganda Ministry, tried to shape attitudes in the most blatant manner. However, this aspect should not be examined without giving equal consideration to the ambitious developments of NSV health-care/welfare-care provisions. For this reason a study of the NSV needs to include the youth welfare section, NSVJ and the early years of the war. Indeed the early part of the war had an important effect upon the whole future direction of the NSV, ensuring that it would have an important part to play, until 1945, both in the Altreich and in the occupied territories where the NSV would organise welfare for the Volksdeutsche (ethnic Germans) living there. But perhaps inevitably, the conduct of the war also had a negative impact on NSV developments. NSV plans were interrupted by the responsibility to provide a whole new set of measures for the evacuation of the civilian populations from the cities and towns of Germany. The 'largest welfare organisation in the world' came to act as a civilian rescue operation towards the end of the war. It would be this duty which would remain as a last task, both in the Altreich and in the occupied area as well.

\footnotetext{
1. C.W. Guillebaud, The Social Policy of Nazi Germany, Cambridge 1940, p.96. See also de Witt, 'The Nazi Party and Social Welfare 1933-1939'; Siegel, 'The National Socialist People's Welfare Organisation 1933-1939'.
} 
It is argued in this thesis however, that until that time, social welfare in Germany was represented by the double provisions of Party and state. But these provisions were profoundly influenced by two opposing views of a 'rational' and 'efficient' means of carrying them out which, in most cases, were entirely incompatible. This would mean that the time and the efforts of numerous officials of the NSV and the state were kept fully occupied not with the problems of welfare as such, but with the problem of finding the best way to 'protect' their own welfare provisions. In addition, the distinctive socio-political structure of the regime which necessitated the merging of two, theoretically incompatible types of legitimate authority (the 'charismatic' and the 'rational'), profoundly influenced the system of welfare. ${ }^{l}$ The two different perceptions of 'rationality' held by the NSV on the one hand, and state officials on the other, forms a main theme of the thesis. The inability of state and Party officials to cooperate arose out of this problem, and the jurisdictional issues which frequently arose were, much of the time, a manifestation of this fundamental and perhaps unsolvable issue.

1. For an explanation of Weber's analysis of the three 'pure' types of legitimate authority (Rational; Traditional; Charismatic), see Max Weber, 'Bureaucracy', in Grusky and Miller (eds.), The Sociology of Organisations, p.5. 


\section{Social Welfare in the 'Kampfzeit'}

In the Nazi Party's own history of the NS-Volkswohlfahrt (NSV), a brief outline is given of the difficulties which faced the existing welfare services during the 1920s and early 1930s. ${ }^{l}$ Contained in these particular documents is an indication of the Nazi view of the socio-economic situation as it affected the scope and organisation of social welfare measures in the post-war period. Both the health and the welfare services in Weimar Germany had been experiencing periods of difficulty and economic set-back; for example in 1924 the ambitious plans for a national system of juvenile care had to be seriously curtailed only two years after the new laws for child and youth welfare (Reichsjugendwohlfahrtsgesetz) had been drawn up. ${ }^{2}$ It is also true to say that after the war the impact of a rise in prices in Germany was further exacerbated by the difficulty of improving the existing inadequate housing conditions in towns and cities throughout the country. This is to say that a significant proportion of the industrial population was having to endure both a fall in real living standards and severe over-crowding. Such essentials as food, fuel and payment of rent were transformed into luxuries for many ordinary families at this time, and it was this situation, the worsening of the conditions of social life in Germany, which prompted the anonymous author of the history of the NS-Volkswohlfahrt to claim that:

1. HA, Reel 14, Folder 262, pp.1-496.

2. W. Friedlander and E.D. Myers, Child Welfare in Germany before and after Nazism, Chicago/Illinois 1940, p.7. 
'Clemenceau's dream, that twenty million German souls would be shovelled into their graves, seemed to be on the way to be fulfilled.'

Of decisive importance in the development of the Nazi Party's own arrangements for the distribution of welfare aid to its sympathisers and supporters was the growth in mass unemployment and the collapse in $1932 / 33$ of the relatively new system of unemployment insurance which had been established only shortly before in 1927.2 Governments had tried to meet the crisis by making increases in the level of contributions and imposing cuts in benefit. The period during which the full insurance benefit could be claimed was shortened so that the unemployed became dependent upon various public relief organisations, which involved a means test and lower payments all round. $^{3}$ of the 5.8 million unemployed who registered at the labour exchanges in December 1932, 1.3 million were receiving neither benefits nor relief payments of any kind, and to this latter figure must be added the 'invisible' unemployed whose numbers were estimated to be over one million. ${ }^{4}$ of the 4.5 million unemployed who were receiving benefits, only $18 \%$ were receiving the full insurance benefit while some $29 \%$ were being supported by the government's crisis relief scheme. The remainder were dependent on local relief schemes. Timothy Mason has calculated that out of some 7 million unemployed only 792,000, who were in receipt of full insurance

1. $H A, 14 / 262$, p.2.

2. de Witt, 'The Weimar Replublic's Welfare Crisis', in 'The Nazi Party and Social Welfare, 1919-1939', pp.43-55.

3. Ibid.

4. Timothy W. Mason, Sozialpolitik im Dritten Reich: Arbeitsrklasse und Volksgemeinschaft, Opladen 1978, pp.90-91. 
benefit, were sure of having enough to eat. ${ }^{1}$ The average real income of the unemployed, in all categories including the professions, fell by $10 \%$ between 1930 and 1933. If one includes the increases in taxation rates and social insurance contributions, a further 3\% was lost to all wage earners at this time. A realistic figure for the fall in living standards for those in work during the crisis is therefore calculated to be nearer 15\%. ${ }^{2}$ It ought to be remembered that for the lower paid worker this fall represented the important margin between just managing and debt, deprivation and hunger. Though there seems little doubt that the Nazi Party would have eventually established some form of social welfare scheme which would favour a rise in the German birth-rate, it would be misleading in the extreme to suggest that economic hardship and unemployment played an exclusive role in bringing forth Party-sponsored aid. While this was true of the late nineteen twenties, at which time indigent Party activists and the SA (Sturm Abteilung) were supported by the Party, from 1930, when the economic situation worsened and the NSDAP gained significant political victories, it became increasingly urgent that welfare facilities should be established to deal with the growing number of the unemployed, regardless of whether they were members of the NSDAP, or other Nazi supporters. From 1930 social welfare increasingly took on an ideological tone and became the means by which the NSDAP could consolidate its position by extending its welfare facilities to non-Nazis and Nazis alike. ${ }^{3}$

1. Ibid.

2. Ibid.

3. HA, 14/262, 'Wohlfahrtsausschlsse werden besetzt', pp.8-14; Ibid., 'Der NSV-Gedanke taucht auf', pp.154-156. 
The development of National Socialist welfare may be divided into two, one part consisting of those measures which were undertaken almost entirely by the Nazi women's groups from 1923 to 1930, and the other part consisting of measures which, from the end of 1930, became increasingly propaganda-oriented and organised by Party officials and Gau personnel who were, of course, exclusively male. ${ }^{l}$ Social welfare measures were organised and carried out at first by the numerous members of the women's groups, and from 1931 the newly formed NS-Frauenschaft. From 1930/31, there were individually organised Gau welfare arrangements one of which was the newly established NS-Volkswohlfahrt in the Gau Gross-Berlin. ${ }^{2}$ Many individuals, on a voluntary basis, were kept increasingly busy supplying much needed aid for those who were, quite literally in the case of the SA, in the forefront of the political struggle. ${ }^{3}$ Nazi welfare arose mainly as circumstances dictated, with measures being put into operation in a more or less sporadic and uncoordinated fashion. Welfare work which was organised by the individual Gaus only established itself gradually and went under a variety of names, such as $\underline{\mathrm{NS}-\mathrm{Hilfe} \text { and }}$ NS-Nothilfe. ${ }^{4}$ One Gauleiter, Burckel, established a measure called Volksozialistiche Selbsthilfe which name gives some indication of the character of the measures being put into force at that time, given that the emphasis upon self-help was something which would be

1. Ibid., 'Besondere Organisationen entstehen', pp.37-48.

2. Ibid., pp.154-156.

3. Conan Fischer, 'The Occupational Background of the SA's Rank and File Membership during the Depression, 1929-1934', in Peter D. Stachura (ed.), The Shaping of the Nazi State, London 1978, p.147. The unemployment rate for SA men ran as high as $60 \% / 70 \%$ overall while in Prussia it was calculated to be nearer $100 \%$.

4. HA, 14/262, pp. 37-48. 
retained later in all Nazi welfare measures organised by the NSV. Youth welfare was not neglected, and in Munich a special section called Soziale Arbeit was formed and administered by the Hitler Youth (HJ). Even although the NSV was formally given a monopoly within the area of youth welfare, the $\mathrm{HJ}$ would continue to run its own section, in spite of the fact that the NSV eventually took over other previously existing Party organised measures during 1933.

Compared with the scope and complexity of the NSV after 1933, Party-sponsored welfare at the end of the 1920s was a modest affair indeed, consisting mainly of the collection and distribution of essential foodstuffs, articles of clothing, and the provision of hot meals in soup kitchens for unemployed SA men and other Nazi sympathisers. ${ }^{1}$ The importance of examining the provision of welfare as it was undertaken by the Nazi women's groups who were carrying out this work should not be underestimated, for it seems reasonable to suggest that the NSV was able to establish itself more quickly by building upon an already existing, and indeed familiar system, of Nazi welfare - a system moreover, which had been painstakingly established out of the voluntary efforts of the hard-working women who belonged to these groups in the middle and late 1920s. It is possible that without this (albeit tenuous) network of welfare activity, which had been building up throughout the industrial areas, and which was being supplemented by Gau welfare arrangements, the NSV would have had a longer, if not a harder, struggle to convince Party officials in the Spring of 1933 that they, in the NSV, would be able to establish a Party welfare organisation on a national level.

1. Ibid., pp.4-7. 
Before the official recognition was granted by the Party to the NSV, in the early Spring of 1933, the infant organisation seems to have drawn attention to the existence of the welfare network which now existed in addition to the state and denominational arrangements. Moreover, these particular arrangements were regarded, certainly by the NSV and perhaps by Geobbels too, as being ripe for a takeover by a Party agency which would be dedicated to systematizing all previously uncoordinated party sponsored welfare aid. The rapidity with which the new leader of the NSV, Erich Hilgenfeldt, set about this activity from May 1933, when the Party finally agreed to acknowledge the NSV, suggests that such was the case. ${ }^{l}$

In order to understand this Party welfare network, it is necessary to examine the development of the welfare-oriented activities of the various women's groups in the 1920s. In the official history of the NSV it was pointed out that in 1924, fourteen women in Bernburg had gathered together to take over those activities which would leave their male comrades 'free to participate in the political struggle without having to bother themselves with the practical cares of ordinary daily life'. ${ }^{2}$ While the women members and supporters of the other political parties, such as the DDP (Democratic Party), the DVP (People's Party), and the SPD (Social Democratic Party), freely engaged in discussion and interested themselves in feminist and pacifist issues, the expectation of the NSDAP was that their female members and supporters would be allowed to fill supportive roles only. Thus Nazi women were expected, in the main, to be less interested in problems which related to the issue of

1. Ibid., 'Das Winterhilfswerk setzt ein', pp.180-211.

2. Ibid, p.6. 
women's rights than in issues which related to the supportive and nurturant aspect of female activity. Given that feminists per se were anathema to the Nazis, it was made clear that in relation to the political sphere, women in the NSDAP could hope only to fulfil an overtly non-political function, being expected to co-operate with their male Party comrades, not to compete with them. ${ }^{1}$ The supportive work of the women Party members and adherents often enough consisted of attending to the needs of the unemployed SA men who regularly required first-aid treatment after street battles. It was clear from the start that Nazi women would be encouraged to become aware of the significance of the Party's positive redefinition of traditional female roles, to rediscover for themselves the value of the complementary and cooperative nature of feminine activity. ${ }^{2}$ After 1933, through the means of propaganda, the Nazis would try to 'upgrade' female roles by bestowing upon the activities of the housewife and mother a significantly higher status than had hitherto prevailed. ${ }^{3}$ Women were to be encouraged to carry out their work:

'Without asking whether this work was menial or not they did this work quite simply and as a matter of course out of the healthy maternal instinct of the uneducated woman who perceived her strength to lie in a purposeful desire to work and to serve'.

During the period of the Kampfzeit lavish praises which were often directed towards the so-called healthy mother instinct of the ordinary, largely uneducated woman must be seen as a clear attempt to

1. Jill Stephenson, The Nazi Organisation of Women, London 1981. See Introduction, pp.11-20.

2. Jill Stephenson, 'Women in German Society, 1930-40', Ph D thesis, 1974, University of Edinburgh, p.425.

3. Ibid.

4. HA, 14/262, p.6. 
persuade working class women to join, or at least give support to, the NSDAP. Nevertheless, this theme, which would take on an increasingly sentimental tone in the publications of the NSV, continued unabated after 1933, after the partial stoppage of applications for party membership in May of that year. ${ }^{1}$

Although the activities, motivation and organisation of Nazi women have been adequately dealt with elsewhere, ${ }^{2}$ it is necessary here to give a brief indication of how the women's groups in the late 1920s were organised to provide the practical work, which was their main contribution to the provision of welfare. The organisation of the Nazi women's groups existed in three tiers, from local to Reich level. The Brtliche Frauengruppen were intended, insofar as they were involved in welfare work, to restrict their activities to within the boundary of the local branch. According to the history of the NSV this was in order that a systematic arrangement of existing voluntary labour be injected into all welfare activities. ${ }^{3}$ The Arbeitsgemeinschaften v8lkisch gesinnter Frauen operated on a larger scale in, and including, more than one local; it was the Deutscher Frauenorden (Rotes Hakenkreuz) (hereafter DFO) which functioned at both the local and the national levels and took in the largest numbers of Nazi women. It was therefore the 'stärkeste organisation nationalsozialisticher Frauen'. ${ }^{4}$ It has been pointed out that

1. Dietrich Orlow, The History of the Nazi Party: 1933-45, Pittsburgh 1969, p.49.

2. See Stephenson, 'Women in German Society 1930-40'; Women in Nazi Society, London 1975; The Nazi Organisation of Women.

3. $H A, 14 / 262$, p. 5 .

4. Ibid. 
there were two broad strands of women's group activity. There existed firstly, those few women who were paid up Party members, along with those who were the wives, daughters, or other close adherents of male Party members. In addition, there were others who were not connected with the NSDAP but who were members of vblkisch groups which generally shared the aims and prejudices of the NSDAP. As Stephenson points out, the 'common motivation' for participation in the Nazi Party's groups, or in vblkisch groups, 'derived from the catalogue of post-First World War German disasters from the Versailles Treaty to the growth of Bolshevism at home'. ${ }^{1}$ Given the presence of a preparedness to take on the tasks of unpaid voluntary welfare work, the women's groups seem to have supplied an ideal training ground for the future voluntary welfare aides of the NSV.

The DFO had been founded by Elsbeth Zander in Berlin, and until 1931, when the organisation was dissolved, it existed as the largest organisational grouping of Nazi women. ${ }^{2}$ From 1928, with the affiliation of the DFO to the NSDAP, the activities of DFO members were concentrated upon the field of welfare. DFO members were expected to acquaint themselves with current political issues, and gain a useful working knowledge of the law as it affected the sphere of the family. Of the numbers of the female Party members, which in 1930 amounted to 7,625 , one half were DFO members who, because of their involvement in social welfare, may be counted as amateur social

1. Stephenson, The Nazi Organisation of Women, p.25.

2. HA, 14/262, p.5. For an examination of this topic see Stephenson, The Nazi Organisation of Women, pp.28-37. 
workers. ${ }^{1}$ To this figure must be added the numbers of welfare enthusiasts working within the local groups. On the whole it seems safe to say that several hundreds of women were being encouraged, during the later 1920s and early 1930s, to regard themselves as being able to provide a worthwhile contribution within the area of private social welfare, and in addition to that which was being organised by the churches and the other political parties. The type of welfare which was available to needy Nazis in 1929 and 1930, and which was organised by their own female supporters, was not always restricted to hand-outs of food, clothing and a hot meal in a soup kitchen. Children too were given consideration, and wives of Party activists could, when facilities allowed, arrange for their children to be sent on holiday. From 1930 a system of holiday arrangements for children was set up which ran parallel to the already existing governmental schemes. Organised country holidays had been operating in the Berlin area from 1923, when the Berlin State Child Welfare Bureau set up arrangements for holidays for children. It seems likely that the addition of a Nazi organised scheme was inspired by the need to become involved in general family welfare, though the Nazi arrangements were modest in the extreme, with the city of Hamburg managing in 1930 to send only sixty children to the country. ${ }^{2} \mathrm{~A}$ comprehensive system of family care was something the Nazi women were interested in providing, albeit on a very modest scale. All the work

1. HA, 14/262, p.5; pp.13-20 Stephenson, The Nazi Organisation of Women, p.25, and for a description of the training schemes of the Nazi women's organisation, pp.156-172.

2. HA, 14/262, p.18; numbers of children sent on holiday from Hamburg: $1930-60 ; 1931-120 ; 1932-500$. 
which was put together under the general title of 'Familienhilfe', before 1933, was an attempt to provide an all-embracing scheme, something which could be regarded as a 'package deal' of family care. This included, as well as the distributions of food and clothing, the care of children, the sick, and pregnant and nursing mothers. ${ }^{1}$ Clearly there would gradually develop a determination, which was channelled through new Nazi welfare measures, to separate every aspect of the social life of Party members and supporters from the Weimar political system as far as this was possible. All of these measures were of a practical nature but also unavoidably modest at this time, with relatively small groups of hard-pressed women collecting what they could, in order to help their needy comrades who were involved in promoting the Nazi cause. It certainly seems that many were inspired to give time and effort, motivated as they were by a sense of 'sacrifice' which later became the model for the citizens of the Third Reich. ${ }^{2}$

The local women's groups continued to flourish, and increasingly took on the practical work of providing support and material aid for Party activists and supporters. In 1929, the NS-F rauenarbeitsgemeinschaft (FAG) of Neustadt/Aisch in the Gau Franken, sent two crates of foodstuffs to Berlin. ${ }^{3}$ As far as can be discovered, this particular measure seems to have been the forerunner of the later NSV Patengau, or 'donor Gau', system which was run by

1. Ibid., 'Familienhilfe wird geleistet', pp.15-23.

2. Ibid., 'Mittagstische werden eingerichtet und Unterkunft gewahrt', pp.23-29. This may have been true only of the period of the Kampfzeit rather than the peacetime years of the Nazi regime, when the NSV, at least, suffered shortages of personnel.

3. Ibid., p.7. 
the NSV's Winterhilfswerk (Winter Aid Scheme). After 1933, during the winter months, the NSV's Winter Aid saw to it that essential foodstuffs which could be obtained from the surrounding country areas were collected and sent off to towns and cities; Gaus in the country districts were assigned specific industrial areas to which supplies of farm produce were dispatched. For example, the Gau Gross-Berlin could expect to be supplied with produce, paid for by the Winter Aid Scheme, as the need dictated, from LUbeck, Mecklenburg, Pomerania and Kurmark. ${ }^{l}$ In addition, the same hard-working Neustadt/Aisch group, again in 1929, set to work to organise two hundred centres for the distribution of potatoes to unemployed Party members and supporters. This type of measure, again, would later be adopted by the NSV and carried out by the Winter Aid Scheme. Dictated by necessity, these measures of the Nazi women, before 1933, may be described as having laid part of the essential groundwork of the more grandiose schemes of the NSV whose vaunted 'originality' in these matters is thus called into question. ${ }^{2}$

There seems little reason to doubt that in the late 1920s a genuine sense of gratitude was generated among Party activists, and the SA in particular, for the welfare which was provided by the Nazi women, not all of them Party members themselves. The provision of food and clothing, or free meals in an SA canteen, must be counted as an essential lifeline for the growing numbers of impoverished Nazis. The work of the women did not go unacknowledged by the recipients of such welfare as was available at the time. The Frauenarbeitsgemeinschaft Altmark was sent the following letter from

1. See Chapter Three.

2. BA, NSD 30/51, Deine Arbeit: Dein Werk, Berlin, 1942. 
an anonymous member of the SA who had received much needed aid:

'Dear Frau Pgn. L.,

Only now can I write to you to thank you. My comrades and I send to you our heartfelt thanks for your sacrifices and the work which has been undertaken on our behalf. You have never forgotten us and there is not one moment when we do not feel grateful to you. In the name of all my comrades, I thank you and your group.'

From the end of 1930 however, it was becoming clear that the Nazi women's groups could only look forward to participating in a more organised, and significantly expanded, Nazi scheme by playing a minor part. ${ }^{2}$ Indeed, in some new arrangements, they were excluded, as the example of new activities in the Gau Gross-Berlin showed, for the NS-Frauenschaft was effectively prevented from participating in the creation of the NSV in the Berlin area during $1931 .^{3}$ Not surprisingly, however, in the severe economic conditions of 1930 to 1933, it could have hardly been expected that even the hardest working women would be able to provide, and systematically organise, a whole range of welfare activities with the resources which were available to them at that time. An expansion of welfare would need the support of the Party which could itself make funds available to the Gaus, but the Gaus themselves would increasingly have to provide, through collections, for those in need. However, within the area of practical welfare work, it is fair to say that the women's groups had always been at the forefront, with many individuals giving support to those in need. During the period when the Nazis were struggling for political recognition, such practical aid which was made available

1. $H A, 14 / 262$, p.7.

2. Ibid., p.136.

3. Ibid. 
was crucial for the Nazi cause. The Party organisation, the NS-Volkswohlfahrt, owed a particular debt to the Nazi women who had been involved in paving the way for a Party welfare scheme which would eventually challenge, in many areas, the provision of welfare by the state. ${ }^{1}$

\section{Developments in Welfare Provisions at Gau Level from 1930-33.}

During 1930 and 1931 in addition to the massive increase in the numbers of the unemployed there was another important development which was to have a significant effect on the future organisation of Party welfare. This was the success by the NSDAP in the Reichstag election of September 1930, where significant gains made it a political force to be reckoned with: the Party had won some 6.4 million votes, and thus $107 \mathrm{Nazi}$ delegates entered the Reichstag. In order to capitalise on these electoral gains, it became urgent that a completely new arrangement should be set up to deal effectively with an expanded programme of social welfare; inevitably it would be dealt with exclusively by Party officials. ${ }^{2}$ A close connection, therefore, existed between the electoral victory of 1930, an ever worsening economic situation, and the expansion and development of Party welfare throughout the Gaus. Given the appalling hardship which was descending upon all classes in German society, it was absolutely vital that the unemployed, both party members and supporters (including new supporters), be given the full extent of what material assistance could be gathered together. The NSDAP could not afford at this time to lose the foothold which had been gained in popular sympathy, as shown in the election, through failure to

1. BA, R36, Folders 1001; 1996.

2. HA, 14/262, pp. 37-48. 
provide adequate material help for unemployed Party activists, and most importantly, for the increased numbers of actual and potential supporters. From this time on it would be Gau office personnel who would take on the increased responsibility of providing systematic arrangements for welfare at local level. ${ }^{l}$

An overall expansion of Gau office personnel at first preceded, and then accompanied, a steady growth and reorganisation of all Party-sponsored aid. After the Nazi victory in Ammerland in 1930, welfare committees were set up throughout the Gau (Weser-Ems), to supervise the newly created 'welfare districts' which were designed to offer facilities for giving advice, and distributing assistance to 'HilfsbedUrftigen Parteigenossen'. ${ }^{2}$ Significantly, there is a total absence of any reference to participation by the women's groups in these new arrangements, whether on a reduced level or not. It was abundantly clear that, following an expansion of Gau supervised welfare, important decisions would be taken by Party officials alone, that is, by men. As unemployment continued to rise in Germany, so an expanded system of Nazi welfare was established. In the Magdeburg area, for example, it was decided by Party officials that such help as had been previously supplied by the local women's groups was no longer sufficient to meet the swiftly developing economic crisis in the area. ${ }^{3}$ A new social welfare scheme was called into being and given the name Kamaradenhilfe. ${ }^{4}$ The scheme was designed to operate throughout every Ortsgruppe and it was expected that all Party

1. Ibid., pp.8-13; pp.37-48.

2. Ibid.

3. Ibid., p.9.

4. Ibid. 
members and sympathisers in the district would go willingly to the task of organising collections for the Magdeburg Party members whose situation, it was said, was 'truly deplorable'.l Collections were organised in every Ortsgruppe and donations were solicited from Party members, Nazi sympathisers and indeed anyone who was prepared to contribute. While an exaggeratedly rosy picture is given of the success of these particular efforts, with no more than a slammed door to hinder the efforts of the Party workers, it was obvious that the value of the propaganda effect of these collections was not lost on some Party officials at least. When discussions took place after the house-to-house collections it was noted with some interest, and a great deal of satisfaction, that some previously unsympathetic citizens had, in fact, donated something, though not always 'in the required spirit'. ${ }^{2}$ Thus it was decided that, if a donation had been given, however reluctantly, it was to be counted as a 'gain'. ${ }^{3}$ It was in this way that the groundwork for the propaganda activities of the NSV was laid.

One of the Nazi Party's major assumptions had begun to emerge, it manifested itself in the refusal to recognise that passive acquiescence on the part of many who offered this, instead of real support, for Nazi measures was an entirely negative factor. ${ }^{4}$ Such

1. Ibid.

2. Ibid.

3. Ibid., p.9-10.

4. See Stephenson, The Nazi Organisation of Women, pp.160-161, for a description of the contrast between some support for practical training courses for women, as opposed to the unpopularity of the ideological training courses on offer by the DFW (Deutsches Frauenwerk). Membership of the NSV often signalled a desire to be left in peace rather than a sign of active support for the Nazi cause. 
'support' was consistently and deliberately misrepresented, from 1933, by Goebbels' Ministry, as active and enthusiastic support for the Nazi government and its measures. ${ }^{l}$

The founding of the NS-Volkswohlfahrt in the Gau Gross-Berlin

The city of Berlin was, in 1931, a most appropriate place in which to provide an additional scheme of welfare aid. The difficulties which faced the population at the end of that year were seemingly endless, with many people facing economic disaster, poverty and homelessness. The numbers of the unemployed in Berlin were higher, on average, than in the rest of Germany. For example, at the time of the Machtubernahme in January 1933, the number of unemployed per thousand of the population within the Reich was 96.4, whereas in Berlin, the number of the unemployed per thousand of the population came to 152.2. Expressed another way, of every six Berliners, one was out of work, while in the rest of Germany the relationship was $10: 1 .^{2}$

Unemployment in Berlin 1928-1935

\begin{tabular}{rcc} 
Year & Total Number & per 1,000 inhabitants \\
\cline { 2 - 3 } 1928 & 220,395 & 59.9 \\
1929 & 276,101 & 63.8 \\
1930 & 442,106 & 102.0 \\
1931 & 563,997 & 130.7 \\
1932 & 636,298 & 148.9 \\
31.1 .33 & 654,878 & 152.2 \\
1933 & 520,356 & 121.4 \\
1934 & 277,267 & 65.4 \\
31.1 .35 & 211,766 & 49.9
\end{tabular}

1. Reher, Social Welfare in Germany, Berlin 1938, p.12; $B A$, NS 22/751, letter from Hilgenfeldt to Ley including a detailed report of the WHW collections with a breakdown of amounts donated by household and individuals, both at Reich and Gau level, 17th April 1939.

2. David Kramer, 'Das Fursorgesystem im Dritten Reich', in Geschichte der Sozialarbeit, (hrsq.) Rolf Landwehr and RUdeger Baron, Basel 1983, p. 198.

3. Ibid. 
According to the NSV history, the Berlin Statistical Office had reported that a majority of the inhabitants of Berlin were enduring filthy and insanitary conditions in their homes, and the problem of over-crowding was being added to the misery and discomfort of life in the city.

The founding of the NS-Volkswohlfahrt in the Gau Gross-Berlin coincided with that period in the Party's history which saw, at the end of 1931, a consolidation of the Party's organisational systems, with the Party militants '...more firmly integrated into the organisational framework than before...'. I A uniform accounting system had been established in all the Gaus by Schwarz, a necessary measure considering that the Party's full-time staff exceeded at this time one thousand in almost every Gau. Financial troubles too were beginning to be resolved, and successful links had been established with German agricultural interest groups. In mid-1931 a successful onslaught was made on the business community, the tangible results of which were the sums of money which the industrialists made available to the Nazi Party. Membership of the Party had reached approximately 450,000 , and the SA received an increase in membership of 100,000 between December 1931 and February 1932. ${ }^{2}$ The decision by Party officials in the Gau-Gross Berlin to establish a welfare association, one which would be officially registered in the same way as the other independent welfare associations, was no doubt inspired by the general upswing in the Party's fortunes. But it also indicates that some Party officials, at least, felt that there was a need to establish a foothold in Berlin within the area then occupied by the

1. Dietrich Orlow, The History of the Nazi Party: 1919-1933, Pittsburgh 1969, p.239.

2. Ibid. 
Catholic Caritas, the Protestant Innere Mission, and the SPD's Arbeiterwohlfahrt, among others.

It was in the Wilmersdorf district of Berlin that the new welfare association was founded, after numerous discussions between the district adviser of the Communal Policy Department (Kompola), of the Party, Erich Humbert, and other Party officials. ${ }^{l}$ With the growing numbers of Nazi town councillors it was felt that the time had come to set up a new welfare association. Humbert was very well aware of the increasing difficulties which were being experienced by the existing welfare services, and he could, with some justification, point to the necessity for supplying a 'homegrown' association in the city of Berlin. There seems, however, to have existed at this time a strong desire to become involved within the field of independent welfare, which would exist as a real alternative to the other private agencies, and it is this particular goal which distinguishes the Berlin-based association from the other Gaus' organised measures. Whilst other Gaus sought to support the indigent and the poor within their district, it is clear from the start that in Berlin, ambitions went further, and it seems probable that the idea of developing the NSV on a national scale was already in some activists' minds. ${ }^{2}$ Before the new organisation sought official recognition, and after discussion with the welfare adviser to the Nazi faction of the Berlin city council, Johannes Engel, it was decided to alter the name of the welfare association from NS-Wohlfahrt to NS-Volkswohlfahrt. ${ }^{3}$ The

1. HA, 14/262., p.156.

2. It certainly seems to have been in Kluge's mind at least, see HA, 14/262, p.172.

3. Ibid., p.156. 
addition of the emotive term 'Volk' seems to have been a very early indication of the future emphasis upon community responsibility for welfare; clearly the intention to induce the population to make contributions and undertake voluntary unpaid work for the NSV existed right from the start. ${ }^{1}$ Voluntary welfare workers would soon be recruited to carry out their duties according to the principle of 'selfless service'. ${ }^{2}$ Nazi welfare was intended to be designed to uphold the 'natural' order of the family, the neighbourhood, and the community of the people. ${ }^{3}$ Later criticisms of Weimar welfare arrangements by the NSV consistently centred round a passionate rejection of the Weimar system which, it was claimed, failed to promote a valuable sense of civic responsibility, either in those who dispensed welfare, or, consequently, in those who were on the receiving end of it. The NSV tirelessly emphasised the call to promote a healthy community dedicated to upholding collective, not individualistic, goals. The early decision to include the volkisch element within the name of the welfare association only signalled the future direction of NSV intentions. ${ }^{4}$ From 1933 the concept of the value of the individual would suffer a total eclipse in the writings, utterances and activities of the NSV. ${ }^{5}$

1. Ibid., P.160; pp.154-156.

2. Ibid., p.156.

3. Ibid.

4. Erich Hilgenfeldt, Idee der Nationalsozialistische Wohlfahrtspflege, Berlin 1937; Hermann Althaus, NS-Volkswohlfahrt, Berlin 1937.

5. Erich Hilgenfeldt, 'Die Volksgemeinschaft als Ausgangspunkt und Ziel im heutigen Deutschland', speech given to an international audience in London in 1936, in which the community is stressed as being of more importance than the individual, in Social Work and the Community, a contribution fnr the III International Conference on Social Work in London, 1936, Karlsruhe 1936. 
The new association gained the first stage in its official recognition as an independent agency after meetings with its founders, and local Party officials which resulted in the submission of a request for recognition to the Arbeitsgemeinschaft der Freien Wohlfahrt in the Wilmersdorf area. This request was written and signed by Erich Humbert, August Lang, Hildegard Loeser, and Herbert B bhme. Due acknowledgement arrived on the 25th September 1931, and official recognition was granted on the 19th December 1931. The next stage, which turned out to be protracted, would involve a request to become a registered Verein. At about the same time, the end of 1931, the Gau consultant of the Communal Policy Department, Herbert Treff, became aware of the existence of the new organisation. ${ }^{l}$ Treff was also the business manager of the NSDAP faction of the Berlin city council. He willingly gave his support in promoting the cause of a new welfare association, and became involved in seeing that all party members who were either already participating in welfare activities, or interested in such matters, got to know about the existence of the NS-Volkswohlfahrt. ${ }^{2}$ This interest which was shown in the NSV by the Berlin section of Kompola seems to have been a crucial factor in helping to establish it in the eyes of important Party officials in Berlin. To ensure that the new association developed as effectively as possible, its expansion across the Gau as a whole had to be coordinated. For this purpose, five officials were appointed who would act as advisers within each of the five districts of the Gau. The new officials were, Hans von Freyburg (North), Herbert Volz (East), Hermann Kluge (South), Waldemar Wensel (Mid.), and Erich

1. HA, $14 / 262$, p. 160 .

2. Ibid. 
Humbert (West). 1

With its basic internal organisation complete, the NSV now required to be registered as an official organisation to enable it to conduct its activities among the public at large. It would not, however, be Treff, who would lead the new organisation as its president, though it seems that he had wished to do so; as a well-known Nazi he had to step aside when it was decided that a less prominent character would have to be found before the application to be registered could be made. While the officials in Gau Gross-Berlin felt it necessary to draw attention away from the very close connection between the NSDAP and the NS-Volkswohlfahrt, there seems to have been, at this time, no real danger that the NS-Volkswohlfahrt would be unable to obtain official approval. ${ }^{2}$ It was only after many meetings in the Gauhaus in Hedemanstrasse, within the offices of the Communal Policy Department, and after one especially difficult and drawn out discussion between Treff and the other officials, that an acceptable document was drawn up which set out the aims of the new NSV. The name of the new president was Hermann Kluge though the period of his stay was short indeed, only lasting eleven months; his subsequent career was destined to remain outside the NSV. ${ }^{3}$ The document which had been drawn up was presented for authorisation and in April 1932, the NS-Volkswohlfahrt was included in the Vereinsregister of the Berlin Tempelhof district and given the number 582 VR. ${ }^{4}$ The new NSV was now an officially recognised independent

1. Ibid.

2. Ibid., pp.160-162.

3. Ibid., p.188; Kluge continued to be a State official after 1933 and was Burgermeister in Gransee during the war. See Erich Hilgenfeldt file, Berlin Document Center.

4. HA, 14/262, p.162. 
association which had official permission to function within the Berlin area, which meant that it now had the opportunity to become closely involved within the provision of welfare in the city of Berlin.

The early spring of 1932 was a time of exhausting activity for the Nazis, and especially Hitler, who had agreed to stand as a candidate in the Presidential elections. Germany was blanketed by literally thousands of rallies, and the presidential campaign was organised by an enthusiastic Goebbels whose propaganda material was designed with every socio-economic group in mind. ${ }^{l}$ Hitler's failure to win on March 13th resulted in important changes in the policies and organistion of the Party itself. That period in the Party's history began which witnessed the revival of Strasser's power and influence. Consequently, Goebbels' own influence suffered an eclipse, and his aggressive strategy of 'pure propaganda' was abandoned. The Strasser emphasis once more prevailed, whereby a Nazi victory was conceived as being possible only through gradual effort, within the context of a general undermining of the social and economic structure of the Republic. Once more, organisational activity became a central issue, and Strasser's reforms were extensive and designed to 'tighten the administrative lines of control which had been allowed to fall loose during the spring'. ${ }^{2}$ There seems good reason to believe that the NSV in Berlin had everything to gain from this revival of Strasser's fortunes, for it now seemed likely that the safe haven of the Communal Policy Department might offer an ideal base for the further development of

1. Orlow, The History of the Nazi Party, 1919-1933, p.249.

2. Ibid., p.258. 
the new association. The Communal Policy Department was now incorporated into Main Department III of the Party's administrative structure. $^{1}$ Besides this department, Strasser set up departments for Interior, Educational and Public Health policies. At this time, officials of the Communal Policy Department and the NSV worked closely together on ambitious plans for the future organisation of Nazi welfare. ${ }^{2}$ One of the most influential and enthusiastic supporters of the NSV at this time was the new head of Hauptabteilung III in Berlin, Karl Spiewock. Not only did he supervise a 'massive array of offices which concerned themselves with virtually every aspect of governmental life', but Spiewock was also actively prepared to support the development of the new welfare association. 3 .

It was through Herbert Treff that Spiewock had first become aware of the NSV. Treff had made it known that various difficulties were hampering the activities of the infant organisation, not the least of which were lack of office space and a shortage of money. Spiewock showed himself willing to help, at least with the accommodation problem, and the first discussions between Kluge, the new NSV leader, and Spiewock, resulted in office space being made available. Not only this, but the NSV which at this time would be local only to Berlin, was given the assurance that by virtue of its connection with the Communal Policy Department, it would be officially included within the Main Department III. ${ }^{4}$ The office space which was now allocated to the NSV belonged to Main Department

1. Ibid., pp.274-275; HA, 14/262, pp.160-168.

2. Ibid., pp.160-171.

3. Ibid., pp.166-167; Orlow, The History of the Nazi Party: 1919-1933, p.275.

4. HA, 14/262, p.168. 
III, and though it was described as small, and extremely uncomfortable, no more that a Durchgangzimmer or small ante-room, the NSV was grateful for the use of this accommodation for three days in every week. Such a modest beginning also required that the NSV members provide their own writing materials, make use of a borrowed typewriter, and share a telephone. Heating too had to be provided by the new officials themselves, and the small office was manned only as existing full-time jobs allowed. In other words, the NSV was run at this time entirely by part-time officials. The main task of these new officials, a dozen in all at first, who were responsible for the ten Kreise of the Berlin area, was to find a suitable number of trainee social workers. ${ }^{l}$

It seems certain that Spiewock was as enthusiastic as Herbert Treff about the establishment of a comprehensive system of Party welfare, which it would fall entirely to the new organisation to dispense. The significance of such a development was that activities which had hitherto been the responsibility of the Nazi women's groups (now the NSF) would ultimately be taken over by the NSV, though a complete takeover of all Gau-organised welfare on a national level would, of course, have to wait upon an acknowledgement from Party headquarters. The new NSV lost no time in making a start on the exclusion of the NSF from the field of welfare. In the autumn of 1932, there was a determined attempt by the new NSV and Spiewock to discredit the work of the NSF, two members of which were prepared to support NSV allegations that work, with regard to the provision of welfare, was being carried out 'without any kind of system', neither was it 'unified', nor attempting to make full use of existing

1. Ibid., p.167. 
resources. ${ }^{1}$ The person who made these 'facts' known, was one Erna Silomon, a member of the Berlin NSF. She seems to have been at the centre of a plot, for such it was, to help the NSV to take over from the NSF women within (ultimately) the whole organisation and arrangements of Nazi welfare, at first in Berlin, and later throughout the Reich. On the basis of these criticisms, a meeting was held in the home of another NSF member, Ingeborg Altgelt, and it included Spiwock, Silomon, and Frau Eva von Schroeder. ${ }^{2}$ After many issues were discussed, it was agreed that in all future welfare measures, a consideration of the political significance of such work would have to be given stronger emphasis. A political dimension was therefore to be added to Nazi welfare. Indeed, it was recognised that welfare activity, as dispensed by the Nazis, should no longer be regarded simply as a remedy for social and economic misfortune. ${ }^{3}$ To be given emphasis was the idea of 'Socialism of the Deed' through the dispensing of effective welfare measures. Certainly this ersatz socialism would figure somewhat in NSV/WHW rhetoric into the mid-1930s. Essentially, from 1933, 'Socialism of the Deed' was meant to supplant socialism per se; the message was that the existence of a Nazified 'real' socialism would render unnecessary the continued existence of political parties who were dedicated to socialist principles. As far as the Nazis were concerned, within a future Nazi society, social welfare policies would be pursued which would render the claims of socialist idealists superfluous. While these trends only became generally apparent later, from 1933, it seems that they

1. Ibid., pp.170-171.

2. Ibid., no date was given for this meeting.

3. Ibid.; Eva von Schroeder is reported to have emphasised that social welfare must be understood to be a political task. 
were present in discussions about welfare policies right from the start. The strong desire to politicise social welfare took all future welfare arrangements effectively out of the hands of the women of the NSF, as the Berlin Gau leader of the NSF knew only too well. ${ }^{1}$ She, Frau Fikentscher, was forced to confront both Erna Silomon and Ingeborg Altgelt after the clandestine meeting; not surprisingly the two co-conspirators were asked to leave the Nazi Women's Organisation. From this point Ingeborg Altgelt would enjoy a successful career with the NSV, obtaining an important administrative post in Berlin; so also, it appears, did Erna Silomon, who was appointed to organise an NSV department in $1933 .^{2}$

At the beginning of December 1932, the NSV could claim 1,680 members within the Greater Berlin area. ${ }^{3}$ while the NSV would eventually come to tackle all the activities which came under the label of Party welfare, it is necessary to emphasise how rapidly they set about effecting the beginning of a transfer of the work which had previously been undertaken almost solely by the women's groups. From 'winter aid' (the provision of expanded help in winter months) to the organisation of children's holidays in the summer, the NSV proceeded

1. Ibid., p.17l; it certainly seems that von Schroeder was the instigator of this particular line. Her file in the Berlin Document Center reveals little with regard to her earlier activities before her work with the Berlin NSV. She obtained a post with the NSV in Berlin after 1933, in the department which dealt with personal requests.

2. Ibid., p.17l; pp.220-221; Silomon was appointed to be in charge of 'Heime und Kuchen' in Berlin in 1933, which department disappeared later. Altgelt was appointed to head 'Schriftsfuhrung und Geschaftsfuhrung' in Berlin at the end of May 1933. She remained with the NSV until about 1935 when for health reasons she resigned her position as an administrator in Berlin.

3. BA, NSD 30/3, NS-Volksdienst, Organ des Hauptamtes fUr Volkswohlfahrt, 'Die Entwicklung der NSV bis zu ihrer parteiamtlichen Anerkennung durch den Fuhrer', Berlin, January 1939, pp. 4-21. See also HA, 14/262, p.173. 
quickly to involve itself in making initial arrangements for the closest participation in existing independent welfare in the Berlin area. ${ }^{l}$ After the autumn débâcle, the NSV did an about-turn and began to attempt to cooperate more amicably with the NSF in a share-out of the welfare work in which the NSF has been closely involved. ${ }^{2}$ No doubt the NSV wished to adopt a more cautious approach and avoid a head-on confrontation which might jeopardise its own ambitious plans. By the beginning of December 1932, the organisational plan of the NSV had taken shape, but most importantly the leader, Kluge, was described as President at Reich level; the leader at the local Berlin level was one $\mathrm{Pg}$. Wolff. ${ }^{3}$ It is tempting to suggest that the later problems which the NSV would experience with the Party in Munich may have been caused by this premature 'appointment' of a Reich level leader for the NSV. It is sure that such a title was an entirely fantasy one, with no basis in reality. Certainly Kluge may have gone too far, and his 'national leadership' would come to an end in February, or early March, 1933. It may have been that Strasser had merely permitted such a move but that the uncertainty consequent on his resignation prevented any clear contradiction of it from the centre until things had settled down. 4

In the winter of 1932 the first NSV Winter Aid drive took place. An ambitious scheme was set in motion by NSV officials, and Eva von Schroeder, in particular. ${ }^{5}$ After permission had been

1. $H A, 14 / 262$, pp.173-175.

2. Ibid.

3. Ibid., p.172.

4. Ibid., p.188; Kluge seems to have been appointed at this time to work (as a State official) in the Verwaltungsbezirk Tempelhof.

5. Ibid., 'Die NS-Volkswohlfahrt e.V., hat im Einvernehmen mit der NSDAP zu einem NS-Winterhilfswerk', pp.180-188. 
obtained in November from Goebbels, the whole scheme took off. First of all, arrangements for the delivery and distribution of essential foodstuffs were made, with Eva von Schroeder taking a leading role in encouraging donations for the NSV drive. Letters were sent off to the owners of estates in the surrounding country areas, and the State Governers of Mecklenburg-Schwerin and Brandenburg, with a plea that any produce which could be spared should be sent to an NSV depot in Berlin. ${ }^{l}$ Such produce would then be sorted and distributed by the NSV for the sole purpose of alleviating the misery of Berliners who were increasingly suffering acute hardship. By this time, an average of 148 per thousand of the population were unemployed during that year. ${ }^{2}$ Requests for help for the NSV 'Winter Aid' drive were also sent off to Rust, Gauleiter of Hanover South, and Telchow, Gauleiter of Hanover East. Permission to have a street collection was also sought, and a letter was sent to the Berlin Police President's office. It contained the important reminder that the NSV would be giving valuable help by adding to the city of Berlin's own winter welfare provisions.

It was during this first NSV 'Winter Aid' drive that a large NSV canteen was set up in the Charlottenburg district of Berlin. It was hardly surprising, at the time of the collapse of the unemployment insurance system, that the NSV regarded the opening of a new soup kitchen, or canteen, which would be open to Nazis, and non-Nazis alike, as a 'significant political act'. ${ }^{3}$ This particular move on the part of the NSV was a sure sign that the new organisation would act without real cooperation with the NSF, which had itself

1. Ibid., p.181.

2. See page 17 this Chapter.

3. Ibid., p.183. 
been providing this type of welfare for some time. The new provision was set up in an old building in 22 Spandauerstrasse, (then a disused tram station or terminal), and from the outset it was designed to be used by all Berliners within the area. A keen effort was made to attract the inhabitants of this run-down area of the city, regardless of political persuasion. ${ }^{l}$ To this purpose, it was settled beforehand that all inflammatory speeches by Nazi sympathisers would be forbidden, and the SA were instructed to refrain from the baiting of political opponents on the premises, and presumably in the immediate area. A really big effort was to be made to provide a welfare measure for the use of hungry Berliners who would be encouraged to see how the Nazis could provide aid for all-comers, in a peaceful setting. ${ }^{2}$ This particular venture underlined the trend of a politically motivated policy for welfare by the NSV. The population of Berlin was to be the first to be exposed to the notion that Nazi measures within the area of welfare, could exist as a legitimate replacement for socialist, or communist, political aims and ideals. The spirit of this 1932 version of 'Socialism of the Deed' was a forerunner of that kind of actively propagandistic 'socialism' which would characterise, at first, the later NSV schemes. The NSV canteen, it is also clear, was intended to prove, by example, that the Nazis were more humane than their enemies had made out in the past. 3 Berliners who could steel themselves to put up with the decorations of the interior, such as portraits of prominent Nazis and huge swastika flags, would find that the NSV was capable of providing
1. Ibid., pp.181-184
2. Ibid.
3. Ibid. 
good, cheap nourishment. Above all, the NSV set out to show that they had the well-being of the Berlin people at heart, that their concern was for the poorer citizens and the working-class population as a whole, even if they had shown themselves to be supporters of the communists or the SPD. ${ }^{1}$ It was the officials of the Communal Policy Department, the NSV, and, indeed, Eva von Schroeder, who took a leading role in the formulation of this particular policy. Propaganda and welfare would, from this time on, become inextricably linked within the policies of the NSV. ${ }^{2}$

On the 15th December, a week after Strasser's resignation, it was announced from the Reichsleitung in Munich that no actual or ideological connection existed between the NSDAP and the organisation calling itself 'Nationalsozialistische Volkswohlfahrt' in Berlin. Furthermore, the NSV was ordered to remove the title 'Nationalsozialist' from its name at once. ${ }^{3}$ This was no less than a bombshell to the leaders of the new organisation; it was an especially bitter blow, given that the Winter Aid drive had been successful, and the NSV was growing almost daily more effective. Both Dr. Conti and Dr. Goebbels had been prepared to support the NSV. Conti had asked the NSV to involve itself further with the work of holidays for children, and the activities of the NSV's Winter Aid drive had been publicised in the pages of Der Angriff on October llth that year. However, this aggressive stance on the part of the NSDAP in Munich followed hard upon the resignation of Gregor Strasser, and had far more to do with that, given the close connection with Kompola

1. Ibid.

2. Ibid.

3. Ibid., p.178. 
and Main Department III, than with the growth and development of a new welfare measure. ${ }^{1}$ In addition, as suggested above, some notice may have been take of the activities of Kluge who, it seems, named himself 'national leader' for Nazi welfare at the beginning of December. Whatever the cause, this development promised to destroy the NSV, almost from the beginning. Though the NSV was offered the possibility of making an appeal with regard to the change in name, what really mattered was that a virtual prohibition on the activities of the NSV had been received from Munich. The Party had seen fit to publish a statement to the effect that no links existed between the new NSV and the Reichsleitung; the statement had been signed by Schwarz, Bouhler and the Chief Party Counsel, Frank. ${ }^{2}$ Such a statement would only be interpreted by Party officials as a total repudiation by the Party of this new welfare organisation. As Kluge and the other NSV officials knew only too well, it would be the kiss of death for the NSV, and any hopes that it might later become a nationally-based organisation would be doomed to failure. The aftermath of the Strasser resignation seemed to threaten an eclipse of all NSV plans for the future. All the hard work of the past few months would be utterly lost if the NSV were unable to reinstate its connections with the NSDAP. It was for this reason that Kluge and Eva von Schroeder made frantic appeals both to Dr. Frank and Reinhardt Neubert, the President of the Reich General Counsel of the Bar Association. ${ }^{3}$ It seems, however, to have been a personal meeting between Schwarz and Eva von Schroeder in Munich which resulted in the
1. Ibid., pp.178-179.
2. Ibid.
3. Ibid. 
lifting of the 'ban' on the NSV. Recently David Kramer has pointed to the crucial involvement of Magda Goebbels, and her part in the reinstatement of the NSV. However it seems more likely that her involvement, which was of relatively minor importance, occurred after the reinstatement, and not before. ${ }^{1}$ There seems every reason to believe that Eva von Schroeder, who took urgent action, managed to convince Schwarz, at least, that the NSV ought to be supported. However, von Schroeder was unable to convince Schwarz that the name of the new organisation ought to be fully restored. Thus the NSV had to be content with calling itself Volkswohlfahrt e.V., until May $1933 .^{2}$ Though the very serious setbacks of December had been quickly resolved, at the time of the Party's greatest triumph, in January 1933, the NSV was having to deal with several serious problems at the same time. For example, with the Nazi victory came the partial dissolution of Main Department III, and the loss of the connection with the Communal Policy Department. Spiewock seems to have lost all effective contact with the NSV at this time, and Kluge was asked to step down as NSV leader. ${ }^{3}$ An 'old fighter', Kluge may have come to be regarded as less than able to carry out his duties, given that he had been seriously wounded, both in the war and in an anti-Nazi skirmish during the twenties. However, it may also have been that he was now seen as a rash and ineffectual leader who had allowed himself to push the NSV prematurely into making a strong bid to take on the responsibility for setting up a nationally-based

1. Kramer, 'Das Fursorgesystem', p.185.

2. HA, 14/262, p.179.

3. Ibid., p.188, one of Kluge's few public appearances as leader of the Berlin-based NSV was to officiate at a Tombola stall in 1932 . 
organisation. ${ }^{l}$ Most importantly, it might have been feared that he would prove to be unable to tackle the most urgent problem of all, namely the necessity of building anew a really effective relationship with the Party in Munich. ${ }^{2}$ Until the Party officially recognised the primacy of the NSV in matters of welfare, a nationally-based organisation could not materialise. Following the lifting of the ban of December 1932, there would have to be a rapid creation of support from Party leaders themselves for the organisation. Without this, it is altogether likely that the NSV would have gone under during the early months of 1933. This fate was, however, avoided through the interest which was shown by Goebbels during the early part of $1933 .^{3}$

On the 28th of February, 1933, Goebbels gave formal recognition to the NSV when he decided to have published a statement that, 'the Volkswohfahrt e.V., is an essential part of all future social welfare measures and any welfare activity in Berlin is to be undertaken with the collaboration of this association'. ${ }^{4}$ It is not absolutely clear exactly how he came to this decision, notwithstanding his wife's interest in the organisation, knowing as she did Ingeborg Altgelt and Frau von Schroeder. Precisely what her possible role was in interesting him in the NSV is uncertain, but it seems more than likely that his real attention had been aroused in November 1932, at the time when the NSV had sought permission to organise a 'Winter

1. Ibid., 'Vorsitzender fur das Reich Pg.Kluge', p.172.

2. Ibid., p.188.

3. Ibid.; Goebbels' statement was published on the 28th February 1933.

4. Ibid. 
Aid' drive in Berlin during the winter of $1932 / 33 .{ }^{1}$ It may have beenat his attention was drawn to the importance of the propaganda aspect of the NSV's first Winter Aid. It may also have occurred to him that after January 1933, social welfare measures offered a potentially valuable means of helping to unite the nation behind the new leadership. The attraction of a propaganda measure which also raised large sums for the poor may have been regarded by him as a heaven-sent opportunity to see six or seven million unemployed safely through the first winter of the new leadership's rule and also function as a device to create a substantial number of grateful supporters for the new government. Geobbels had seen, at first hand, the reasonably effective measures of the first NSV Winter Aid drive which, more emphatically than some of the other Gaus' organised welfare measures, introduced a politically motivated element into aid for the hungry. But the NSV also had a uniquely powerful sense of the importance of propaganda, indeed a propagandistic view of the nature of social welfare in general, which was evident right from the start. $^{2}$ Subsequent developments during the early part of 1933 support the view that Goebbels had become strongly interested in using social welfare as a propaganda measure, with the NSV undertaking to organise a series of collections in the spring. This measure would show the NSV in its best light and may have hastened its official recognition which came on 3rd May 1933. A powerful ally had been found in Goebbels, and his support, freely given in February

1. Ibid., p.180. Der Angriff had published an 'Aufruf' for the NSV to obtain the use of halls and rooms for its 'Winter Aid' drive.

2. Ibid., pp.180-188;

BA, NSD 30/3, 'Die Entwicklung der NSV', in NS-Volksdienst, January 1939, pp.4-8. 
1933, was of utmost importance. While it is true that Magda Goebbels was honoured for her work and support for the NSV in 1942, when she was awarded an 'Honour Medal for German People's Welfare Care' (Ehrenzeichen fUr deutsche Volkspflege), a decoration which was granted through the Propaganda Ministry in the name of the Party, it is likely that her husband had assessed for himself the value of a Party Welfare Organisation which, through propaganda and welfare would win support for the new leadership's measures and plans. ${ }^{1}$

The appointment of a new leader for the NSV at the beginning of 1933 was preceded by many discussions in which Goebbels' deputy seems to have played a leading role. ${ }^{2}$ On the 14th of March 1933, the job was finally offered by Gorlitzer to the former Gauinspektor I of the Gau Gross-Berlin, Erich Hilgenfeldt. ${ }^{3}$ From this time on, until the end of the war, Hilgenfeldt acted as leader of the NSV. Born in Heinitz in the Saar region, he had served in the First World War and held posts $S_{n}$ ibefortore becoming a Party official. He had joined the Party in August 1928, and had been appointed a Kreisleiter in Berlin, before being appointed a Gauinspektor. From the start, Hilgenfeldt showed himself to be an efficient and enthusiastic administrator, and from the moment of his appointment, he set about putting into operation a series of measures which were designed to coordinate all NSV practices and systematize the organisational arrangements of the

1. BA,R55/103, list containing Frau Goebbels' name to be awarded an 'Ehrenzeichen fur deutsche Volkspflege', II class.

2. HA, $14 / 262$, p. 189 .

3. Ibid., p.189. See also BA,NS 37ii/1006, letter from Werner Reher, Reichshauptstellenleiter of the NSV, to all NSV leaders in the Gaus, giving instructions for the press guidelines for the 10 year celebrations of the existence of the NSV. Included was a short 'Lebenslauf' of Hilgenfeldt, 20th March 1942. 
Berlin-based welfare organisation. ${ }^{l}$ The personality and character of the new leader can best be described as hard-working, frequently ungenerous and sometimes ruthless. ${ }^{2}$ His colleagues especially Eva von Schroeder, had every reason to fear his ever vigilant, eagle-eyed attention to detail. 3 A well-padded frame, which gave the impression of a more easy-going character, somewhat concealed an obsessive, hard worker who did not balk at the prospect of furthering the cause of the NSV in the face of frank opposition from other powerful Nazi leaders who had cause to fear the encroachment of the NSV upon their own particular interests. ${ }^{4}$

The first NSV measure under Hilgenfeldt which occurred after the February announcement by Goebbels, and before official Party approval, took place from the 12th to the 2lst of April, 1933. Collections were held throughout the whole of Berlin under the title 'Hitler's Birthday Donation Fund' and, according to the NSV history, as many as 575,000 Berliners were helped by this measure. This figure took in a majority of the unemployed as well as the old, the poor and those who had suffered the loss of insurance benefits. 5

1. Kramer, 'Das Fursorgesystem', pp.184-187; HA, 14/262, pp.189-210.

2. BA,R55/103, 'Verleihung des Ehrenzeichens (Medaille) fur deutsche Volkspflege', 6th May 1939. Hilgenfeldt made much in 1942 of the granting of the Honour Medals for German People's Care and refused to accept von Schroeder's list of names for medals to be granted in the lst Class category; most especially, Kluge was mentioned by Hilgenfeldt as having only worked for the NSV for a very short time, and therefore didn't deserve such an honour. Much time and effort was spent on these discussions with a great deal of ill-will, on the part of Hilgenfeldt and von Schroeder, who disagreed quite violently at this time, i.e. in 1941-42.

3. Ibid.

4. BA,R36/1001, Spiewock to Hilgenfeldt, 'ZuschUsse der Stadt Berlin fUr die NSV' letter of 17 th May 1938.

5. HA, 14/262, pp. 203-210. 
A big effort was made to include all categories of the needy and there is no reason to doubt the claim that everyone who needed help received it, regardless of political or religious affiliations. ${ }^{1}$ Help came in the form of food vouchers or second-hand clothing, but not cash. The city of Berlin was made aware of the existence of the NSV for a second time on the lst of May, when a day-long action was arranged, and during which the sale of paper edelweiss flowers was undertaken throughout the city. The sale of paper facsimiles of the Fuhrer's favourite flower seems to have been undertaken with some care and thorough planning by Hilgenfeldt, who issued a long list of instructions to every Kreis. Every Ortsgruppe had to take 'at least thirteen' collection boxes, three thousand of which had been newly manufactured with red labels for this occasion. ${ }^{2}$ These were intended to be wielded 'throughout the day', by the members of the $\mathrm{HJ}$ and the BdM (Bund deutscher Mydel), no doubt to impart a vigorous impression, and Party officials were required to appear in their Party uniforms. By these means, maximum visibility was to be achieved during. this action which had the stamp of Goebbels' own personal supervision on it, with the Party making a show of its 'gentler' side, distributing artificial flowers for purchase through a Nazi welfare collection. Nevertheless there would be many in Berlin who had seen another, less agreeable, side to Nazi rule during the time, shortly before, when leading trade unionists had suffered the destruction of their offices and severe beatings from local units of the SA. ${ }^{3}$ However, on the lst of May, between the hours of $9 \mathrm{a} . \mathrm{m}$. and $7 \mathrm{p.m}$. , the $\mathrm{HJ}$ and the BdM between them used 900 of the

1. Ibid.

2. Ibid., p.208.

3. Mason, Sozialpolitik, pp.82-84. 
collecting boxes or tins, and Party officials took charge of the largest number, 1,966 in all. The NSF made a less impressive showing, with only 134 boxes taken up during the day. As many as 1,500,000 'flowers' were sold, each one costing ten Pfennigs. These actions seem to have been a success for Hilgenfeldt and for the NSV, and demonstrated the ability to carry through a propaganda measure which drew attention to the new leader's suitability for assuming control over a nationally-based organisation which would present its welfare measures within a propaganda-based scheme. The question remained however whether such 'success' would be similarly interpreted by the Party leadership, (and Hitler in particular) as a clear sign that the NSV was ready to take on the responsibility for a welfare organisation which would function throughout Germany, as an independent agency and in the name of the Party. A rapid decision was reached, which suggests that Goebbels had lost no time in putting forward the merits and advantages of the new welfare association which had been operating within his Gau. ${ }^{l}$ On the 3 rd of May permission was granted by Hitler at last, with the official statement that the NS-Volkswohlfahrt e.V., would be responsible for all questions of social welfare; it would exist as an organisation of the Party. ${ }^{2}$

It is clear that the new Nazi organisation, as the history of the NSV suggests, achieved a great deal in only a very short time,

1. HA, 14/262, p.210. As the History puts it, the work of the NSV had been acknowledged in Berlin but would it be similarly accepted at Reich level?

2. Ibid., p.21l. The document signed by Hitler reads: 'Die NS-Volkswohlfahrt e.V., wird hiermit als Organisation innerhalb der Partei fur das Reich anerkannt. Sie ist zustandig fur alle Fragen der Volkswohlfahrt und der Fursorge und hat ihren Sitz in Berlin. Berlin der 3. Mai 1933'. 
going from shared ante-room to official recognition, at Reich level, in only a few short months. The NSV could put behind it the worries and problems of the winter of $1932 / 3$, for it had found an efficient leader who had shown the ability to ingratiate himself with the powerful Gau leader of Berlin, Goebbels, who moreover had shown a willingness to give Hilgenfeldt his chance to show, in the early spring, what he could do, both as an organiser and as a welfare official who was sensitive to the dissemination of propaganda. The NSV celebration on 6th May in the Hotel Kaiserhof was a glittering affair, attended by Goebbels, his wife (who seems to have acted as a prominent organiser of the event), officials of the Party and several important dignitaries. A speech by the new NSV leader emphasised the achievements of the past few months, outlining the participation of the NSV in Berlin, and the numbers of the population who had been aided by the new welfare association. ${ }^{l}$ From the NSV offices, now in 9 Spandauer Strasse in Berlin, there issued forth a series of instructions about the organisational shape of the NSV, which went through several alterations both of shape, and personnel, before the final arrangements were worked out. ${ }^{2}$ The five main departments of the NSV were as follows:

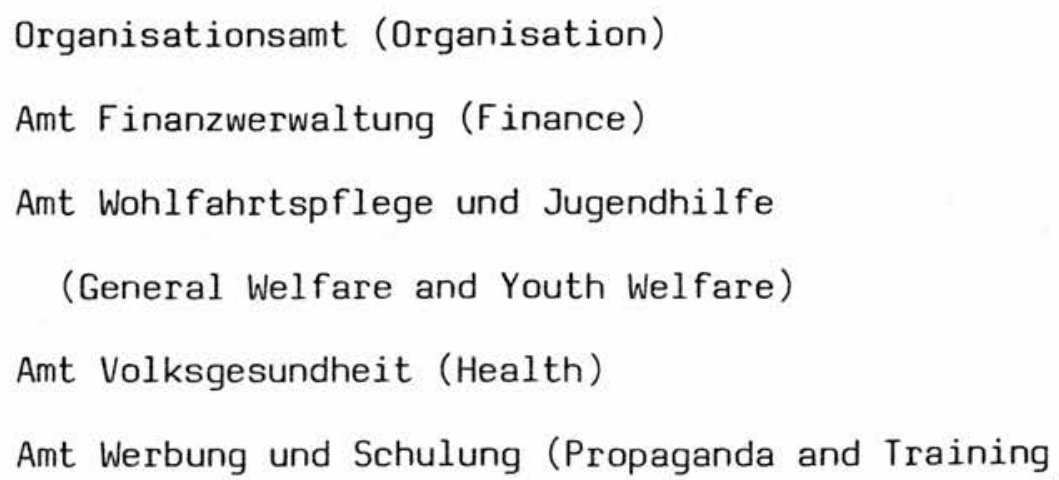

1. Ibid., pp.211-212.

2. HA, 14/262, 'Organisationsplan I and II', pp.248-251, and 'Organisatorische Aufbau', p.259.

3. Ibid., p.260; Ingeborg Altgelt, Wegweiser durch die NSV, Berlin 1935, pp.20-29. 
This organisational scheme remained virtually unchanged until the end of the war. The memberhship of the organisation began to build up rapidly, from a figure of 1,680 members within the Berlin area at the beginning of December 1932, to 112,000 in Berlin and elsewhere, at the end of December 1933.

NSV Membership 1933-1939:

$\begin{array}{crr}\text { December } & 1933 & 112,000 \\ \text { " } & 1934 & 3,721,000 \\ \text { " } & 1935 & 5,050,000 \\ \text { " } & 1936 & 6,418,000 \\ \text { " } & 1938 & 7,942,000 \\ \text { " } & 1939 & 10,403,000\end{array}$

In July 1933, the first organisational guidelines were set out in a long sixteen page document which gave information about ideological matters, as well as administrative arrangements. ${ }^{2}$ From the first it was clear that the NSV would emphasise the need to create a new sense of 'welfare consciousness', but also that it would at all times promote the needs of the community over those of the individual. The rationale, indeed the function, of Nazi welfare was to encourage the search for a new sense of individual 'strength' which could be put at the service of the community, above any consideration of the needs of the individual citizen. As Hilgenfeldt put it:

'The rights of the individual can never be greater than those of the community, nor can his duty to the community come second. The National Socialist State places the needs

1. Althaus, NS-Volkswohlfahrt, pp.42-43.

2. HA, 14/262, pp.234-248. 
of the community over those of the individual and will raise again the idea of selfless service for others'.

The constant re-iteration of this theme would occur in the speeches of Hilgenfeldt, in the written material of the NSV, and in the training schemes organised for NSV staff. From 1933, propaganda which fostered the sentiments outlined above was intertwined with social welfare as it was organised by the NSV in Germany; the call would go out from the NSV to participate actively in the creation of a society dedicated to the cooperative values of community Gemeinschaft, whose legitimacy would always be supported by pointing to the destructive tendencies of the 'selfish' and 'egotistical' values of the Weimar System. ${ }^{2}$

1. Ibid., Hilgenfeldt's speech of 30th June 1933, pp.233-234; BA, NSD 30/7, Ewiges Deutschland, Monatsschrift fur den deutschen Volksgenossen, October and March 1937.

2. Ibid., Hilgenfeldt's speech of 14th August to NSV members and workers, p.255; Hilgenfeldt, Idee. 


\section{CHAPTER 2}

THE INTEGRATION OF THE NSV WITHIN THE SYSTEM OF SOCIAL WELFARE

IN GERMANY

The NSV, and all Party welfare which had been developing from 1930 onwards, entered upon a field of activity which had previously been occupied by the agencies of the churches and other private charitable welfare associations on the one hand, and those of the state on the other. Far from introducing itself into an undeveloped system of social welfare, Party welfare, as it was now represented by the NSV, had to set about carving for itself a niche within a system which had undergone an important expansion between 1922 and 1924. A significant increase of state participation within the welfare system occurred in Weimar. Germany, when a new system for the care of children and young people was introduced at that time. While the agencies of the churches, the Protestant Innere Mission and the Catholic Caritas, would continue to operate fully, the state welfare system would experience both an enlargement of its activities, previously restricted to a fairly modest level of state-organised facilities, and an extension of its legal responsibilities to provide social welfare throughout Germany. ${ }^{l}$ When the Nazis came to power, the laws which underwrote the administration of welfare in Weimar Germany, were not simply set aside; on the contrary, the Reichsjugendwohlfahrtsgesetz of 1922 was retained, as were the statutory responsibilities of local government to support and to provide finance for the non-governmental welfare agencies. This particular arrangement worked in favour of the NSV right from the start, for as a frei (private) agency, it could look to the local

1. Friedlander and Myers, Child Welfare in Germany, pp.6-7. 
communities, the Gemeinden, for financial aid for its various measures such as, for example, youth care and child care, including the provision of kindergartens, welfare for mothers and children, holidays for children and special nourishment programmes including cheap school meals. ${ }^{l}$ Reasonably substantial sums were received by the NSV yearly in the form of a subsidy from the Gemeinden and the cities throughout the Reich. ${ }^{2}$ The levels of these sums were distributed according to the size of the community or city, although some at least of the smaller communities would arrange for the NSV subsidy to be paid in the form of rent-free premises being made available. ${ }^{3}$ It should be understood that the finances of the NSV and those of the NSV's Winterhilfswerk (WHW), operated independently of one another, with the WHW remaining financially self-sufficient but NSV continuing to receive state subsidies until the end of the war. ${ }^{4}$ Given the huge sums which were collected annually from the public for the WHW, it was unnecessary for the WHW to look elsewhere for finance in order to carry out its various measures; the NSV, on the other hand, very largely depended upon the sums collected through its membership dues, the state subsidies and, only rarely, upon collections from the public. There seems no reason to doubt, too, that Hilgenfeldt regarded the state subsidies as a most important

1. BA, R36/964, Rundfrage $\mathrm{Nr}$. III/5661/36, 'Beihilfen an die NSV in Rechnungsjahr 1936'; HA, Reel 13, Folder 259, 'NSV-Jugendhilfe' - 1924-1937.

2. BA, R36, Folder 964. This contains detailed information on NSV subsidies.

3. Ibid., Der OberbUrgermeister der Stadt SaarbrUcken, 'Beihilfen an die NSV', 18th January 1937.

4. BA, R36/962, state subsidies to NSV 'Zuschussleistung der NSV', 27 th February, 1937.

The subsidies were paid out according to the decrees of the Ministry of the Interior of 1.7.35 - MBliV.S.866; 5.11.35 and 7.12 .35 . 
source of revenue for the NSV and its various welfare activities. ${ }^{1}$

The organisational plan of the NSV underwent only minor changes of its organisational arrangements which had been set out during the summer of 1933, and which consisted of Organisation, Finances, General Welfare, Youth Welfare, Health and Training and Propaganda. 2 Some additions and changes were made however; in 1936, when a department Ernahrungshilfswerk was added; and in 1938, when a new sub-section Hilfswerk fUr deutsche bildende Kunst (aid for artists) was added to the office for Organisation in the Reichsleitung in Berlin. 3 In 1938, the organisational plan (not including the two new sections outlined above) was set out as follows:

I) Organisationsamt: (subdivided into)

IA Organisation

IB Winterhilfswerk

IC Statistik

ID Statistische Graphik

II) Amt Finanzverwaltung:

IIA NSV-F inanzen

IIB WHW-Finanzen

IIC Reichskartei

IID Finanzsonderaktion

IIE Heim und Grundstücksverwaltung

IIF Revision.

III) Wohlfahrtspflege u. Jugendhilfe:

II A Allgemeine Wohlfahrtspflege (einschl. Heim- und Anstaltsfragen)

1. BA, R36/962, Hilgenfeldt to the Stadtskommissar, Berlin, Dr. Lippert, letter of 7 th December 1936.

2. $H A, 14 / 262$, p. 259 .

3. BA, NS $37 \mathrm{ii} / 1001$, 'Anordnung $\mathrm{Nr} .22$ ', organisational outline, 14th July 1936. 
III) Wohlfahrtspflege u. Jugendhilfe: (continued)

IIIB Sonderfursorge

(Straffulligenfursorge, Trinker, Wanderer

und BahnhofsfUrsorge, FUrsorge fur Blinde, Schwerhbrige usw)

IIIC Familienhilfe und Wohnungsfursorge

(Einschl. MUtterholungsflege,

Kingertagestatten, Adoptionswesen).

IIID Jugendhilfe

IIIE Erholungspflege

IIIF Forschung, Archiv

IIIG Wohlfahrts-und FUrsorgerecht

IIIH Rechtsverwaltung und Versicherung

Angegliedertes Aufgabengebeit

Bittegesuche.

IIII Schwesternswesen.

IV) Gesundheit:

IVA Heilverschickung (einschl. T.B. Hilfswerk)

IVB Arztliche Leitung der Erholungs-Vershickung

IVC Ge:sundheitsfuhrung

IVD Gesundheitsfursorge

IVE Verwaltung

V) Werbung u. Schulung:

VA Propaganda

VB Presse

At the end of June 1938, the vertical organisational plan of the NSV was as follows:

1. Ibid., 'Aufbau des Hauptamtes fur Volkswohlfahrt in der Reichsleitung der NSDAP'. 


$\begin{aligned} 1938 & \text { - Altreich } & 1938 / 39 & \text { - Austria } \\ 445,967 & \text { Blocks } & 37,822 & \text { Blocks } \\ 83,600 & \text { Zellen } & 7,434 & \text { Zellen } \\ 21,861 & \text { Ortsgruppen } & 2,427 & \text { Ortsgruppen } \\ 678 & \text { Kreise } & 82 & \text { Kreise } \\ 32 & \text { Gaue } & 7 & \text { Gaue }\end{aligned}$

At the lowest level of the vertical organisation of the NSV existed the Blockwalter corps. Essentially in a voluntary position with no salary, the Blockwalter had the task of attending to all measures which had to be undertaken vis-a-vis daily announcements and the giving of advice to those living within his area. He maintained NSV activity at this lowest level and acted as the eyes and ears of the NSV with regard to informing upon those deemed to be anti-social or otherwise not strictly eligible for NSV or Wintershilfswerk aid. ${ }^{2}$ The numbers of NSV Blockwalter, according to numbers of households looked after by each individual Blockwalter were as follows:

\begin{tabular}{ccc}
\multicolumn{2}{c}{ Blockwalter } & Numbers of Households \\
\cline { 3 - 3 } & & 191 \\
1933 & 93,473 & 95 \\
1934 & 188,002 & 74 \\
1935 & 243,894 & 55 \\
1936 & 327,000 & 43 \\
1937 & 421,487 & (3)
\end{tabular}

In 1939, the numbers of NSV workers who were active within the

1. BA, NSD 30/3, NS-Volksdienst, January 1939, pp.16-17; the NSV Head Office was in Berlin.

2. Ibid., p.18.

3. Ibid.; see also Leistungen der Nationalsozialistische Wohlfahrtsplege, MUnchen/Berlin 1937, p.l. 
offices of the Gau, Kreis and Ort levels were as follows:

Numbers of NSV Staff - 1939

\section{\% Salaried \% Unsalaried}

$\begin{array}{lrrr}\text { Gau } & 6,292 & 97.9 & 2.1 \\ \text { Kreis } & 15,685 & 58.1 & 41.9 \\ \text { Ort } & 124,755 & 3.3 & 96.7\end{array}$

According to one NSV official, a daily average of three hours work was put in by voluntary staff throughout the year for the work of the NSV. However given that this particular figure was supplied by the NSV, in this case in NS-Volksdienst, it seems likely to have been a generous over-estimate, though some at least of the voluntary staff must have put in long evenings of hard work in the local NSV office, especially during the Winter Aid drives during the period from October to March. ${ }^{2}$ The new NSV also employed specialist staff, namely nurses, doctors, kindergarten nurses and other trained welfare staff and the numbers of these, from 1935 to 1941 , is shown as follows:

Numbers of NSV Salaried Staff

$\begin{array}{lllllll}1935 & 1936 & 1937 & 1938 & 1939 & 1940 & 1941\end{array}$

\section{Nurses \\ Kindergarten Staff Welfare Workers Youth Workers (Leaders) \\ Family Care Workers (Leaders) \\ Family Care Workers Women Doctors Other Specialist Staff}

\begin{tabular}{|c|c|c|c|c|}
\hline $\begin{array}{r}2,505 \\
3,192 \\
389 \\
149\end{array}$ & $\begin{array}{r}3,353 \\
5,586 \\
471 \\
195\end{array}$ & $\begin{array}{r}3,758 \\
11,432 \\
688 \\
222\end{array}$ & $\begin{array}{r}6,348 \\
17,095 \\
1,204 \\
308\end{array}$ & $\begin{array}{r}12,060 \\
30,642 \\
1,583 \\
455\end{array}$ \\
\hline 70 & 119 & 182 & 323 & 440 \\
\hline 72 & 170 & 143 & $\begin{array}{r}171 \\
2,288\end{array}$ & $\begin{array}{r}229 \\
3,486\end{array}$ \\
\hline 6,377 & 9,894 & 16,425 & 27,737 & 48,895 \\
\hline
\end{tabular}

3. BA, NS26/261, 'Leistungen der NSV', 'Aufkommen und Verwendung der

Mittel im Winterhilfswerk des deutschen Volkes', p.25.

Total

1. BA, NSD 30/3, NS-Volksdienst, January 1939, p.19.

2. BA, NS 37ii/1062, NSV Gau Sachsen, confidential reports, 'Tatigkeitsbericht' (331316), March 1935. 
Social welfare, in the form of support obtainable by virtue of unemployment or other loss of income for individuals, as it existed during the 1930s and later, was organised in Germany under a complicated system of rules which the Nazi takeover did nothing to simplify. There existed nine branches, with the NSV occupying that section which came under the heading Freie Wohlfahrt. The nine sections or branches of the social security system were as follows:

1) Sozialversicherung (Social Insurance)

2) Versorgung (War victims and military pensions and benefits)

3) Fursorge (Public Assistance)

4) Familienunterhalt (Soldiers' dependents' allowances Displaced families' allowances)

5) Unterstutzung (Benefits from DAF)

6) Freie Wohlfahrt (NSV and charitable agencies of Caritas and Innere Mission and other remaining private agencies)

7) Kinderbeihilfen (Children's Allowances)

8) Arbeitslosenhilfe (Unemployment Relief)

9) Arbeitsrechtliche Sicherung

(Employers' Liability Insurance)

It seems to have been possible for individuals to obtain several parallel benefits, so that income from state welfare would be able to meet most needs, under normal circumstances. This was because the complicated system did not allow any one branch of social security to provide fully sufficient cover. Most notable in this regard seems to have been the section, Sozialversicherung, which left a majority of older citizens (Sozialrentner) with pensions which were barely

1. Germany, Basic^ and Annexe VIII, 'Social Security'. 
sufficient to meet the most basic of requirements. ${ }^{1}$ However, some of those in receipt of Sozialversicherung were eligible to receive benefits from Versorgung as well, and were thus able to exist above the poverty line because of payments from two separate sections of the welfare system. To these types of social welfare payment for citizens were added, in winter time, the benefits in kind which came from the NSV's Winter Aid scheme, if these were deemed to be necessary. The WHW would continue to pay out to lower paid workers and to pensioners a supplement in kind, either of food or fuel, or both, until the end of the war. ${ }^{2}$

The welfare of both the NSV and its Winter Aid scheme was intended from the beginning to function as a supplement to the existing state measures. The state would continue to pay out cash benefits to welfare cases according to existing legal requirements, so that NSV donations whether in the form of supplements for payment of rent, gas and electricity accounts, (some of the few monetary benefits), or in the form of help in kind, were usually given out when all other possibilities had been exhausted. This aspect of NSV welfare had a 'last resort' quality about it, given that the NSV stepped in only after all the other sections of the welfare system had been explored. ${ }^{3}$ However, NSV welfare did not only consist of these types of donation to the needy, for many of its other measures included an emphasis upon ideological training which was generously provided within the design of the facilities for welfare for mothers

1. Ibid.

2. Ibid.; see Chapter Three.

3. BA, NSD 30/34, Winterhilfswerk des deutschen Volkes, Allgemeine Arbeitsanweisung 1936/37, MUnchen 1937, 'Grundlage der Betreuung', p.21. 
and infants, and for the youth of the nation. ${ }^{l}$ In other words, ideological indoctrination was freely distributed, while the more familiar welfare benefits were not. Care was taken to see that NSV aid was not given out in advance of that which might be given by the state or the churches. ${ }^{2}$

Elements both of miserliness and of generosity characterised NSV welfare measures depending upon whether they were part of the schemes for donations to individuals or whether they were part of ideologically motivated provisions for social welfare, such as youth welfare, child welfare and training schemes for young mothers. ${ }^{3}$ Inevitably, NSV facilities for kindergartens, and youth welfare in general, came to act as rivals to the existing state provisions, which strictly speaking, they had no right to do. ${ }^{4}$ The NSV was supposed to fit in with the state arrangements, and not to set up in opposition to them, though no clear guidelines existed as to how it might be able to achieve this particular goal. ${ }^{5}$ However, neither the state provisions, nor those of the churches, would suffer a serious restriction of their services for some time to come, for it would take time for the NSV to build up its own organisational framework and levels of staff. For example, the NSV in Berlin in 1936, still had only three kindergartens, though several more were planned for

1. BA, NSD 30/4a, NS-Volksdienst, December 1943, 'Zehn Jahre Hilfswerk Mutter u. Kind', p.l6l.

2. Kurt Mennecke, Ein westdeutscher NSV-Kreis. Seine Entstehung und sein Menschengefuge vom 15. September 1933 bis zum 30. November 1934, Koln 1936, pp.72-94.

3. See Chapter Four.

4. BA, R36/962, Spiewock to Dr. Lippert, letter of 30th December 1936.

5. BA, R36/962 'Erlass v. 12. September 1938, RMBL.IV,S,154'. 
the city at this time. ${ }^{1}$ This is not to say that the NSV did not have an important impact on the provisions of social welfare, On the contrary, for the church agencies would increasingly find that they would be required to provide aid for those who had been rejected by the Party's welfare organisation on the basis of criteria stigmatizing 'asocial' or 'biologically inferior' individuals or families. NSV officials were required to make careful investigations of welfare claimants who were required to be both 'hereditarily healthy' and 'socially worthy', before aid could be given. ${ }^{2}$ These requirements also constrained the work of state officials, and it seems to have been an area of possible friction, leading state officials very frequently felt it to be advisable to make pointed reference to their own application of these conditions in the light of an NSV tendency to criticise the state's 'laxity' whenever possible. 3

It was for these reasons that the character of social welfare in Germany would soon begin to alter, with the Party and state agencies creaming off those who could be described as the less troublesome cases for themselves. The resources of the regime would be spent on those who were regarded as 'worthy' of aid. Those who were regarded as 'unworthy', and therefore liable to act as a drain on precious scarce resources, would find that no help would be forthcoming for the duration of the Third Reich. ${ }^{4}$ Nevertheless, the

1. BA, R36/962, Hilgenfeldt to Dr. Lippert, 'Einrichtung der NSV in Berlin', 7th December 1936. The NSV tended to assume control over existing kindergartens and nurseries first before setting up its own arrangements.

2. BA, R36/962, Spiewock to Stadtpräsident der Reichshauptstadt Berlin, letter of 20 th January 1937.

3. Ibid.

4. The NSV strictly applied these rulings, see BA, NS 37ii/1062, Gau Sachsen, 'Stimmungsbericht', March 1935. 
NSV functioned more ruthlessly in this respect than did the state officials, whose legal responsibilities acted to restrain (albeit in a marginal way) this particular aspect of Nazi welfare. ${ }^{l}$ Inevitably then, an element of penalisation and preference existed in the state provisions for welfare after 1933, as well as within those of the Party. Certain types of socially irresponsible behaviour, now officially labelled 'asocial' and thereby 'unworthy' of support from the Nazi regime, allowed that individuals whose behaviour came within this unacceptable range would find that their benefits from state welfare could be cut, or withdrawn altogether. Within this category were, especially, the unrepentantly 'work-shy', and it was they who found that most of their welfare support was cut off. ${ }^{2}$ State welfare officials, however, were keenly aware of the difficulties involved in applying the 'asocial' category to fathers of families, for there existed no effective measures whereby the wives, and the 'hereditarily valuable' children of those so labelled could be fully protected from a withdrawal of a major part of economic aid from the state. Thus to a degree an anomaly was created within the state welfare system which allowed that some 'hereditary valuable' children, whose protection the Nazi support systems were meant to secure, would be denied essential welfare aid which the state itself had a duty to provide. These developments seem to have been viewed as entirely unwelcome by some officials who had, in one exceptionally difficult case, no option but to offer to restore welfare payments to

1. BA, R36/962, see correspondence of December 1936 regarding the interference of the NSV in welfare cases of the state.

2. Heavy drinkers and childbeaters especially came into this category; BA,R36/962, Stadtoberinspehtor, to Dr. Lippert on the case of Hellmuth Hohne, report of lith December 1936. 
a wife and children on condition that they ceased to live in the family home. ${ }^{l}$ If repeated attempts to help those certified medically unfit for heavy work to accept more suitable employment had failed, and the patience of the welfare officials had become exhausted, the necessary application of the 'asocial' category only further complicated the work of those who had to deal with these and similar cases. The penalising of a husband might, in some cases at least, mean the long-term dependence of his wife and children upon state welfare benefits. ${ }^{2}$ However, the threat of such a penalty must have acted to encourage many to take on work which they otherwise would have considered to be undesirable. As one study has pointed out, many were forced into accepting work which was both upalatable and back-breaking, and at rates of pay which were lower than welfare benefits; there was little choice but to accept such work, given the knowledge that no benefits would be forthcoming when repeated refusals to do so would result in the 'asocial' label being applied. 3 It must be remembered that repeated refusals to take up a job also involved the loss of WHW aid, for the employment office withdrew the necessary documents which entitled the unemployed to benefit in kind from the NSV's Winter Aid scheme. ${ }^{4}$

1. Ibid. Discussions on the case of $\mathrm{Vg}$. Hellmuth Hohne, Berlin, 30th December 1936. Ibid., Spiewock to Dr. Lippert, letter of 30th December 1936. It seems that welfare in kind from the NSV would still be available for wives and children however.

2. Ibid.; The repeated attempts to find work for one case at least shows that the 'asocial' category was not necessarily swiftly applied by state officials. In the case of Hohne, welfare officials were prepared to make several attempts to help before labelling him as 'chronically work-shy'.

3. Ian Kershaw, 'How Effective was Nazi Propaganda?', in Nazi Propaganda, D. Welch (ed.), London 1983, p.189.

4. BA, NSD 30/34, Allgemeine Argeitsanweisung (2), p.21. 
Other problems were created for the state officials too, by the use of the 'asocial' designation through the tendency of the NSV to interfere in individual welfare cases when they felt inclined to do so. ${ }^{1}$ It seems to have been possible for the NSV to put forward a case for withdrawing welfare support or, uncharacteristically, for asking for the removal of individuals from the 'asocial' category, when they felt that it was justified. ${ }^{2}$ Such interference was viewed with extreme irritation by leading state officials who were forced to make a reasoned argument to the NSV about the necessity of keeping out of the affairs of the state welfare offices. ${ }^{3}$ Such requests to the NSV to stay out of the state sphere were often accompanied by a firmly stated resumé of the impeccable Nazi viewpoint of the state welfare officials. ${ }^{4}$ It certainly seems that it was necessary frequently to 'remind' Hilgenfeldt of this. Such interference may have been doubly unwelcome, for the NSV, as an independent agency, had no legal responsibility to pay out cash welfare benefits to individual recipients, nor did it; neither was it entitled in law to encroach upon these responsibilities, without prior agreements having been reached. It was hardly surprising that officials in Berlin were not slow to make complaints of such interference to their superiors in the Deutscher Gemeindetag. 5

1. BA,R36/962, Dr. Lippert to Hilgenfeldt, on five individual cases in which the NSV had interfered, letter of 4th February 1937.

2. BA, R36/962, NSV to Dr. Lippert, letter of 6th November 1936.

3. BA, R36/962, Dr. Lippert to Hilgenfeldt, letter of 4th February 1937.

4. Ibid.

5. BA, R36/962, 'Schreiben des Hauptamtes fur Volkswohlfahrt vom 6.11 und 10.12.1936': copies of NSV letters were sent to the President of the DGT and to Schluter, of the DGT, amongst others. 
Almost from the beginning, the NSV experienced varying degrees of difficulty in achieving a trouble-free working relationship with the state welfare offices, in order to gain a substantial measure of cooperation for its own welfare facilities. Leading state officials were justifiably concerned about the thrust of NSV policy, which increasingly demonstrated the intention to alter, in its own favour, the balance between state and Party welfare. The regime, as it existed, could offer no solution to these problems for it would not, indeed could not, provide a set of clear guidelines for the clarification of the relations between Party and state, given the political developments of $1934 .^{1}$ The Law for Ensuring the Unity of Party and State of lst December 1933, created not the indissolvable link between Party and state which it promised, but it worked to favour the one, the state, over the other, the Party. ${ }^{2}$ Indeed the prime function of this law was to end the Party's revolutionary thrust, and to aid the consolidation of the internal political stability of the regime, something which was achieved in the summer of $1934 .^{3}$ The system of social welfare could not remain apart from these political developments, for the innumerable conflict-laden but shifting relationships of power within the political sphere were mirrored, albeit on a reduced level, in the function and operation of state and Party welfare. This would be most clearly demonstrated in the numerous struggles over the administrative arrangements for youth welfare from 1934. Both state and NSV officials indulged, until the

1. Martin Broszat, The Hitler State: The Foundation and Development of the Internal Structure of the Third Reich, New York 1981, pp.204-215.

2. Ibid., p.209; Jane Caplan, 'The Civil Servant in the Third Reich', D.Phil thesis Oxford 1974, p.92.

3. Broszat, The Hitler State, p.209. 
end of the war, in a work-creating tug-of-war over the correct balance between state and Party youth welfare facilities. ${ }^{1}$ A long, barely concealed struggle surfaced time and time again, pulling in, on their respective sides the leading officials of the Party and the state. ${ }^{2}$ Bormann, Hess, Frick, Fiehler and others all made contributions to the discussions of such issues, but without finding a solution to the central problem of jurisdictional squabbling between the NSV and the state officials. ${ }^{3}$ Agreements which were concluded between the NSV and the DGT seem to have been little more than a formal exercise which the two signatories were obliged to act out. Little of real substance was contained in the expressions of Hilgenfeldt that,

'the work of the NSV does not intend either in Berlin or in the Reich to interfere in, or to weaken in any way, the essential state welfare arrangements'.

These statements did nothing to calm the fears of the leading officials in Berlin, who expressed concern over developments during 1936, when it had become clear that the NSV intended to increase rapidly its involvement in the provision of kindergartens in the city by offering rival facilities; denials on the part of the NSV could not hide the fact that such was the case. ${ }^{5}$ Much bitterness was generated by the knowledge that NSV subsidies, paid by the state, were in effect, being used to further the development of facilities

1. BA, NS/25, Folder 1233; see Chapters Five and Seven.

2. Ibid.

3. BA, NS 25/1233, 'Vereinbarung zwischen RMDI, und Stellvertreter des FUhrers über NSV-Jugendhilfe', n.d.

4. BA, R36/962, Hilgenfeldt to Dr. Lippert, letter of 7th December 1936.

5. Ibid.; see Chapter Six. 
which would ultimately rival those of the state. Perhaps it was this specific situation, namely, that the state was obliged to pay for the dubious pleasure of seeing its facilities made redundant, which made it unlikely that any agreement could be viewed by state officials as workable. ${ }^{l}$ For this reason alone, apart from the complicated issue of state and Party relations, no written agreement on behalf of the NSV and the DGT could add to the search for a peaceful co-existence between state and Party welfare. ${ }^{2}$ At the beginning of 1937, a leading state official wrote of a possible NSV takeover of state arrangements,

'with regard to the NSV whose welfare work is founded on freedom to provide, not on a legal basis, its taking over of public welfare is unthinkable'.

Understandably, the NSV had far fewer problems to face with regard to the assumption of control over the plethora of existing private, non-denominational agencies. During the summer of 1933, it set about a rapid consolidation of its position as the leading agency when a majority of the private agencies were forced to go into liqidation or to be incorporated into the NSV. ${ }^{4}$ Control over existing Party welfare was established, and numerous special agreements were made between the NSV and the NSF, the DAF, the HJ, the German Red Cross, the Catholic Caritas and the Protestant Innere Mission. The NSV was quick to outline its responsibilities vis-a-vis the other Party organisations and the churches, none of whom

1. BA, R36/962, Spiewock to the Stadtprasident, 20th January 1937.

2. BA, NS25, Folder 1233 .

3. BA, R36/962, report, 'Ubertragung von Aufgaben der Gemeinden an die NSV', 29th January 1937.

4. HA, 14/262, pp.226-227. 
presented themselves as a serious threat to NSV plans for the future. ${ }^{1}$ The developments meant that the women's organisation, the NSF, virtually ceased to be involved in social welfare on a significant level, though its members would be expected to provide help for NSV measures and they would be urged to make themselves available for participation in NSV work when the occasion arose. ${ }^{2}$ It does seem however that NSV and NSF cooperation did not always work smoothly and served only to hamper the work of welfare in one area such as Westfalen-Nord. ${ }^{3}$ The NSF would be allowed, nevertheless, to organise the arrangements for domestic training courses for women through its Reichsmutterdienst operation. This particular facility would be run by the NSF's Deutsches Frauenwerk. ${ }^{4}$ However, the welfare work of the Party would be organised by Hilgenfeldt, with the NSV's own Gauamtsleiter corps being responsible for all local Party work undertaken within each Gau area.

By the spring of 1934, the NSV, which was now operating

1. BA, NS 37ii/105., agreements over the employment of women in the work of the NSV for those undertaking 'Labour Service', 5th August 1937; NS 22/748, 'Vereinbarung', NSV/Red Cross, 18th December 1937; NS 37ii/1016, 'Vereinbarung', NSV Innere Mission, 22nd March 1938; NS 37ii/1015, 'Vereinbarung', NSV/Caritas, 22nd March 1938.

2. BA, NS 37ii/1062, Gau Sachsen, 'Stimmungsbericht'(331215), 5th May 1935; the NSF usually helped in the street collections, such as selling badges and other small items.

3. Ibid.; it seems that complications arose over the sale of NSV badges at this time (May 1935) allowing the entire action to be counted as a failure. See also a study of the Gau WestfalenNord with regard to NSV and NSF cooperation in which this was not altogether effective. Adelheid Grafin zu Castell RUdenhausen, 'Nicht mitzuleiden, mitzukämpfen sind wir da!' 'NSV im Gau Westfalen-Nord', in Die Reihen fast geschlossen, QReulecke, J. Peukert (hrsq.), Wuppertal, 1981, pp.230-234.

4. Gertrud Scholtz-Klink, 'Mütterschulung in Deutschland', in Social Work in the Community: a Contribution for the III International Conference on Social Work, London, 1936, Karlsruhe 1936. 
throughout Gau, Kreis and Ort levels, (with offices at each level within every Gau), had assumed a virtual supremacy over the independent or private welfare sector. This was shown when it took over the presidency in 1934 of an Arbeitsgemeinshaft der Freien Wohlfahrt, and this leading position would be held until the end of the war. As well as the NSV, this group included the few remaining private agencies, namely, those of the churches and the Red Cross. It would be this collection of independent agencies which would form the non-governmental welfare sector until $1945 .^{1}$ All of these agencies would receive support from the state, though the NSV (and in some special cases the $\mathrm{HJ}$ ), would take the largest share of available resources. $^{2}$

By the end of December 1939, the NSV had 12,360,000 members in the area of the Greater German Reich, and by the end of 1942, this figure had risen to $16,878,402$. This particular figure breaks down as follows:

$\begin{array}{lr}\text { NSV members } & \text { December } 1942 \\ \text { Altreich } & 14,407,642 \\ \text { Ostmark } & 1,618,576 \\ \text { Sudetenland } & 707,451 \\ \text { Wartheland } & 144,733\end{array}$

It must be emphasised that these gross figures, by themselves, reveal nothing of the continuous efforts of the NSV staff to recruit new

1. HA, 14/262, pp.226-227.

2. $B A, R 36 / 964$, state subsidies to private welfare see 'Aufwendungen fur Vereine auf dem Gebeite der Wohlfahrt, Titel III, Jugendpflege, 1936'. pp.282-286.

3. BA, NS 37ii/1059, NSV statistics, 'Beim Hauptamt, Berlin, erfasste Mitglieder im Verhaltnis zu den Einwohnern, Ende Dezember 1942'. 
members for the organisation. It is necessary therefore to look at the individual Gau reports which were sent to Berlin for Hilgenfeldt's attention, in order to discover how these figures were achieved. These reports, completed on a monthly basis, reveal the heroic efforts of the local staff, not only in persuading more and more to join, but in keeping the numbers steady once the decision to join the NSV had been made. ${ }^{1}$ The Gau reports of Saxony show clearly that the NSV had many problems to face. Lack of support from the Catholic population in certain areas of the Gau was matched by a definite reluctance on the part of the low paid non-Catholic sections of the population to join. ${ }^{2}$ In Sachsen at the end of May 1935, the numbers of NSV members were $358,922,{ }^{\circ}, 6.9 \%$ of the population within the Gau. By the end of October 1939, this figure had risen to 880,544 , or $16.9 \% .^{3}$ Even though the improvement in these figures looks impressive it gives no indication of the true nature of NSV support in the area during 1935 and 1936. Even though membership fees were reduced by half from one mark to fifty Pfennigs per month for those who could not easily pay the whole amount, Gau officials of the NSV local office readily admitted that popularity had reached rock bottom in 1935 where, in certain areas of the Gau, income levels promised to remain low for some time to come. ${ }^{4}$

The numerous local difficulties which were being experienced in the Ortsgruppen of Sachsen, show how complicated the task of gaining

1. BA, NS 37ii/1062, Gau Sachsen 'Tutigskeitsbericht und Stimmungsbericht' (331271), May 1935.

2. Ibid., Gau Sachsen, 'Tutigskeitsbericht-Abtlg. Organisation' (331205), May 1935, p.2.

3. BA, NS 37ii/1059, NSV statistics, 'Ende Dezember 1939'.

4. BA, NS 37ii/1062, Gau Sachsen, 'Stimmungsbericht' (331271), May 1935, p. 2 . 
support for the NSV was at the beginning with membership drives having to be cancelled on account of the mood of the population in certain areas such as Reumten-GrUn and HammerbrUcke especially, NSV officals were reluctantly forced to conclude that membership drives were out of the question in these areas, 'for the present'. ' During 1935, the majority of those in employment were having to work shorter hours, and were therefore having to manage on much reduced incomes because of this. ${ }^{2}$ NSV officials reported that if the work situation in these areas did not quickly improve, then, it would be utterly impossible to talk of a successful membership drive for some time to come $^{3}$. As one official put it:

'I have at the moment the greatest difficulty in persuading some NSV members not to quit the organisation altogether'.

The gross membership figures of the NSV cannot show how local difficulties were hampering the work of officials in many areas of Sachsen, and no doubt elsewhere in Germany. During 1935, NSV staff were deeply concerned about the low levels of income in areas such as the Ortsgruppe Muldenberg, where many workers were not only working shortened hours, but were also quite unsure of how long such employment would continue. For this reason one worker in this area had remarked angrily to the local NSV official that:

'when we can get a secure and a better income, then we will gladly join the NSV'.

1. Ibid., Gau Sachsen, 'Stimmungs?bericht' (331273), May 1935, p.3.

2. Ibid., p.l.

3. Ibid., p.3.

4. Ibid.

5. Ibid., p.4. 
The example of Sachsen shows that low income on the one hand, and willingness to join the NSV on the other, sometimes operated in a mutually exclusive manner.

Added to these worries, were the difficulties which the NSV was experiencing over the complete failure to gain popularity with the Catholic populations of the Kreise Bautzen and Kamenz in the north-eastern part of Sachsen, and these difficulties were perhaps made the more urgent by the reports of the activities of the priests in these areas who had been encouraging people to join the Caritas agency, and to ignore the NSV. ${ }^{l}$ This meant that the NSV had to deal with problems which arose out of Caritas activities in the poorer Catholic sections of the Gau, where support for the NSV was already weak, as well as within the poorer non-Catholic areas elsewhere. In Protestant areas there was little real support not only because of economic and other factors, but because of the lack of interest which poorer people at this time showed towards the Party's own welfare organisation, and it seems that the poorer sections of the population had not themselves identified with the aims of the NSV? Given that these several problems may also have occurred, to a greater or lesser degree, in other Gaus as well, it must be concluded that a significant part of the work of the local NSV offices before the war was taken up with membership drives for the NSV, rather than with the work of welfare as such. The Gau reports of Sachsen certainly give such an impression. ${ }^{3}$ However, even allowing for the successes of the membership drives, in many cases membership itself only signified

1. BA, NS 37ii/1062, Gau Sachsen, 'THtigskeitsbericht' (331205), May 1935, p.2.

2. Ibid.; see also 'Stimmungsbericht' (331333), January 1935.

3. Ibid. 
the desire to be left in peace to get on with the normal daily round as far as that was possible. ${ }^{l}$ It is sure that a large passive membership existed which meant that an over-worked minority undertook the voluntary duties of Party welfare work. This was something the officials in Sachsen also drew attention to in $1935 .^{2}$ But the NSV seems not to have been unduly concerned about this matter, no doubt such desultory support was seen to be capable of improvement. It might even have been seen as a valuable 'first step' which itself promised a greater degree of commitment by virtue of frequent 'exposure' to the valuable practical work of the organisation. Many, it was hoped, would come to realise how important this activity was and thereby make a greater commitment to the organisation. The zeal with which local staff went about recruiting for the NSV suggests perhaps that this goal was one reason for the countless drives which were put into operation, as well as the desire to compete with other Gaus' membership levels. Indeed Sachsen would eventually emerge as one of the 'best' Gaus in terms of its membership levels in $1942 .{ }^{3}$ This is to say by the end of 1942 , with a memberhip of $24.7 \%$, Sachsen had succeeded in becoming second among the Gaus with regard to its membership levels, so that the tireless efforts of the NSV Gau staff can be seen to have been entirely successful. The five leading Gaus in terms of membership levels of the NSV in 1942 were as follows:

1. Ibid.

2. BA, NS 37ii/1062, Gau Sachsen 'THtigskeitsbericht' (331316) May 1935, p.4, 'We must ensure that all this work is shouldered by many more than at present'.

3. BA, NS 37ii/1059, NSV statistics, 'Ende Dezember 1942'. 


$\begin{array}{lrr}\text { DUsseldorf } & 626,782 & 28.3 \\ \text { Sachsen } & 1,270,189 & 24.7 \\ \text { Hessen-Nassau } & 719,393 & 23.7 \\ \text { Berlin } & 976,295 & 23.5 \\ \text { K8ln-Aachen } & 511,450 & 21.7\end{array}$

The same Gaus, with regard to the relationship between numbers of households, and the percentage of NSV members by household, is given as follows:

Numbers of households, 1942

DUsseldorf 722,880

Hessen-Nassau 930,851

Sachsen

KBln-Aachen

Berlin
$\%$ NSV membership by household

86.7

77.2

72.0

71.3

60.8

From the above figures it can be seen that by 1942 in the Altreich, no Gau exceeded 30\% of it population taking up NSV membership. The Gau with the largest percentage of NSV, was DUsseldorf (28.3\%), and Schleswig-Holstein which reported a figure of $13.3 \%$ was the one with the lowest membership levels among the Gaus at that time (1942). ${ }^{3}$ It certainly seems that an organisation with a membership of just under $30 \%$ in the best areas (13\% in the least well represented ones) could be forgiven for claiming, as it did, that it was the largest welfare

\section{Ibid.}

2. Ibid., NSV statistics, 'Aufnahme-Erklärungen im Ver_haltnis zu den Haushaltungen, Ende Dezember 1942'.

3. BA, NS 37ii, Folder 1059 
organisation in the world. However, given that many factors influenced the decision to join the NSV, most notable of these being level of income and the ability to pay the membership dues, it can be seen that the NSV would only be really successful where economic and other factors, such as religious affiliation, did not seriously come to hinder the success of the numerous membership drives which had become a familiar feature in every Gau from 1935. Recognition of the need to provide oneself with some form of protective colouring within Nazi society was an important motivating factor in the decision to join, this may have helped to keep membership figures high. As the example of one Gau shows, a membership level of $6.9 \%$ in 1935 could rise to one of $24.7 \%$ by 1942 . This shows that it was possible in one area at least for the NSV to move from a position of undoubted failure to one of reasonable success, even though it had taken the best part of eight years to achieve. ${ }^{l}$

The funds of the NSV have remained, to a very large degree, a mystery, given that no detailed figures have yet been discovered. But it seems that the NSV did not provide any details for publication as the WHW did, so that it is impossible to judge what the income from membership dues was. Given that these ranged from 50 Pfennigs and upwards in certain cases, the numbers of NSV members cannot be used to give an accurate account of income which came from this source. ${ }^{2}$ However, the annual subsidies to the NSV from the Gemeinden in 1936 are included within the files of the DGT, so for that year at least, it is possible to know how much the organisation received from

1. Ibid.

2. The only balance sheet found so far is the one for the month of January 1936 in the Gau Sachsen, (331294) NS37ii/1062. 
some of the major cities and the smaller communities at that time. ${ }^{l}$ During 1936, the DGT made an attempt to examine the levels of the subsidies which were being paid out by them to the NSV. This examination may have been inspired by worries over the rising levels of the NSV subsidies, so that every city and community was required to report to the DGT in Berlin on this matter. ${ }^{2}$ In the financial year of 1936, the NSV received as a subsidy from 77 selected Gemeinde (which possessed populations of over 50,000 inhabitants), the total sum of RM 3,973,856. The sum received from some of the larger cities for the same year was RM 2,836,669.3 However, given that a few of the smaller towns may have been included in the former figure, it has been decided to present these figures separately to avoid the danger of including the same sums twice over. In a comparison with the income from WHW collections for the same year, 1936, which amounted to RM $358,136,000$, it is clear that the NSV subsidies were not large, but given that they were spread throughout the country and made a valuable contribution to local NSV work in many areas, they were regarded as a most important source of income. 4 An examination of the sums outlined in the financial reports from the 77 selected Gemeinden shows how the sums were distributed according to specific NSV measures, so that these reports show, at the same time, how the activities of the NSV were operating throughout the country within the major centres of population during

1. BA, R36/964, 'Rundfrage/Beihilfen an die NSV/1936.'

2. Ibid.

3. Ibid., 'Rundfrage an die Gemeinden mit mehr als 50,000 Einw.'

4. BA, R36/962, Hilgenfeldt to Dr. Lippert, letter of 7 th December 1936. 
1936. ${ }^{1}$ The sums were divided up as follows under the following categories:

Subsidies to the NSV from 77 Selected Gemeinden according to specific measures of the NSV in 1936.

\begin{tabular}{|c|c|}
\hline & RM \\
\hline General Welfare & 335,480 \\
\hline Kindergartens, day centres & 254,861 \\
\hline Youth Care Preventive measure only & 119,297 \\
\hline Youth Care Recreational measures only & 51,900 \\
\hline Welfare/rent subsidies to individuals & 194,803 \\
\hline Holidays for children & 493,644 \\
\hline Health and ante-natal care & 163,072 \\
\hline Reduced cost school meals & 352,585 \\
\hline 'Mother and Child' & 162,634 \\
\hline \multirow[t]{2}{*}{ Other measures } & 833,831 \\
\hline & $2,962,107$ \\
\hline \multirow[t]{2}{*}{ Plus special measures } & $1,011,739$ \\
\hline & $3,973,856$ \\
\hline
\end{tabular}

The sum which the city of Berlin paid out for the NSV subsidy for 1936, was RM $349,380 .^{3}$ This particular figure was the second largest one paid out to an individual private agency for welfare, for Caritas and the Innere Mission who also received state funds, were allowed less than that with Caritas receiving a subsidy of RM 45,050 and the Innere Mission RM 204,800. But it was the Hitler Youth which was paid the largest subsidy in Berlin, and it was awarded the sum of

1. $B A, R 36 / 964$, 'Aufwendungen für Vereine,' 1936.

2. Ibid.

3. BA, R36/964, 'Rundfrage/Beihilfen an die NSV/1936'. 
RM 385,570 in 1936. The sums which the private agencies for welfare, including the NSV, in Berlin received from the public purse were as follows:

Private agencies including the HJ. Subsidies in Berlin 1936

General Welfare
Child Care
Youth Welfare
Youth care/recreat-
ional Measures of
the HJ

General Welfare

$76,740 \mathrm{RM}$

$571,820 \mathrm{RM}$

$9,800 \mathrm{RM}$

$385,570 \mathrm{RM}$
NSV/Subsidies

in Berlin 1936

$\begin{array}{lr} & 246,680 \mathrm{RM} \\ & 54,700 \mathrm{RM} \\ & 8,000 \mathrm{RM} \\ & \\ \begin{array}{l}\text { Recreational } \\ \text { Measures } \\ \text { of the NSV }\end{array} & 40,000 \mathrm{RM} \\ & \\ & 349,380\end{array}$

$1,043,930$

(1)

The amounts received by the NSV from some of the larger cities and towns is also shown as follows:

$\begin{array}{lrlr}\text { Tilsit } & 500 & \text { Furth } & 20,500 \\ \text { Plauen } & 600 & \text { Osnabruck } & 25,500 \\ \text { Zwickau } & 1,500 & \text { Heidelberg } & 24,500 \\ \text { Wiesbaden } & 3,250 & \text { Hannover } & 32,000 \\ \text { München/Gladbach } & 3,500 & \text { Kassel } & 33,000 \\ \text { Bamberg } & 4,600 & \text { Oldenburg } & 33,900 \\ \text { Halle } & 5,000 & \text { Mainz } & 41,760 \\ \text { Freiburg } & 5,072 & \text { Karlsruhe } & 48,170 \\ \text { Ludwigshafen } & 5,740 & \text { Kuln } & 69,300 \\ \text { Frankfurt/Oder } & 7,160 & \text { Rostock } & 69,500 \\ \text { Lubbeck } & 7,700 & \text { Nürnberg } & 100,000 \\ \text { Liegnitz } & 8,023 & \text { Stuttgart } & 105,400 \\ \text { Erfurt } & 9,000 & \text { Essen } & 148,300 \\ \text { Würzburg } & 10,000 & \text { Wuppertal } & 152,696 \\ \text { Darmstadt } & 10,200 & \text { Leipzig } & 162,310 \\ \text { Aachen } & 12,000 & \text { Duisburg } & 201,920 \\ \text { Bottrop } & 12,500 & \text { Düsseldorf } & 210,500 \\ \text { Jena } & 13,000 & \text { Dortmund } & 218,700 \\ \text { Regensburg } & 13,600 & \text { Hamburg } & 263,300 \\ \text { Saarbrücken } & 13,840 & \text { München } & 267,700 \\ \text { Koblenz } & 14,581 & \text { Berlin } & 319,680 * \\ \text { Bielefeld } & 14,750 & & \\ \text { Kaiserslautern } & 14,730 & & 2,836,669 \\ \text { Flensburg } & 15,300 & \text { Total } & \\ \text { Breslau } & 16,500 & & \\ \text { Augsburg } & 16,786 & \text { *Berlin figure shows } & \text { the } \\ \text { Frankfurt/AM } & 17,000 & \text { projected reduction of } & \\ \text { Dresden } & 17,681 & 29,700 & \\ & & & \\ & & & \\ & & & \end{array}$

1. BA, R36/964, 'Aufwendungen fur Vereine', 1936.

2. BA, R36/964, 'Rundfrage/Beihilfen an die NSV/1936.' 
It must be pointed out that the source of this information given above is a hand-written outline which may not show the final figure in every single case; however, given that the city of Berlin provided a final printed reckoning which is the same as the hand-written figure, less a projected reduction, these figures must be assumed to be entirely accurate in most cases.

The level of the NSV subsidies, at least in the city of Berlin, had risen sharply between 1933 and 1936. From RM 15,000 marks in 1933, the subsidy had gone up to RM296,000 and RM 350,000 in 1935 and 1936. ${ }^{1}$ An attempt to reduce this subsidy in 1936 , by RM 29,700 , was unsuccessful and led only to a series of heated exchanges between the state officials and the NSV. Spiewock, the head of the Berlin Landes-Wohlfahrts-und Jugendamt, had become anxious over the increasing level of the subsidy and was agreeable to its being reduced for that year. However, the imposition of a proposed cut in the subsidy seems also to have cost Spiewock his position as Gauamtsleiter of the NSV in Berlin, a job which he had held since $1934 .{ }^{2}$ It certainly seems as through Hilgenfeldt viewed this measure as a spiteful move on the part of the Berlin state welfare office and he may have been determined to get rid of an official who could be seen to be putting the affairs of the state welfare office before those of the NSV. Attempts to explain the reduction in the subsidy as an attempt to reduce costs generally, seem not to have cut any ice at NSV headquarters, and Spiewock's post was taken over by another

1. BA, R36/962 Spiewock to Stadtpräsident, letter of 20th January 1937.

2. Ibid, Hilgenfeldt to Dr. Lippe्र́t, 7th December 1936. 'Given that the NSV must be supported through the Decrees of lst July and 7 th December 1935, I cannot understand why the subsidy is to be restricted'. Questions about Spiewock's dismissal were put to Hilgenfeldt; Dr. Lippert to Hilgenfeldt, 4th February 1937. 
official who was not holding both a state and a Party position at that time. Spiewock's name was not included in the $1936 / 37$ lists of NSV Gauamtsleiter. ${ }^{1}$ Spiewock's close involvement in NSV activity in Berlin seems not to have prevented him from becoming more and more anxious during 1936 over the possibility that the state agency would become, perhaps sooner rather than later, a mere funding body for the NSV. This idea, he and many other state officials were agreed, was an entirely unwelcome one, and they viewed such a development with real abhorrence. ${ }^{2}$ Attempts on the part of the leadership to solve these problems, certainly before the war, could be described as desultory, with Ministerial Decrees putting the responsibility upon the NSV and the DGT themselves for the discovery of a solution. The Ministerial Decree of the 22nd September 1938, only reiterated that which the state and the NSV officials already knew, namely that the NSV was intended to provide supplementary measures only, though this particular decree explains that these Party measures were intended to be 'comprehensive in their scope', for the aid and the welfare of the German people. ${ }^{3}$ At best, the wording of the decree can be described as ambiguous and unhelpful, although it could also be seen as an invitation to the two parties to fight the problem out between them, as best they could, and to leave the leadership out of the issue as far as possible.

Within the measures of the NSV, it was only the WHW which

1. BA, NSD 30/29, Allgemeine Arbeitsanweisung(1).

2. BA, R36/1002, DGT to Fiehler, 'Ubertragung der offentlichen FUrsorge auf die NSV', 9th March 1939; Ibid., it is tempting to conclude that Spiewock was hoping to keep a close watch on NSV policy which his position as Gauamtsleiter of the NSV afforded him, for he seems to have been strongly opposed to NSV developments in Berlin at this time.

3. BA, R36/962, 'Erlass' of 12th October 1938. 
escaped entirely from the problems of Party and state. The WHW was economically self-sufficient, and could function without reference to the state officials, and whilst some rooms and halls were made available for WHW activities, no subsidies which would be earmarked for WHW work were paid out by the state. Most importantly, however, no comparable welfare measure was undertaken by the state welfare offices, which only assisted the WHW when they became involved with winter welfare work. The WHW therefore remained in a neutral position in relation to the existing state provisions. ${ }^{1}$

The problem of having allowed an organisation for Party welfare to develop on the scale of the NSV, but without reducing the scope of existing state provisions, meant that two potentially rival welfare agencies were unrealistically expected to function effectively, but without interference, in each respective area. This would of course prove to be impossible. Increasingly, ill-thought out welfare policies, which were supported by the ad hoc decrees and resolutions of the leadership, only served to create a situation which neither the state, nor the NSV officials, could solve. ${ }^{2}$

1. See Chapter Three.

2. BA, R36/962, 'Erlass' of 12th October 1938; NS 25/1233, Reichsminister des Innern, 'Entwurf', January 1941. 


\section{CHAPTER 3}

THE WINTERHILFSWERK OF THE NSV.

IDEOLOGY AND WEL TANSCHAUUNG

It is essential in any examination of the Winterhilfswerk to set the goals of the Nazi leadership clearly within the context of the measures and plans of this particular welfare aid scheme. For poorer citzens and low paid workers in Germany the Winter Aid Scheme acted as an emergency welfare facility which operated during the winter months. It was possible to obtain donations from the Winterhilfswerk of food, clothing and winter fuel where a low level of income made the purchase of such essentials difficult, or even impossible. ${ }^{l}$ The Winter Aid Scheme had several functions, not all of which may be readily attributable to the desire to give material help to the poorer members of the population. Indeed in no other section of the NSV's welfare arrangements was the combination of welfare and propaganda so potent and potentially successful. ${ }^{2}$ In no other welfare measure was it so obvious that the function of welfare was predominantly designed to foster attitudes of loyalty and service for the nation which the Nazi government hoped would be enshrined within the hearts and minds of Germans. From the start, the new leadership sought to evolve a new social order by creating the 'Volksgemeinschaft' or People's Community which would exist as a harmoniِ nats national community freed from class conflict, and also

1. This was true for many, both before and during 1933. See Mason, Sozialpolitik, pp.88-98; BA, NSD 30/34, Allgemeine Arbeitsanweisung (2) for a detailed outline of the Winterhilfswerk (WHW).

2. See British newspaper reports on the WHW, 1933-1938, Clippings Collection, Wiener Library, section P.c.5(119). HA, 14/262, 'Eryffnung des WHW durch den FUhrer', pp. 306-314. 
dedicated to supporting the Nazi government. ${ }^{1}$ However, the individual citizens or Volksgenossen needed to be informed, educated and indoctrinated with regard to the standards of behaviour and types of loyalty which would be appropriate within the newly ordered Nazi Reich. ${ }^{2}$ A new type of citizen was envisaged by the Nazis, but he had yet to be created so that the 'ideal citizen' of the New Germany existed only as a theoretical construct. It was towards the creation of this new type of social entity that the measures and plans of the Winterhilfswerk, including the NSV and the other Nazi organisations, were directed. ${ }^{3}$

of the many problems which faced the new government in January 1933, perhaps the most pressing was, as its leaders knew only too well, that the confidence and support of a large section of the German Nation had still to be won over. Many still had to be persuaded of the value and significance of the Nazi movement, indeed to attain an understanding of what National Socialism demanded from

1. See Althaus, NS-Volkswohlfahrt; Hilgenfeldt, Idee.

2. Johannes Ehrhardt, 'Erziehungsdenken und Erziehungspraxis des Nationalsozialismus', Ph D thesis, Freien Universitat Berlin 1968, see 'Die Weltanschauung', pp.32-47; 'Die Propaganda', pp.52-56; Ralf Dahrendorf, Society and Democracy in Germany, London 1965, pp.402-418.

3. Erich Hilgenfeldt, Aufgaben der Nationalsozialistische Wohlfahrtspflege. Speech given to the Reichsparteitag der Arbeit, 1937, MUnchen-Berlin 1937; BA, NSD 30/34, instructions for Gau organisers of the WHW with short excerpts of speech given by Hitler on 6th October 1936, 'Es ist ein neuer Mensch geschaffen worden, und dieser Mensch hat unerhbrte Opfer auf sich genommen'. See Allgemeine Arbeitsanweisung (2); Stephenson, The Nazi Organisation of Women, pp.130-172; Wieland Elfferding, 'Opferritual und Volksgemeinschaftsdiskurs am Beispiel des Winterhilfswerks (WHW), in Faschismus und Ideologie 2, (Hrsq.), Manfred Behrens, Berlin 1980, p.204. 
the so called 'valuable' or 'Aryan' majority.' Even though electoral successes had shown that a degree of support was forthcoming after 1929 from the ranks of wage earners who, in the main, were neither organised in trades unions nor had regularly voted for the SPD or KPD in the past, the leadership knew that a considerable effort still lay ahead. ${ }^{2}$ Even though the political parties and the trades unions had been swiftly abolished, and opponents and critics effectively silenced, coercive measures were not regarded as being sufficient in themselves to secure the willing, and most importantly, the active support of every section of German society. ${ }^{3}$ The election of 5 th March 1933 had shown that an absolute majority for the Hitler government had only narrowly been reached when the NSDAP itself had received $43.9 \%$ of the votes cast. While it is true that the NSDAP had thereafter achieved party political monopoly in July 1933, making it impossible for other political forces to participate actively within the political life of the nation, there existed, and would continue to exist, a 'conflict-ridden' balance between Party and state. ${ }^{4}$ These political developments would affect the working and the activities of the NSV, but not, to any serious extent, those of the WHW, which operated in a fairly independent manner, rising above the conflicting interests between Party and state in its operations,

1. HA, 14/262, NSV History 'Der Dreimonatsplan fur Bevblkerungspolitische Aufklärung', p.290.

2. Ehrhardt, 'Erziehungsdenken', pp.69-113; Mason, Sozialpolitik, Chapter Two; David Schoenbaum, Hitler's Social Revolution, London 1967, p.71.

3. BA, NSD $30 / 2$ 'Davon sprich zur Volksgemeinschaft', in NS-Volksdienst, November 1938; HA, 14/24/261, pp.306-314; BA NSD/30/1(5) Hans Bernsee, 'Zwei Jahre NSV', in NS-Volksdienst, May 1935.

4. Broszat, The Hitler State, see foreword to English edition, p.X. 
and managing to steer clear of the problems which other NSV sections found difficult or impossible to avoid. ${ }^{l}$ Insofar as clashes between State arrangements for welfare and the WHW could be avoided, leaving the WHW to operate as, perhaps, the 'purest' form of Nazi welfare, an examination of the WHW and its intentions reveals a clear picture of the aims of the leadership with regard to a future social structure dedicated to upholding Nazi 'ideals'. 2

It was active support which the new government longed to have from the population, though in many instances a lesser level of engagement would be all that they could realistically expect, with passive acquiescence a substitute for real support. ${ }^{3}$ But the means whereby such support might be achieved still had to be found. No-one understood this problem better than the Propaganda Minister, Dr. Goebbels, who warned his staff that it was one thing to break down the outer resistance of the mass of the German people, but quite another to overcome their inner resistance. This required a fundamental change in the point of view of the individual, in his attitudes and his prejudices. It was this fundamental change of attitude and perspective which the NSV's Winter Aid Scheme was

1. See particularly the Jugendhilfe section of the NSV. The clash between the NSV, Deutscher Gemeindetag and leading state officials, led to a series of bitter arguments about the Party's arrangements for youth welfare, as organised by the NSV and those of the state Jugendumter. See also Chapter Five and Introduction.

2. The Winterhilfswerk, which was run by the Propaganda Ministry and, of course, Goebbels, could operate relatively freely without interference from state officials; Prof. Dr. Bruno Rauecker, Social Policy in the New Germany, Frankfurt 1936, p.37.

3. BA, NS $3 i i / 1062$, confidential reports of 1935 from NSV Sachsen; Kershaw, 'How Effective was Nazi Propaganda?', pp.187-190; Stephenson, The Nazi Organisation of Women, pp.214-219. 
designed to procure. References to the emergence of the ideal citizen, the 'Aryan' Volksgenosse were tirelessly repeated in speeches and writings on the Winter Aid Scheme. The creation of this new social entity (whose English translation 'folk' can only insufficiently describe the true meaning), had a precise political function. References to the Volksgenosse or member of the People's Community in speeches and writings after 1933 were a propagandistic device specifically intended to bring about the development of a Nazified society. The endless repetition of 'Volk' and 'Volksgemeinschaft' was primarily aimed at the population as a whole, and was designed to persuade them that the nation would be, under Nazism, united into one harmonious whole. ${ }^{l}$ Propaganda statements which referred to the 'People's Community' were, in effect, the means by which the leadership might hope to win the support of the population, and most particularly of the industrial working class whose existence with reference to the political movements representing it, had been massively repressed in the spring of 1933.2 The use of the term Volk was both intentional and in many instances entirely cynical. But the untranslatable term 'Volk' was carefully chosen, for it was suffused with meaning for the German speaker at that time, redolent as it was of romantic longings for the past, and inspired by an altogether mythical significance which is entirely lost on the English reader. However, the use of the term Volk was in truth primarily a device which, it was hoped, would flood with meaning the utterances of the WHW, thereby allowing the desire,

1. Reher, Social Welfare, pp.1-12. BA, NSD 30/1-4(a), NS-Volksdienst 1933-1942. See especially 'Soziale Arbeit ist Aufgabe der Volksgemeinschaft', February 1933, p.129.

2. Mason, Sozialpolitik, pp.42-123. 
previously dormant in the hearts of the people, to awaken and inspire the nation to unite in such a way as to render class, and party loyalties meaningless. ' The Party, through the WHW, was continually able to call upon the idea of the nation which was mystically united by the ties of blood; it could therefore in effect ignore the troublesome rhetoric of class ideology. The writings and the measures of the WHW drew upon what the German writer Thomas Mann has described as that volkisch layer which exists, if it exists anywhere, within the subconscious, or, at any rate, out of the reach of rational action. Every appeal to Das Volk, a term which, moreover, combines three distinct ideas, namely, nationalism, race and anti-semitism, was an appeal to a particular aspect of superstitious behaviour in the individual which tends to encourage a suspicious dislike of others who are, by whatever means, labelled dangerous or merely different. ${ }^{2}$ It is not difficult to see that the ideal of racial purity and the existence of the elite German nation formed the fundamental basis of the Volksgemeinschaft. The nation as a whole was the more likely to close ranks behind the NSDAP if it could be persuaded that the ties of blood superseded any class affiliations. $^{3}$ The real significance of the Nazi interpretation of the volkisch myth was that by its constant re-iteration, disparate groups would be informed by the Party and the

1. BA, NS37ii/1058, Propaganda Instructions, 'Winterfeldzug 1936/37', 'Wir bauen der Fundament des Ewiges Deutschland'; Hilgenfeldt, Idee, p.8.

2. Thomas Mann, Dr. Faustus, London 1983,p.40

3. $B A, N S D / 30 / 5$, Sondernummer NS-Volksdienst, Autumn 1935; BA, NS 37ii/1058, 'Winterfeldzug', P.2; VB, 'Dr. Goebbels dankt den Sammlern und Helfern des WHW', 5 th December 1938, see Clippings Collection Wiener Library. 
WHW, being thereafter continually reminded, that they belonged to a unified (and purified, through the exclusion of certain groups), elite racial community within which class conflict had been abolished. ${ }^{l}$ A mixture of cynical detachment and romantic idealism and, not infrequently, a measure of sheer opportunism, characterised every statement which issued forth from the WHW offices in Berlin concerning the new elite nation, whose very existence was entirely problematic. There is good reason to believe, however, that all references to the Volk contained both a plea and a huge gamble, which functioned as a major element in numerous attempts to gain support on behalf of the leadership. This added perhaps, some political weight to the more lunatic utterances which involved the theoretical existence of a 'superior', 'Aryan' race. Perhaps there was little choice for the Nazi leadership but to attempt to create a new type of society, indeed a new social order. When they abolished the political parties and destroyed the trades unions the leadership created, not unintentionally, a massive gap within the very fabric of German social life by ripping away, as it were, the social anchorage of previously existing class and party loyalties. The role of the new citizen, the Volksgenosse, would be able to grow and develop insofar as the opportunity for privately organised activities, either of a social or apolitical nature were restricted, and ultimately reduced, in scope. ${ }^{2}$ The firm belief that the 'gap' which had been created through a restriction of opportunities for certain types of social interaction within German society could eventually be filled by the debased idealism of the Nazi Weltanschauung is central to an

1. Die NS-Volkswohlfahrt als Kulturträgerin, Munich 1938;

H. Stbrmer, Die NS-Volkswohlfahrtspflege, Berlin 1940.

2. Dahrendorf, Society and Democracy in Germany, pp.408-413. 
examination of the Nazi organisations in general, and the WHW in particular. The existence of the new citizen, the Volksgenosse as an organic member of the new social order, was tied to the conviction, albeit a mistaken one as events were to show, that an inherent national unity would develop and sweep aside all social and ideological barriers. A nation would emerge which would be responsive only to the virtues of duty and self-sacrifice, courage and comradeship. According to Timothy Mason, this was the essential gamble of National Socialism. ${ }^{1}$ It is within this particular context that the redefinition of the role of citizen in the Third Reich must be placed, for though Reich citizenship was given a legal framework in 1935, one which allowed all Jews by virtue of their 'non-German' blood to be stripped of their rights as citizens, the legitimate existence of the true member of the People's Community related not so much to a legal category, as to a particular frame of mind. ${ }^{2}$ of the many lessons to be learned, which were constantly, and almost without variation repeated in the journals and periodicals of the NSV, the most important was that a sense of duty responsive to the needs of the community should emerge. It would replace the essentially disruptive idea of the free, privately motivated individual acting as a responsible agent, being legitimately concerned with his own political rights. The endless repetition of 'Gemeinnutz geht vor Eigennutz' (the community before the individual), expressed the total rejection of liberal ideas. For example, in the words of one of the

1. Timothy W. Mason, 'National Socialist Policies towards the German Working Classes 1925-1939', D.Phil thesis, Oxford 1971 , p.19.

2. BA, NS37ii/1058, 'Winterfeldzug', see 'Die ideale Erziehung der Volksgemeinschaft durch das Winterhilfswerk'. 
leading officials of the NSV, Werner Reher, it was to be perceived that,

'the truth that not one of us is self-sufficient but that we are all dependent on one another has come to be recognised in its practical implications by all who desire to see social justice promoted and established. Thus it may be said that the nation has become as one great family whose maintenance can be assured only insofar as the single members of that family are physically sound, morally steadfast and willing to sacrifice individual interests to whatever extent that may be necessary'.

The extent to which individuals, after 1933, actively pursued a conscious denial of personal interests, having been persuaded by propaganda such as this vague, indeed vacuous, statement, which was typical of many produced by the WHW, seems according to most historians to have been at best, only minimal. ${ }^{2}$

Perhaps more successful was the emergence of a very real assault on the private existence of countless individuals on the part of the Nazi organisations, and the WHW in particular. ${ }^{3}$ The development within the hearts and minds of German citizens of a sense of Opferbereitschaft (readiness to serve) may be more correctly described as a resigned acceptance of the necessity to turn out and perform the different kinds of voluntary, unpaid work which was the main, indeed the only, reward apart from certificates of honour and, only infrequently, 'Honour Badges', for one's membership of a Nazi Organisation. Nevertheless, the WHW was able to call upon as many as

1. Reher, Social Welfare, pp.9-10.

2. I am grateful to $\mathrm{Dr}$. Jill Stephenson for giving me information about the shortages of NSV welfare aides through unwillingness to participate in social welfare measures in werttemberg in 1941; Kershaw, 'How Effective was Nazi Propaganda?' pp.187-201.

3. Mennecke, Ein westdeutscher NSV-Kreis, p.l. 
1.5 million volunteer helpers during its first year which does suggest that the WHW charity drive caught the imagination of citizens who had perhaps up to then, been indifferent to the idea of giving of their free time for a public cause. ${ }^{1}$ National Socialism was not so much set against individual effort per se, as against efforts by individuals whose goals were essentially private. The Volksgenosse was, as a citizen of the Reich, a social type whose private existence had ceased to occupy a central position within the constellation of social activities and interests which made up the life of the individual. This 'type' was, of course, only a theoretical construct to which, in order to hasten its development much of the WHW propaganda made pointed reference. However in the written material the existence of such Volksgenossen was referred to in such a way as to give the impression that such 'ideal' citizens already existed and that, in many ways, they had always existed, and were only waiting for the Nazi Weltanschauung to revivify them. In most of the written material there exists a confusion about the 'creation', on the one hand, of such a citizen type, and, on the other, of the 'reawakening' of a slumbering sense of 'Opferbereitschaft'; this was not to be mistaken for 'weak' liberal-minded charity orientated activity of the kind which had undermined the nation in the past. ${ }^{2}$ The WHW at all times, and in every possible example, emphasised the need to 'strengthen' those who would receive WHW welfare, above all by not allowing them to become 'dependent'

1. Reher, Social Welfare, p.12; Erich Hilgenfeldt, 'NSV und Winterhilfswerk', FZ 14th September 1935, Clippings Collection, Wiener Library.

2. Ingeborg Altgelt, Wegweiser, see Section $\underline{A}$, 'Wohlfahrtspflege einst und jetzt', pp.9-13. 
upon such welfare aid as was forthcoming. Indeed all NSV welfare carried this particular emphasis. ${ }^{l}$

It seems possible to agree with Dahrendorf that the role of the Volksgenosse could, and in many cases did, 'swallow up' other memberships and loyalties. ${ }^{2}$ Even if as he points out, it was only by preventing the chances for participation in a social existence which was not subject to Nazi pressure. Nevertheless at all times, when the individual Volksgenosse participated in public affairs by virtue of his or her membership of an organisation (such as the WHW), that participation existed merely as a 'demonstration of someone else's power'. 3 From this point of view participation in the welfare work of the WHW was intended, albeit on a trivial level, to legitimise the 'powerless' aspect of all active individual effort by citizens within the Third Reich. ${ }^{4}$

The WHW actively fostered an alteration in the perceptions of one's loyalties and duties as a citizen so that the leadership could gain firm support not only for the government, but for the Party's organisations, including the WHW, which should become 'positive reference' groups. ${ }^{5}$ It would eventually become both acceptable, and 'desirable' to put the claims of individual interests second to the

1. HA, Reel 13/259, 'NSV-Jugendhilfe'.

2. Dahrendorf, Society and Democracy, pp.408-411.

3. Ibid., p.411.

4. BA, R36/1008, instructions from DGT on the collections for WHW during 1937/38, 18th November 1937. Working for the WHW might have had the function of distracting attention from the more unpleasant features of life in the Third Reich, this was reported to me in conversation.

5. This argument follows a social/psychological analysis of the formation of social attitudes. See T.M. Newcomb, 'Attitude Development as a function of Reference Groups: The Bennington Study', in Understanding Society, London 1970, pp.494-585. 
duties and responsibilities of one's citizen role; but this difficult transition would be made easier, and perhaps less intellectually and emotionally suspect, through active involvement in a welfare scheme which was designed to aid the less fortunate. Active support for the Nazi leadership was more likely to be given if Nazi organisations such as the NSV, and the WHW, could be perceived positively and as a desired group to which many would wish to belong. But it is true to say that in some cases, though not all, membership of a Nazi organisation signalled little more than the hope that by paying lip-service to Nazi ideals one would be left in peace. Nevertheless, the WHW leadership intended that participation in its measures and numerous activities would arouse a more positive orientation in the minds of citizens. ${ }^{l}$ It was for this reason that,

1. $B A, R 36 / 1009$, letter from Hilgenfeldt with regard to recognition of three months uninterrupted work for the WHW, 'Rundschreiben Nr. 98', 29th January 1935; NSD/30/45, copy of certificate, 'Ehrenkunde dem Ehrenamtlichen Helfer im Winterhilfswerk des Deutschen Volkes 1937/38'; St.J., 1938, pp.596-597. Monthly average figures of voluntary helpers for the WHW are given as follows:

\section{Numbers of helpers monthly during the winter}

\begin{tabular}{|c|c|c|c|c|}
\hline \multicolumn{4}{|c|}{ Ehrentamlich Helfer } & Helfer mit \\
\hline \multicolumn{2}{|c|}{ Standige } & $:$ & WHW Helfer & Gehalt oder \\
\hline NSV/-Wal & ter & $:$ & & Entschaddigung \\
\hline $1933 / 34$ & & 195 & 000 & 4,116 \\
\hline $1934 / 35$ & 308,262 & : & $1,024,875$ & 5,198 \\
\hline $1935 / 36$ & 580,958 & : & 646,140 & 7,820 \\
\hline $1936 / 37$ & 706,598 & : & 633,758 & 8,652 \\
\hline $1937 / 38$ & 588,897 & : & 431,355 & 10,036 \\
\hline
\end{tabular}

From the figures given above it seems to have been necessary to pay more WHW workers as the numbers of voluntary helpers were falling from 1934. But these figures also show that the numbers of NSV Walter were rising, apart from 1937/38. 
notwithstanding passive membership by many in Nazi organisations, all citizens (though not Jews) in Germany were addressed, by the leaders of the WHW, as by those of other organisations, as Volksgenossen at all times, whether they themselves had accepted the idea or not; indeed it was utterly impossible to escape the designation. While it is certainly true that a seemingly endless stream of inflated rhetoric flowed from the offices of the WHW, to function in the service of promoting these ideas, it must be remembered that the leadership was deadly serious when it called for allegiance from citizens. Those who openly showed themselves to be unwilling to meet the claims of the leadership were treated very harshly indeed. A public show of frank opposition to the Nazi Volksgemeinschaft could result in the loss of the right to rear one's children, or in the case of a relatively minor offence, a stay in prison for a short period. This latter fate also befell those who ignored the rules which surrounded the use of WHW welfare, which was intended for consumption by families, not to be sold for profit, or to finance a drinking habit. ${ }^{1}$

The citizen after 1933 had duties to perform which, in theory at least, mirrored the responsibilities of the Volksgemeinschaft to provide welfare aid for the less fortunate. This symbolic partnership which both citizens and community were meant to enter into existed only in theory, but it was one which, itwas intended, neither the citizen nor the Volksgemeinschaft would shirk. ${ }^{2}$ The WHW

1. The Manchester Guardian, 23rd March and 29th May 1934;

Elfferding, 'Opferritual', p.219.

2. BA, NS/37ii/1001, Folder 2, short article, 'Das Wesen Nationalsozialistiche Volkswohlfahrt', 1936. I am grateful to Herr Joachim Weiss of the University of Guttingen for pointing out this, and other files, in the Bundesarchiv, Koblenz; Elfferding, 'Opferritual', pp.220-226; Hilgenfeldt, Idee, pp.17-18. 
was the visible expression of such a partnership between citizen and national community which was annually, demonstrated throughout the whole of the Reich. ${ }^{l}$ Again and again social welfare as distributed by the NSV and the WHW was defined in terms of a double-sided duty of community and citizen. ${ }^{2}$ Both the partners would undertake to participate in a mutually supportive scheme from which all references to alms or charity had been excluded. As Reher put it,

'Whatever help is given to the individual must not be given as an alms. It is the duty of the community to render assistance in cases of need, not a work of supererogation but as a work that is necessary to maintain the existence of the community itself. In the Marxist and liberalistic systems the individual and his needs form the point of central interest, but that is not so with the National Socialist welfare system; here the community of the people is the primary and essential object of care'.

The WHW was charged with helping to inform the population that the individualistic aims of earlier times were no longer acceptable. Apart from providing material aid for the less-well off, the WHW provided a whole range of measures which outlined the new roles of citizen and community in Nazi Germany. These were intended to be designed with the most effective use of propaganda available at the

1. BA, R36/1009, Instructions to all Gauleiter der NSDAP, Gaubeauftragte WHW on WHW, 1934/35, from Reichsbeauftragter, 'Rundschreiben Nr. 109', 10th May 1935; Ibid., VB, 'GrosskUche fUr das Berliner WHW', 17th September 1939. K. Herbst, Die NSV dient der Volksgemeinschaft, Breslau, 1939; pp.2-15.

2. Hilgenfeldt, Idee, pp.11-12.

3. Reher, Social Welfare, pp.6-8. These arguments follow Hilgenfeldt's exactly. 
time. $^{l}$ Some of these measures were purposely created with an ideological and emotional maleability which was unique among NSV measures. For example, the collections of money and goods from the community could be publicly depicted as a 'sign' of willingness to sacrifice (for other, less fortunate persons), or as 'proof' of support for the Nazi government, in the press and on radio. ${ }^{2}$ The huge sums collected were reported to be an outward display of an 'inner acceptance' of Nazi rule. The act of donating to the WHW, even a few Pfenni z̧s in many cases, was imbued with an emotional intensity which was manufactured by the Propaganda Ministry into heady stuff. The 'hot air' aspect of the WHW was easily picked up by foreign journalists at the time who, almost to a man, saw through the propagandistic aspect of WHW and accurately reported the 'real', that is the manipulative, function of welfare campaigns run by the WHW. ${ }^{3}$

E.K. Bramsted has suggested that all special appeals and campaigns undertaken by the Propaganda Ministry, which included also the NSV's Winterhilfswerk, masterminded solely as it was by the Propaganda Ministry, were intended on the whole to enliven the daily dose of propaganda which was to become such a familiar feature of

1. Ibid., P.8; BA, R36/1008, 'Jeder hat die Pflicht zu helfen', in Berliner Tageblatt (October) 1936; Ibid., instructions from DGT, 'Winterhilfswerk 1937/38', 12th October 1937; Ibid., 'Die Stadt Oberhausen brachte als Opfer fur die notleidenden Volksgenossen 517,900 Mk. auf', design for Plaque WHW 1934/35; R36/1009, letter from Hilgenfeldt reminding all concerned of guidelines for the acquisition of the monthly poster of the WHW, 'Rundschreiben $\mathrm{Nr}$. $99^{\prime}$, lst February 1935.

2. $B A, R 36 / 1009$, Letter from Hilgenfeldt on methods and arrangements for WHW 1934/35 'Rundschreiben $\mathrm{Nr}$. 109', 10th May 1935. VB, $11.10 .34 ; 7.10 .36$; 17.4.37; 5.12.38, Clippings Collection Wiener Library

3. Ibid., see British newspaper reports 1933-1938. 
German life. While one may agree to some extent with such a point of view, it must be argued that to describe the WHW in such a manner misses the real purpose of WHW campaigns entirely. The concept of National Solidarity and the existence of the Volksgemeinschaft, which was given prime importance in all WHW campaigns, and written material, were presented as stolidly and with as much tedious repetition there as anywhere else. ${ }^{l}$ It would also seem unlikely that the WHW's six-month long charity drive, from October to March, could sustain a lively impact, year in, year out. There seems no reason to doubt that the leadership viewed the WHW measures, and the street collections in particular, as a serious exercise in self-help which had an important educative function. Most importantly, the collections were regarded by Hitler as 'one of the most precise means by which the leadership could ascertain the real attitudes of the people for its measures and plans'. How wrong this would prove, would be shown during the war when Gauleiters were more concerned to compete with one another than follow WHW rules. Even during the war, when demands on scarce manpower suggested that WHW funds might be collected and distributed in some other way, the public collections by individuals continued as before, mainly because of,

'their extraordinary political significance, for the collection of money and articles indicates to every person the great tasks of the community in a propagandistically effective and thorough manner'.

1. E.K. Bramsted, Goebbels and National Socialist Propaganda 1925-45, Michigan 1965, p.102. BA NSD 30/5, 'Sondernummer', NS-Volksdienst, 1935; NSD 30/2, NS-Volksdienst, November 1938, 'Die Kraft der Gemeinschaft', p. 417; Hilgenfeldt, Aufgaben, p.3.

2. Aryeh L. Unger, The Totalitarian Party, London 1974, p.209. See also Chapter Seven.

3. Ibid., pp.208-9. 
The NSV's WHW campaigns and measures have also been described as an example of 'propaganda of the deed', for they provided an excellent springboard for the mobilisation of the masses, not only because of the gratitude which would be engendered by welfare, but because the mechanics of welfare administration projected Party influence into the home, and thereby provided an additional channel of Party control. ${ }^{l}$ This aspect of NSV activity certainly shows most clearly in its 'Mother and Child' section through the activities of the officials of the NSF's Reichsmutterdienst (Reich mothers' service) courses, which, as part of a course, sent the tutors on home visits to assess the domestic arrangements. ${ }^{2}$ Thus, welfare administration projected Party influence straight into the home. As Unger has pointed out, the insight into the intimate affairs of the individual and the family that was ordinarily denied the Party functionary was available to the social workers and voluntary aides of the NSV and the WHW.

By encouraging a measure which required the use of a personal act, namely a donation to the WHW, which was perceived as a sign and a confirmation of one's loyalty, the Nazi leadership regarded the WHW as a highly useful means by which various lessons could be put across to the public. The idea of the donation, as it was expressed by the WHW, was a symbol of a reciprocity of intention which was held by community and citizen alike. ${ }^{3}$ Not only that, but it was a truly

1. Ibid., p.204.

2. Scholtz-Klink, 'MUtterschulung', in A Contribution/III International Conference, pp.137-149.

3. Ibid., p.140.; Hilgenfeldt, 'Die Volksgemeinschaft als Ausgangspunkt und Ziel im heutigen Deutschland', pp.1-6. 
visible action which no-one could ignore, and which displayed the 'concern' of the Party for the mass of the people, who themselves turned out in their thousands armed with red collecting tins into which was placed the sign of acceptance, that is to say, one's donation. $^{1}$ It must be emphasised that donations to the WHW frequently were given without a sense of good will or any other positive attitude. However this fact does not detract from the manifest intention of the WHW which could, in some instances at least, elicit support in the form of a donation, freely given. The extremely personal and emotional impact engendered by this type of action and support was clearly shown by the donations which were sent directly to Hitler himself; these particular donations were carefully filed as being personal to the Fuhrer. ${ }^{2}$ One such donation from a woman during the war was accompanied by a poem written by herself: 'Sind wir nicht alle zum Opfer bereit und zu dem Tod?' ran the last line of one of the stanzas. ${ }^{3}$ The donations like other measures of WHW drives show how important the concept of reciprocity of mutually held responsibility was, within the ideological framework of all WHW activity. The desire to create a positive orientation was ever-present in WHW measures and plans right from the beginning. For example, $W$. Sheridan Allen says of

1. BA, R36/1010, letter from Hilgenfeldt to all Gauleiter/Gaubeauftraqte WHW, on slogan to be used on WHW posters 'Give your donation as a (willing) sacrifice not as an alms', 9th February 1935; Elfferding, 'Opferritual', p.204.

2. BA, R43ii/560, letter to Reichsfuhrung/WHW, from the Reich Chancellery, 8th October 1942.

3. Ibid., letter to WHW in Berlin from Reich Chancellery, with copy of letter and poem from Lieselotte Pryschel, including donation of RM 2.00, 8th February 1943. 
'Thalburg' in 1933 that most of the citizens there approved the idea of erecting a Christmas tree in the Market Square (paid for by WHW funds), 'so that everyone in Thalburg could enjoy one'.'

Though it was emphasised during the WHW drives that 'one must come to the aid of the poorest of the poor', as Goebbels (succinctly) put it, it is also true that the donation to the WHW was regarded as a 'sign' of a pro-Nazi, or potentially pro-Nazi, viewpoint. The clear knowledge that this was manifestly not the case in many ińtances did not deter the WHW, nor detract from the intention to use the donation to the WHW both as a barometer of opinion, and as a means in itself, not as an end. It was the reciprocal act of donating/receiving which was seen to be capable of creating the intention to support the leadership, not merely the receiving of welfare aid as such, however welcome that might be. ${ }^{2}$ The visible demonstration to oneself, and others, that the community must be supported, by an action of symbolic giving and receiving, took on as time passed an almost religious note in the WHW campaigns. ${ }^{3}$ It is this facet of WHW activity which makes an assessment of its 'success' or 'failure' such a difficult undertaking.

The donation to the WHW was something which could be counted by the leadership as a first step on the road to a 'positive' acceptance

1. William Sheridan Allen, The Nazi Seizure of Power: The Experience of a Single German Town 1930-35, New York 1973, p.269.

2. Elfferding in 'Opferritual' makes a similar point which differs significantly from de Witt's emphasis, see pp.204-205.

3. $B A, R 36 / 1008$, from DGT on instructions regarding WHW 1937/38, 12th October 1937; Ibid., 'Adolf Hitler Spende der Deutsche Wirtschaft', see Section 3, 'Tag der nationalen Solidaritat', and list of instructions on WHW 1937/38, 18th November 1937. 
of Nazi rule. This emphasis on promoting acceptance of Nazi aims through personal 'action', was present in Nazi welfare measures right from the start. ${ }^{l}$ The reciprocal nature of this particular device of the WHW was clearly shown on the 'Day of Solidarity', always a Sunday, when prominent Nazis were expected to proffer the ubiquitous collecting tin themselves. ${ }^{2}$ It must be suggested that one of the functions of the WHW was to act as a trigger for the adoption of new attitudes, such as the ones outlined above. The WHW made a significant addition within an atmosphere of a general proliferation of uniforms, insignia and other visual reminders of the Nazi State. The WHW was itself the most visible presentation of the NSV's social welfare schemes; probably no other scheme of the NSV so determinedly pushed itself into the consciousness of the people although other NSV schemes were meant to be usefully persuasive in pushing the Nazi message (most notably the NSV's 'Mother and Child' scheme). ${ }^{3}$ The stamp of Goebbels' Propaganda Ministry existed in every WHW measure for it was he, Goebbels, who was chosen to run the entire scheme until the end of the war, not Hilgenfeldt, the leader of the NSV. ${ }^{4}$

1. HA Reel 13, Folders 258/9/260, Reel 14, Folders 61/62.

2. BA, R43ii/564a, from Hauptstelle Aktive Propaganda' to Reichskanzlei, instructions for 'Day of National Solidarity', (3rd December 1938), 17th November 1938; Ibid., Gau Gross-Berlin, Gaupropaganda Amt, 'Tag der nationalen Solidaritut, Sonnabend, den 3.Dez. 1938', 28th November 1938; Ibid., 'SammelbüchsenListe', with Dr. Lammers' name and information on amount $(1,391.98 \mathrm{RM})$ which he collected on 3rd December 1938; the Evening Post 1934 reported that Goebbels made his collections with an SS man's hat to facilitate the collection of notes, see Clippings Collection Wiener Library.

3. BA, NS $22 / 750$, from Bormann, on instructions to keep the 23rd December free for WHW activities. 'Rundschreiben $\mathrm{Nr} .147 / 37^{\prime}$, 6th November 1937.

4. HA, 14/262, p. 306 . 
The first WHW drive which took place during the winter of $1933 / 34$ was pronounced a resounding success in the NSV's journal, NS-Volksdienst. The first campaign had shown that, 'after only half a year of Nazi leadership the people were ready to follow the Fuhrer's thoughts and measures'. Not only this, but the same article asserted firmly that:

'one realised with deep joy that the misguided doctrine of Marxism had never taken root in the heart of the German worker, only the dominating influence of Marxism over some numbers of years had caused a suspension of the critical faculties of the German worker'.

The work of the WHW, with its collections of money and distribution of goods in the form of food, clothing and fuel was, according to WHW propaganda, meant to show that a 'Spirit of Solidarity' was invested in Nazi measures to counteract poverty and need. ${ }^{2}$ The NSV's leaders were not slow to point out in articles, periodicals, and in the vblkischer Beobachter that all this effort showed just what 'real' socialism consisted of. ${ }^{3}$ However, one must treat with care all statements which dealt with pronouncements on 'socialism' in WHW, and NSV, propaganda. As Schoenbaum has pointed out, the word 'socialism' as used by Nazi leaders usually meant something which he describes quite accurately, as:

'a basic social egalitarianism with a streak of social welfare, and a considerable element of militancy'.

1. BA, NSD 30/1, NS-Volksdienst, October 1934, p.3; Ibid., p.5.

2. Sturmer, Das Rechtliche Verhaltnis, pp.29-69.

3. BA, NSD 30/1 NS-Volksdienst, October 1934, pp.1-16.

4. Schoenbaum, Hitler's Social Revolution, p.57. 
In 1933, Goebbels told an audience in Kunigsberg that 'our socialism is a socialism of heroes, of manliness'. ${ }^{l}$

Ley was also heard to declare that, 'our socialism has nothing to do with pity' a sentiment with which the leader of the NSV could easily have agreed. Ley also went on to say that:

'socialism is community, struggle and comradeship, loyalty and honour; socialism, my friend, is the blood and the race, the holy solemn belief in God'.

Schoenbaum correctly points out that the socialist label was often applied to activities that had hitherto been called 'sozial', such as social work. What seems to have been meant in NSV/WHW propaganda, when the word socialism was used, was essentially the idea as expressed by Hitler, that people had to be educated towards an acceptance of the need to 'help themselves', and also others who needed assistance and who formed that section of the nation who were 'worthy'. The 'Aryan' nation would be expected to accept, and subsequently to internalise, the values of National Socialism in general, and a sense of community responsibility, in particular. This was what socialism after 1933, as the term was used in Nazi writings and speeches, really meant. Hitler described the whole Winterhilfswerk as a means of educating the German people to socialism. ${ }^{3}$ But it is clear that he meant a type of socialism resembling the definition given above. The Nazi leadership expected that the act of participating in a practical exercise, designed to alleviate social distress and economic hardship, would itself function in a socially cohesive manner. Moreover, welfare activity

1. Ibid.

2. Ibid., pp.57-58.

3. Hitler, Zweites Buch, Stuttgart 1981, p.78. 
would promote, at the level of the community, through a myriad of personal social contacts, social change of a distinctive kind which, at all times, would function as a support for Nazi policy. In other words, people would come to forget, or better still, reject, the liberal values of earlier times which, as some have argued, had never taken root in Germany to any significant degree. ${ }^{l}$ Nevertheless, it was recognised that some effort would have to be expended in such a task, and the guiding hand of the Propaganda Ministry was seen in the design of the WHW drives which had been invested with much hope in their ability to deliver results. ${ }^{2}$ In July 1933, the Propaganda Minister, Dr. Goebbels, was appointed by Hitler to take on the responsibility for the official Winterhilfswerk welfare campaigns of the NSV. While the NSV would be charged with organising the day-to-day running of the annual campaigns, it would be the Propaganda Ministry which would have the final say on every matter which related to the design and to the practical procedures of the WHW drives. This meant that the leader of the NSV, to a large degree, worked as Goebbels' deputy in relation to the WHW itself. There is no reason to believe that Hilgenfeldt was unduly worried by this arrangement and he seems to have had a good relationship with Goebbels who, in the spring of 1933, had supported and fostered the hopes and the plans of the new welfare organisation. ${ }^{3}$ No doubt the successful welfare measures undertaken in the early spring of 1933

1. Richard J. Evans, The Feminist Movement in Germany 1894-1933, London 1976, pp.1-9; Dahrendorf, Society and Democracy in Germany, pp.33-64.

2. See the activities of Goebbels and Hilgenfeldt in the spring of 1933, HA, 14/262 pp.188-210.

3. Ibid. 
influenced Goebbels' decision to undertake to mastermind the nation-wide Winter Aid drives which were to become such a familiar feature of life in the Third Reich. To some extent these drives would show the regime in its best light and engage the interest of many foreign journalists who, annually, reported to their readers abroad on the latest developments of the Nazi winter welfare measures. British readers were kept informed of the amounts collected from the German population, and journalists commented both on the social and the economic implications of these particular measures. ${ }^{1}$ There is no reason seriously to doubt the popularity of these drives, at least at first, for they were carefully designed to elicit the maximum degree of support from the nation as a whole, and they seemed to have been successful in persuading many to give of their time, and money, in the service of a 'good' cause. ${ }^{2}$ It is hardly surprising that the NSV has been largely identified with the WHW insofar as the welfare organisation itself has been viewed as consisting almost entirely of its Winter Aid section by some at least. ${ }^{3}$ Neither is it surprising that the few studies of the NSV

1. See British newspaper reports, Clippings Collection, Wiener Library.

2. See The Morning Post, 6th February 1934, article entitled 'British Winter Help in Berlin', which read:

'Members of the British colony in Berlin have been contributing in a variety of ways (including observance of one-dish Sunday) to Herr Hitler's Winter Help Campaign. For this good cause and that of the British relief fund, they rallied in large numbers in the Kurfurstendamm Theatre tonight to see an amateur performance of James Montgomery's comedy, "Nothing but the Truth"'.

3. Both Grunberger and Bramsted rightly emphasise the importance of WHW but leave the strong impression that NSV welfare was epitomised by the WHW. See Bramsted, Goebbels pp.102-105; Richard Grunberger, A Social History of the Third Reich, London 1971, pp.100-110. 
which exist, and which deal with its pre-war development, tend to emphasise the WHW at the expense of its other measures. ${ }^{1}$ The glamourous side of the WHW, and its relative independence from the problems of Party and state, renders it an interesting, though, one can argue, a less truly representative aspect of NSV welfare as a whole. The Winter Aid scheme was the NSV (and the regime) en fête. The WHW drive revealed the NSV's most 'attractive' aspect when, annually, all citizens were shown how the new Nazified charitable schemes were meant to support the growth of national consciousness. Goebbels certainly seems to have been successful in catching the interest and the imagination of many who saw in the WHW an expression of the regime's less cruel side, but it was an aspect of Nazi rule which sought to legitimise claims presented to the nation in the form of a demand to give support to the new leadership. ${ }^{2}$ The design of all the propaganda material came under the control of Goebbels and his ministry and would remain so until the end of the war. ${ }^{3}$

The speed with which the first campaign of the first WHW was set up - the nation-wide scheme was in complete working order after only a few weeks' preparation - suggests that a real sense of urgency accompanied the frequently stated expressions of concern for the numbers of the unemployed and for those who were receiving neither social insurance benefits nor any other relief payments of any type

1. This may be largely unavoidable when studying NSV activities in the period up to 1939. See de Witt, 'The Nazi Party and Social Welfare', see also,T.de Witt, 'The Economics and Politics of Welfare in the Third Reich', in Central European History, 1978, pp.256-278.

2. See letters of thanks from the Reich Chancellery to Herr Carsten Wilhelm Bruening and three associates of Mérida in Venezuela for the donation of RM 1,000 for the WHW fund, BA, R43ii/564, 26th January to 8 th February 1934.

3. NSV History, HA, 14/262, p.306. 
whatsoever. $^{1}$ The organisation of the WHW operated through Gau, Kreis and Ort levels, with the Gauamtsleiter, Kreisamtsleiter and Ortsgruppenleiter of the NSV being responsible to Hilgenfeldt for all WHW activity in their areas. A Reichsarbeitsgemeinschaft was set up in 1933 which included agencies of Party and state, as well as the churches, the Deutscher Caritas Verband and the Deutsche Evangelische Kirche. ${ }^{2}$ A Reichsbeirat was also formed which included important Party leaders and others but this body seems not to have had any particular role, rather it was a means of engaging the interest of leading party figures in the Winter Aid scheme as a whole. While the collections started in October of each year, the work of the WHW actually began on lst July so that all administrative matters could be dealt with before the start of the winter. By September all the necessary forms were ready to be given out to the Ort offices, and by the sixteenth of the month, the organisation of coal distribution was being undertaken in offices at every level, from Gau to $0 r t .{ }^{3}$ Registration had to be made by certain dates in the autumn so that by the beginning of October, coal vouchers were ready for collection. All this work involved a complicated procedure at each level and no doubt kept all NSV staff fully occupied with WHW administration. The end of the business year occurred on 30th June which mean that the work of WHW administration continued virtually throughout the year from lst July to 30 th June the following year. ${ }^{4}$

1. Reher, Social Welfare, p.12. For a description of the whole operation see BA, NSD 30/34, Allgemeine, Arbeitsanweisung(2), 'Grundlage der Betreuung', p.21.

2. Ibid., 'Reichsarbeitsgemeinschaft des WHW 1936/37', p.23.

3. Ibid., 'Kohlenversorgung', pp.52-67.

4. Ibid., 'Terminkalender', p.77. 
For an unemployed person to obtain food or coal vouchers, it was necessary to register with the local Arbeitsamt for employment, for only then would the necessary registration card with a red WHW stamp on it be allocated. No WHW aid would be given out to the unemployed unless they could produce such a card. ${ }^{l}$ Not surprisingly, an individual's ability to refuse unpalatable work was severely limited by the rules and the regulations surrounding WHW aid. Welfare would be withheld if work was not taken up when offered by the local employment office. Public welfare offices and the local employment offices provided the WHW with the necessary information on welfare recipients and the unemployed, but low paid workers would have to furnish proof of their earnings before aid would be given. The amounts which could be earned while receiving WHW welfare seem to have been not more than 75 marks per month for couples and 50 marks per month for single people. ${ }^{2}$ The Blockwalter, too, had to give time to WHW administration in that he was expected to provide information about WHW recipients, either by bringing needy families to the notice of the WHW officials, or by reporting on those who were habitual drinkers or were otherwise deemed to be anti-social in character and therefore considered unsuitable to receive welfare assistance from the WHW. ${ }^{3}$ Only a very few Jewish people were allowed to receive WHW aid, the levels of which seem to have been negligible. The so-called 'Jewish Winter Aid' (not to be confused with the WHW proper) only functioned until 1935, or thereabouts, to give the lie to stories abroad of Nazi ill-treatment of the Jews. This meant that German

l. Ibid., 'Grundlage der Betreuung', p.2l.

2. St. J., 1936, p.636.

3. BA, NSD 30/34, Allgemeine Arbeitsanweisung(2), p.26. 
diplomats abroad could truthfully assert that Jewish people were receiving Winter Aid. Therefore it was entirely accurate for a German diplomat to claim as he did, in the Manchester Guardian in 1935, that, 'As many as 38,053 Jews ... were assisted by the WHW in 1933-34'. ${ }^{1}$ No figures so far have yet been discovered which relate to the pre-war Jewish Winter Aid, for these were not included in the official Rechenschaftsberichten. ${ }^{2}$

When Goebbels declared that by coming to the aid of the poorest members of the nation, the leadership showed, 'by deed that the concept of the People's Community was not an empty phrase', ${ }^{3}$ he was making a direct appeal for support, of the unquestioning variety, which still had to be gained. The population still remained to be informed, and to be persuaded, of the importance and the significance of the new government's measures. The social policies of the regime, as they were reflected within the welfare organisation itself, were designed with the purpose of gaining support from the majority of the German people. There seems no doubt that Nazi welfare measures, of which the WHW was only one, were created with such aims in view. ${ }^{4}$

From 1933, the German population was subjected to an intensive publicity campaign which was designed to elicit contributions from the public for the WHW scheme. Large sums of money were collected and then redistributed among the needy in the form of goods, such as food, clothing and fuel. However, it must be stressed that WHW aid

1. See The Manchester Guardian, 14th June 1935.

2. BA, NSD 26/261, 'Aufkommen und Verwendung', see part one.

3. Unger, The Totalitarian Party, p.208.

4. Reher, Social Welfare, pp.3-4. 
was not meant to replace other welfare payments from the state, or the insurance funds: rather, WHW aid was intended to be in the nature of a generous supplement from the community to those who, in spite of their existing incomes, were severely short of the basic necessities. ${ }^{l}$ The principle items of WHW aid were usuallycoal and potatoes, though warm clothing and domestic linen (not necessarily new) were distributed to those in most need. Other basic necessities were also available including cod-liver oil for children, groceries and non-perishable foodstuffs; these items were taken out of the donations of the 'pound-weight' of goods which were collected once a month during the WHW drive, and held in store for later distribution. ${ }^{2}$ In other words a massive collection drive took place every winter which included, apart from the street collections of money, the organising of a collection of goods for later redistribution. Not only this, but it was possible to obtain a meal in NSV canteens especially designed for dealing with those who were not in receipt of welfare payments of any kind, this being especially urgent during the winter of $1933 / 34$. In Berlin this measure seems to have been of some importance, with 4,000 free (or cheap) hot meals daily being obtained throughout the winter from twenty NSV canteens in the city. ${ }^{3}$ Funds amounting to RM 427,000 altogether from the first WHW campaign in Berlin were set aside for this particular

1. BA NSD 30/34, Allgemeine Arbeitsaweisung(2), pp.26-27.

2. Ibid., 'Pfundspende', p.46.

'Obst und GemUseversorgung', p.46.

'Versorgung mit Kleidung', p.49.

3. BA, R43ii/564, 'Tutigkeitsbericht Uber das Winterhilfswerk im Gau Gross-Berlin', 12th January' 1934. 
measure. The size of the economic and social problem in Berlin at this time is shown by the number of free meals which were distributed, which amounted to 228,331 during the period from November 1933 to the middle of March $1934 .^{l}$ This important welfare facility was provided by the NSV together with the other private agencies for welfare, who received a sum of money from WHW funds to enable them to assist the NSV/WHW in this particular measure. ${ }^{2}$ At the beginning of the Berlin WHW action the number of the destitute came to $1,324,969$, and the existing public welfare offices of the city of Berlin kept the NSV informed of the numbers of persons no longer in receipt of welfare or unemployment assistance. ${ }^{3}$ The total value of the first Berlin WHW action came to RM $15,703,496 .^{4}$ This total included donations of goods as well as small sums of money. Altogether food vouchers worth RM 3,882,253, along with 899,957 cwt. of potatoes and 1,664,399 cwt. of coal, were available for distribution from the end of December 1933 through the Berlin WHW action. ${ }^{5}$

Throughout the winter months collections for the WHW were not restricted to the frequently proffered collecting tin which made its appearance on the streets on certain days and between certain specified hours, and which were carried by members of the SA, the

1. Sozialismus der Tat-Das Buch der unbekannten Kämpfer der NSV Berlin. Amt fur Volkswohlfahrt, Gau Gross-Berlin 1934, Berlin 1934, p.72.

2. Ibid., p.72.

3. BA, R43ii/564, 'THtigkeitsbericht WHW, Berlin', p.3.

4. Ibid., p.5.

5. Ibid. 
police, the Wehrmacht, members of the Nazi organisations and NSV voluntary helpers: it was reported that the numbers of the NSV helpers amounted during the first drive to as many as $1,500,000$, all of whom were untrained and quite inexperienced in such work. ${ }^{l}$ Indeed, the street collections were only one of a number of methods used to part citizens from as much as they could spare. Other methods used were classified under the following headings:

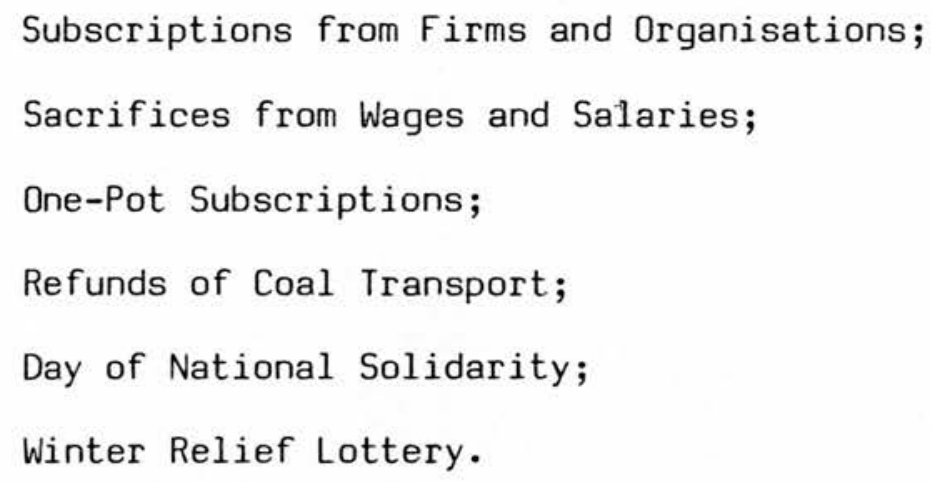

The first two items on the list referred to the so-called 'voluntary subscriptions', which were, in truth, a method of disguised taxation which none could easily avoid. Significant sums of money were collected in this way with as much as RM $77,739,075$ being received from 'Sacrifices from Wages and Salaries', in the Reich winter collections of $1934 / 35 .^{2}$ Clear guidelines were given abaut the percentage which could be taken from wages and salaries for WHW funds. ${ }^{3}$ The total sum collected for that year for the WHW came to RM $367,425,484 .^{4}$

A description of a typical Winterhilfswerk weekend which was

1. Reher, Social Welfare, p.12.

2. BA, R43ii/564, 'Rechenschaftsbericht WHW 1934/35', p.6.

3. BA, R2/4867, 'Winterhilfswerk 1940/41', 'Berechnungstabelle fur das Opfer von Lohn und Gehalt', this amounted to 10\% of the monthly deduction of tax or a monthly donation of 0.25 RM if no tax was paid due to a small income.

4. BA, R43ii/564, 'Rechenschaftsbericht WHW 1934/35', p.6. 
given in the Daily Telegraph of 6th March 1939 read as follows:

\begin{abstract}
'Regular monthly collections are made throughout the Reich in the streets, trains, shops, restaurants and hotels by thousands of uniformed Nazis armed with scarlet collecting tins. The collections usually begin in the streets on Friday night and extend over Saturday and Sunday. The purchase of one of the badges sold is no protection against further demands by collectors who continue to rattle their money boxes long after they have disposed of all their badges. During a recent collection I was approached over 150 times in the street, in trains and in restaurants. Shopkeepers and householders are subjected to periodic visitations by collectors, a nuisance from which they can only free themselves by commuting for a lump sum, thus obtaining the right to stick a numbered "Collecting ban" on their door'.
\end{abstract}

But the Propaganda Ministry was well aware of the disruptive effects of the overt use of force during collection drives and its officials were obliged time and time again to remind the local Party offices of the, 'ever-increasing gross infractions of collection procedures'.

It was pointed out that:

'By employing pressure, the local Party Leader builds a Potemkin Village for his superiors and ultimately for the FUhrer himself'.

It can be argued that the efficacy of the collections and the campaigns of the WHW, as a means of persuasive communication with the population, is open to doubt due to the methods used during the collections. For example, one local study points to the deterioration of the collection procedures through over-zealous practices such as the flooding of a ten minute tram route with as many as eight to ten collectors who could ask for successive donations from the unfortunate captive passengers. ${ }^{3}$ In this local

1. See article in The Daily Telegraph, 6th March 1939.

2. Unger, The Totalitarian Party, pp.209-210.

3.J.H. Grill, 'The NS Volkswohlfahrt and the Winterhilfswerk', in The Nazi Movement in Baden 1920-1945, London 1983, p.590. 
study of Baden, it was shown that the collections themselves, whose significance was all important for the dissemination of propaganda, were sometimes abandoned in favour of direct contributions from firms in order that the Kreisleiter might fulfil his statistical quotas. ${ }^{1}$ Such tactics became increasingly counter-productive, as Schwarz came to fear during the war when he believed that all enthusiasm for the WHW had been dissipated as a result of the increasingly aggressive procedures employed during the collection drives. ${ }^{2}$ Support and enthusiasm for the WHW drives were entirely ruined through the over-assiduous collection practices in the various Gaus, of which the NSV was aware, but powerless to prevent. Even though each WHW campaign was given full propaganda treatment, with the opening of each campaign being undertaken with the maximum publicity and press coverage, ${ }^{3}$ it is not difficult to imagine that a growing lack of trust may have accompanied the realisation that one was obliged, time and time again, to donate sums of money to the WHW fund when requested to do so, often enough by forceful-or even aggressive collectors. As Unger has pointed out, before the war it was feared that the effect of carefully prepared propaganda would be altogether lost through the actions of officials and volunteer helpers who allowed an abrasive manner to override persuasive methods. However, given the very large numbers of voluntary helpers and others who turned out to assume the duties of an official collector for the WHW, it is difficult to see how this problem could have been prevented.

1. Ibid.

2. See Chapter Seven.

3. However, in 1941, it seems that Hilgenfeldt considered lengthening the period of the WHW drive believing that it would not be an unpopular move, see Hilgenfeldt to Ley, 8th April 1941, BA, NS22/750. 
For example, in the winter of $1934 / 35$ as many as $1,338,335$ helpers were used to carry out the various duties in each of the months from October to March. ${ }^{1}$ of this number, 515,617 belonged to National Socialist organisations and formations, the rest consisted of voluntary helpers, of whom only 5,198 actually received some small payment for their work. ${ }^{2}$

The Winterhilfswerk drives were intended to provide a show of public activity in the service of the Volksgemeinschaft, and even if the activities of large numbers of voluntary helpers and others were difficult to control and to direct in some instances, they were, above all, ideologically necessary as a symbol of the participation of citizens in the nation's work. WHW activities, which included as a part of their design the active participation of numerous individuals, were perhaps aided by the lack of opportunity for taking part in social clubs and societies which were not under Nazi control. Even at the level of sports clubs or sewing clubs, the process of Gleichschaltung had virtually destroyed the opportunity for privately organised leisure activities. It may have been that the WHW could gain from this, given that people were sometimes willing to become involved in NSV work, or WHW work, even when they shunned other Nazi organisations. Certainly the levels of the membership of the NSV may have reflected this point, with a growth in membership by 1937 or 1938, showing that some people were prepared to participate, even if it was only for a few evenings in the winter, in welfare work for

1. BA, R43ii/564, 'Rechenschaftsbericht WHW 1934/35', p.4.

2. Ibid. 
the nation. ${ }^{l}$ It was hoped that more and more individuals would give of their time, especially in the winter months, making badges, crotcheted rossettes and other knick-knacks to be sold on the streets during the WHW street collections.

WHW activities also included entirely light-hearted ones, with concerts and musical evenings taking place in community halls and elsewhere, the entrance fee to which was donated to the WHW. The famous 'Day of National Solidarity' was itself designed as a huge spree, and marked the highspot of the whole Winter Aid Drive. On this particular day, always a Sunday, when Party leaders themselves were expected to turn out and do their share of collecting, famous film stars and well-known actors and actresses also gave their services as collectors and proved to be a great attraction for the Berlin crowds. The first of these occasions was a huge success, it attracted thousands of people into the centre of Berlin where the crowds grew so dense outside the arc-light illuminated front of the Adlon Hotel that it was almost impossible for the cars of the star attractions, Geobbels and Goering, to make any headway. ${ }^{2}$

1. Althaus, NS-Volkswohlfahrt, p.42.

Figures given for membership as:

$\begin{array}{rr}\text { December } 1933 & 112,000 \\ 1934 & 3,721,000 \\ 1935 & 5,050,000 \\ 1936 & 6,418,000 \\ 1937 & 7,942,000\end{array}$

Altgelt, Wegweiser, p.36 for a pictorial outline of growth in membership of the NSV during 1934-1935, $B A$, NS26/261, the number of voluntary helpers is given as $1,213,091$ for $1941 / 42$.

2. See The Evening Post 'Winter Help Fund Scenes', 10th December 1934, see Clippings Collection, Wiener Library. 
Among other measures which included a strong propaganda element with a money-raising function, was the somewhat eccentric (for so it was viewed in the foreign press) Eintopfgericht or Eintopfsonntag. On the first Sunday of each of the winter months the entire population was urged to restrict the traditional Sunday meal to one dish only. It was expected that a simple meal, possibly a stew, or some other type of simple and inexpensive dish, would be served on this particular day. The money which would have ordinarily been spent on a more typical German Sunday dinner was intended to be donated to the WHW. ${ }^{l}$ The sums collected by this means during the first Berlin Winter Aid drive were as follows:

$\begin{array}{ll}\text { October } 1933 & \text { RM } 154,022 \\ \text { November } 1933 & \text { RM 380,076 } \\ \text { December 1933 } & \text { RM 424, 495 } \\ \text { January 1934 } & \text { RM 411, 722 } \\ \text { February 1934 } & \text { RM 417, 906 } \\ \text { March 1934 } & \text { RM 420,757 }\end{array}$

The figures given above refer only to the sums collected from households, for not only did private citizens donate a part of the cost of a typical meal to WHW funds, but so also did hotels and restaurants which were instructed to hand over part of the payment for the meals served on Eintopfsonntag. The amounts to be donated by individuals were strictly laid down according to income and family commitment, and an article of 2 nd November 1934, in the v8lkischer Boebachter drew attention to the spirit in which the donations were

1. Sozialismus der Tat, pp.66-72.

2. $\mathrm{BA}, \mathrm{NSD} 30 / 34$, 'Eintopfspende', in Allgemeine Arbeitsanweisung (2) pp. 33-35. 
to be given and also the precise amounts. ${ }^{1}$ The levels of the donations were given as 50 Pfennigs per person in families where no children were present; families with children would pay half that amount per person while on no account would kinderreiche Familien pay more than they could afford. Hotels and restaurants were expected to charge the usual amount for a meal but to serve a simple dish and donate the entire payment less 50 Pfennigs to the WHW. ${ }^{2}$ Collections by the NSV officers of the Opfersonntag donations were made during the day and had to be delivered to the Kreis office and thence to the Gau office, at the latest by $8 \mathrm{p.m}$. on that day. Careful arrangements were made in order that no misuse of funds might occur, though the opportunity for this existed, as the WHW officials knew only too well. 3 Altogether the Gau Gross-Berlin collected RM $2,285,882$, from households and restaurants during the winter of $1933 / 34 .^{4}$ The sum received for the whole of the Reich in 1934/35 for this particular measure amounted to RM 29,581,378, while the 'Day of National Solidarity', yielded the smaller amount for the whole Reich

1. VB, 'Eintopfgericht ist Ehrenpflicht', 2nd November 1934:

All fellow citizens this Sunday must stand together in 'readiness to serve' ... all fellow citizens who have an income of over 200 marks must donate an appropriate sum on 'one-dish Sunday', see Clippings Collection, Wiener Library.

2. Ibid.;

Sozialismus der Tat, pp.65-67.

3. Ibid., pp.66-67;

BA, NSD30/34, Allgemeine Arbeitsanweis ung(2)

'Statistik', p.75.

4. This figure of $\mathrm{RM} 2,285,882$ is listed on the front of the first page of 'Sozialismus der Tat', and the figure of RM 983,433 was received, by the beginning of December, in the Gau Gross-Berlin: see 'Thtigskeitsbericht, WHW, Berlin', BA, R43ii/564, p.5. 
of $\mathrm{RM} 4,021,593 .^{1}$

The British Press responded to the idea of Opfersonntag (one-dish Sunday) with a certain degree of amusement, and even some amazement, with The Times printing an article entitled 'Stew Sunday in Germany'. ${ }^{2}$ Perhaps Goebbels' sense of Schadenfreude should not be discounted, for Opfersonntag seems to have been his idea entirely. Not only were the more prosperous members of the community expected to eat less on this day, but they were required to pay for the dubious pleasure of doing so. The one-dish meal was, it seems, intended to be a symbolic gesture which would serve to 'unite' the whole community on one particular day, each citizen would, so to speak, be breaking bread with his fellows. He was expected to call to mind his fellow Volksgenossen who were less well off, and who were in need of the donation which would be given to the WHW collectors. Propaganda material included the idea of having an 'invisible' guest at the table (namely those who would receive the benefit accruing from the donation), indeed, one's fellow-citizen. Sentimental poems were included in the propaganda material which was supplied to the press for publication. ${ }^{3}$ Articles, photographs and headlines were also given to the press, and three of these included:

Break bread for the suffering brother. Housewives-mothers - complete the work of the Fuhrer. Every household is a part of the National Community.

1. BA, R43ii/564 'Rechenschaftsbericht 1934/35', pp.6-7.

2. See reports of the British Press in the Wiener Library Clippings Collection.

3. See Ewiges Deutschland, NSD 30/7/8/9. A typical poetical expression of Eintopfsonntag read:

'Du weist es nicht, wer ich wohl sei Du hast mich nicht gesehen Und wirst doch merken wie wir zwei einander gut verstehen.

4. Bramsted, Goebbels, p.103. 
In the same article the housewife was urged to see to it that, 'when the results come in (of the sums collected) the FUhrer will be filled with joy because sixty million hearts will rejoice with him in their readiness for sacrifices'.

To this it must be added that it was more than some of the Party leaders were prepared to do, for when Hitler served at his own table the required frugal meal it was observed by Speer that the number of the guests shrank thereafter to two, or three at most. This provoked some sarcastic remarks from Hitler about the 'spirit of sacrifice' among his associates. ${ }^{1}$

The WHW faithfully published figures with regard to income and distribution, and the latter figures were given in a fairly detailed form. The vylkischer Beobachter always gave a long report on the WHW campaign at the end of the winter, listing long columns of the types of goods received and the value of these. ${ }^{2}$ Certainly the population was kept informed as to how much they had contributed; indeed, they were usually reminded of these sums in terms of 'proof' of support for the regime. ${ }^{3}$ The sums of money received by the WHW between 1933 and 1941/42 were as follows:

$\begin{array}{ll}1933 / 34 & \text { RM } 358,136,000 \\ 1934 / 35 & \text { RM } 367,425,000 \\ 1935 / 36 & \text { RM } 364,499,000 \\ 1936 / 37 & \text { RM } 415,151,000 \\ 1937 / 38 & \text { RM } 418,988,000 \\ 1938 / 39 & \text { RM } 566,352,000 \\ 1940 / 41 & \text { RM } 680,717,000 \\ 1941 / 42 & \text { RM } 916,240,000\end{array}$

1. Albert Speer, Inside the Third Reich, London, 1970, p.120.

2. VB, 11.10.34; 17.4.37. See Clippings Collection Wiener Library.

3. Ibid., VB, 'Mobilmachung zum WHW', 7th October 1936.

4. BA, NS26/261, 'Aufkommen und Verwendung', p.5. 
These figures expressed as a percentage of the national income were as follows:

\begin{tabular}{|c|c|c|}
\hline & $\underline{\text { N.I. }}$ in 1000 & \%WHW \\
\hline $1933 / 34$ & $46,514,000$ & 0.76 \\
\hline $1934 / 35$ & $52,710,000$ & 0.69 \\
\hline $1935 / 36$ & $58,662,000$ & 0.62 \\
\hline $1936 / 37$ & $64,884,000$ & 0.63 \\
\hline $1937 / 38$ & $72,590,000$ & 0.57 \\
\hline $1938 / 39$ & $82,098,000^{*}$ & 0.68 \\
\hline $1939 / 40$ & $89,787,000^{*}$ & 0.75 \\
\hline $1940 / 41$ & $92,482,000^{*}$ & 0.99 \\
\hline $1941 / 42$ & $97,825,000^{*}$ & 1.24 \\
\hline
\end{tabular}

*Altreich only (1)

A comparison of the amounts received in respect of the Opfersonntag and the Reich street collections is as follows:

\begin{tabular}{lrr} 
Year & Eintopf/Spende & $\frac{\text { Reich Street }}{\text { Collections }}$ \\
\cline { 2 - 3 } $1933 / 34$ & $25,129,000$ & $5,896,000$ \\
$1934 / 35$ & $29,581,000$ & $8,471,000$ \\
$1935 / 36$ & $31,967,000$ & $18,409,000$ \\
$1936 / 37$ & $33,737,000$ & $30,532,000$ \\
$1937 / 38$ & $34,742,000$ & $30,163,000$ \\
$1938 / 39$ & $50,462,000$ & $48,677,000$ \\
$1939 / 40$ & $81,560,000$ & $84,662,000$ \\
$1940 / 41$ & $163,706,000$ & $137,300,000$ \\
$1941 / 42$ & $236,987,000$ & $188,270,000$ \\
pp.13-14. & & \\
\hline .6. & &
\end{tabular}


It is clear from the sums given above that while the street collections until 1938 lagged behind the donations from the Eintopf Sunday collections in the amounts achieved, the street collections certainly picked up in the first year of the war. This was certainly due as much to increased efforts by the WHW as to popular support for the Nazi leadership. However, Hilgenfeldt himself seemed to derive some comfort from what he viewed to be 'evidence' that a majority of the population were, at the very least, not implacably against the measures of the government at this time. ${ }^{1}$

According to the figures published by the WHW, as a result of the 1934/35 WHW Drive, 211 persons out of every 1,000 were allowed some form of WHW aid. ${ }^{2}$ The amount received by each family, representing the entire winter donation in terms of value, came to approximately 30-40 marks. ${ }^{3}$ It should be stressed that the published figures make it difficult to assess the precise amounts which were distributed, for at all times only gross figures are given. The numbers of aided families, and numbers of children in each family, is given as follows for 1935/36:

1. The 'success' of the WHW which the NSV claimed could be gauged by the amounts collected came into serious question both before and during the war, see Schwarz to Bormann on the collection procedures of 1942, 15th December 1942, BA, NS22/751.

2. BA, R43ii/564, 'Rechenschaftsbericht WHW 1934/35', p.4.

3. C.W. Guillebaud, The Social Policy of Nazi Germany, London 1941, p.99. 


\section{Numbers of Families by Family Size}

\begin{tabular}{|c|c|c|c|c|c|c|}
\hline & October & November & December & January & February & March \\
\hline Individuals & 780,511 & 864,175 & 904,864 & 919,919 & 920,843 & 915,380 \\
\hline $\begin{array}{l}\text { Couples/ } \\
\text { No Children }\end{array}$ & 885,813 & 955,745 & $1,015,200$ & $1,040,009$ & $1,046,140$ & $1,039,614$ \\
\hline $\begin{array}{l}\text { Families/ } \\
\text { l Child }\end{array}$ & 721,354 & 797,879 & 854,490 & 884,580 & 889,888 & 885,545 \\
\hline $\begin{array}{l}\text { Families/ } \\
2 \text { Children }\end{array}$ & 571,070 & 607,351 & 655,717 & 675,214 & 662,340 & 663,059 \\
\hline $\begin{array}{l}\text { Families/ } \\
3 \text { Children }\end{array}$ & 359,977 & 379,898 & 406,435 & 409,817 & 414,944 & 407,974 \\
\hline $\begin{array}{l}\text { Families/ } \\
4 \text { and more } \\
\text { Children }\end{array}$ & 402,914 & 439,664 & 465,223 & 475,207 & 476,165 & 467,649 \\
\hline
\end{tabular}

The average figure with regard to families and individuals receiving aid for the whole winter is given for the year 1935/36 as follows:

\section{$\underline{1935 / 36}$}

$\begin{array}{ll}\text { Individuals } & 884,283 \\ \text { Couples/no children } & 997,089 \\ \text { Families/l child } & 838,961 \\ \text { Families/2 children } & 639,129 \\ \text { Families/3 children } & 396,510 \\ \begin{array}{l}\text { Families/4 and more } \\ \text { Children }\end{array} & 454,456\end{array}$

For the year 1935/36, an average of 194 persons out of every 1,000 inhabitants received WHW welfare aid; that is, seventeen fewer than the previous year, when 211 out of every 1,000 inhabitants were given

1. BA, R36/1007, 'Rechenschaftsbericht WHW 1935/36', p.5.

2. Ibid. 
WHW aid. This figure would fall steadily, until the number of persons in every 1,000 receiving WHW aid in 1942/43 was reduced to 60 , these particular figures refer to the area of the Greater Reich. The numbers of individual households according to numbers of members per household, and also the numbers of children and young persons in total, and also by average monthly figures, are given in separate tables for 1942 and 1943 as follows:/ 


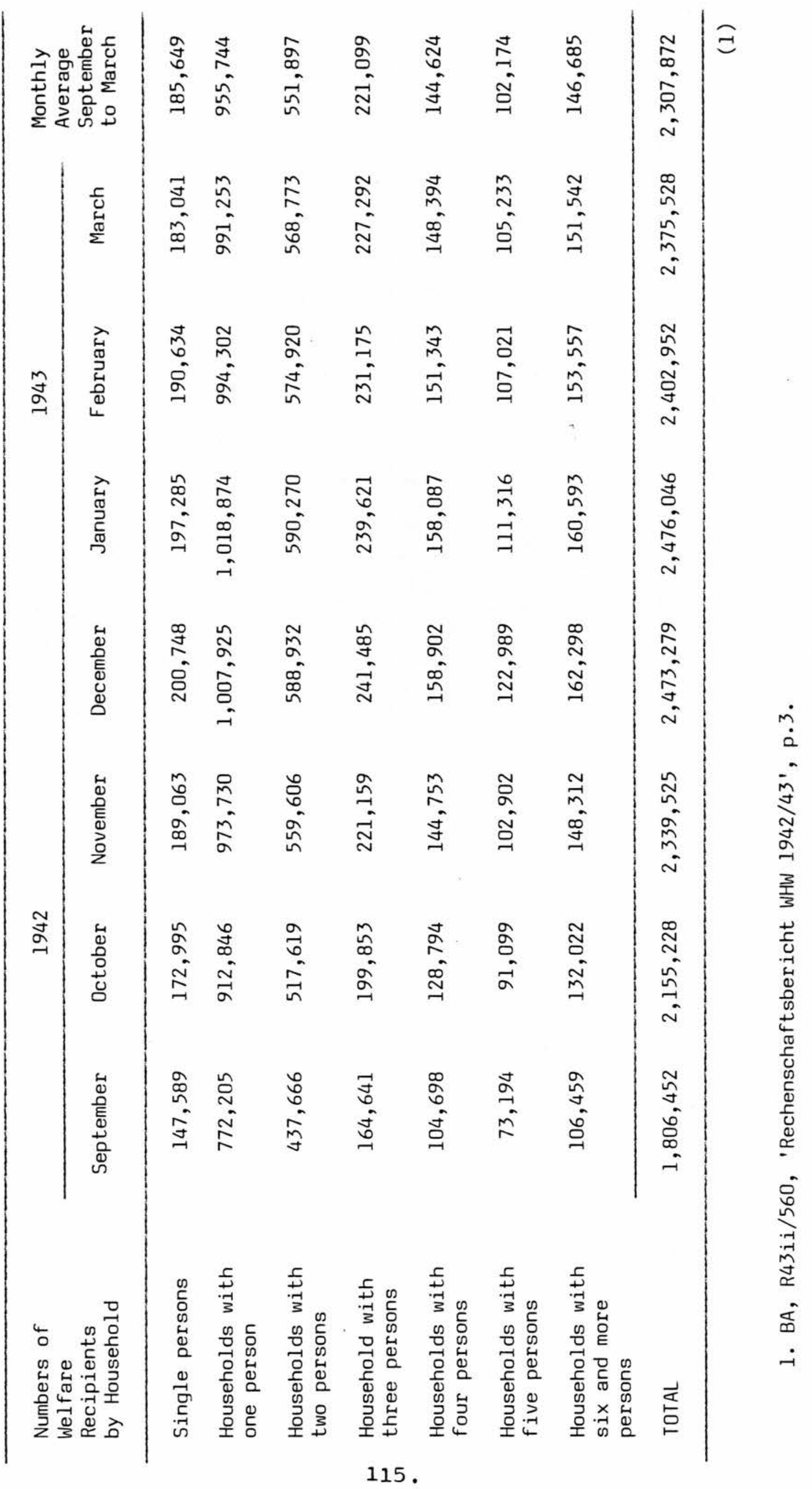




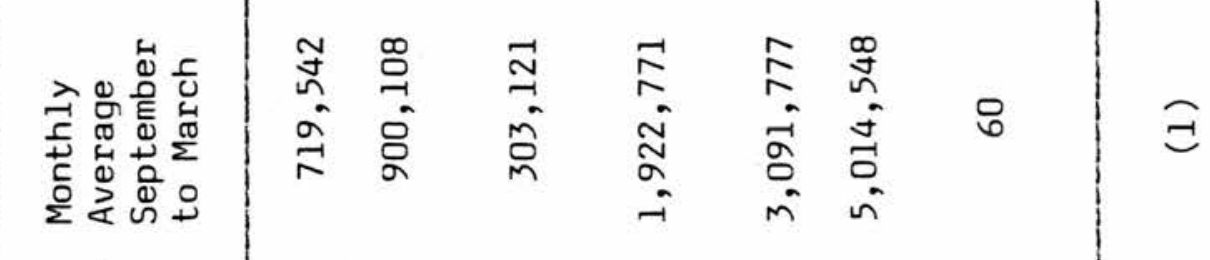

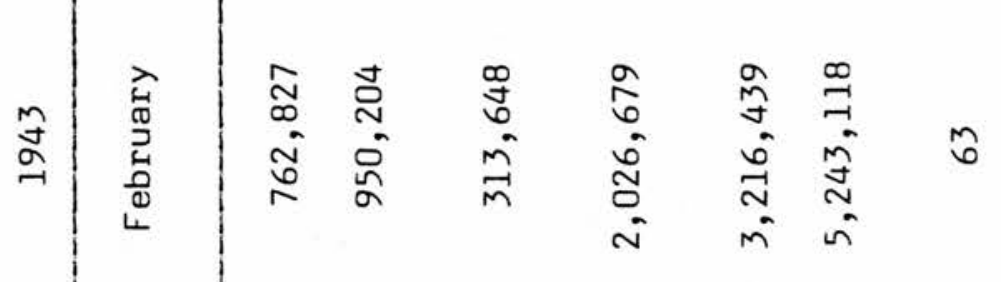

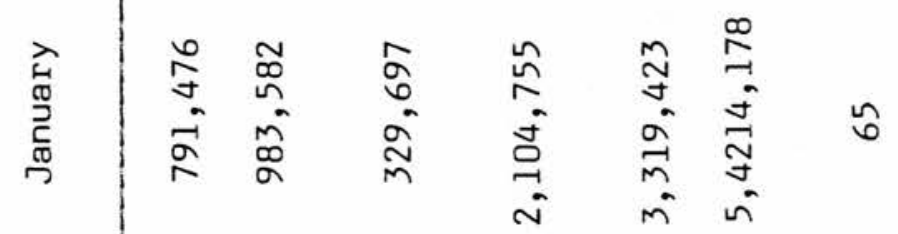

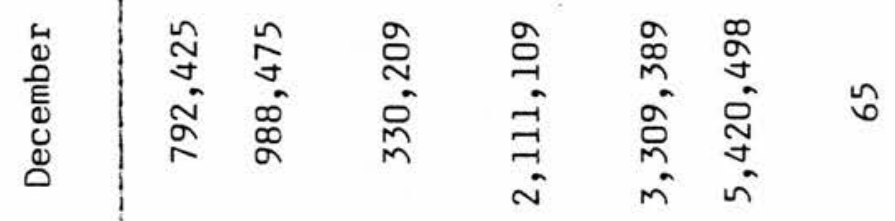

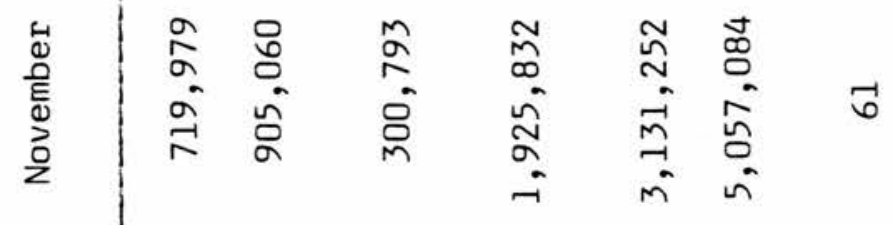

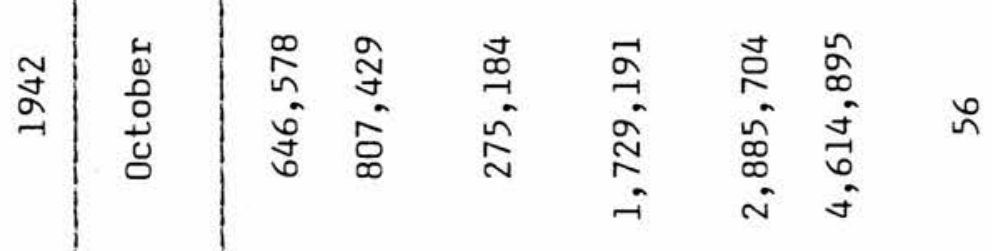

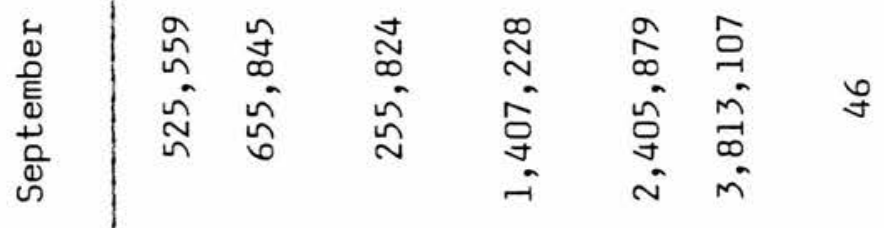

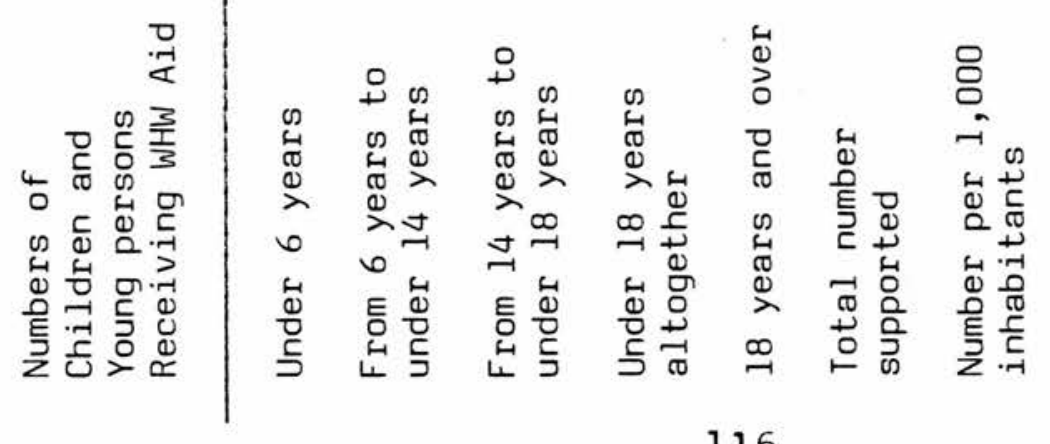


While it may be argued that the value of the goods received was modest, there seems little reason to doubt that for some at least, especially from 1933 to $1936 / 37$, the WHW supplement, which came as an addition to state welfare if that was proved to be insufficient, acted as a lifeline, seeing them through the months of the winter until a job could be found. ${ }^{1}$

Not only individuals and families received aid from WHW, for individual Gaus were also given assistance in order to ensure that adequate food supplies were available to provide for their populations. 2 The so-called Patengau or donator Gau system allowed for a regular exchange (and donation) of surplus food to be made. If necessary, certain Gaus were designated as distressed areas (Notstandgaue), if they were finding it hard to provide essential foodstuffs such as potatoes and flour. Other districts which could allow for an adequate supply for themselves, such as the potato-growing areas, were meant to provide for the surrounding areas, so that purchases of supplies of this commodity would be kept to within a specific district. The WHW, in other words would know which districts were able to supply this important food and which could not. ${ }^{3}$ Produce which existed as a surplus in certain Gaus was organised to provide for those areas in need of that surplus. In this way the industrial areas received from specified country areas produce which could be regarded as being in excess of need. The WHW made sure that these surpluses were distributed to certain areas, to which a regular donation would be made. The Gau Gross-Berlin could

1. BA, NSD30/34, Allgemeine Arbeitsanweisung (2), p.26.

2. Reher, Social Welfare, pp.13-14. $\mathrm{HA}, 1 4 \longdiv { 2 6 2 , \mathrm { np } . 3 3 3 - 3 3 4 }$.

3. Ibid. 
expect to receive supplies of rye flour from Kurmark, Mecklenberg, Pommern, LUbeck and Schlesien. ${ }^{1}$ Those areas which could provide for themselves without having to look for help outside the immediate vicinity, were as follows:

\author{
Bayeris che Ostmark \\ Koblenz-Trier \\ Kurhessen \\ Mittelfranken \\ MUnchen-Oberbayern \\ Mittelschlesien \\ Schleswig-Holstein \\ Schwaben \\ Unterfranken
}

The economic importance of the WHW was described by Werner Reher as enabling demand within the economy to rise through the important donations of necessary items in the family budget. This he argued released the spending power of low income families who could begin to purchase goods which otherwise would remain unsold. ${ }^{3}$ Help for the economy also came through purchases which were made on behalf of the WHW. In the Gau Sachsen for example, unemployed SA men received 2,130 pairs of shoes, 'of especially rugged quality' costing 22.50 to 28 marks per pair, and the same number of new suits; these items were all purchased through the WHW in $1935 .^{4}$ Many small

\title{
1. Ibid.
}

2. Ibid.

3. Reher, Social Welfare, p.18.

4. BA, NS/37ii/1062, Gau Sachsen, 'THtigkeitsbericht', March 1935. 
factories in Gau Sachsen had been given work because of the WHW whose funds were also used to purchase beds for kinderreich families (families with several children), so that as far as possible each child would have his own bed, an important measure to improve the general health of children in Germany. In Gau Sachsen in 1935, 3,200 beds were purchased and given to those most in need of them. ${ }^{1}$ Altogether, throughout Germany by the end of August 1937, as many as 897,725 beds had been distributed out of WHW funds:

'just under the number, of the entire population of NUrnberg and DUsseldorf together'.

The WHW also encouraged fish consumption throughout the country by purchasing and distributing this important source of protein. It seems that the WHW supported the fishing industry generally by buying up large stocks of fish which could be kept in cold store for later distribution. This amounted to nearly 3,000 tons in 1934/35, increasing steadily to 8,250 tons in 1935/36, and 9,350 tons in $1936 / 37 .^{3}$ Other goods which were purchased in large numbers included small porcelain badges which were then later sold in the streets during the collection drives. ${ }^{4}$ Firms such as the Staatliche Majolika

1. Ibid.

2. Leistungen der Nationalsozialistische Wohlfahrtspflege, p.10.

3. Reher, Social Welfare, p.17.

4. Ibid., p.19. See numbers of badges sold in 1935/36 by Gau, in BA, R35/1007 'Rechenschaftsbericht WHW 1935/36', p.19, this amounted to $71,537,377$ badges sold throughout the Reich during the Winter campaign; Ibid., 'Anzahl der verkauften Abzeichen bei den Reichsstrassensammlungen'. 
Manufaktur of Karlsruhe, could rely on large orders from the WHW. ${ }^{1}$ The coal industry too was supported by the WHW, which, annually, bought up large amounts for the purpose of free distribution to those in receipt of WHW aid. While Eintopfsonntag epitomised the altruism combined with practical aid which was supposed to inform the WHW as a whole, other practical measures were carried out on a large scale to meet the basic needs of impoverished fellow-citizens during the winter months. Distribution of coal certainly proved to be one of these and perhaps one of the most important measures of WHW, certainly before 1936. The organisation of coal distribution was achieved through a system of purchase by coal coupons which were themselves obtained from the WHW Ort offices. These coupons could then be exchanged for a hundredweight of coal or lignite briquettes, and were intended for household use only. The total number of such coupons issued during $1933 / 34$ was $8,000,000$. This, according to Reher, amounted to $16 \%$ of the whole domestic consumption of coal in Germany, and the average winter issue for each person was eight coupons (eight cwt. of coal). ${ }^{2}$ The method of payment to coal producers was as follows, the coal merchant delivered the coupons which had been handed in by WHW recipients to the local coal-distributing centre of the WHW, where he was given a payment voucher. He then passed the vouchers on as payment to the wholesaler, who could then pass on the vouchers to the coal

1. BA, R43ii/560, letter to the Director of the firm from Dr. Lammers with the news that two artists employed by the firm would receive a reward of the sum of RM 1,000 for their successful designs undertaken for the WHW badges, lst February 1940.

2. Reher, Social Welfare, pp.6-7. 
syndicate, which itself received payment in cash from the NSV. ${ }^{l}$ Understandably, the distribution of these goods involved expense and in order to save the WHW from having to exhaust its funds in meeting the cost of transportation, the railways, national and private, were required to transport goods for the WHW without cost. This service was regarded as a donation to the WHW, and expressed in the form of money value, it came to RM $17,525,980$ in $1936 / 37 .^{2}$

By 1936, WHW activities had become part of the familiar social scene throughout Germany, from collections in the streets to attendances at concerts, even though by this time, as the material given out by the Propaganda Ministry showed, unemployment had dropped considerably so that a large part of the original raison d'etre of the measure was slipping away. By 1936, it had become clear that the WHW would not diminish either in size or scope, for the sums collected would be earmarked for other important NSV schemes such as the 'Mother and Child' section of the NSV. ${ }^{3}$ The educative function of the WHW increased markedly from 1936, and it seems to have extended somewhat its range of options for the 'enlightenment' of the population, now including as it did, in the light of Goering's Four Year Plan, information and advice about the importance of autarky. ${ }^{4}$ In the Winterfeldzug (Winter Campaign) of 1936/37 the most obvious change, perhaps reflecting the drop in the numbers of the unemployed,

1. Ibid.

2. $B A, N S D 30 / 34$, Allgemeine Arbeitsanweisung(2), 'Frachtfreiheit', pp.68-69; Reher, Social Welfare, p.33.

3. BA, NSD 30/36, 'Aufkommen und Verwendung', 'WHW Zuwendungen fur andere Soziale Zwecke', p.12, in 1940/41 Mutter und Kind received RM 484,00,000 from the WHW.

4. BA, NS37ii/1058, 'Winterfeldzug', p.4. 
was the almost entire absence of references to 'socialism of the deed'. The title of this campaign was, 'We are building the basis of the eternal Germany', but without, in the course of the campaign of $1936 / 37$, having to continually stress the idea of the need to build 'socialism' as well. ${ }^{1}$ The five main themes of the $1936 / 37$ campaign were:

1. The spiritual foundation of the eternal Germany is National Socialism;

2. The German Folk of the future shall be healthy and able-bodied (wehrhaft, i.e. capable of bearing arms);

3. Securing self-sufficiency in food production and National Socialist economic superiority as the essence of the Four Year Plan;

4. The Wonder of National Socialism;

5. The ideal education of the people through the means of the Winterhilfswerk.

Photograpic slides provided for this campaign illustrated several themes such as:

1. Healthy parents, healthy children;

2. German racial policy;

3. Bolshevist subversive activity.

A film would also be provided, which was strongly anti-Bolshevist in intent and was inspired by the conduct of the civil war in Spain. This was shown under the title of 'Bleeding Spain'. The campaign programme included very detailed instructions from the Propaganda Ministry and it is clear that there was little opportunity for the

1. Ibid.

2. Ibid., p.2.

3. Ibid., p.5. 
NSV Gau officials to interfere by themselves contributing to the material as such. Goebbels' speech, given at the beginning of the campaign, was on 'Bolshevism in Theory and Practice', and it provided the material for the first set of brochures for the winter which went out to the Gaus. The Press too was given strict instructions about articles to be published. All reports and headlines would have to emphasise the general line of that year's campaign and its political emphasis. The main thrust of WHW propaganda in 1936 was meant to show the Party in the guise of the 'eternal' leader of the people towards the spirit of National Socialism. Other themes included, for example,

'A new Germany, thanks to National Socialist ideas and through National Socialist leadership, is in existence'!

And on National Socialism,

'One can love it or hate it, but no-one can alter it or remove it'.

The goal of National Socialism was described as being neither Marxist chaos nor bourgeois individualism, but the creation of a unified nation out of the previous disunity of Weimar Germany. ${ }^{l}$ Economic facts and figures were also to be stressed with information on the fall in unemployment and the growth of German industrial production. As time went on the WHW continued to stress the theme of the building of the community of the people and to set aside the original emphasis of 'socialism of the deed', though this term occasionally crept back in, in some of the articles in the NS-Volksdienst. 2

It might be argued nevertheless that the Propaganda Ministry was trying to do too much, given that the WHW was intended to foster

1. Ibid., p.5.

2. BA, NSD 30/1-4a, NS-Volksdienst, 1933-43. 
new attitudes with regard to some fundamental issues, such as the role of the citizen, the idea of 'real socialism', and not least, political indoctrination of a barely disguised variety. ${ }^{l}$ It certainly seems that in many ways the design of the WHW drives was too clever by half. Indeed, it may have functioned in a negative way through a determination to push really hard, to 'saturate' the perceptions of the population and, unintentionally, foster a tendency to blank out the message being delivered. This process would be only the first step towards popular disregard of the real function of the WHW as the Gauamtsleitung of the Gau Westfalen-Nord knew only too well. ${ }^{2}$ Collections for the charitable work of the Catholic church in this Gau in 1936 were far more successful than those of the NSV/WHW, much to the chagrin of the NSV officials. While such an example shows that the churches were effective in certain instances in encouraging people to show opposition to Party demands, in this case by a denial of support for the NSV and the WHW, it also shows how ineffectual the propaganda of the NSV and WHW had been in this particular area. This may have been all the more galling for the WHW/NSV in Berlin, given the special efforts undertaken in $1936 / 37$ for the WHW drive for that year. ${ }^{3}$ Nevertheless in Sachsen in many of the poorer areas, support for the welfare measures of the WHW was demonstrated. It may have been that, initially, the WHW was greeted with some general enthusiasm as one

1. Ibid.

2. RUdenhausen, 'NSV/Gau Westfalen-Nord', p.24l.

3. BA, NS 37/1058, 'Winterfeldzug', 'Sicherung der Nhhrungsfreiheit und die nationalsozialistische Wirtschaftsfuhrung als Inhalt des neuen Vier jahresplanes', p.2. 
local study of Baden has shown, but the example of Sachsen poses the question as to how strongly such support extended itself throughout the area of one entire Gau. Perhaps only detailed local studies might be capable of showing the nature and extent of support for NSV and WHW measures and plans. However the NSV's determination to gain popularity, with the help of the Propaganda Ministry which created the material for WHW drives, was shown in every effort made to elicit support.

As time went on, more and more money continued to flow into the coffers of the WHW, less and less of which actually went to the measures of the Winter Aid scheme; for they were, increasingly, transferred to othermeasures of the NSV, though any suspicions that WHW funds might be misappropriated were treated with care. When, in 1936, gossip began to circulate after a lavish party thrown by Goebbels on Peacock Island (at the time of the Berlin Olympics), a few days later the island was opened up to the public with decorations left intact, so that 'the German people' could enjoy the sight. ${ }^{1}$ This was meant to show that Goebbels had nothing to hide; although one wonders how such a condescendingly cynical attempt to allay suspicion of this type could have increased the public's trust in the WHW, or in Goebbels himself. The suspicion that Goebbels had used a part of these funds for his own purposes in 1936 was an entirely understandable one; but it was, it seems, based mainly on speculation and gossip circulating at that time. However, Martha Dodd herself seemed to think there may have been an element of truth in these suspicions of the misuse of the Winter Aid funds. On the other hand, the misappropriation of WHW funds by the recipients of

1. Martha Dodd, My Years in Germany, London 1939, p.203. 
WHW aid was treated very harshly indeed and in a highly visible manner. ${ }^{l}$ One unfortunate who had obtained $6 \mathrm{cwt}$. of potatoes for his family, but who sold the largest part to get funds to finance a drinking bout, was sentenced to one year's imprisonment in Dortmund in 1934. On the day of his arrest he was led through the streets of the city carrying a placard which described the nature of his crime, and to drive home the lesson, both to the culprit and his fellow-citizens, he was placed in a public square in the evening, in the beam of a search-light. ${ }^{2}$ Such an example must have been a powerful deterrent against the misuse of WHW aid.

The Beginning of War-time Winter Aid

From the outbreak of war in 1939, it was clear that the WHW would continue to play an important role and provide the funds for the provision of independent, or non-state welfare activity in Germany. Not only would the extremely visible and 'public' aspect of WHW remain - that is, the collection procedures would continue as before - but new collections undertaken in the summer months in support of war-time measures would be put into operation. ${ }^{3}$ One of the first activities of the WHW in 1939, just after war was declared, was to arrange to put into operation the directive of 13 th October 1939, which was signed by Hess, Hitler's deputy. ${ }^{4}$ This directive instructed that every Party organisation should fully participate in

1. BA, NSD 30/34, Allgemeine Arbeitsanweisung (2), pp.26-27.

2. See The Daily Telegraph, article of 29 th May 1934.

3. BA, NS 37ii/1055, letter from Hilgenfeldt to all Gaubeauftragten on co-operation of Party Organisations with the German Red Cross, 14th October 1939.

4. BA, NS 37ii/1055, 'Anordnung Nr. 195/39', from Hess, 'Zusammenarbeit der Parteiorganisation mit dem Deutschen Roten Kreuz', 13th October 1939. 
giving every support tothe Deutschen Roten Kreuz (DRK). It would fall to the WHW and the NSV alone, to arrange for the collections which would be held throughout Germany for the measures of the DRK. Through the WHW and the newly named Kriegswinterhilfswerk or KWHW, the DRK would be able to raise much needed funds by a direct appeal to the public, much as the peace-time WHW had previously done with some success. Similarly, donation, not taxation would finance part of the war effort in the same manner as it had financed the Party collections for welfare; from 1939, the WHW had the increased task of raising money for the German Red Cross. The first DRK collection drive took place in the spring and summer of $1940 .^{1}$ The drive was organised by the WHW under the title of Kriegshilfswerk given that it was to take place in the early summer and continue through June, July and August 1940. The entire action in aid of the DRK held under the auspices of the WHW, followed exactly the form of the normal WHW drive, though it was much reduced in size and scope. Indeed it was a miniature version of the WHW drive. ${ }^{2}$ The DRK drive was given an official opening in Berlin on 17th April 1940, and, following custom, Goebbels made a speech; no mention was made at this time of Hitler's personal attendance at the opening which may have taken place in the Propaganda Ministry, and it was not specified in the instructions distributed by Hilgenfeldt. ${ }^{3}$ Again, as was customary, the Goebbels speech heralded the official start of the campaign which was meant to swing into action on certain dates during the summer. From the

1. BA, NS 37ii/1055, from Hilgenfeldt to all Gaubeauftragten, 'Propagandaplan des Kreigshilfswerkes fur das DRK', 18th April 1940.

2. Ibid.

3. Ibid. 
instructions which had been worked out in the Propaganda Ministry, the campaign can be seen to have resembled nothing other than a massive advertising campaign for the DRK. House-to-house collections were intended to take place during April, May and June, numbering six in all, with two main street collections taking place at the end of June. ${ }^{l}$ the DRK would itself take an important part in the street collections and instruct its members to turn out on the special days indicated. After a short break it was intended that further house-to-house collections would be resumed, and the action would end with two further street collections in August. ${ }^{2}$ All WHW symbols would be removed from the collecting tins and were to be replaced by the letters 'DRK' for the duration of these collections. It seems that the WHW would continue to run these fund raising drives for the German Red Cross which was not itself allowed to undertake any fund-raising activity without the permission of the WHW. ${ }^{3}$ The directive from Hess made this quite clear. It was not however the first time that the WHW had organised a collection of funds for the DRK, but this had previously been undertaken on a very small scale within the WHW drive itself. However, future collections for the DRK from 1939 would be run like a WHW drive, but on a smaller scale. Far from being reduced in scope or in size in time of war, the WHW (now KWHW) would continue to operate fully. Income for KWHW for the year $1942 / 43$ seems to have amounted to RM $1,757,337,620 .^{4}$ So far,

1. Ibid., Section 3, 'Laufzeit, Träger und Terminplan der Aktion'.

2. Ibid.

3. BA, NS 37ii/1055, 'Anordnung Nr. 195/39, Section 3', 'Geld-und Sachspenden'.

4. BA, R43ii/560, 'Rechenschaftsbericht WHW 1942/43', p.5. 
however, no figures have been found which refer to the collections undertaken by the WHW for the German Red Cross during the war.

By $1941 / 42$ the WHW had a staff of 11,485 paid workers and could call on 1.2 million voluntary helpers. The amount which the recipients obtained at this time seems to have been (for the duration of the Winter), in terms of value of goods received 49.9 marks, ${ }^{1}$ an improvement of 10 marks over the previous year's figure. Thus out of every 1,000 inhabitants of the area of the Altreich, including the Generalgouvernment, 60 were in receipt of WHW assistance. War-tidme WHW was given only as the limitations of ordinary rations allowed. But, as before, vouchers for the payment of rent, gas and electricity accounts were allowed. During the winter of $1941 / 42,12.4$ million marks were distributed to expectant mothers and to large families in the form of non-rationed goods. Free meals were also available as were free film and theatre tickets. It seems that by this time the chief recipients of WHW aid were old people on fixed incomes, large families and widows of soldiers and their children, though WHW still functioned as a subsidy to low wage-earners in certain cases. ${ }^{2}$ According to one report it seems that at this time (1942) suspicions on the part of the general public were aroused about the activities of some WHW organisers, for it was becoming widely believed that they were encouraging the growth of the black market by auctioning off some of the scarce goods which had been collected, for very high prices. $^{3}$ However it seems that no very serious degree of grievance

1. Basic and Zonal Handbooks, Chapter 11, p.255.

2. $\mathrm{BA}, \mathrm{NSD} / 30 / 34$, Allgemeine Arbeitsanweisung, (2)

3. Basic and Zonal Handbooks, Chapter 11, pp.275-276. 
was held against the WHW at the time, though further investigation of this particular issue needs to be carried out. It must be remembered that the public had no means of ascertaining whether the funds which the WHW controlled were being used as reported in the press. Nevertheless, the WHW law of 1936

facilitated any actions against the mishandling of funds. From 1936 it was possible for the WHW itself to prosecute those who had been discovered to be mishandling WHW funds. ${ }^{l}$ The enactment of this law promised that the WHW had become a permanent feature of the Third Reich, and that the WHW had achieved the status of a state institution which, however, came under the direct control of the Party. $^{2}$ It had therefore developed into a hybrid, taking on, as it had, the character of a state institution and a Party agency, at one and the same time.

So far it has been impossible to discover how far and by how much WHW funds were directed towards re-armament and the war effort, though it has been suggested that WHW funds made significant contributions to both. ${ }^{3}$ It seems possible that the WHW had become connected in the minds of the majority of the population with 'Waffenhilfswerk' . 4 However, in 1940 Hilgenfeldt found it necessary to obtain a sum of RM 25,000,000 from Goering's Four Year Plan office in order to lay up a stock-pile of WHW coal. ${ }^{5}$ This does suggest that

1. BA, R43ii/564, 'Gesetz Uber das Winterhilfswerk'.

2. Aryeh L. Unger. 'Propaganda and Welfare in Nazi Germany', Journal of Social History, Vol. 4, No.2, 1970-71, p.134.

3. Kershaw, 'How effective was Nazi Propaganda?', p.189.

4. Kramer, Das FUrsorge system, p.191.

5. BA, R2/4867, Hilgenfeldt to the Finance Ministry, letter of 19th March 1940. 
funds may have been stretched too far for that year, and were not sufficient to cover certain war-time exigencies. Certainly, this point does not prove that WHW funds did not go to the war effort, though it is worth mentioning that after 1936 WHW funds substantially supported another NSV measure, the 'Mother and Child' Scheme. The subsidy from the WHW to the MuK (Mutter und Kind), rose year by year so that by 1940 , one half of all WHW income was diverted to the Muk. This proportion did not decrease, but rather, rose until nearly three-quarters of all income of the WHW was diverted to Muk in $1941 / 42 .^{1}$ The funds of the WHW had to support two charitable schemes of the NSV, not one, and there is good reason to believe that WHW funds were not earmarked for specific war-time measures. It certainly seems however, some NSV funds were, as Schwarz admitted in 1945, handed over to the Reich Chancellery and the armaments industry, though no specific reference at this time seems to have been made with regard to the WHW funds and their destination. ${ }^{2}$ Further investigation of these matters needs to be undertaken before a clear assessment of the mishandling of WHW funds can be made.

From 1933 the WHW was charged with involving itself within the general attempts by the Nazi leadership to drum up support for the Nazi regime. It can be held to have been successful in only a very limited way, and only at the beginning when unemployment was still very high; later, when many returned to work, the WHW must have been seen for what it was, namely, an ad hoc and informal means of taxing the population. From the start of the war it was clear that the WHW

1. BA, NS26/261, 'Aufkommen und Verwendung', p.21. See also Chapter Seven.

2. Kramer, 'Das FUrsorgesystem', p.194. 
would become more and more involved in helping the war effort, and it would be expected to support war widows and their children, which it seems to have done with some effect. However, it is unlikely that this task would engender much support for the regime in itself, being a constant reminder of the unhappiness of numerous individuals who had lost relatives in the war. Far from reducing in size or scope, the WHW continued to operate, taking up scarce manpower when this might have been regarded as wasteful and counter-productive in time of war. However, Goebbels would stubbornly cling to the idea that the WHW could provide the basis for a belief in the Volksgemeinschaft, which if nothing else, shows how persistent some, at least, of the Nazi leaders were in their own 'faith' in Nazi Germany. Perhaps Thomas Mann's view of the Winter Aid was one which many would quickly come to share; as he put it in the disry ${ }_{\wedge}$ entry of 28 th February 1934 ,

'this is again fraud and pretense like all the rest, a cheap semblance of democracy comparable to the charade of the "high-up" leadership's going out onto the streets to take up a collection for the Winter Aid campaign. Fake charity, a brilliant display of lying and clever advertising, in short, propaganda for its own sake like everthing else these counterfeits and bunglers dream up'.

1. Thomas Mann, Diaries 1918-1939, London 1984, p.199. 


\section{CHAPTER FOUR}

\section{MUTTER UND KIND}

NSV Welfare for Mothers and Infants

The Nazi Government's first priority in the realm of welfare provision was to meet the continuing and urgent claims of deprivation in yet another depression winter, 1933/34, through the first official WHW campaign. But in spring 1934 the NSV was able to turn its attention to another area which the regime perceived to be of urgent importance, the provision of advice and welfare for mothers with young children. This was to be dispensed through a new section within the NSV organisation, the Mutter und Kind (MuK) whose goal was the,

'promotion and furtherance of the erbgesunden (hereditarily sound) German family, but also unmarried mothers who will receive economic help and advice on all health matters'.

Goebbels firmly stated in 1934 that National Socialism sought to place the promotion of the bioligically sound race at the forefront of its actions and to promote the health of future generations. ${ }^{2}$ Welfare which was organised by Mutter und Kind (MuK) was restricted to that section of the population which could claim impeccable 'Aryan' descent. ${ }^{3}$ The setting up of the MuK was in effect a determined attempt to provide a nation-wide maternity service which

1. BA, NS 37ii/1035, 'Bericht Uber das Hilfswerk Mutter und Kind vom 1.4.34 - 31.12.34'. (Hereafter 'Bericht MuK').

2. Ibid., p.l.

3. BA, NSD 30/4a, NS-Volksdienst, December 1943, 'Zehn Jahre Hilfswerk Mutter und Kind', p.16l.

BA, NSD 30/3 NS-Volksdienst, July 1939, 'Mutter und Kind im Westgau',p. p.307-312 
would function differently from the earlier state and church-based provisions which had existed during the Weimar period. ${ }^{1}$ After 1933 , while state and charitable welfare would continue, the NSV's leaders intended that they themselves would eventually come to dominate the entire system of maternity and child care in Germany; the result was that, by 1938, over $60 \%$ of all existing maternity welfare clinics were run by the Muk. ${ }^{2}$ The most obvious differences between MuK and earlier arrangements lay in the extent to which the NSV's maternity care would be dispensed, or withheld, according to racial criteria or to the Nazi definition of 'asocial'. 3 There was, however, a slight softening of the harsh rules with regard to the latter category, when some mothers who were labelled 'asocial' (or Gemeinschaftsunfahig)

but who had very young children, were given help. This seems to have been given on a much reduced level and only in order that very young infants could have proper nourishment in the crucial first few months of life. However, it is not clear for how long, or in what amounts, such aid was given. Neither is it clear how many were helped, for this category does not appear in the official figures of Muk costs. ${ }^{4}$ All of this was entirely in line with general NSV

1. Friedlander and Myers, Child Welfare in Germany, pp.234-248.

2. BA, NS 22/457, 'Arbeitsbericht des Hilfswerkes Mutter und Kind fur das Jahr 1937/38', p.23. (Hereafter 'Hilfswerk MuK $\left.1937 / 38^{\prime}\right)$. By the end of December 1937, there were 24,478 advice centres visited by $3,573,486$ women.

3. BA, NSD 30/11, Informationsdienst March 1939, 'Gesunde Ehen', 'Gesunde Familien', 'Kampt den Erbkrankheiten', pp.100-101. HA, 13/259, 'Artikeldienst' 1/303/910, Hauptamt fur Volkswohlfahrt Presse'. 'Die NS-Volkswohlfahrt das soziale Gewissen der Nation', BA, NS 22/457, 'Hilfswerk MuK 1937/38', pp.1-22.

4. BA, NS22/457, 'Hilfswerk MuK 1937/38', pp.23-28. 
policy. ${ }^{1}$ While the new government wished to see the birth-rate climb, it did not allow this desire to weaken the resolve to see it climb qualitatively and not merely quantitatively. The Muk was intended, above all, to provide the means whereby the continuing decline in the German birth-rate would be halted. The fall in these figures, which had been steadily continuing since the late 1870s, was a matter which the new government in 1933 took seriously, not least because the rate of the decline had become sharper during the years of the Depression. ${ }^{2}$ The figure of 39 live births per thousand of the population in the late 1870s was reduced to 29 in 1910, and thence to the low figures of 15 per thousand in 1932 and 14.7 in $1933 .^{3}$

The pro-natalist policies of the Nazis had two aims: firstly, to halt the declining rate of births per thousand of the population, and secondly, to secure a significant rise in the numbers of live births. A pro-natalist policy would be supported by both the state and the Party and the provision of economic and welfare aid would themselves be presented within a framework of propagandaoriented schemes for the care of women and children. The NSV's

1. See Chapter Two.

BA, NS 37ii/1035, Bericht MuK, Section I, 'Allgemeines', see Goebbels' speech.

2. D.V. Glass, Population Policies and Movements in Europe, Oxford 1940, p.311. As Glass points out, 'Whereas in England and Wales the birth-rate followed a fairly steady curve between 1928 and 1932, the German rate turned downwards very sharply in 1930. But for the particularly marked depression the German birth-rate might have been about 16 per thousand in 1933, instead of the actual rate of 14.7 per 1,000 (live births) in that year'. See also St.J. 1936, p.35; W.R. Lee, 'Germany', in W.R. Lee (ed.), European Demography and Economic Growth, London 1979, p.166.

3. St. J., 1936, p.35. 
maternity care would be presented in the form of an appeal to achieve rational skills in child care and health care for pregnant and nursing mothers, but it would also carry the ideological emphasis on fertility and fecundity, and the need to have as many children as possible, for the good of the German race. ${ }^{1}$ To achieve a rise in the birth-rate however would mean securing the reversal of demographic and social trends which had become established at the end of the nineteenth eentury, not only in Germany, but in western Europe itself. ${ }^{2}$ A dramatic decline in fertility in Germany had set in which can be seen clearly by referring to the numbers of infants born to women of childbearing age between the years of $1910 / 11$ and $1933 .{ }^{3}$ From a figure of 128 live births per thousand of this age group in $1910 / 11$, the number of births dropped unrelentingly, reaching the low figures of the years 1930, 1931, 1932 and 1933, at 67.3;62.0; 59.5; and 58.9 respectively. ${ }^{4}$ Whatever the complicated reasons for this trend, for such it was, anxieties concerning these developments which surfaced during the Nazi period were only part of a longer search for the causes of the decline in births. ${ }^{5}$ In Germany during 1912 this

1. BA, NS 37ii/1035, 'Bericht MuK'. BA, NS 22/747, NSV propaganda instructions 'Rundfunkwerbung in den Gauen, Allgemeine Werbung fur die NSV-Arbeit'; NS 22/653, Arbeit, Volk und Staat: AuszUge aus Reden, Erklarungen und Aufsatzen Adolf Hitlers und seiner Mitarbeiter, Berlin 1938, p.37., The mother decides the fate of coming generations; by the numbers and the health of her children, stands or falls Germany's future'. Speech given by Frick on Mother's Day, 16th May 1938.

2. Glass, Population Policies, p.165. Lee, 'Germany', p.165.

3. St. J., 1938, p.47.

4. Ibid.

5. J.E. Knodel, The Decline of Fertility in Germany, 1871-1939, Princeton 1974, p.48. 
search had fixed itself upon the growth of the feminist movement blaming its emancipationist ideals for the fall in the numbers of births. In France, too, a developing pro-natalist viewpoint gave rise to an 'endless flood' of population propaganda which accounted for the decline of fertility by referring to a variety of causes, from socio-economic reasons to bicycle riding by women. ${ }^{l}$ Thus pessimistic pronouncements about the reasons for a decline in fertility were just as likely to be based upon non-rational as rational grounds. It seems clear that German fears were only heightened by the French example, and from 1911, there seems to have developed a growing anxiety that the German nation might be heading towards a similar lack of growth in the population, for in France the population had ceased to grow by the turn of the century. ${ }^{2}$ Certainly such fears were not groundless, given that by 1938, sixty-five of the ninety Départements of France showed an excess of deaths over births. ${ }^{3}$ These particular figures would alarm the Nazi officials of the NSV who wrote anxiously at that time of the folly of participating in policies which had been strongly influenced by the writings of Malthus. ${ }^{4}$

The population policies of the Nazi Government provided for measures which were all meant to support the drive towards a significant rise in the birth-rate. The state offered economic inducements on the one hand, while the Party, through the Muk,

1. R.J. Evans, The Feminist Movement in Germany 1894-1933, London 1976, pp.182-187; Glass, Population Policies, p.148.

2. Ibid., p.196.

3. Ibid., p.218, Note 2.

4. BA, NSD 30/11, Informationsdienst, November 1938, p.36. 
offered increased facilities for the care and well-being of pregnant women, infants and small children. Most importantly, the Muk would support, through the design of its welfare measures, an ideological emphasis which was meant to underline the new status of mothers whose role in the new Germany would be seen to be upgraded. Such desired alterations in the system of social esteem, and within the perceived attribution of social status itself, were ambitious to say the least, but perhaps were essential to ensure the achievement of at least some of the Nazi goals. ${ }^{1}$ It was through racial policies and the desire to foster these that a real willingness to jettison traditional practices showed itself. The formation of a welfare scheme such as the Muk, which promoted both increased fertility and a return to the values of the essentially nurturant function of women's activities, at the same time tried to raise expectations of the role of women as it related to the task of child-bearing. ${ }^{2}$ The Muk was intended to support the health and welfare of actual and future mothers, which became a matter for concern at the highest level, and it was for this reason that women of child-bearing age would find themselves enjoying, from officialdom at least, greater

1. Ian Kershaw, Popular Opinion and Political Dissent in the Third Reich, Bavaria, 1933-45. Oxford 1983, p.1. Kershaw points out that, 'Nazi social aims were extraordinarily ambitious. They amounted to no less than a revolution in attitudes and values, a transformation of subjective consciousness more than of objective realities'.

See also Martin Broszat, The Hitler State, p.18.

2. Scholtz-Klink, 'Müterschulung in Deutschland', p.140, as she pointed out:

'the training of women for motherhood is no longer a matter for a small group of interested women, but a political task of the state in order that a woman can become aware of her duties to the nation'. 
social esteem than hitherto. ${ }^{l}$ However, it must be stressed that this improvement was limited in scope, confined mainly, though not exclusively, within a period of a few short years when the regime was concerned to persuade women to quit the workforce. ${ }^{2}$ Nevertheless it is clear that an intention existed whereby 'every day housework' would be elevated to the level of a skilled occupation. ${ }^{3}$ However, the activities of women as they related to work within the home did undergo some radical alterations in perspective, on the part of the NSV and NSF leadership, (and Scholtz-Klink in particular) who were required to provide extensive training courses for women in those activities which had previously been learned in the home or, only marginally, within the school. ${ }^{4}$ Housewifery and child care would become a matter for two organisations of the Party who would provide a whole programme of mothercare and homecraft instruction, and it would fall to the NSF to organise the practical courses through its DFW section. The RMD course was a clear attempt to fuse the mundane and the practical with the 'higher' aims of the regime. This served to introduce a particular perspective into the course content which itself stressed the 'exhalted' aspect of the previously low-status occupations of housewifery and child-care. Whether women attending these courses were fully persuaded of the new emphasis is itself questionable, however, many were introduced to the racially oriented nationalist goals of the regime in the form of a training for motherhood, whose significance for the future of Germany was stressed ad nauseam .

1. Stephenson, Women in Nazi Society, pp.196-197.

2. Ibid., pp.99-100.

3. Stephenson, The Nazi Organisation of Women. p.163.

4. Scholtz-Klink, 'Mütterschulung', pp.140-142. 
These provisions existed both as a practical and as an ideological support for other economic measures such as the Marriage Loan Scheme, which allowed a tax-free loan on condition that a wife leave her job. This ruling was lifted in 1937 which had the effect of raising the number of loan-assisted marriages from $24 \%$ in 1935 to $42 \%$ in 1939. Generous repayment arrangements meant that the birth of a first baby would result in the cancellation of $25 \%$ of the loan plus a year's grace on the repayments. If a further three children were born to a couple, then that meant the cancellation of the entire sum. $^{1}$ The state also provided family allowances which were made available in addition to those already in existence. Only a very few non-governmental allowances schemes survived the inflation of the 1920s, most notable of these being the scheme of the pharmacists which allowed for payments to wives and children under a complicated system of payments for each dependent child. From 1936, in addition to the Einmalige Kinderbeihilfen, which was a grant of up to 100 marks for the purchase of household goods to those parents who applied (and who were of 'unobjectionable' character), family allowances were available, and these amounted to 10 marks per month for the fifth and each subsequent child under the age of sixteen. However, other means-tested allowances for the third and subsequent children were also available; if the family size increased to seven children, then a monthly grant of 80 marks would be received. ${ }^{2}$ The pro-natalist policies of the Nazi government allowed

1. Stephenson, Women in Nazi Society, pp.46-47.

2. Glass, Population Policies, p.296. These allowances were the 'laufende Kinderbeihilfen' (allowed for the fifth and subsequent children) and the 'erweiterte Kinderbeihilfen', or allowances for the third and subsequent children. 
that every possible measure to encourage couples to take on the burden of larger families would be explored. Not all of these would be of a material nature, though many, of course, would take this form. The Party itself offered an honorific incentive which carried the mark and the recognition of the Party's approval, this was given in the form of an Honour Cross. ${ }^{1}$ These crosses, to be worn much in the manner of a battle honour, were only awarded to mothers of more than three children, and in three classes of bronze, silver and gold. However, it was not the Muk which presented them, but the Ortsgruppenleiter of the NSDAP who distributed them on Mother's Day, in the local Party offices. ${ }^{2}$ It is clear that this measure was intended as a symbolic representation of the value which would be placed upon the birth of 'racially valuable' children, and to act as an encouragement to mothers to produce more children, an activity which was intended to be undertaken as much for the sake of the nation as for more private ends. Indeed, these distributions of medals for motherhood were only part of the general urging of the population towards the laying aside of individualistic aims which was contained in the propaganda material of the NSV. ${ }^{3}$

Clearly, the 'Mother and Child' section of the NSV was intended before the war to act as a buttress for the various measures of the government's pro-natalist policy, rather than as a fully independent major activity such as the Winter Aid scheme. The MuK distributed a

1. BA, NSD 30/3 NS-Volksdienst, January 1939, 'Das Ehrenkreuz der Deutschen Mutter', p.37.

2. Ibid., bronze crosses went to mothers of four and five children, silver was awarded for six and seven, and gold for eight and more. A careful character search was carried out with regard to each request to be included in the numbers of Honour Cross holders.

3. HA, 13/259, 'Artikeldienst', for a useful selection of articles/information/propaganda pieces on NSV welfare. 
constant barrage of propaganda which reminded women of the joys of motherhood, and the duty to provide healthy children for the sake of the future of Germany. The MuK did, however, make extensive arrangements for the provision of advice and help for women who would undertake to produce large families, so that there existed some justification for the torrent of requests, reminders and persuasion to procreate which characterised Muk pro-natalist propaganda. ${ }^{1}$ The new provisions for welfare for mothers and children claimed to have a (new) unity of purpose, they were intended to function throughout the nation efficiently and even 'generously', and they were directed towards every potential or actual mother who could be regarded as racially and socially 'worthy'. However, there remained at the basis of the new Nazi arrangements an overwhelmingly partial view of the nature of social welfare as such. ${ }^{2}$ This had the effect of underpinning the discriminatory policies of the NSV which, at all times, stressed the importance of 'self help' not charity. Indeed, NSV welfare, even if it was part of the arrangements for mothers and children, was never intended to be charitable in nature, nor was it; MuK facilities, as well as every other NSV measure, were supposed, ultimately, to 'strengthen' the ability of welfare recipients to help themselves, so that they would not need to turn to the Party's

1. BA, NSD/30/7, Ewiges Deutschland May 1937. This NSV publication contained articles and sentimental items with a strong pro-natalist slant. See 'Zum Muttertag', and 'Die Hunde einer Mutter', pp.3-4; Jill Stephenson, '"Reichsbund der Kinderreichen": the League of Large Families in the Population Policy of Nazi Germany', in European Studies Review, London, 1979, p.363. Stephenson points out that pro-natalist propaganda continued undiminished during the war.

2. Reher, Social Welfare, p.24. 
welfare provisions on a continuing basis. ${ }^{1}$

Family oriented welfare for Nazi sympathisers had begun in 1932 in Oldenburg at the time of the successful activities of the Party in that area, when the states' elections in Mecklenburg-Schwerin and Oldenburg brought the NSDAP to power, ${ }^{2}$ Party welfare, at this time in this area, consisted of the nucleus of a special nourishment programme for expectant and nursing mothers, and also the distribution of articles of clothing for infants and young children of SA men and other Nazi supporters. ${ }^{3}$ The much expanded and systematised arrangements of the MuK after 1934 retained much of the character of the Oldenburg facilities which had been organised only to help Nazi supporters and their families. But the inward-looking, 'self-help' emphasis of 1932 remained, to some extent, within the later arrangements for family welfare within the Muk. A determined effort to assist those supporters whose need was not of their own making (the unemployed, the badly housed), during the Depression years marked indelibly the later design of the MuK. Indeed the MuK from 1934, for all the rhetoric, was only a Party self-help facility writ large, with the constituency of the needy being enlarged from small groups of Party activists, to take in the wives and the families of the 'racially valuable' members of the entire group which made up the Nazi Volksgemeinschaft. During the formative period of Nazi welfare, one of the most useful ways of establishing an effective welfare measure was to make sure that families were given

1. Ibid., pp. 4; Erich Hilgenfeldt., Idee, p.10.

2. Orlow, The History of the Nazi Party: 1919-1933, p.254.

3. HA, 14/262, 'Familienhilfe wird geleistet', p.15. 
help and advice in making-do with meagre resources. ${ }^{1}$ Both the Muk, and the measures for the training of women to become efficient housekeepers and child carers through the DFW's Reichsmutterdienst, certainly retained the flavour of these earlier measures. Perhaps this was for the important reason that the Nazi imagination was fixed permanently, it seems, within the philosophical and ideological framework of the 'time of struggle'. The perception of social welfare by the NSV was profoundly influenced by the experiences and the difficulties of the period prior to the assumption of power, when 'self-help' became the dominant means by which Party activists could survive financially. The necessity of making full use of existing scarce resources before 1933, was a 'virtue' which later became enshrined within the welfare provisions of the NSV and its various sections, including the MuK.

In order to establish the Muk nationwide, an advisory committee was formed and included representatives from the Ministry of Interior, the Propaganda Ministry, the Deutscher Gemeindetag, the Office for the People's Health, the women's organisation and several other agencies. ${ }^{2}$ Under the presidency of Erich Hilgenfeldt, the leader of the NSV, the administrative committee met together on the 28th February 1934, for the first time, and it was on lst April 1934 that the Mutter und Kind section of the NSV came into being. The Reich Minister of the Interior publicly welcomed the new measure and said at the time:

'Such a welfare scheme which is now being established can
only be greeted most warmly because of its significance
for population policy in general; the state organs will
be expected to provide a good working relationship with
the NSV's whole Muk project'.

1. Ibid., 'Kinder werden gespeist', p.16.

2. BA, NS 37ii/1035, 'Bericht MuK', pp.1-4.

3. Ibid. 
These hopes, however, would only be realised where the Muk and the state provisions were not seeking to provide parallel facilities; where the Muk became involved in the setting up of kindergartens and other pre-school provisions, the state officials would monitor every new MuK or NSV attempt to increase its participation within this field. $^{1}$ This is not to say that the Nazi organisations themselves did not provide a measure of cooperation and help in the setting up of the new welfare section of the NSV. Agreements were made between the NSV and the NSF, the NSLB, the midwives' association and the Reichsjugendfuhrung (Reich Youth Leadership). Most importantly, the NSF/DFW had been charged with organising the mothercare courses which were intended to provide the basis of new training schemes for German women. ${ }^{2}$ The provision of training and education within the Reichsmutterdienst mothercare courses should be seen as an intrinisc part of the attempt to form an extensive, and perhaps comprehensive, welfare scheme for mothers and infants. Other aid which would be forthcoming included the Domestic Aid scheme of the NSV, and the holiday schemes for mothers run by the MuK. Mothers of families with more than two children would be given the opportunity of a free holiday for those who could not themselves pay, and a domestic help on a daily basis, where the arrival of a new baby was making extra work to an intolerable degree for the mother of the family. ${ }^{3}$ In other words, every inducement to increase family size was provided by the Party's welfare organisation, from economic help

1. $\mathrm{BA}, \mathrm{R} 36 / 962 ; 964$.

2. Scholtz-Klink, 'Mütterschulung', pp.137-149.

3. BA, NSD 30/4, NS-Volksdienst, September 1941, 'Die Haushalthilfe der NS-Volkswohlfahrt', p.180. $\mathrm{HA}, 13 / 259$, 'Informationsdienst', Nr. 18, 'Die Haushalthilfe der NSV'. 
(in the form of food supplements and donations of clothing for infants), to free holidays and increased welfare facilities in the form of clinics and advice centres which would be set up throughout Germany. ${ }^{l}$ To achieve a rise in the birth-rate, all of these measures would be required, it was recognised, and the MuK would set itself the urgent task of improving the infant mortality rates through the increased care of pregnant and nursing mothers. ${ }^{2}$ To some degree these goals were beginning to be realised by 1936, when the infant mortality rates showed a continuing tendency to fall, from $7.7 \%$ in 1933 , to $6.6 \%$ in $1936 .^{3}$ However, as suggested above, these figures had been falling steadily long before the advent of the Muk, so that it is difficult to assess how far the NSV's new welfare facilities can be held to have been instrumental in achieving lower figures. For example, these rates had already shown some improvement, going from 18.3 deaths in every hundred live births in $1905 / 9$, to 13.1 in 1920 , and 10.5 in $1925 .^{4}$

For the organisation of the various practical measures the Muk required the cooperation of the NSF at first, such cooperation was especially forthcoming as well as welcome where an NSF member was already acting as an adviser in the NSV Gau offices. ${ }^{5}$ But the MuK

1. BA, NS 22/457, 'Hilfswerk MuK 1937/8', p.23; NSD

30/51, Deine Arbeit, see 'Hilfstellen "Mutter und Kind"', clinics numbered 16,466 in 1935.

2. Ibid.

3. St.J., 1938, pp.66-67.

4. Ibid.; BA, NSD 30/4a, NS-Volksdienst, December 1943, 'Zehn Jahre Hilfswerk Mutter und Kind', P.167; HA, 13/259 'Informationsdienst I', 4406 (1940).

5. BA, NS 37ii/1035, 'Bericht MuK', see, 'Zusammenarbeit mit parteiamtlichen Organisationen'. 
would quickly establish its own corps of domestic helpers through the Women's Labour Service and through the recruitment of girls and young women who wished to become NSV social workers and kindergarten nurses. ${ }^{l}$ A shortage of personnel would remain as a continuing problem, however, and the MuK would find itself hard-pressed to provide enough domestic helpers in order to fulfil earlier promises to give a helper to every mother who needed one. ${ }^{2}$

From 1934, every Ortsgruppe made special facilities available where mothers with young children could receive general help and advice. Specialist medical advice was on hand if required, and it was possible to obtain useful hints on child care from the local Party office, for at specified times, mothers were able to consult a child-care specialist who was available for this purpose. These services would soon expand into the network of MuK infant care/advice centres (Hilfstellen/Beratungstellen), numbering 24,478 by 1937.3 The staff of the MuK clinics and advice centres stressed the importance of rational and modern methods of child-care, even though the published material of the NSV continued to show a romanticised view of motherhood in articles and photographs. ${ }^{4}$ The help and advice on offer in the Muk clinics, and in the Reichsmutterdienst courses,

1. BA, NSD 30/50, Schule fUr das Leben, ein Beruf in der NSV, Berlin n.d. (?1938) p5.

2. I am grateful to $\mathrm{Dr}$. Jill Stephenson for giving me information on this, SD reports in 1941 and 1943 outlined shortages in respect of household helpers (WUrttemberg 1941) and in infant care centres throughout Germany (1943).

3. BA, NS 22/457, 'Hilfswerk MuK 1937/8', p.23.

4. Ibid., p.5.; BA, NSD 30/7, Ewiges Deutschland, May 1937, see 'Die Kunst geh甘rt dem Volk: Hilfswerk fur Jeutsche bildende Kunst', and also, 'Briefe zum Muttertag', p.5. 
were based on good hygienic practices and the dissemination of these, plus a grounding in the efficient health care of the family in general and a basic knowledge of the dietary needs of children. ${ }^{\text {l }}$ Above all, young women were encouraged to abandon any reliance on traditional methods of child-rearing if these could be proved to be inefficient or ineffective as well as positively damaging. ${ }^{2}$ An examination of the numbers of women attending these clinics shows that they were reasonably popular, and many did make use of Muk facilities. Numbers of visits in 1936 amounted to 3,410,848 and rose to 3,573,486 in 1937. For a useful comparison, it can be seen that the total number of women of childbearing age (1937) amounted to $16,547,000$, and each clinic received approximately twelve visits per month before the war. ${ }^{3}$ The numbers of visits to Muk clinics from 1935 to 1941 can be seen as follows:

Numbers of visits to MuK clinics and advice centres 1935-1941

$\begin{array}{ccc}\text { Year } & \text { Numbers of Clinics/ } & \text { Total Visits } \\ & \frac{}{\text { Advice Centres }} & \\ 1935 & 25,552 & 3,358,075 \\ 1936 & 26,279 & 3,410,848 \\ 1937 & 24,478 & 3,573,486 \\ 1938 & 25,751 & 3,852,160 \\ 1939 & 32,577 & 4,601,511 \\ 1940 & 33,325 & 7,157,163 \\ 1941 & 28,936 & 10,311,121\end{array}$

1. HA, 13/259, 'Informationsdienst' II/If. See, Schulungsplan 'Die Mutterschaftshilfe', p.37; Scholtz-Klink, 'Mütterschulung', p.143; Frau Dr. Johanna Haarer, Die Deutsche Mutter und ihr erstes Kind, MUnchen/Berlin 1944, pp. 269-273.

2. $B A$, NS $22 / 746$, 'Arbeitsplan fur die lehrgănge der Heimleiterinnen von Muttererholungsheimen', January 1938.

3. BA, NSD 30/51, Deine Arbeit, numbers of clinics (Hilfstellen only) rose from 16,466 in 1935 to 29,818 in $1940 ;$ St.J. 1938 , p.47.

4. BA, NSD 30/51, Deine Arbeit, see tables given. 
Visits to clinics as can be seen from the above figures rose markedly during the war years, however, this matter will be dealt with in more detail below, in Chapter Seven.

During 1934 however, the clients who might use MuK facilities still had to be found, and there was a determined effort made to discover those who might usefully attend. ${ }^{l}$ With the active participation of the NSV Blockwalter who made the existence of the Muk known to every pregnant woman or mother of young children within his area, the NSV's aim was to ensure that, as far as possible, everyone who could benefit was made aware of the new welfare arrangements. ${ }^{2}$ But it certainly seems as though the 'reminding' of women to attend MuK clinics, a task of the NSV Blockwalter, was for the most part, successfully carried through, although officially at least, such reminders were meant to stop short of duress. On the other hand, the clinics themselves were capable of being seen as inherently useful to women where weighing and other useful facilities were on offer. Nevertheless, no particular mention is made of the Muk clinics in the confidential reports of the Gau Sachsen, apart from the reference to an expansion of the Reichsmutterdienst courses which were to receive in 1935 an extra RM $3,000 .{ }^{3}$ But it is fairly certain that the Muk holiday schemes were proving to be one of the most popular of all the NSV schemes at this time in Saxony. ${ }^{4}$ The Muk also obtained help from the professional midwives'

1. BA, NS 37ii/1035, 'Bericht MuK', 'Erfassung der Hilfsbedurftigen'.

2. Ibid.

3. BA, NS 37ii/1062, Gau Sachsen 'Tatigskeitsbericht der Wohlfahrtsabteilung Marz 1935', (331251).

4. Ibid. 
association in the attempt to locate many needy cases, for the midwives were required to pass on to the NSV information on all such cases which came to their notice. District welfare offices too passed on relevant information, and the files of the Winterhilfswerk were combed for suitable cases to be taken up by the Muk. ${ }^{l}$ In other words, all relevant sources of information about mothers and infants came under the scrutiny of the officials of the NSV/MuK. Given that the Public Registry Office was required to inform the NSV of all births which had taken place, the MuK was in a position to try to establish its influence over the guidance of new mothers who, in the normal run of things, were likely to be receptive to the infant-care advice on offer from the Muk clinics. ${ }^{2}$ But it was intended that such advice would be accompanied by pro-natalist propaganda, and racialist ideas about the 'strengthening' of the nation. While it is possible to say that the practical help which was made available proved itself to be welcome, in some cases at least a rise in the disposable income of the family would have been far more welcome than the hand-outs from the NSV or the MuK. ${ }^{3}$ More difficult to assess is, of course, the impact of MuK propaganda on mothers who passed through the MuK clinics and advice centres. Willingness to accept help with the problems of infant care did not, necessarily, signify an acceptance of some of the more extravagant ideas about the duty to produce more

1. BA, NS 37ii/1035, 'Bericht MuK', 'Erfassung der HilfsbedUrftigen'.

2. BA, NSD 30/2, NS-Volksdienst May/June 1938, 'Die Aufgaben der Hilfstelle Mutter und Kind', p.247; Erich Hilgenfeldt, Aufgaben der NS-Volkswohlfahrt, Berlin 1937; Reher, Social Welfare, pp.22-23.

3. BA, NS 37ii/1062; Kershaw, Popular Opinion, p.101. 
children for the sake of the Nazi Volksgemeinschaft. I While it is true that the German birth-rate showed an improvement from 1933, going from 14.7 per thousand of the population in that year, to 19.0 in 1936, it is by no means clear how far Nazi population policies can be held to have been responsible for such a rise. ${ }^{2}$ Not surprisingly, the NSV would continue to claim that such was the case. However, this point will be dealt with in more detail below.

The practical work of the MuK was put into an operational plan which remained virtually unchanged and consisted of six main elements:
1) Material assistance (economic assistance)
2) Workplace help (aid in finding employment)
3) Aid with housing needs
4) Aid for pregnant women
5) Aid for single mothers
6) Holidays for mothers
7) Other measures.

With regard to the first item, the NSV always intended that MuK material welfare would only be granted as an addition to that which was already being received from the state. ${ }^{4}$ Thus the Muk organised a

1. Stephenson, 'Reichsbund der Kinderreichen', p.369.

2. Glass, Population Policies, pp. 306-313; Stephenson, 'Reichsbund der Kinderreichen', p. 368-369.

3. BA, NS 37ii/1035, 'Bericht MuK', (IV) 'Wirtschaftliche FUrsorge'; HA, 13/259, 'Informationsdienst' II La/2149, Hilfstellen Mutter und Kind.

4. BA, NS 37ii/1035, 'Bericht MuK', 'Zusammenarbeit mit der Uffentlichen FUrsorge'; F. Wunderlich, Farm Labor in Germany, princeton 1961, 0.271. 
distribution, for needy families, of food parcels, food stamps, bed linen, bundles of baby clothes and, if families were especially needy, second-hand clothing and lengths of dress material. ${ }^{1}$ This list shows how MuK economic assistance was intended only as a fairly modest supplement to other welfare measures available from the state. In spite of the fact that the figures given by the NSV in 1935 were expressed in thousands and therefore look somewhat impressive, the amounts of goods distributed were usually quite modest. For example, in the Gau Munchen/Oberbayern in 1935, MuK disposed in a single month of 25,800 litres of milk; 1,500 food parcels, each worth two marks and containing coffee, sugar, flour, rice, semolina and rolled oats; parcels of clothing for a new baby, each worth ten marks and containing six vests, swaddling bands, nappies, cot-blankets, a rubber sheet, three infant jackets and one bath towel. Gau Weser-Ems also distributed in the same year (1934/35), during a one month period, 25,000 pieces of assorted bed linen and blankets worth 13,380 marks; $360 \mathrm{~kg}$. of knitting wool worth 3,900 marks; 5,160 kg. of quilt-making material and $31,000 \mathrm{~kg}$. of peat as a supplement to Winterhilfswerk coal. ${ }^{2}$ Every Gau was involved right from the start in providing through MuK the necessary items for a new infant, thus easing the burden for those who were unable to buy a minimum of baby clothing without a real struggle. ${ }^{3}$

The Muk holidays for mothers scheme seems to have been viewed as one of the most effective propaganda assets of the whole Muk

\footnotetext{
1. BA, NS 37ii/1035, 'Bericht MuK', (IV) 'Wirtschaftliche Fursorge'.

2. Ibid.

3. Ibid.
} 
programme. It was also viewed as being a popular and effective means of arousing interest in the NSV as a whole. In the attempt to gain more voluntary helpers for the NSV, it was decided during the course of one campaign to ask one of the mothers who had been sent on a free Muk holiday 'to say a few words' to the assembled audience. ${ }^{1}$ Not only this, but some new members joining the NSV in 1935 were said to have been encouraged mainly by the favourable impression which had been givenby the Muk holiday schemes. ${ }^{2}$ On the part of the Muk itself, the whole holiday programme was valued for its useful contribution in bringing back to health and strength those women who had been unable previously to afford an annual holiday. ${ }^{3}$ The provision of free (or nearly free) holidays was perhaps also one of the ways in which support from women for the MuK facilities as a whole could be drummed up without having to rely too heavily on propaganda material which was given in a written form and which was distributed in the clinics and advice centres. Inevitably, such material, whether it was in the form of pamphlets or of speeches given at an organised event, had less immediate impact on a busy mother who had little time to read, and had little interest in attending Party-organised events, or in joining the NSV or NSF/DFW. ${ }^{4}$ It certainly seems that the courses in mothercare, and the holidays of the Muk, carried a major responsibility for putting across the message of Nazi population policies, as far as they were being

1. BA, NS 37ii/1062, Gau Sachsen, 'Stimmungsbericht' Wohlfahrtsabteilung, May 1935.

2. Ibid.

3. Reher, Social Welfare, p.22-23.

4. Stephenson, The Nazi Organisation of Women, p.170. 
distributed through the welfare measures of the NSV. For those working-class women who were perhaps less accessible than most, the holiday scheme of the Muk gave an opportunity for a concentrated exposure to Nazi family and health care policies. Nevertheless, at the same time, there existed a genuine wish to offer a rest, in the form of a summer break, to every woman in need of one; farmers' wives were of course offered a winter or early spring vacation, as work on the land allowed. ${ }^{l}$ The aim to return mothers renewed and refreshed to the care of their children, no doubt also contained the expectation that further pregnancies would occur in due course. ${ }^{2}$ The categories of those who were eligible for free holidays were as follows:

a) mothers with more than two children;

b) those, who whether through illness or recent childbirth, were in need of a rest;

c) those who had participated during the Kampfzeit in work for the Party. (3)

As Werner Reher, a senior NSV official pointed out, holiday/recuperation homes were quickly put into service and for the period of May 1934 to April 1935, some 43,000 mothers obtained free

1. BA, NS 37ii/1062, Gau Sachsen 'THtigskeitsbericht MHrz, 1935'.

2. Reher, Social Welfare, pp.23-26.

3. BA, NS 37ii/1035, 'Bericht MuK', 'Muttererholungsfursorge u. Mutterschulung'. 
and partly self-financed holidays in MuK homes in the country. ${ }^{l}$ Such holidays afforded the participants, it was stressed, a well-earned rest, possibly 'for the first time ever'. ${ }^{2}$ During the period of a three week break, informal discussions took place between the holiday-makers and the Muk staff whose task it was skilfully to direct attention towards issues of a domestic nature, such as household and kitchen management and the exchange of recipes for cheap and nourishing meals. Such kitchen-orientated discussion provided an opportunity to impress on the mothers the importance of a healthy diet for their children, and they were given information about the preparation of nutritious but low-cost dishes for the whole family. Given that these subjects were the ones, apart from unsupervised gossip, which were discussed in the presence of the Muk helpers while basking in the sun, one must assume that every possible opportunity to educate and to train women to carry out their traditional tasks would be grasped. One NSV official was inspired to write of the Muk holiday thus;

'those weeks of rest and recuperation are also weeks in which the minds of the mothers are stimulated and furnished with new and brighter ideas'.

1. BA, NSD 30/51, Deine Arbeit, 'laufende Mutterverschickung'; BA, NS 26/261, 'AuIkommen und Verwendung', p.31.

Numbers of women obtaining holidays 1934-1941

1934

1935

1936

1937

1938

1939

1940

1941
40,350

65,676

69,876

77,169

77,723

63,139

55,289

62,856

2. Reher, Social Welfare, p.23.

3. Ibid., pp.23-24. 
While Muk welfare discriminated in favour of the 'eugenically valuable', it did not discriminate only in favour of women Party members, or those who had been frankly and openly in support of the Nazi cause. On the contrary, the NSV's leaders were keen to point out that former supporters of other parties, 'even those who had formerly been opposed to National Socialism', would receive an Muk holiday and be included within other NSV and MuK facilities just the same. ${ }^{l}$ Though Reher's statements were, in the main, part of the attempt to publicise abroad the new arrangements for welfare in Germany, the NSV was quite genuine about the offer to include all women in its arrangements if they fulfilled the conditions of the 'racially valuable', 'socially worthy', category. ${ }^{2}$

The cost to the NSV/MuK of the holiday scheme was relatively small, and represented in 1937, 12\% of the total spent on the Muk as a whole; that is, to send 77,169 mothers away on holiday during 1937 the sum required was RM $11,877,250 .{ }^{3}$ Costs to an individual Gau for the scheme can be seen to have amounted to RM 1,281 in one month in 1935 in Sachsen. ${ }^{4}$ This sum represented the travelling and other costs of mothers for a rest in Muk holiday homes. The first quarter of the year 1935, saw 1,093 women from Sachsen being sent away for a break, and they were suitably furnished with some money and knitting wool to take with them. The relative success of the Muk holidays by 1935 is shown in the rising demand for these in Sachsen where,

1. Ibid., Reher's book was written by him in English.

2. Ibid.; see instructions on this, BA, NSD 30/11, Informationsdienst, March 1939, Teil II/

'Wohlfahrtsflege u. Jugendhilfe', pp.99-101.

3. BA, NS 22/457, 'Hilfswerk MuK 1937/8', p.28.

4. BA, NS 37ii/1062, Gau Sachsen 'Tutigkeitsbericht der Wohlfahrtsabteilung Marz 1935' (331251). 
given an increased number of requests for places, many more suitable recreational homes were reported to be required. These would have to be found and made ready as soon as possible. ${ }^{l}$ The costs of a stay in an MuK Home were not met only by the NSV/MuK, for grants from the state, the local communities, or health insurance, would all be sought before Muk funds were called upon. ${ }^{2}$ However, Muk was happy to provide suitable clothing for those requiring light-weight summer wear for their holiday without charge, which they were allowed to keep. 3

Inevitably, the absence of a mother from the family, when she was on an Muk break, meant that someone had to stand in for her, so that the household could continue to run smoothly. One of the functions of the NSV Haushalthilfe scheme (Domestic Aid), was to provide such help. ${ }^{4}$ However, the main function of this particular NSV welfare scheme was to provide a daily help, for up to eight weeks (or longer in certain special cases), in the home of a newly delivered mother if there were very small children in the family already. ${ }^{5}$ The promise of such practical help was intended to add a realistic and an attractive inducement to the numerous appeals to increase family size which, over the years, would take on an increasingly strident note. ${ }^{6}$ The duties of the NSV domestic helper

\section{Ibid.}

2. BA, NS 37ii/1035, 'Bericht MuK', 'Muttererholungsfursorge u. Mutterschulung'.

3. Ibid.

4. HA, 13/259 'Informationsdienst' $\mathrm{Nr}$. 18, 'Die Haushalthilfe der NSV'. BA, NSD 30/4, NS-Volksdienst September 1941, p.178.

5. Ibid.

6. NSD 30/7/8, Ewiges Deutschland, May 1937; September 1938. 
were exactly those of the normal workload of the mother to whose family she (the helper) had been assigned. An eight-hour working day was meant to be extended, if needed, so that every important task was completed before the end of the day; indeed, the domestic helper was supposed to 'remain at her post until the last job was finished'. ' An NSV daily help would be assigned only when certain specific situations arose within a family's circumstances. These were described to be as follows:

1) during the period before and after delivery for mothers with more than one or two children;

2) during the mother's absence in a recreational Home or when a mother was undergoing a spell in a clinic or having treatment in a hospital;

3) general help for 'kinderreich' families and motherless households;

4) aid for families where the mother was in need of extra help through illness.

Such a list suggests that the NSV might experience some difficulty with regard to finding enough helpers to carry out an extensive programme of aid for new mothers and those who were unable to look after their children through ill-health, as well as acting as a support scheme for mothers who were away from the family home on an Muk holiday for a few weeks. This ambitious set of aims ran into difficulties as events were to show. The two categories which would

1. BA, NSD 30/4, NS-Volksdienst, September 1941, p.180.

2. Ibid., p.181. 
later experience the most difficulty in obtaining a household help were the two which needed such help most, that is to say, mothers of several children and farmers' wives. ${ }^{1}$ In the Gau Westfalen-Nord in the country area of LUbbecke in 1937, the entire holiday scheme of the MuK came to grief through the impossibility of finding a temporary replacement for the poorer mothers of the area whose neighbours, or relatives, were unable (rather than unwilling) to give any help by acting as a stand-in for an absent mother. At this time the NSV in this area seems to have been unable to provide sufficient personnel for this task. ${ }^{2}$ The NSV looked to the women's Labour Service to provide numbers of suitable helpers for the Haushalthilfe scheme, and it seems that girl students, who were required to work for six months in domestic service or in agricultural work from March 1934 (in order to be eligible for first matriculation), were one of the sources for the NSV's domestic help and other services. 3 In 1937, 0.6\% of girl students doing their Labour Service were working for the NSV as domestic helpers, and $5.7 \%$ as kindergarten helpers. The majority, $80.1 \%$ were employed as cheap labour on the land while the rest, $13.6 \%$ were working in towns and cities. ${ }^{4}$ With

1. Ibid. P.180;

I am grateful to Dr. Jill Stephenson for confirming this impression in relation to research being undertaken with regard to werttemberg in war-time.

2. RUdenhausen, 'NSV/Westfalen Nord', p.239.

3. Jill Stephenson, 'Women's Labor Service in Nazi Germany', Central European History, 1982, p.246; Reher, Social Welfare in Germany, Reher suggests misleadingly that girl students 'volunteered' in all cases, p.22; for an examination of this topic see Durte Winkler, Frauenarbeit im 'Dritten Reich', Hamburg 1977, pp.129-133.

4. Wunderlich, 'Farm Labor', pp.318-319. 
regard to its own personnel, the NSV required that a period of work in a family household was an essential prerequisite for entering a training course for NSV Volkspflegehelferinnen (nursery nurses). Those who wished to be taken into the training courses for kindergarten nurses, or welfare work in general, were advised to opt for a stint as an NSV household help before they started a training course. $^{l}$ This was the kind of measure which the NSV favoured, in that one feature of the NSV welfare programme supported another but without necessarily costing any more money. In the above example, young girls were given an initial training for work in children's Homes and nurseries while, at the same time, they provided stand-in duties for absent mothers of families or acted as a daily help for newly delivered mothers. ${ }^{2}$

By 1938, a monthly average of 6,000 young women were involved in the NSV's domestic help scheme and the numbers of families who obtained such help were as follows:

\section{Monthly average of families with a NSV domestic helper}

$\begin{array}{ll}1938 & 10,471 \\ 1939 & 15,192 \\ 1940 & 20,802 \\ 1941 & 25,498\end{array}$

The numbers of available domestic helpers were significantly raised from 1938 by the contribution of young women who were involved in the

1. BA, NSD 30/50, 'Schule fur das Leben', pp.2-13.

2. Ibid.

3. BA, NSD 30/4, NS-Volksdienst, September 1941, p.186. 
compulsory year's service in the Pflichtjahr. All Pflichtjahr girls were meant to be employed either in domestic service or in agriculture. From the period of February to July 1938, 30,400 girls were undertaking this service in the agricultural sector, and 47,000 were busy in domestic service both in town and country. ${ }^{l}$ In 1939 , as many as 217,000 Pflichtjahrmaddel were similarly occupied within the same time span. Even during the first year of the scheme, however, it was clear that not all of the girls were being employed in families with several children, or with farmers' families. Many of these girls were managing to obtain a position in childless households in towns and cities. ${ }^{2}$ This particular practice was still in operation during the war, for in 1941, the NSV drew attention to the serious inefficiencies which had been allowed to take place with regard to the assignment of girls who were undertaking domestic service which was not being organised by the NSV. The 'shocking example' of one Ortsgruppe of the Gau K8ln/Aachen had revealed that many of the Pflichtjahr/Labour Service girls were being placed within households with no children. ${ }^{3}$ of the 224 girls undertaking domestic service in the unnamed Ortsgruppe, as many as 86 had managed to obtain a place in a childless household and of the rest, 52 were working with a family which had only one child, while 48 were working with families with two children. The remainder, only 38 in all, had been assigned to families with three children or more. It is unclear from this report whether there were very many families with several children in the same area who were going without a domestic help

1. Winkler, Frauenarbeit, p.58.

2. Ibid.

3. BA, NSD 30/4, NS-Volksdienst, September 1941, p.180. 
altogether because most girls were at pains to avoid a placement with the larger families in KOln/Aachen. However, in this report the NSV wished mainly to emphasise that many of the domestic helpers, who were being organised through the Pflichtjahr/Labour Service were shirking work which they were intended to undertake. Not only this, but the NSV and the MuK both expressed dissatisfaction with the conspicuous lack in the Pflichtjahr girls of a 'correct point of view', unlike those in the NSV Haushalthilfe scheme in the past, so that a shortage of suitable war-time help had contributed to a 'lowering of standards' in terms of ideological acceptability. ${ }^{l}$ This feature was one which the NSV was at pains to discover when taking on new personnel, but especially regarding those to be employed as kindergarten nurses. The NSV head office in Berlin circulated all local NSV offices with a list of those who had shown themselves to be unsuitable while undertaking training, to make sure that none slipped through the net. ${ }^{2}$

By the autumn of 1941 , it was clear that a serious shortage of domestic help, both from the NSV or the Women's Labour Service, was causing many to go without promised help. A serious shortage of such help in Wurttemberg during 1941 meant that the most hard-pressed mothers were having to wait for 'weeks and weeks' according to one SD report, for help with newly born infants. ${ }^{3}$ It was to be wondered, added the report, where the idealism of the young women had gone, since they were clearly unwilling to help their sisters who were in

1. Ibid. This applied also to kindergarten staff, see Chapter Six.

2. BA, NS 37ii/1030, to all NSV Gauamtsleiter, Amt fUr, Volkswohlfahrt, 'Meldungen fur die Warnkartei', 23rd November 1937.

3. I am grateful to Dr. Jill Stephenson for confirming this. 
some need. ${ }^{l}$ As though in response to this situation it was announced at the same time, during the Autumn of 1941, that the NSV intended to expand the numbers of its own domestic helper corps and that a new category, namely all unsupported mothers, would receive help for two weeks before, and four weeks after, a delivery. ${ }^{2}$ For the time being, shorter periods of help would only be available until 'new arrangements', as the NSV said, were put into force, ${ }^{3}$ in other words, until more helpers could be recruited. But the NSV were hopeful of an increase in the numbers of these, for with the extension of the period of compulsory service for girls in the RADwJ (Reichsarbeitsdienst der weiblichen Jugend), from six months to twelve months in July 1941, it seemed clear that the NSV would obtain an increase in the numbers of its helpers from this source. ${ }^{4}$ From the summer of 1942, the NSV was able to take girls in the age group 16 to 18, now included in the Kriegshilfsdienst, into domestic service for families with several children (kinderreichen Familien). ${ }^{5}$ It may also have been that the NSV hoped to keep a closer watch upon those girls who were assigned to domestic service so that they would be unable to avoid a placement with larger families.

Requests to be allowed an exemption from Labour Service were allowed however in those cases where a girl was already working in a munitions factory, or if there were several younger brothers and

1. Ibid.

2. BA, NSD 30/4 NS-Volksdienst, September 1941, p.181.

3. Ibid.

4. BA, NSD 30/4a NS-Volksdienst, December 1943, 'Zehn Jahre Hilfswerk Mutter und Kind', p.169.

5. Ibid. 
sisters at home. Indeed, at least until 1940, there existed a fair degree of leniency in this respect. ${ }^{l}$ There seems little doubt too that compulsory service, when not actually avoided, was made less onerous for some. As people at the time were quite aware, those most likely to achieve this were the daughters of 'so-called better families'. 2 For those girls who had managed to obtain a placement with families within the parents' immediate circle, domestic service was rendered as painless as possible. It was also shown that Pflichtjahr was being avoided altogether in some cases, at least in 1938 when the Pflichtjahr scheme came into operation. ${ }^{3}$ A definite lack of a conscious sense of service for others, which the NSV wished to inject into its welfare provisions - and thereby help to engender within the population at large - can be seen to have existed among those girls undertaking compulsory service. Far from taking up such work with the appropriate sense of Opferbereitschaft, Pflichtjahr girls managed to escape domestic and other work with farmers' families by opting for more congenial duties in the Labour Service, with the aid of the existing loophole of being exempt from Pflichtjahr if engaged in Labour Service. ${ }^{4}$ It was also possible to shorten the total length of service by switching from one category to another (from Pflichtjahr to Labour Service), and, incidentally, leaving in the lurch those farmers' wives who had been assigned a Pflichtjahr girl. The NSV were not unaware of the difficulties of

1. Stephenson, 'Women's Labor Service', p.260; Winkler, Frauenarbeit, p.58.

2. Ibid., pp.58-59.

3. Stephenson, 'Women's Labor Service', p.253; Winkler, Frauenarbeit, p.58.

4. Stephenson, 'Women's Labor Service', p.253-258. 
fulfilling promises made to provide help to those in most need of it. But these promises, first given in 1934, were contained within the Muk range of objectives which had been originally part of the drive to increase the birth-rate, not an intention to supply domestic servants for those who could, even if it were with some difficulty, manage without one. ${ }^{l}$ The NSV household help scheme was intended to help only those whose need was inordinate, either through the addition of a new baby to an already sizeable family, or through illness, where very young children would be without the mother's care for weeks on end. ${ }^{2}$ It was for these reasons that the NSV officials were so incensed in 1941 by the knowledge that the organisers of the Women's Labour Service allowed a domestic help to many families who, according to the aims of the Muk, had no right to one. ${ }^{3}$ There is no reason to doubt the sincerity of NSV pronouncements on this matter, or that the NSV, certainly from 1939, would attempt to pursue rigorously the deployment of girls within the Haushalthilfe scheme.

From the start of the war there existed the intention to increase the provisions of the Haushalthilfe scheme in relation to a better provision for the hard working Landfrau. The Reichsnahrstand was involved in new agreements with the NSV and with Conti's approval it was intended that domestic helpers should spend as long a period with farmers' families as possible. A sum of 4,800,000 marks

1. $\mathrm{HA}, 13 / 259$, 'Informationsdienst $\mathrm{Nr}$. 18', 'Die Haushalthilfe der NSV'.

2. Ibid.

3. BA, NSD $30 / 4$ NS-Volksdienst, September 1941, p.180. 
was set aside in 1939/40 for these new provisions and the NSF was expected to provide expanded training courses for intending domestic helpers. ' Apart from the supply of helpers from the Women's Labour Service who were directed to the NSV on a regular basis, students undertaking agricultural science courses, and some teacher training courses, would be required to do a spell as a domestic helper as part of the practical part of their courses. It certainly seems that the NSF and the NSV from 1939 cooperated in this venture and the womens' organisation became more closely involved in the domestic helper scheme during the war. ${ }^{2}$

1. BA, R18/3781, Hilgenfeldt to Conti, 'Hauspflege und Haushalthilfe', letter of 15th November 1939.

2. BA, NS37ii/1031, 'Mother and Child' to all Leiter NSV, 'Erweiterung der Haushalthilfe zur Mutterschaftshilfe', Sth July 1940. 
The funds for Muk came initially from collections from the public so that the end of the winter $1933 / 34$ did not signal a respite from the ever-present collecting box into which the donations from the public were gathered. Notwithstanding the generous funding of the first official Winter Aid by the population, they would be asked again to dig deeply into their pockets to provide the finances for another Nazi welfare scheme. Surprisingly, perhaps, these collections undertaken in the spring and summer of 1934 raised substantial amounts for the new MuK and reflected perhaps the beginning of a return to work for many. ${ }^{l}$ The first collections took place on the 29th and the 30th March 1934, managing to raise RM $1,680,764$ between them. Other collections followed in rapid succession and took place in May, July and September. The NSV, together with the DFW, collected RM 1,410,000 on 2nd July, the fragrantly entitled 'Day of the German Rose'.' A comparison with the collections for Winter Aid shows that the MuK could match the sums collected during the winter months. ${ }^{3}$ Altogether, six Reich street collections in 1934 for MuK yielded RM 9,798,577; this figure compares favourably with six (Reich) street collections for WHW in 1934/35 which together raised RM 8,471,482. From the end of the summer of 1934, however, public collections undertaken on behalf of MuK would all but cease, so that the NSV's new scheme would have to be funded from another source, and it would be the WHW which would

1. BA, NS 37ii/1035, 'Bericht MuK', (ㅁ) 'Finanzierung des Hilfswerkes'.

2. Ibid.

3. BA, R43/564, 'Rechenschaftsbericht WHW 1934/35', p.14 
undertake to provide increasing sums yearly to support Muk measures. ${ }^{1}$ An awareness of the danger of exhausting the good-will and patience of the population through incessant collecting, caused the leadership to impose a ban on indiscriminate street collections being carried out by the Nazi organisations. It was recognised fairly quickly that public collections had developed into what can only be described as indiscriminate importuning by the members of such organisations. ${ }^{2}$ During the winter months of $1933 / 34$, due to the WHW collections, and on into the spring and early summer too, it had virtually become impossible peacefully to walk the streets of Berlin, and elsewhere, without meeting requests to contribute to one or other of the various Nazi money raising endeavours, and a ban was imposed on these activities in July $1934 .^{3}$ The decision to provide a major part of the costs of the MuK from other sources was influenced not only by this ban, but also by the possible realisation that it would be very difficult to find another, equally successful, formula as the one which had been discovered for the Winter Aid drives. Through the measures of the Propaganda Ministry, the WHW had laid claim to a rich variety of collection procedures, money-raising campaigns and publicity schemes, all of which would have been virtually impossible to sustain in a really effective manner later in the summer months. It was for this reason, perhaps, that the Muk would cease to undertake public collections, even though the summer collections of 1934 showed themselves to be quite successful in the amounts raised.

1. BA, NS 26/261, 'Zuwendungen an Hilfswerk Mutter und Kind', 'Aufkommen und Verwendung', p.2l.

2. BA, NS37ii/1035, 'Bericht MuK', (ㅁ) 'Finanzierung'.

3. Ibid. 
The NSV seems to have been sensitive to the problems and inherent dangers involved in depending too greatly upon endless street and house-to-house collections. At the end of the summer they were pleased to record that, in spite of the 'overburdening of the population through incessant collecting', unsolicited sums of money had been sent in to the NSV offices in Berlin for the MuK, a welcome sign, so they said, that support was forthcoming. One might also suppose that the summer collections in 1934 were a way of 'testing the water' with regard to a second NSV welfare scheme, and when the signs looked to be not unfavourable, it was decided that the WHW could be allowed to provide finance in order that the winter collections would remain the prime propaganda measure of collections through donation from the public. ${ }^{1}$

In 1935/36, the MuK obtained a substantial sum from the funds of the WHW. This amounted to RM 7,302,000 and it represented approximately between one tenth and one twelfth of Muk expenses for that year. ${ }^{2}$ It is impossible to be completely precise about this particular figure for no record of Muk expenses for the year 1935/36 has been found. However, Der Angriff included in 1937 a short report on the achievements of MuK in 1936 which suggests that the WHW subvention was about one tenth of all expenses at this time. ${ }^{3}$ From

1. Ibid., 'Diese Kleine Sachspenden...sind ein Beweis dafur wie stark der Gedanke des Hilfswerkes und die Verantwortung fur sein Gelingen im deutschen Volke lebendig ist'.

2. BA, NS 26/261, 'Aufkommen und Verwendung', 'Zuwendungen an Hilfserk Mutter und Kind', p.20.

3. Der Angriff 1937, p.9, MuK costs seem to have been RM 81,700,000 for the year 1936; BA, NSD 30/51, Deine Arbeit. See 'Leistungen des Winterhilfswerkes' and bar chart. 
this point on, however, the sums received by MuK rose year by year so that, increasingly, WHW income was transferred to welfare for mothers and children instead of providing increased supplies of the usual WHW welfare in kind. There seems to have been no shortage of WHW aid, and it looks as though there was more than enough to go round in terms of funds collected to finance NSV welfare measures. Given the semi-compulsory nature of some at least of the collection procedures of the WHW, there seems to have been no concern on the part of NSV officials that an unwelcome burden would be placed upon WHW funds. ${ }^{1}$ WHW subventions to MuK were as follows:

WHW Subventions to Muk from 1935/36 to $1941 / 42$

$\begin{array}{lr}1935 / 36 & 7,302,000 \\ 1936 / 37 & 79,097,000 \\ 1937 / 38 & 113,692,000 \\ 1938 / 39 & 261,772,000 \\ 1939 / 40 & 407,644,000 \\ 1940 / 41 & 597,680,000 \\ 1941 / 42 & 783,220,000\end{array}$

Of the various NSV welfare measures, only the MuK received substantial sums of money from the WHW funds, so that it was unique in this respect even though some small sums were given by the WHW to a few other NSV welfare measures such as the adult holiday schemes and health schemes also organised through the NSV. ${ }^{3}$ While the sums

1. Efforts by Party officials saw to it that amounts remained high, see Chapter Seven.

2. BA, NS 26/261, 'Aufkommen und Verwendung', p.20; NSD 30/51, Deine Arbeit, 'Leistungen WHW'.

3. BA, NS 26/261, 'Aufkommen und Verwendung', p.21. 
received by the MuK from WHW funds appeared in the Statistisches Jahrbuch fUr das Deutsche Reich, and in the official reports of the NSV, no particular mention was made in the v8lkischer Beobachter of the fact that money collected on the streets of the Reich for one welfare scheme was being earmarked for another. ${ }^{l}$ Thus the propaganda material of the WHW, which emphasised ad nauseam the necessity to contribute in order to combat the scourge of hunger and cold, neglected to point out that, strictly speaking, the purpose of sums collected was to finance, in part, the summer holiday schemes as well as the other measures, run by the Muk. This untruth, which was hardly the worst one which the Nazis saw fit to perpetrate, seems to have been of a particularly cynical variety, given that some of the population at least were pleased to donate to the WHW on the basis of stopping others from suffering from winter-induced misery. ${ }^{2}$ However, the decision to refrain from widening the frame of reference of the WHW collection procedures was no doubt made in order that no perceptual complications might arise and only serve to take away from the simple message of donating for winter measures to alleviate the poverty of the members of the Volksgemeinschaft. An admission that a much wider range of welfare facilities was actually being funded could only underline that which many must have realised, namely, that the population was being illicitly taxed without an admission of this by the government.

By 1937, the MuK was receiving as much as 50\% of its total costs from WHW funds, a sum which represented just under one sixth

1. Virtually nothing was mentioned either in the v8lkischer Beobachter or in the NS-Volksdienst articles on Winter Aid.

2. See Chapter Three. 
of all WHW income for that year. The remaining 50\% of Muk costs were supplied by state subsidies and, where possible, insurance funds, the NSV itself making up the short-fall. ${ }^{1}$ By 1940/41, however, the WHW subvention had risen from one sixth to just over one half of all WHW income for this particular year so that the amount of the subsidy at this time was RM 597,680,000. In 1940/41, the entire income for WHW amounted to RM 916,240,000. The subventions from WHW to MuK and to other welfare measures at this time were as follows:

WHW subventions to Muk and other measures 1940/41

Mutter und Kind

Volksgesundheitsdienst/

Hitler Freiplatzspende

Reichsmutterdienst

\section{Sommerarbeit/}

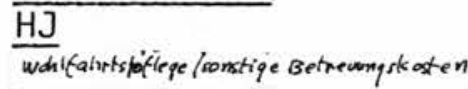

$552,200,000 \mathrm{RM}$

20,000,000 RM

$19,120,000 \mathrm{RM}$

2,500,000 RM (2)

3, $610,000 \mathrm{RM}$

From 1941/42 as much as two-thirds of all WHW income would be directed to MuK and it can be argued therefore that the size and importance of the WHW drives (not diminished during the war), and the tireless efforts to raise larger and larger sums of money only makes sense in the light of the explanation that such funds collected, from 1937, were called upon to finance not one but two NSV welfare measures. $^{3}$ Apart from the propaganda function of the WHW which remained as a prime motivating factor in the design of the drives, a less ideologically motivated goal also under wrote the efforts made to collect huge sums of money from the population, who wereing

1. BA, NS 22/457, 'Hilfswerk MuK 1937/38', pp.26-28.

The total cost of MuK welfare for 1937 was RM 99,298,457.

2. BA, NS 26/261, 'Aufkommen, Verwendung', p.21.

3. Ibid., p.20. 
called upon to finance a substantial amount of practical welfare activity on behalf of the Party. The population from 1933 was urged and cajoled into donating to welfare schemes which, as far as Muk was concerned, as well as the other NSV schemes, did benefit many, though on a far more modest scale than the Nazis claimed, and in some cases, at least, remained less welcome than a rise in income or, lower taxation, would have been.

The value of the various measures of MuK in 1937 was RM 99,298,457. This figure is represented as the costs to the Muk of its various measures. The largest proportion of this sum went not to the running of the clinics and the advice centres for mothers and infants, but to the holidays for children scheme (Kinderlandverschickung) which was organised within the administrative framework of MuK. ${ }^{l}$ The running of kindergartens and the care of very small children also came within the scope of the Muk under the section Kleinkinderfursorge (department 3 ) of the office Mutter und Kind, which was itself within section (C) of the department for general welfare within the NSV's administrative structure. ${ }^{2}$ In 1937, the value of economic aid through Muk for families in need came to $20 \%$ of the total of MuK funds for that year. As far as can be discovered, such financial assistance remained for the most part in the form of welfare in kind until the end of the war. As the head of the section Familienhilfe (MuK) pointed out in 1942, there was no

1. BA, NS 22/457, 'Hilfswerk MuK 1937/38', p.28; See Chapter Six.

2. BA, NS 37ii/1001, Reichsleitung Hauptampt fUr, Volkswohlfahrt; 'Hausrundschreiben Nr. 113/35', 29th June 1935 . 
place for a reine Wirtschaftsfursorge within Muk aid for families. ${ }^{1}$ Economic aid would remain in the form of advice on how to manage one's resources and a distribution of dietary supplements and clothing for small children as before. Part of the rationale of such aid before the war was, it is clear, the intention to save money and restrict welfare from the Party to a form which would also prevent dependent attitudes from forming. This type of aid would ensure that help would be distributed until economic circumstances improved but without encouraging a sense of welfare dependency on the part of those receiving NSV welfare assistance. ${ }^{2}$ It certainly seems that poorer families were pleased enough to receive such aid when given, as the example of the Gau Sachsen shows, but there seems little doubt that the sense of gratitude was far less than the NSV hoped and most seemed to view such aid as a hand-out, rather than the more elevated 'donation from the community', which the NSV and the WHW usually tried to claim characterised their welfare in contrast with that of the previous Weimar period. ${ }^{3}$ But it seems that this quality was exactly the one which was discerned by the poorer families in Sachsen. It seems in Bavaria too, that during 1937, workers who were on short-time (as in Sachsen during 1935), viewed WHW help merely as charity and not as a gracious donation from the Party which lifted away the hardship of their lives both in a symbolic and in a practical manner through the knowledge that the spirit of the

1. BA, NSD 30/75, NSV. Propagandadienst, 25th November 1944. Those in urgent need would be allowed monetary aid according to the Hitler Order of 1944 , see NSV tasks, BA, R36/963, 'Verfugung 11/44', 22nd August 1944.

2. Hilgenfeldt, Idee, p.5.

3. Ibid. 
Volksgemeinschaft expressed itself through welfare aid. ${ }^{l}$ From this point of view, the NSV and the WHW both had failed to persuade people of the 'true function' of Party welfare. Muk aid too, was received in just such a way in Westfalen-Nord, where concern over lack of money and a low standard of living was not alleviated by the needy being given a few food parcels and other welfare in kind from Muk in 1937.2

The exact value of such MuK aid is difficult to assess in respect of individual families, for the figures shown only set out a monthly average in relation to the numbers of children existing within each family. It certainly seems as though the amount of Muk welfare was worth as little as RM 20 per family per annum, though larger families would receive more than this. ${ }^{3}$ However, donations for the needy of items of welfare for infants and children in the form of dietary supplements, linen, beds and blankets, makes it difficult to say more precisely what the value of such aid was to those receiving help in kind. Muk does seem to have made improvements for the neediest of families in their sleeping arrangements through its Bettenfursorge whereby children would be ensured separate sleeping facilities in the family home through the donation of a new bed and bedding. ${ }^{4}$ Interestingly enough, relatively little was written about the specific economic aid which came from

1. BA, NS 37ii/1062, see reports of March to May 1935

from Gau Sachsen; Ian Kershaw, Popular Opinion, pp.84-86.

2. RUdenhausen, NSV/WestFalen-Nord, pp.239-241.

3. BA, NS 22/457, 'Hilfswerk $1937 / 38$ ', pp. 23-25.

4. Leistungen der NS-Wohl fahrtspflege, p.10. 
Muk; often enough it only merited a few lines where other Muk measures were given much greater emphasis, most notably the holidays for mothers scheme. ${ }^{1}$ This, to some extent, reflected the balance of the design of Muk measures in general, which stressed far more the provisions for the care and welfare for mothers rather than specific aid for the needy, unless it were in the form of dietary supplements for children as well as pregnant and nursing mothers. ${ }^{2}$ In the main however, it was the welfare measures of the WHW which would undertake to supply most of the welfare in kind which came from the NSV. ${ }^{3}$

By 1937, the MuK was well established with a total number of visits to clinics and advice centres amounting to 3,573,486 for that year. The number of clinics and advice centres at this time amounted to 24,478 . While newspaper articles gave an impression of the overwhelming success of this venture by quoting the total number of recorded visits up to, and including, 1942, that is, 36.3 million visits in all, it seems reasonable to say that the clinics of the Muk were showing themselves to be reasonably popular, and visits annually to these were being recorded in millions rather than thousands. ${ }^{4}$ An examination of numbers of visits per month, however, shows a less impressive figure. During 1937, the total number of visits per month was reported to be approximately from just under 200,000 to just over $300,000 .^{5}$ This is to say that throughout the country, each clinic

1. BA, NSD 30/4a NS-Volksdienst, December 1943, 'Zehn Jahre Mutter und Kind', p. 168.

2. BA, NS 37ii/1035, 'Bericht MuK'.

3. See Chapter Three.

4. BA, NS 26/261, 'Aufkommen und Verwendung', p.26.

5. BA, NS 22/457, 'Hilfswerk MuK 1937/78', p.27. 
was receiving approximately twelve visits per month. Altogether, 219,187 married women during 1937, were said to be receiving some form of Muk care before the birth of a new baby, with 21,701 single women receiving similar help. ${ }^{l}$ Such ante-natal care from Muk usually consisted of advice about a healthy diet and a distribution of vitamin supplements if required, plus reminders to attend the Reichsmutterdienst courses of the DFW when that was deemed to be appropriate. According to the photographs published by the NSV, such clinics were well furnished with suitable equipment and, it would seem, showed a welcoming atmosphere where mothers, who were accompanied more often than not by toddlers, could also receive advice on the care of their small children as well as ante-natal care as such. 2

1. Ibid., p.23; BA, NSD 30/36, 'Aufkommen und Verwendung', p.20.

2. BA, NSD 30/51, Deine Arbeit, 'Aus Einrichtungen der NSV'. 
Nazi population policies: success or failure?

A contemporary British assessment of the measures being undertaken in Germany to improve the birth-rate began with the statement that:

\begin{abstract}
'one of the most striking phenomena of recent years is the change in the trend of marriage and birth-rates in Germany since 1933. The change has attracted widespread attention only because Germany is the sole country in which, so far, population policies appear to have had any appreciable results, but also because the rapidity with which these results followed the coming to power of the National Socialist regime'.
\end{abstract}

This study also emphasised how difficult it was to account for the reason (or reasons) for the rise in the German birth-rate from 1933, but it was certainly as likely to have been as Glass pointed out due to factors other than the implementation of Nazi population policies. ${ }^{2}$ The problem of discovering how far these policies played a significant part in 'causing' the improvement in the birth-rate arises, the fact that one may have to cite changes in psychological perceptions and in social attitudes when explaining changes, and improvements, in the figures of the post-1933 German birth-rate. The Nazis themselves were not slow to point to these two potentially unmeasurable factors as forming the basis of improvements in the movement of the figures from $1933 .^{3}$ But the 'cause' of a rise in the birth-rate has to be discovered not so much in a single set of contributory factors, most of which rest within a socio-psychological frame of reference, but in a multiple and varied set of influences

1. Glass, Population Policies, p.269.

2. Ibid.

3. Ibid., P.306; HA, 13/259, 'Artikeldienst III/3041 Hauptstelle Presse, Hauptamt fur Volkswohlfahrt', 'Der Sieg des Lebenswillens'. 
which consisted of economic and other factors. For whatever reason the German birth-rate began to improve from 1933 and continued to do so until the outbreak of war in $1939 .^{1}$ The figure of 14.7 live births per thousand of the population in 1933 rose markedly to 18.0 in $1934,18.9$ in $1935,19.0$ in 1936 and 20.0 in $1939 .{ }^{2}$ Not only this, but the illegitimate birth-rate was showing a tendency to drop, reaching its lowest point in 1935, at 7.8 (illegitimate) live births per hundred babies born in that year. ${ }^{3}$ It seems necessary to conclude, therefore, that for whatever reason, married couples from 1933 were contributing to the rise in the German birth-rate. However, this important development was due more to an increase in marriages contracted from 1933 rather than an increase in fertility within marriage itself. ${ }^{4}$ The year 1932 represented the lowest level recorded of marriages contracted, namely 516,793 and this figure represented the nadir of a decline in numbers of marriages from 1930 at which time the Depression had started to bite hard. In other words, it was the end of the Depression which signalled the beginning of an increase in the numbers of marriages and a rise in the birth-rate, rather than a growth in perception of the values of a new social order which fostered a strident population policy. ${ }^{5}$ Therefore an increase in the numbers of births might have been expected to occur in any case even in the absence of economic inducements and the

l. St. J., 1937, p.37.

2. Ibid.

3. Ibid.

4. Ibid.

5. Glass, Population Policies, pp.269-272. 
pro-natalist propaganda of the Nazi government. Even though the monetary aid provided by the Marriage Loan scheme produced results in terms of numbers of marriages contracted, there was no really significant rise in marital fertility which was arguably the main purpose of such schemes. There would be no return to the levels of the early part of the century when the birth-rate showed figures per thousand of the population of between 29.8 (1910), and 33.1 (1906). Perhaps only similarly high rates could have been regarded as a revolutionary reversal of the declining rates. ${ }^{1}$ But this was beyond the power of the Nazi (and possibly any other) government to achieve and it had to make itself content with something far less than that, with figures which could be seen as a return to pre-depression levels of the mid nineteen-twenties. ${ }^{2}$

Birth-rate from $1920-26$ and $1929-36$, per one thousand of the population - live births only.

\section{$\underline{1920-1926}$}

$1920-25.9$

$1921-25.3$

$1922-23.0$

$1923-21.2$

$1924-20.6$

$1925-20.8$

$1926-19.6$

\section{$\underline{1929-1936}$}

$1929-18.0$

$1930-17.6$

$1931-16.0$

$1932-15.1$

$1933-14.7$

$1934-18.0$

$1935-18.9$

$1936-19.0$

A clear assessment of MuK and its policies is, as has been suggested above, made more difficult given that the new welfare

1. St. J., 1937, p.37.

2. Ibid.; Stephenson, 'Reichsbund der Kinderreichen', p.369.

3. St. J., 1937, p.37. 
measure was put into operation almost at the same time as the upturn in the German economy. Therefore one must treat with caution the claims of the officials of the Muk who usually claimed a major role for their policies when discussing the question of the 'success' shown in the rising birth-rate of their pro-natalist measures. ${ }^{1}$ The improvement in the numbers of second and third children born to women from 1933 (increasing from 54.0 to 67.7 per thousand women of child-bearing age between 1933 and 1934) only shows a return to the figures of eight years previously, that is to say, before the Depression. 2 For this reason, it is possible to say that, even without the various Nazi pro-natalist measures, such figures would more than likely have been achieved when unemployment began to disappear .

By 1938, only one family in thirty had four or more children under the age of fourteen, and even fewer, only one in every hundred families, had five children or more. ${ }^{3}$ Out of a number of just over sixteen and a half million women of child-bearing age in 1938, four million three hundred and fifty-two thousand, just under one quarter of these, were involved in attending some form of Nazi social welfare scheme. That is, 500,000 women attended the DFW's Reichsmutterdienst courses while 3,852,160 attended an MuK clinic during that year. ${ }^{4}$ By 1938, therefore, a fairly substantial attendance of women in MuK clinics and RMD courses had failed to

1. HA, 13/259, 'Artikeldienst', 'Der Sieg des Lebenswillens'; BA, NSD 30/4a, NS-Volksdienst, December 1933, p.167.

2. St. J., 1938, p.47.

3. Stephenson, 'Reichsbund der Kinderreichen', p.368.

4. Stephenson, Women in Nazi Society, p.165; BA, NS 26/261, 'Aufkommen und Verwendung', p. 31 . 
provide the kind of success which the Nazi population policies had been designed to secure, that is, the persuading of women to return to the practices of an earlier period: (1911) when out of every 1,000 women of childbearing age, as many as 100 had produced a fifth child. ${ }^{l}$ But this development needed to be based within a general figure of approximately 128.0 live births per thousand women as in $1910 / 11$, not 77.1 or thereabouts, as in $1938 .^{2}$ It was hopelessly unrealistic to expect a return to the high figures of the turn of the century, which themselves showed a drop from the higher figures of the decades of the 1870 s. ${ }^{3}$ Nazi population policies grounded as they were in irrationality, with their vicious promotion of 'racial purity', could not succeed in reversing what might be described as the irreversible. The falling birth-rates in western Europe were part of a demographic development which governments had little chance of moulding, or altering in a really significant way. ${ }^{4}$ Only an improvement in the infant mortality rates was capable of securing an improvement in the numbers of infants surviving, and also perhaps through an increase in the numbers of live births, through improved ante-natal care. An examination therefore of the infant mortality rates is perhaps a more useful way of deciding how successful the maternity and infant care of the NSV was. 5

In 1913 the infant mortality rate was 15.1\% (not including

l. St. J., 1938, p.47.

2. Ibid.

3. Ibid., 1937, p.37.

4. Glass, Population Policies pp.145-269.

5. St. J., 1938, pp.66-57;

BA, NSD 30/11, Informationsdienst, November 1938, Teil IV:

'Statistik', p. 29; pp.42-43. 
still-births). ${ }^{1}$ By 1937 , this rate had fallen to $6.4 \%$, a substantial improvement over the 1913 figure; but in 1933 the rate had already fallen to $7.7 \%$, so that the measures of the Muk were introduced at a time when such rates were falling in any case. ${ }^{2}$ The post-neonatal mortality rate (a rate normally calculated of deaths between four weeks and one year) had also been falling steadily from 1910/14 in * Germany, from 18.3 per hundred live births to 7.7 in $1933 .^{3}$ Between 1933 and 1934, this figure was reduced to 6.6 but thereafter it remained static up to and including 1936. In other words, there was a marginal improvement in such rates from the time that the Muk became established. The neonatal mortality rate (deaths occurring within the first month) improved slightly between 1934 and 1936, falling from 4,109 deaths in every 100,000 males born in 1934, to 3,932 in 1936; the figures for the female infant neonatal mortality rates were 3,241 in 1934 , and 3,092 in $1936 . .^{4}$ In specific areas including Berlin, the infant mortality rates were stabilising around a figure of $6.6 \%$ from $1933 / 34$ until the start of the war. In Berlin the infant mortality rate went up slightly, from $5.9 \%$ to $6.4 \%$ between 1934 and $1935 .^{5}$ However, this latter figure was still an improvement over the rates for 1932 and 1933, these showing 6.7\% and 6.8\% respectively. Other areas too showed at first a fall, and then a rise in 1935. In areas such as Saxony, Wurttemberg, Baden and

1. St. J., 1938, p.66.

2. Ibid.

3. Ibid.

4. Ibid., p.67.

5. BA, NSD 30/11, Informationsdienst November 1938, p.42. 
Thuringia a fall in the infant mortality rates was experienced between 1933 and 1934, and then a slight rise between 1934 and 1935 . These figures (as well as those for Berlin) can be seen as follows:

\section{$\%$ Infant Mortality Rates 1933/35}

$\begin{array}{lccc} & \begin{array}{c}1933 \\ \%\end{array} & 1934 & 1935 \\ & \% & \% \\ & 6.8 & 5.9 & 6.4 \\ \text { Berlin } & 6.3 & 5.2 & 5.4 \\ \text { Saxony } & 6.1 & 5.7 & 5.8 \\ \text { Werttemberg } & 6.6 & 6.0 & 6.3 \\ \text { Baden } & 7.2 & 5.6 & 6.2(1) \\ \text { Thuringia } & & & \end{array}$

While these figures show only a very slight movement upward between 1934 and 1935, actually showing the same hiccup in the rate of decline which had occurred between 1928 and 1929, it can be seen that the efforts of MuK were managing only to hold the infant mortality rates still, and in some cases, not even that. It seems likely that the Nazi measures were unable to make an impact on what seems to have been a slowing down of the fall in the infant mortality rates from $1929 .^{2}$ The effectiveness of Nazi maternity and infant care certainly comes into question given the almost static figures of the post-neonatal infant mortality rates between 1934/36. These rates had improved hardly at all with infants continuing to die during this period, for each month of life, at the same rates, up to the age of one year. For example, in 1934 - but also in 1936 - 335 out of every 100,000 male infants failed to survive the sixth month. ${ }^{3}$

1. Ibid.

2. Ibid., calculated from table of figures of infant mortality rates by Lander/Landesteile, p. 42 .

3. St. J., 1938, p.67. 
Girl infants in 1934 and 1936 showed a rate of 258 and 256 per 100,000 dying within the sixth month. While it is possible that these rates were close to reaching an irreducible minimum, it seems that the efforts of the Muk had been only marginally effective. The neonatal and post neo-natal mortality rates came under the scrutiny of the Berliner Akademie fur arztliche Fortbildung in 1941, when they published in one of their own journals the rates from 1932 to 1937. ${ }^{1}$ This was shown as follows:

Infant deaths: neonatal/post-neonatal rates from 1932/37

Deaths/One Month

Deaths/2-12 Months

$\begin{array}{rrrrrrr}\text { Year } & \text { Boys } & \text { Girls } & \text { Total } & \text { Boys } & \text { Girls } & \text { Total } \\ 1932 & 23,350 & 17,612 & 40,962 & 20,549 & 15,940 & 36,489 \\ 1933 & 22,625 & 17,017 & 39,642 & 19,296 & 14,345 & 33,641 \\ 1934 & 24,837 & 18,340 & 43,177 & 20,030 & 14,641 & 34,671 \\ 1935 & 26,393 & 19,124 & 45,886 & 23,555 & 17,208 & 40,763 \\ 1936 & 25,873 & 19,124 & 44,997 & 22,874 & 16,731 & 39,605 \\ 1937 & 24,676 & 18,414 & 43,090 & 22,632 & 16,472 & 39,104\end{array}$

These figures, as the article points out, did not present an encouraging picture, but even showed a rise in 1937 over the figures for 1932 - however, it was to be remembered the article emphasised, that the numbers of live births had also been rising steadily from 1932 so that these figures in themselves did not represent an overall rise in the annual infant mortality rates. ${ }^{3}$ The infant mortality rates for the years $1932 / 1937$ per 100 live births, were as follows:

1. BA, R18/3814, 'Die SAuglingssterblichkeit in den Jahren 1932 bis 1937'. (Title of publication unknown), pp. 47-48.

2. Ibid., p.47.

3. Ibid. 


$\begin{array}{ll}7.9 & 1932 \\ 7.6 & 1933 \\ 6.9 & 1934 \\ 6.8 & 1935 \\ 6.6 & 1936 \\ 6.4 & 1937\end{array}$

However, it is clear that in the period between 1939 and 1943 in the Gau Westfalen-Nord in the Kreis Beckum, the infant mortality rates had been rising steadily from a high 7\% to the even higher figure of $9 \%$, a fact which the head of the Kreis office for people's health was most concerned to have to report to the Gau office in March $1943 .^{2}$ This increase in the infant mortality rates in the area was, however, accompanied by a serious and steady decline of the birth-rate, another matter for concern at this time, which had prompted the setting up of an advice centre for childless couples in MUnster. ${ }^{3}$ An increased effort to get all pregnant women in the area to obtain NSV dietary supplements was reported to be underway and unmarried mothers and their new babies were to be given as much help as was available. The household help scheme too would be called upon in all needy cases, which suggests that such help might not have been as readily available in Westfalen-Nord up to then, though this specific point was not made. ${ }^{4}$ It certainly seems that an examination of local areas may be the only way in which specific claims of the NSV can be put to the test, given the variation in the figures of

1. Ibid.

2. BA, R18/3781, 'Amt fur Volksgesundheit an das Gauamt Kreis Beckum, Monatsbericht fur February 1943', 9th March 1943.

3. Ibid.

4. Ibid. 
infant mortality rates throughout the country. By 1939, the infant mortality rate had fallen to $6 \%$, and it was to be hoped, as Dr. Conti pointed out in his speech regarding the health of the population in 1943, the fifth year of the war, that it would be reduced further after the war - to $4 \%$ or thereabouts. ${ }^{l}$ The war-time infant mortality rates, he admitted, had shown a marked tendency to rise, this was for various reasons, including an increase in digestive illnesses and the increase in the numbers of air-raids. In 1943, the rate was $7.7 \%$, but showing a tendency at that time to fall slightly, so that it had become all the more urgent to evacuate from the cities as many pregnant women as possible. ${ }^{2}$

At a time of a growing effort by the Muk, the almost static figures of the infant, neonatal and post-neonatal mortality rates were mirrored in the death rates from 1931 to 1935 of small children from the ages of 3-6 years, though not for those aged 1-3 years, more of whom were surviving in 1935. Both accident and serious illness, mainly lung infections, were seen to be taking a toll of the older age groups with as much as 30\% of deaths of older children in 1935 being due to accident alone. ${ }^{3}$

1. BA, R18/3805, report of Dr. Conti, Stand der Volksgesundheit im 5. Kriesgsjahr, Berlin-Wien, 1944, p.12.

2. Ibid.

3. BA, NSD 30/11, Informationsdienst 1938, p.29. 
$\%$ of Deaths of children aged between one to six years

from $1931 / 1935$

$\begin{array}{cccccc}\text { Age } & 1931 & 1932 & 1933 & 1934 & 1935 \\ & \% & \% & \% & \% & \% \\ 1-2 & 12.6 & 12.1 & 11.0 & 10.5 & 10.9 \\ 2-3 & 6.0 & 6.0 & 5.8 & 5.5 & 5.1 \\ 3-4 & 4.4 & 4.5 & 4.3 & 4.5 & 4.1 \\ 4-5 & 3.5 & 3.5 & 3.7 & 4.1 & 3.8 \\ 5-6 & 3.3 & 3.2 & 3.1 & 3.5 & 3.4(1)\end{array}$

Bombastic statements which senior NSV officials were fond of making, which underlined how the NSV should be regarded as having a parental function, failed to point out that such 'parental' care frequently missed the mark and only provided a watchful eye rather than real welfare care as such. ${ }^{2}$ Interference by the NSV within the lives of young women, who were roped into the RMD courses or were persuaded to attend the Muk clinics, may have been the main or even the only success of which the NSV could genuinely boast. The process of interference and involvement within the socialisation process (in the secondary phase) of young people, starting as it did with the formation of the $\mathrm{HJ}$, was further extended by the NSV's involvement in the organisation of a training scheme for motherhood. ${ }^{3}$ The NSV/MuK intended to alter the manner in which child-care skills were

1. BA, NSD 30/11, Informationsdienst 1938, p.29.

2. BA, NSD 30/4a, NS-Volksdienst, 1943, p.163.

3. For a clear explanation of the process of secondary socialisation, see Peter L. Berger and Thomas Luckman, The Social Construction of Reality, London 1971, pp.157-166. 
learned through the provisions of the RMD courses and the MuK clinics. Skills which had earlier been picked up in an ad hoc manner through contacts with older women family members were, from 1934, intended to be transmitted primarily through the DFW and the NSV. Such interference showed itself too in the changes which were made in the school curriculum after 1933 when, in the senior schools, the provision of domestic science was extended at the expense of mathematics, science and languages. ${ }^{l}$ It was not so much that an intention existed whereby most women would be turned into housewives and mothers rather than doctors or scientists, but that those who were going to take up the occupation of motherhood would be trained as never before to carry out their traditional duties. ${ }^{2}$

The dissemination of sentimentality as well as rationality within NSV pro-natalist propaganda reveals that a double-sided attack upon the perceptions of women would be launched. The sentiments contained in tear-jerking articles and poems about a mother's love, were meant to be taken in along with advice about good hygenic practices in infant care. This was no doubt to impart a 'rounded' approach to the whole question of learning about motherhood, an activity intended to relate closely to the values of the Volksgemeinschaft. These two particular emphases would support and maintain the goal of racial purity and the drive towards securing the birth of 'Aryan' children. For those women who had previously

1. Stephenson, Women in Nazi Society, pp.116-128.

2. Jill McIntyre (Stephenson), 'Women and the Professions in Germany, 1930-1940', in A. Nicholls and E. Matthias (eds.), German Democracy and the Triumph of Hitler, London, 1971, pp.205-209. Scholtz-Klink, Mutterschulung in Deutschland, p. 143; BA, NSD 30/7, Ewiges Deutschland, May 1937, 'Eine Wanderlehrerin des Reichsmutterdienstes im Deutschen Frauenwerk erzahlt', p.12-14; c.f. V.R. Berghahn, Modern Germany, Cambridge 1982, pp.138-141. 
undertaken the activity of housewife and mother without consciously being aware of the 'significance' of this occupation for the nation as a whole, NSV and MuK propaganda would ceaselessly point up the necessity of considering the needs of the community above, and before, those of the individual. ${ }^{1}$ The numbers of women being encouraged by the DFW to re-think the role of mother within Nazi society came to five million by 1944 . They had attended RMD courses numbering thirty thousand in all, and at a rate of approximately 500,000 yearly from 1934. By 1941, the Muk clinics were being visited by just over 10 million in one year which means that just under 11 million women in 1941/2 were being taken into the welfare facilities of the MuK and RMD together. ${ }^{2}$ By 1942, 36.3 million women had passed through the MuK clinics and advice centres altogether. ${ }^{3}$ In spite of all of this effort and expense, which had not come out public funds but those of the private donations to WHW, the birth-rate of 1942 was recorded at 15.2 live births per thousand of the population. ${ }^{4}$ This war-time figure was higher than the one recorded during the Great War, as the Nazis themselves boasted, but it was also the same as the one recorded at the time of the Depression in 1932 when the birth-rate was regarded as being at an all-time low. ${ }^{5}$ Perhaps the infant mortality rates, which seemed to have remained at about 6.4 and 6.6 per hundred live births until 1943, showed that a marginal success could be chalked up by the Muk.

1. Erich Hilgenfeldt, Idee, 'Der nordische Gedanke in der Wohlfahrtspflege', pp.19-31.

2. Stephenson, 'Women in German Society, 1930/40', p.378.

3. BA, NSD 30/4a NS-Volksdienst April 1942, p.74.

4. Stephenson, 'Reichsbund der Kinderreichen', p.367.

5. Ibid.; St.J., 1937, p.37. 
However, given that maternal mortality rates must also be included in an assessment of successful maternity and child care, until these are examined, it is clearly impossible to give more than a tentative appraisal of MuK facilities. According to Dr. Conti, the maternal mortality rate for women after giving birth had fallen during 1940 from 1 in every thousand to 0.6. The rates for 1936 had been 100 deaths due to child-bed fever in every 100,000 after giving birth; this figure had fallen to 60 in every 100,000 in $1943 .^{1}$

The chief successes which Muk could claim were the free holiday schemes which proved to be both popular and successful, providing as they did holidays for those whose income could not meet the extra expense of a much-needed vacation. ${ }^{2}$ Muk welfare in the form of a hand-out to the needy of food supplements, and other donations in kind, on the other hand seems only to have been regarded as a stop-gap until a better income could be achieved, and was less welcome because of that and certainly less popular than Muk officials intended they should be. An improvement in the birth-rate, which was meant to be one of the main functions of the Muk, seemed to exist to the extent of a return to the figures of the pre-Depression period rather than of a substantial rise in the figures as such. ${ }^{3}$ It also seems as though the improving infant mortality rate had reached something close to its optimum level, in any case, with the MuK apparently unable to encourage a further move downward in these

1. BA, R18/3805, Stand der Volksgesundheit, p.11.

2. BA, NS 22/261, 'Aufkommen und Verwendung', 'Mutterverschickung', p.31.

3. St. J., 1937, p.37.

Kershaw, 'Popular Opinion', pp.95-103;

Stephenson, 'Reichshund der Kinderreichen', p.369. 
figures before the war. During the war itself the infant mortality rate began to creep upwards again so that the welfare aid provided by the MuK was unable to hold the figures steady, certainly by 1943 at least. Maternal mortality rates seem to have been improving slightly for they were not rising in war-time; however, this issue must be gone into in greater detail before a conclusion can be reached. In addition, the provision of Muk welfare, even when it was distributed in the form of a daily help, did not necessarily persuade women to take on the burden of another pregnancy, especially so since many women were returning to the factory and the office from 1933/34. ${ }^{1}$ During the war, propaganda which was designed to persuade women to return to work in order to contribute to the war effort was singularly unsuccessful, even though Muk welfare would be available to working mothers in the form of a daily help during short periods of need, when circumstances proved to be making life intolerable. ${ }^{2}$ It seems clear that the more 'successful' aspects of mothercare training in Nazi Germany was its ability to interfere in the lives of women, for they had to open up their homes and reveal their kitchens to the scrutiny of RMD officials (when undertaking a course in child-care), in order that areas of 'inefficiency' could be pinpointed. $^{3}$ But it seems that there was little that the government could do to influence women to produce more and more children, even though emphatic pro-natalist propaganda was continually supplied through the MuK and the RMD. Women who had completed their families

1. Berghahn, Modern Germany, p.140.

2. Stephenson, Women in Nazi Society, pp.156-172.

3. Scholtz-Klink, 'Mutterschuling', p.143. 
were not persuaded by arguments to consider the needs of the nation before their own, and they would continue to restrict the number of children born to manageable proportions, in spite of continual reminding to do the opposite. ${ }^{1}$

1. St. J., 1938, p.67.

Stephenson, 'Reichsbund der Kinderreichen', p.367. 


\section{THE YOUTH WELFARE SECTION OF THE NSV}

In 1934, the NSV set up a section for youth welfare. This was the NSV-Jugendhilfe (NSVJ) and it was intended to function as an addition to the existing arrangements for child and juvenile care which was then being carried through by the state welfare system. ${ }^{1}$ To the extent that the NSV's own youth welfare facilities had to fit in with the existing state system, it was closely involved with the work of the state youth welfare offices at all times. For this reason a study of Nazi youth welfare may be viewed also as a case study of the impact of Party and state rivalries upon a substantive area of social welfare from 1933. The following chapter can only be regarded as an initial examination of the organisation of youth welfare in Germany after 1933, for this requires not only a long study devoted to itself which would examine the problems of Party and state cooperation, but also the involvement of the churches as well. For this reason, the following sections can only be regarded as a preliminary study of the German youth welfare system from 1933/34.

The Party organisation's own youth welfare section operated completely independently from the Hitler Youth which itself carried out a programme of youth care. Indeed, the war would see the two organisations coming more closely together in the work of correctional education. The jurisdictional problems which sometimes arose between the $\mathrm{HJ}$ and the NSVJ were nevertheless totally eclipsed by the serious problems which would stubbornly continue to arise

1. Friedlunder and Myers, Child Welfare in

Germany, pp.1-24. 
between the NSV and its youth welfare section and the leading officials of the state Jugendamter. But the NSVJ would nevertheless be forced to cooperate, however reluctantly at times, with leading state officials who were in a position of some power over the delegation of suitable cases to the NSVJ. Inevitably, youth welfare in Germany after 1933 would exist as a double-sided provision of Party facilities on the one hand, and those of the state's on the other. Given the inherent contradictions which arose out of the very nature of Party/state relations, youth welfare would be bedevilled by the appearance of conflicting sets of proposals and counter proposals coming from both NSV and state officials. Not until the war would a more fruitful cooperation emerge in new formal agreements, though at local level often enough these would be seen as unworkable. From the beginning, jurisdictional problems would come to vitiate the efficient provision of welfare within the youth care measures of party and State; perhaps inevitably, problems between rival officials would assume greater importance than the actual practice of youth care itself.

As its newly created organisational framework indicated, the NSVJ intended to achieve a powerful position in relation to the existing social welfare system. ${ }^{1}$ The NSVJ had been created ten years after the post-war developments of the Weimar system of

1. BA, NS 25/1162, discussion documents Hauptamt fur Kommunalpolitik, 'NSV und Gemeinden'; 'Gemeinden und NS-Volkswohlfahrt, 1942; $B A, R 36 / 1002$; 1003, see documents with reference to discussions by the officials of the DGT over a proposed NSV assumption of control over ' $\mathrm{dffentlichen} \mathrm{FUrsorge'} \mathrm{.}$ (public assistance), 1938/39. 
youth welfare, albeit one which had suffered severe restrictions in the years of the Depression. Nevertheless, even allowing for some later reductions in the new arrangements, youth care had experienced a complete overhaul of its organisational and operational procedures when the new law of 1922 was put into force. The law of 1922 the Reichsjugendwohlfahrtsgesetz (RJWG) was of great importance to the NSVJ in planning its new tasks. Given that the new government in 1933 had substantially retained these legal arrangements, they were of some significance to the NSV officials who were required to organise and to set up the new youth welfare measures. It is for this reason that it is necessary to outline the shape of the Weimar facilities in order to understand more easily how welfare for young people was organised through the NSV, but also the state, from $1933 .^{1}$

In the first few years after the Great war there had taken place a reorganisation of the whole system of social welfare. In 1924 the Social Welfare Decree (Reichsfursorgepflicht) had aimed to provide the legal framework within which new welfare facilities would be made available to the most needy. Poverty and distress, some had come to realise, were perhaps mainly attributable to the impact of economic circumstances rather than to individual fecklessness. ${ }^{2}$ State welfare was enlarged and it was grouped into three branches:

1. Friedlünder and Myers, Youth Welfare in Germany, see Chapter Three, 'The Legal Basis of Child Welfare in Germany', pp.5-25. Elizabeth Harvey, St. Antony's College, Oxford, see unpublished Conference Paper, June 1984, 'Youth Welfare in the Final Phase of the Weimar Republic'.

2. Wunderlich, Farm Labor in Germany, pp.144-145. 


\section{1. economic assistance; \\ 2. youth welfare; \\ 3. health welfare.}

It certainly seems as though this particular decree was also retained after 1933, but it was the Reichsjugendwohlfahrtsgesetz to which NSVJ officials would make frequent reference, rather than the law for social welfare.

In line with the general reorganisation, it was decided after the Great War that the existing system of youth care should be extended and completely overhauled. Given the greatly increased numbers of needy young people in the post-war period, it was recognised that the facilities of the uncoordinated arrangements of church and, only marginally, state provisions then in existence could no longer be expected to meet the demands of an increasing need for child and juvenile care. The knowledge that the war had created many orphans and fatherless children also generated a growing concern about the need to protect and support them. The intention to expand and reorganise was therefore part of the current changes taking place within the welfare system as a whole. The participation of the state in the system of youth welfare would be designed with the cooperation of the officials of the existing private agencies of the churches and other independent bodies such as the Red Cross in mind. To some extent the continued participation of the churches after 1933 was firmly secured by these legal provisions, for there would remain after 1933 a willingness as well as the necessity, to make use of
1. Ibid.
2. Ibid., p.145. 
church facilities; state officials, as before, would continue to direct welfare cases to church institutions and other facilities when the occasion arose. ${ }^{l}$ The willingness of Nazi officials after 1933 to use them was in many cases as much a matter of habit as of anything else. ${ }^{2}$ This aspect of the Weimar youth welfare system would later show a particular resistance to change even in 1939 when the churches had been prevented from participating in certain important areas of youth care. $^{3}$ The Reichsjugendwohlfahrtsgesetz, which had intended to secure a cooperative partnership with the Jugendamt, the protestant Innere Mission, the Catholic Caritas, and other agencies, can be seen to have fulfilled many of its intentions given the difficulties inherent in trying to make changes later, in the middle and late nineteen thirties.

Before 1933, state facilities had been intended not only to be participatory in nature but also democratic in intent. The domination of the private charitable agencies would come to an end in 1924, and from that time the Jugendumter would undertake to provide an expanded system of care (albeit reduced in time of severe economic difficulty). ${ }^{4}$ State officials, some of whom would later fight tooth and nail to retain their own continuing participation, administered the system of juvenile care, and it was the Jugendamt which would have the duty of coordinating all this work. ${ }^{5}$ Commenting on the

1. BA, NS 25/405, Bormann to Frick, 'Auslegung des Reichsjugendwohlfahrtsgesetz', letter of 9th December 1935.

2. From 1934 the state Jugendamter continued to make use of church facilities according to the provisions of the new law of 1922. These were often much cheaper than NSV facilities.

3. BA, R36/974, Hilgenfeldt to DGT, letter of lst October 1937.

4. Friedlunder and Myers, Child Welfare in Germany, pp.1-14.

5. Ibid., pp.6-7. 
provisions of the new law, Dr. Gertrud Baymer, a senior government official until 1933, praised the essential idea which lay at the centre of its intentions: ${ }^{1}$

'The National Child Welfare Law which became effective on the lst April 1924, is an attempt to increase achievement through purposeful centralisation. It brought together the already existing public child welfare activities and delegated them to one official body, the Jugendamt. It went further however and included the entire private activity in the field of child welfare, combining it with the public in definite fashion. Private child welfare activities are not only represented in the governing committee of the youth welfare office, but the youth welfare office is expected to encourage the private agencies to cooperate actively and to make of them an adaptable agent for carrying out particular activities.

The Weimar arrangements were intended to secure the longestablished and valuable contribution of the churches and sought to retain what amounted to a wealth of experience within the whole area of child and youth care. ${ }^{3}$ However, not only would the churches continue to function after 1933, but they would, additionally, be expected to take on part of the responsibility for the care of those rejected by the Party welfare organisation, whether these were on the grounds of 'diminished responsibility', or other unacceptable categories such as the 'unworthy', 'asocial' or 'biologically inferior' ones. ${ }^{4}$ The NSV issued guidelines on this and care would be taken in the youth welfare section to include only the 'worthy' cases

1. Ibid.

2. Ibid.

3. Ibid.

4. BA, NS 37ii/1031, Hilfswerk MuK, 'Richtlinien fur die Beurteilung der Erbgesundheit', 14th October 1940. BA, NS 25/1199 (fol.1), Guidelines/ Agreement, NSV/Jugendamt, over the work with 'erbgesunden', 'erziehbaren', 'rassisch', 'wertvollen' Jugendlichen, 1941. 
within the framework of the youth care of the Party. But the familiar system of church/state facilities would not disappear; it would very largely remain, and be recognisable to state officials who would continue to organise the state subsidies for both Innere Mission and Caritas. $^{1}$

On the governing boards of the state Jugendamt before 1933 were included representatives from the non-religious charitable agencies as well as ministers of religion, officials of the Red Cross, the political parties and other independent groups involved in the provision of organised arrangements for the care and well-being of juveniles. $^{2}$ It was through this particular legal provision that NSVJ representatives would have an opportunity to participate in meetings (from 1934) of the Jugendamt boards, mainly, as observers. This opportunity to participate would, however, not give any particular advantage to the NSV, either in its claims for greater participation in the work of youth care, or in its relations with the officials of the Jugendamter themselves. ${ }^{3}$ When in 1939 new 'advisory' committees were formed from which the ministers of religion were excluded, these would fail to provide a forum from which a greater degree of cooperation could develop. One may argue that lack of participation on the new committees did not signify, even for the churches, a particular loss of potential influence, for such participation was in any case enervated by the process of Gleichschaltung which had removed the decision making function,

1. $\mathrm{BA}, \mathrm{R} 36 / 962 ; 964$.

2. Friedlander and Myers, Child Welfare in Germany, pp.5-21.

3. BA, R36/1418, 'Zusammenarbeit der Jugendümter mit der NSV', guidelines of 28th October 1938. 
transferring it upwards to the most senior officials of the $\underline{\text { Jugendamt }}^{1}$

The primary and compulsory duties of the state Jugendamter, ones which would largely remain, apart from certain alterations in favour of the $\mathrm{HJ}$, were as follows:

1. The foster-care of homeless children

2. Matters pertaining to guardianship of minors

3. Care of children in need

4. Assistance in the Juvenile courts

5. Protective supervision

6. Correctional Education

7. Cooperation in probation work

8. Supervision of the work undertaken by minors

9. Cooperation with war veterans' Bureau in the care of orphans and children of persons injured in the war

10. Cooperation with police officials in the treatment of juveniles through supervision with a view to preventing unnecessary cases being taken into police custody

There existed a number of secondary (voluntary) duties which included:

1. Counselling in matters affecting children and young persons

2. The care of expectant mothers

3. The protection of infants and children of pre-school years

1. Friedlünder and Myers, Child Welfare in Germany, pp.15-24. The DGT and Fiehler had responsibility for making all top level decisions. See also BA, R36/1002, 'Aufzeichnung zu der Frage

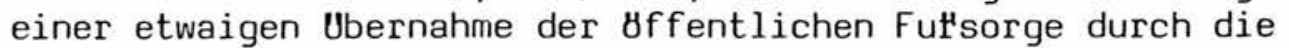
NSV', report of August 1939. 
4. The protection of children of school age

5. The protection of children who are no longer in school.

After 1934, the Party agency would be involved in the work which referred to the first set of responsibilities, but in a voluntary and a participatory manner only, for the NSV would not be legally bound to provide social welfare measures in the light of its frei status. ${ }^{2}$ Nevertheless, the NSV would also be involved in measures with regard to the second list from 1-3; the section NSVJ would include the last categories within its own particular frame of reference. Fursorge or remedial welfare measures would remain to be a prime responsibility of the state, both before and after 1933, and the NSV would be viewed as being able to offer its facilities as a participatory contribution to that of the state agency. From this point of view, FUrsorge would remain a prerogative of the state. Most notably in this respect would be FUrsorgeerziehung (hereafter FE) which was the most custodial of all the measures; eventual NSV participation in this work (which included the transferral of cases to reformatories for the purpose of receiving 'correctional' education), would be limited to acting as a support for those cases assigned to Aussenfursorge. 3

1. Friedlander and Myers, Child Welfare in Germany, pp.9-10.

2. BA, R36/962, Ministerial 'Erlass' (RMBL. V.S. 1514) 12th September 1938. See Chapter Two.

3. BA, R36/1996, Amt fUr Volkswohlfahrt Gau Kurhessen; Hessen-Nassau, 'Richtlinien fur Beaufsichtigung von Kindern und Jugendlichen die in FUrsorgeerziehung oder in freiwilliger Erziehungshilfe untergebracht sind'. n.d. (?1939); Ibid., instructions from the Jugendamt Wiesbaden to Oberpr Hsident Hessen-Nassau, 'Aussenfursorge in der Fursorgeerziehung', with regard to RMdI 'Runderlass' of 24th June 1939, 17 th June 1939. 
But it is not clear how 'serious' these cases were in terms of treatment required and the more difficult cases would of course be sent to a reformatory or other similar facility, not to an NSVJ Home. Often enough these would be run by the church agencies for they had a long history of such work and would continue to be involved after 1939. The NSV had neither facilities nor staff for the full application of correctional education and it would not be until 1943, at the earliest, that the NSV would become involved - even then still marginally - in such work, although preliminary attempts to become more closely involved in $\underline{\mathrm{FE}}$ were made during $1941 .^{1}$ To some extent the NSV would exist rather more in the manner of an agency which was well able to provide Jugendpflege, or recreational care for juveniles; when it also provided vorbeugende (preventive) care, it made what state officials regarded as being a worthy contribution. Had the NSV been content to do only that then the history of juvenile care after 1933 would have been quite different.

Before the Nazi takeover of the youth care facilities of the Jugendamter, which would be later organised and run by trusted Nazi civil servants and other state welfare officials, there had occurred a serious, even damaging curtailment of facilities due to the Depression. This had the effect of allowing interested factions to emerge who fostered particular emphases which had the effect of introducing measures which by their use of selective processes pre-dated certain inhumane practices of the NSV. Most notable of these was the exclusion of certain types of 'less responsive' cases

1. BA, R36/1996. See correspondence August/September 1941; Ibid., Verwaltung des Provinzialverbandes Kiel, Landeshauptmann, Dr. Schow to DGT, 'Zusammenarbeit zwischen Fursorgeerziehungsbehछrden und NSV-Jugendhilfe' report of 12th August 1941. 
from the expensive facilities of $\mathrm{FE} .{ }^{1}$ It seems as though in 1929/30 many $\underline{F E}$ cases were released mainly in response to necessary cuts in welfare funds, rather than on the basis of treatment completed. FE itself was drastically reduced through selection procedures which excluded the more hopeless cases. ${ }^{2}$ The financial crisis encouraged a reduction of state participation in favour of that of the churches, so that the 'balance' between state and non-state facilities altered once more. This development did not dismay the Red Cross who looked forward to an increase of the work of the independent, non-state agencies once again. ${ }^{3}$ Indeed it has been argued in a recent study of youth welfare in Weimar that the earlier balance between state and private/non-state youth care, and the provisions of the law itself, had been achieved only out of a hard-won compromise between prominent liberal and social democratic reformers, radical left-wing social workers and right-wing politicians. ${ }^{4}$

1. Harvey, Youth Welfare, pp.1-6.

2. Ibid., p.17.

3. Ibid.

4. Ibid., p.6. 
The Organisation of the NS-Jugendhilfe

The creation of the NSV-Jugendhilfe in 1934 finally provided the new Nazi welfare organisation with a fully comprehensive programme of social welfare. At head office in Berlin the youth welfare section Jugendhilfe was incorporated into Department III, Wohlfahrtspflege und Jugendhilfe, under the control of Herman Althaus. ${ }^{l}$ With the addition of a department designed to carry through measures according to Nazi doctrines for the care, guidance and general welfare of the young, the NSV had completed one of the last stages in its pre-war development. Arrangements were set up for the participation of full time and honorary staff in the work of the juvenile courts, the care of illegitimate children, protective supervision of juveniles, full abrogation of parental rights and the official guardianship of minors and, later, adoption procedures. ${ }^{2}$ All of these duties would of course continue to be carried out fully by the state Jugendamter which had prime responsibility for providing these by virtue of the law. The Jugendamter would now, however, find that they would have to make provisions for a cooperation with the NSV, and delegate to the NSVJ part of the work of juvenile care. The NSVJ would thus provide extra help which was, often enough, gratefully received. ${ }^{3}$

Once the organisation of the NSVJ had become established, more ambitious plans would begin to make themselves apparent. In choosing

1. See Chapter Two, p.44.

BA, NS37ii/1001 fol. 2. 'Organisation Plan'.

2. Ibid., 'Das Wesen der nationalsozialistischen

Volkswohlfahrt', 1936 pp.l-2.

3. BA, NS25/1162, 'Gemeinden und NS-Volkswohlfahrt', 1942, pp.1-2, such remarks refer only to the peace-time years. 
an initial form which was based on the state arrangements the NSVJ hoped to be able to assume a fully competent role in relation to all the legal responsibilities of the youth welfare offices, even though, as an independent organisation, it was required only to fulfil a supportive function. No precise requirement existed with regard to either its form or its provisions. These were worked out as NSV staff participated with the Jugendamt, so that it was a process in action, not a previously worked out plan, and such arrangements were meant to be supportive of the Jugendamter mainly. For example, it was impossible for the NSVJ to take up a case of $\underline{F E}$ without participating with and through the Jugendamt. ${ }^{1}$ Right from the start it was clear that Erich Hilgenfeldt and Hermann Althaus took very seriously indeed the NSV's incursion into the whole field of child and youth care. ${ }^{2}$

The organisation of the NSV-Jugendhilfe furctioned at Reich, Gau and Ortsgruppe levels, although not every administrative form was exactly duplicated throughout each one. At the level of the Reich, the Haupstelle Jugendhilfe which was within the head office of the NSV in Berlin, worked in direct contact with the Reich Ministry of the Interior. Within the Gaus, responsibility for all NSV youth welfare work was organised by a special Unterabteilung Jugendhilfe, and this special department was situated within the Kreis and Ort as well. At Gau level, the department was responsible for the systematic undertaking of all work carried out, indeed it acted

1. BA, NS25/1233, see RMdI 'Runderlass' of 1941, Section D., 'FUrsorgeerziehung'.

2. HA, $13 / 259$, 'Reichsrichtlinien fur die NSV-Jugendhilfe', 'Organisation', pp.16-19. 
as a 'check and command point' and gave instructions to the Kreis and Ort with regard to NSVJ measures. Unterabteilung Jugendhilfe was, in turn, responsible to head-office in Berlin, and to Althaus in particular. All correspondence with the leading administrative authorities, for example, the Reichsleitung or the Landesjugendamter was channelled through the Gau office itself. ${ }^{l}$ The NSVJ at Gau level also had the duty of making sure that a suitably trained official was present at any discussions which took place between leading Party officials of the Jugendamt and perhaps from the DGT as well. ${ }^{2}$ Gau staff were expected to exercise control over the work udertaken within the Kreisleitungen; advice and support from senior staff were made available to the Kreis offices especially with regard to problems over finances (a most important issue). Questions regarding the more troublesome welfare cases were referred to the specialist staff of the Gau office. However, since the Kreisleiter had the duty of advising and supporting the offices at Ort level too, a completely hierarchic al system predominated, and was designed to facilitate the 'filtering down' of expertise and advice. 3 However, all of this framework was regarded by state officials as being insensitive to needs at local level, and it showed itself to be unresponsive and slow to act; indeed they seemed to dislike the rigidity which had been built into the NSVJ organisational plan. This complicated structure had been designed, surprisingly enough, with economy of operation in mind. It was expected to be reasonably cost effective, that is, there would be a filtering down of expert
1. Ibid.
2. Ibid.
3. Ibid. 
opinion thereby avoiding the employment of too many expensive workers, or specialist staff, at each level. ${ }^{l}$ None of this would prevent, however, claims that the NSV was both inexperienced in the work of youth welfare (which it was), and proving to be employing too many voluntary, as opposed to paid and fully trained, workers who, even if they were instructed and guided by the Gau staff, were really not well-trained enough. ${ }^{2}$ The fact that the most experienced staff existed in the NSVJ Gau office with the duty to issue instructions down through each level was one which failed to impress most of the leading state officials who would continue to be concerned about the lack of expertise among NSVJ honorary welfare workers.

The Kreis office was responsible not only for passing on instructions to the Ort level, but for supervising and organising all training of the NSVJ voluntary and other staff. Most importantly, the Kreisleitung had the task of assuring, as far as possible, a coordination of all ideological/political training in order that work undertaken by the NSVJ staff was closely aligned with NSV welfare policies in general. ${ }^{3}$ The Kreis office was also expected to form a close cooperation with the Hitler Youth, an area in which it was not always successful, and also with the schools and the employment offices as well. It was therefore the Kreis office which handled day-to-day problems, operating at the sharp end of the provision of

1. Ibid.

2. BA, NS25/1233, Kreisamtsleiter fUr Kommunalpolitik, Kassel to DGT on increased NSVJ participation, 'Stellungsnahme zu dem Entwurf einer Vereinbarung zwischen Jugendamt und NSV'. n.d. (?1941).

3. HA, 13/259, 'Reichsrichtlinien', 'Organisation'. pp.16-19. 
NSV youth welfare. Recruitment of voluntary or honorary workers fell to the Kreis office too and it was expected that suitable persons would be drawn from every possible source; from the civil service, the teaching profession, the ranks of the women's organisation and in some cases, the League of German Girls. The essential qualities of the ideal NSVJ social worker were the ability, and the willingness, to put in many hours of unpaid labour. ${ }^{l}$ A fairly typical example of such a voluntary worker was someone who was just as likely to be fully employed during the day, as well as non-employed housewives. They would be expected to give generously of such free time as they could, both in the evenings and at the weekends, and to attend courses before taking up such work. If a man, he might be an NSV Blockwalter or part-time worker for the Winter Aid, and perhaps even a member of the SA too. ${ }^{2}$ By 1936, 34,291 trained staff of the NSVJ (who were all salaried) were occupied in running the 26 Jugendheimstatten and working in the 3,361 Erziehungsberatungs -stellen of the NSV's youth welfare section. ${ }^{3}$

A dependence upon large numbers of honorary helpers who made themselves available for social work duties with the NSVJ, meant that the NSV itself had a vested interest in promoting the values of selfless devotion to hard work which took little notice of individualistic or privately motivated concerns. Such activity was rewarded by being acknoweldged publicly by the NSV who printed photographs of the tireless workers of the Volksgemeinschaft in the journal Ewiges Deutschland. A short list of the achievements would

\section{Ibid.}

2. NSD 30/7, Ewiges Deutschland May 1937, p.30-31.

3. BA, NS $26 / 261$, 'Aufkommen und Verwendung' p.35. 
be described, and they were given as an example to follow, a sign the NSV declared, of that 'spirit of sacrifice' and service for the Volk which all citizens of Germany ought to emulate. ${ }^{l}$ At Ort level, where work was undertaken and organised within the office of the department Mutter und Kind, ${ }^{2}$ staff would be expected to support the Kreis office in the search for voluntary helpers whose suitability for these posts depended utterly upon 'political reliability' as well as proof of 'Aryan' descent. By the end of 1938, the NSVJ was employing 76,287 youth welfare workers, the majority of whom were men, that is to say $53,720 .^{3}$

The youth welfare policies of the NSV.

'Social work is concerned with social justice, social security, and consideration of individual needs and rights. These aims cannot be reconciled with the denial of political, civil and religious liberties; suppression of public criticism; encouragement of racial and national prejudice; or the complete subordination of the individual to the larger social unit'.

This statement was included in the first paper which was given at the Third International Conference on Social Work held in London in July 1936. It had little to do with the current practice or the philosophical direction of NSV social welfare in general; indeed the statement pinpoints that which had been lost to German social welfare after 1933, and the words were those of the American Chief of the

1. BA, NSD 30/7, Ewiges Deutschland, May 1937, pp.30-31.

2. HA, 13/259, 'Reichsrichtlinien', p.10. BA, NSD 30/2 NS-Volksdienst, 'Die ehrentamtliche Helfer

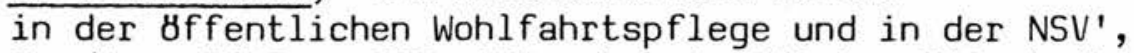
May/June 1938, p.252; 'Die ehrentamtlichen Mitarbeiterin in MuK', p.254.

3. BA, NSD/30/11 Informationsdienst, July 1939, p.177.

4. Report of the III International Conference on Social Work, London, 1936, London 1936, p.22. 
Children's Bureau of the U.S. Department of Labor who gave the paper to the first General Session of the London Conference. ${ }^{l}$ It is tempting to assume that the statement was made as an intentional and barely disguised challenge which the German delegates, including Althaus, Frau Scholtz-Klink and Erich Hilgenfeldt, who led the delegation, could hardly fail to register. By 1936, as the American delegates to the London conference no doubt realised, German youth care - of the Party largely, and of the state perhaps less so - no longer placed the needs of the individual at the centre of its specific measures. ${ }^{2}$ Even though there existed in the youth care section of the NSV a strong emphasis upon the need to 'educate' the young towards a sense of service, a sense of Opferbereitschaft, at the same time, juveniles would be supported and given care insofar as they were each regarded as a 'useful' part of the greater whole. In other words, the needs of the community would transcend those of its individual parts. While the fundamental relationship between community on the one hand, and its individual members on the other, was a subject which Althaus, Reher and even Hilgenfeldt puzzled over in both writings and speeches, such ideas were hardly new or original. But they had received in Germany after 1933 a new emphasis that was, if not original in conception, then utterly chilling in the ruthlessness both of the manner, and of the means, through which new

1. Ibid.

2. Reher, Social Welfare, pp.1-12;

BA, R36/1996 Dr. Schow to DGT, 12th August 1941. 
ideas about the Volksgemeinschaft would be put across. ${ }^{1}$

The London Conference in 1936 was made aware of the alteration and the shift of emphasis which had occurred in the German social welfare system after 1933. It was made clear to the international audience that the youth of the nation would be brought the benefits of welfare assistance on the basis of certain 'principles' viz, that individual needs even if they were of a serious nature, no longer occupied a central position in the German welfare system.

Following from these propositions, the starting point of all NSV juvenile care was held to be the larger social unit - in every case. As the NSV put it in the Zusammenstellung:

In the previous liberal system of youth welfare specific measures were considered from the point of view of the individual juvenile. National Socialist youth welfare will however consider the needs of the community in relation to juvenile welfare as a whole.

For this reason, Hermann Althaus in his paper Soziale Eingliederung in Deutschland which was written as a contribution for the London conference, began his first statement with that favourite, most repeated of Nazi statements, Gemeinnutz geht vor Eigennutz. ${ }^{3}$ But there seems no reason to doubt that, as head of the youth welfare section of the NSV, he meant it. In the measures outlined in the Zusammenstellung, the philosophical foundation of the NSV's youth welfare scheme was explained, and the opportunity was taken to

1. As Erich Hilgenfeldt put it, 'Nur ein gesundes, starkes Volk kann die Aufgaben erfullen, die der Herrgott uns als deutsches Schicksal stellt', Aufgaben der Nationalsozialistische Wohl fahrtspflege.

2. HA, 13/259, 'NSV-Jugendhilfe', 'Zusammenstellung', p.l.

3. Hermann Althaus, 'Soziale Eingliederung in Deutschland' in A Contribution III International Conference, pp.6-14. 
emphasise that NSV youth and child care had nothing to do with anything that had gone before. ${ }^{l}$ This was made only too clear when in the outline it was declared that only certain categories of the young would be given the benefit of NSVJ assistance. The distinctive feature of such care was that resources would be restricted only to those who could be regarded as 'gemeinschaftsfahig' (socially worthy and socially capable) and 'erziehbar', (potentially educable). ${ }^{2}$ Others who were regarded as anti-social in character to an unacceptable degree, according to NSV welfare policies, would not necessarily find that help would be forthcoming from the Party organisation. Those who had shown themselves to be habitual trouble-makers and potentially ineducable, would only be aided insofar as valuable economic resources were not drawn away from the more 'deserving' cases. 3 The NSV was quite unashamed when it proclaimed that it would provide care only for 'worthy' cases. For it firmly believed that:

\begin{abstract}
'the boundless charity of the last fifty years has been concerned with the protection of the chronic sick and the disabled, to the cost of the healthy, and if we seem to employ harsh criteria, it is only in order to make it possible that support for the potential worthiness and capability of countless numbers of socially worthy persons be made available for in the past nothing was left over for these deserving cases.
\end{abstract}

1. HA, 13/259, 'Reichsrichtlinien' p.l. 'Die dabei notwendigen Massnahmen werden in Rahmen der nationalsozialistischen Familienhilfe durchgefuhrt als Ergänzung der naturlichen Erziehungsfaktoren Familie, Hitler-Jugend und Schule'.

2. Ibid., pp.1-4.

3. BA, NS 37ii/1001, fol. 2, 'Das Wesen' see,'Die Aufgabe der NSV'. 'Wir verteilen keine Almosen', pp. 2-3.

4. Reher, Social Welfare in Germany, see pp.1-12. 
Juvenile care of the Party organisation provided assistance for juvenile welfare cases coming from low-income and other families who showed a certain forthrightness and ability to surmount financial and other problems. Juveniles from such families would be given access to all NSVJ resources if their families were, in addition, 'politically reliable' and of 'Aryan' stock. Poverty was not regarded by the NSV as a 'social problem' as such, but as something to be alleviated through Party welfare if possible; it would remain however as a hard fact of economic life within the Third Reich for many working $\neg$ class people. Such lower income families who needed extra welfare assistance from the NSV, either in the form of free holidays for mothers and their small children, or other help in kind from WHW and MuK, were certainly not regarded as 'feckless' because of that. Given that the government wished to continue to pursue a low wages policy no opprobrium would attach to wage-earners whose income was below an adequate level. ${ }^{l}$ The value of the NSV and its various sections for the Nazi government, now including juvenile care, rested upon the organisation's ability to meet some of the problems which arose out of the government's own economic policies. Poor, but socially 'worthy' families would be given help from all the sections of the NSV including juvenile care. The family of a juvenile under Schutzaufsicht (protective supervision) would be allowed every help from the NSV social workers who would, to some extent, treat the family unit as a whole by offering advice to the parents and supporting them in the attempt to 'improve' the behaviour of their offspring. ${ }^{2}$ To understand the NSV interpretation of the
1. Ibid.
2. Ibid. 
socially 'worthy' category, it is necessary to look at the 'asocial' label to see how the use of this, and also the 'potentially educable' one, was part of the NSV's tendency to label cases of need according to its own pre-selected list of social 'acceptability'. But these had little, if indeed any, basis in a well-thought out (or well argued) consideration of moral, ethical and social conduct

to serve as a model for the citizens of the 'new' nation. Far from being attached to a firmly based conception of existing values, criteria which attached to 'acceptability' or 'educability', were utterly debased by being conceived as mere devices to foster the political aims of the new leadership. ${ }^{1}$ While it would be incorrect to say that Nazi values and those of the lower-middle and middle-class were mutually anti pathetic - for clearly they were not - it is true to say that the liberal emphasis of earlier charity based ideas of social welfare had slipped out of the grasp of the Nazi view of charitable conduct and thereby out of the reach of the design of the measures of the NSV itself. ${ }^{2}$ That the staff of the NSV perhaps did not fully understand such criteria of 'acceptability' is not surprising; that the officials of the state also did not was perhaps predictable, given the need of state officials to conform to certain modes of procedure which are capable of being administered. ${ }^{3}$ The various criteria of the NSV, especially in the measures designed

1. Reher, Social Welfare, see Introduction by Hilgenfeldt, 'Our most important and difficult task is to re-educate'.

2. BA, NSD 30.75, NSV. Propaganda-Dienst, November 1944.

3. BA, R36/1001, report from DGT to RMdI, 'Zusammenarbeit zwischen offentlicher und freier Wohlfahrtspflege', 27 th July 1938. 
for the care and protection of the young were not only difficult to fully understand (most notably that of 'potentially educable'), but virtually impossible to administer. ${ }^{l}$ State officials certainly seemed to find this to be true, even though they themselves were having to administer welfare payments in relation to the concept of the 'asocial' category. That these categories of 'worthy', 'educable' and 'racially valuable' were being put to use in the system of child and youth care was to their greater discredit. In order to look at the petty and ill-thought out ideas which lay at the base of some of the selective procedures of NSV administration, one must examine the various articles and guidelines for staff which were circulated internally, and distributed by head-office in Berlin. 2

In one of these internal information pieces of 1936, an example of socially 'worthy' behaviour was outlined, no doubt to clarify to NSV voluntary workers how choices between claimants were made. ${ }^{3}$ A short description of two hypothetical families was given whose income and living standard were exactly the same, but, importantly, where there was no question of 'political unreliability' or any other serious barrier to receiving NSV aid. It was explained why assistance would be given to one family, but not the other. In the first case, the NSV voluntary worker had come upon a disorganised household with neglected children who were being forced to live in dirty conditions, clearly showing signs of parental neglect. Surely this was a prime example where a social worker might offer help and

1. BA, R36/1996, see correspondence between leading Prussian officials of the FUrsorgeerziehungsbeh brde, August/September 1941 .

2. BA, NS 37ii/1001, Fol.2, 'Das Wesen'.

3. Ibid. 
advice. However, it was just this type of behaviour which showed problems of perhaps an intractable nature, which the NSV advised its staff to 'reject'. The reason for this decision lay in the degree of 'fecklessness' which was being exhibited so obviously by the family under scrutiny. Indeed such a family was considered to be, if not 'asocial', for that was a more serious label carrying with it many penalties within the Nazi state, then definitely 'unworthy' by virtue of the degree of serious disorganisstion which it had shown to the NSV social worker. ${ }^{1}$ Indeed, 'worthiness' as described by the NSV often looked like the ability to get on entirely without any help at all from Party welfare workers. An example of a 'deserving' case was the one which, in spite of exactly the same economic difficulties, ran an organised and tidy home, in which clean though poorly dressed children were properly looked after. The article drove home the message by asking the question, 'which of these two families should we (the NSV) help? Answer, the second!'. ${ }^{2}$ In the article, however, it was admitted that the most obvious social need lay with the first example, and it freely declared that the more traditional charitable agencies would definitely favour family number one: but the NSV and the NSVJ were not 'charitable' agencies. In the cause of efficiency and economy, but also on the basis of a new perception of the nature of social welfare, the NSV stressed how utterly essential it was that the more obviously 'worthy' cases should be given help first so that they would not suffer for the sake of those who were, patently, the more hopeless cases. ${ }^{3}$

1. Ibid.

2. Ibid.

3. Ibid. 
The 'asocial' category, if it was applied, allowed the NSV to exclude individuals from the various honours which were given by both the Party and the NSV. No family who had been in serious conflict with the law, or who had tried to burden the welfare services unduly or who had been seen to be financially incapable of managing by being 'feckless' - for example by using the money received from the child benefit schemes for useless luxuries rather than for essential items for the family-would receive any consideration from the NSV. ${ }^{l}$ Honours such as the Mother's Cross would not be given, and benefits such as free holidays would be withdrawn, indeed a family would find that Winter Aid might only be given if extreme poverty could be shown which would result in any children going without. ${ }^{2}$ Such 'feckless' parents would be liable to a certain amount of harassment from local NSVJ staff, especially if there were very young children in the family. They would set about 'looking out' for instances of child neglect. Should that be shown to be the case then the family would be contacted and included in the remedial section of the Jugendamt. Of the various measures which might be applied, the most likely one, in this case, was 'Schutzaufsicht'. 3 The NSVJ would only continue to make contact with such an 'asocial' set of parents if the children were potentially 'educable' or 'biologically worthy' - only then would

1. BA, NSD 30/11, Informationsdienst March 1939, see section III, list of 'asocial' categories in 'Merkblatt fur die Auslese der Mütter, die fur Verleihung des Ehrenkreuzes, der deutschen Mutter vorgeschlagen werden sollen', p.104.

2. Ibid.

3. Ibid., see also 'Jugendhilfe fur Kinder aus politisch unzuverlässigen familien', p.168. 
their own facilities be made available. Otherwise the state provisions only would come into operation, even though in many cases the NSVJ might be the referring agent in the first place. ${ }^{l}$ These harsh policies were readily admitted to be uncharitable, but by pursuing a ruthlessly hard line, the Party agency would 'protect' those who came 'first'. Such a policy, with its Social Darwinist overtones, would be systematically followed through in all Party welfare care. Once the criterion of 'worthiness' had been established, it became virtually impossible for the NSV to include, except on a last resort basis (if economic resources allowed), those who certainly according to most criteria would be regarded as having a genuine and urgent need of social work assistance. Neither is it difficult to see how arbitrary the labelling of claimants into 'worthy', 'unworthy' and 'asocial' cases must have been. The officials of the state welfare offices were not slow to see this, and many other problems of both a conceptual and a practical nature which the NSV had allowed to come into its social welfare policies. Given its independent status, harsh policies could be pursued without the NSVJ coming into difficulty with legal requirements to provide juvenile care. Not surprisingly, state officials resented the manner in which NSV officials could include, or reject, welfare cases according to their very own strict rules and regulations. ${ }^{2}$ None of these were illegal of course, but being strictly applied especially in respect of the 'biologically' unhealthy category, in the opinion

1. Ibid.

2. $B A, R 36 / 1418$, Wohlfahrtsverwaltung, Jugendamt Stettin to DGT, 'Besprechung uber die Zusammenarbeit der Jugendämter mit der NSV', 18th November 1938. 
of staunch Nazi state officials, such as Fiehler of the DGT, they greatly complicated the work of state social welfare. Much extra work and trouble was given to state officials who had to shoulder the burden of excluded cases from the NSV. ${ }^{l}$ State officials seemed to be entirely sceptical of a rigid set of rules which moreover, they had no time themselves to put into force. While the Jugendamter kept to racial guidelines regarding 'Aryan' descent, or applied the 'asocial' category when it was required, ${ }^{2}$ the very narrow distinctions of the 'biologically worthy' ones $N$ the were not favoured by state youth welfare officials, and they showed themselves to be impatient of NSV nit-picking in this area. ${ }^{3}$ Nor were state officials able, or willing, to make such fine distinctions as they themselves pointed out, but neither were they legally required to do so. Moreover, such work would have been hopelessly time-consuming and impossible to administer in a regular manner throughout all the Jugendumter in Germany. ${ }^{4}$ One gains an impression that state officials strongly disliked the NSV's tendency to extend the 'unworthy' categories, which may have been regarded as expanding the 'asocial' designation beyond 'reasonable' limits. Clearly, they felt, it would be difficult, if not impossible, to carry on with the work of youth care if they too were required to use the fine

1. Ibid., the 'splitting' of responsibilities between NSVJ and the state provisions would only result in extra work.

2. BA, R36/1996, Dr. Schow to DGT, 12th August 1941.

3. Ibid.

4. Ibid. 
distinctions of the NSV's 'potentially educable' label in an assessment of welfare cases. ${ }^{1}$

The depth of irritation which was aroused by NSV policies on this matter was made very clear in 1941, during discussions of NSV proposals to be involved to a greater degree in correctional education in Prussia. ${ }^{2}$ Many worries were expressed on the part of the leading officials of the Prussian FE boards over the lack of any clear guidelines for particular methods of choice of 'suitable' cases for the NSV. These, in the main, seemed to be not only ineffective but beyond the ability of long experienced state welfare officials to follow. The issue under discussion was the one of the exclusion of 'unworthy', 'ineducable' and 'biologically unworthy' categories from NSVJ homes. Interestingly enough the Prussian FUrsorgeerziehungsbehurde unanimously questioned such policies, not so much on the basis of their inherent wickedness, but on the less emotive one of sheer ineffectiveness. ${ }^{3}$ Both in practice and in conception these policies, it was felt, were too rigid. This is not to say that Nazi policies on the question of the 'racially valuable' had also been rejected, but that it was privately admitted that the NSV's policies with regard to correctional education, at least, would prove to be

1. Ibid., as one report puts it, 'That the distinctions (between Gemeinschaftsfahig-unfahig) cannot be carried out is shown by figures in Prussia where in a four year activity in the work of $\mathrm{FE}$ in which 6,000 cases have been taken up, only 25 of these have been accommodated in an NSV Home'. This exceedingly low figure refers only to cases 'in treatment' rather than those FE cases being taken up after an initial spell in non-NSV Homes; i.e. in 'nachgehender Fursorge'. See report of the 9th September 1941, p.7.

2. Ibid., p.1-16.

3. Ibid. 
unworkable. ${ }^{1}$

It was agreed, in the form of not very strong hope, at the conference of the Prussian FE Boards, that Party welfare should restrict itself to social welfare activities with less 'difficult' clients such as mothers and children, or with other preventive measures which the NSV had taken over and in which they had (to some extent) gained a monopoly and this included Familienfursorge. In this and other less 'complicated' welfare measures, the Prussian officials showed themselves to be pleased to delegate to the NSV. To some extent they believed that such measures had been shown to be really effective and were to be greeted warmly - especially in time of war. However, during 1941, most importantly, the NSV with an eye on the wider field of $\underline{F E}$ and its administration in Prussia had failed to persuade experts in juvenile care that there was a possibility of making a really worthwhile contribution to the whole question of institutional, correctional education. Apart from jurisdictional problems which arose at the time, the really harsh, selective policies of NSV child and youth care alienated the support of the Prussian Boardsfor an increased level of NSVJ case work in this area. $^{2}$ One senior official at least seemed to be shaken by NSVJ policies and declared them to be 'absurd' for the purposes of correctional education. This issue would be taken up again in 1943 but this will be further examined in Chapter Seven. At this point the question must arise, why, or for what reasons, were these

1. Ibid., p.7. It was also believed that only a small section of cases would be taken up by the NSV, those who were considered to be 'erziehbar', in other words, who showed to the NSV definite 'proof' of educability.

2. Ibid. 
policies so inflexible - for so they were regarded by state officials in Prussia and elsewhere. ${ }^{l}$ When experienced state welfare officials, who were Nazi supporters and Party members, regarded NSV policies often enough as unworkable, why did such rigidity exist in NSV/NSVJ policies even when the problem of caring for the more serious juvenile welfare cases came to the fore? These and other related issues may be answered in two ways, firstly, by saying that in conception, Party welfare was extremely abstract, viewing individual welfare cases in ways not customary for an organisation supposedly designed to help the needy. A ruthless determination to foster certain social values which revolved around the concept of 'community' lay at the base of NSV philosophy, but the collection of at times unrelated ideas - rather than the construction of a philosophical framework - sought to relate these to particular 'duties' existing within the framework of the political aims of the regime itself. Secondly, Party welfare sought a new theoretical base, wishing to find a new frame of reference which would be relevant to and intimately connected with the idea of Volksgemeinschaft. Welfare which was carried out within the Volksgemeinschaft would have to allow for the claims of that entity if it was to remain ideologically 'true' to Nazi goals, both in conception and in practice. Welfare policies which supported individual Volksgenossen would have to make first reference to the whole community before its individual parts if, that is, they were to remain logically fixed within their own set of ideals, however opaque

1. Ibid., 'The 'Gemeinschaftsfahigkeit' of juveniles cannot be decided before the entry to $\mathrm{FE}$ it can only be decided after lengthy observation under medical and pedagogical supervision'. BA, NS 37ii/1001, 'Das Wesen', Fol. 2, pp.1-6. 
they undoubtedly were. ${ }^{1}$

There existed a distorted comprehension in NSV ideas (and in Nazi ideals) regarding the nature of hard effort and the need to develop a sense of 'self-help'. The NSV perspective stressed that 'pitiless' goals were the ones for which the newly 'strengthened' nation would continuously have to strive. But these themselves were conceived out of a whole range of cloudy, emotional outpourings which attached to the claims of devotion to a charismatic Leader. The idea of a 'pitiless' charity, located as it was in Nazi aims, was part also of the NSV's deep and abiding interest in the moulding of social attitudes regarding 'duty' and 'self-reliance'. 2 As they themselves were to say, 'our welfare has nothing to do with charity'. ${ }^{3}$ But a contradiction had crept into such ideas as they were transmitted through propaganda, and this could only serve to obscure the call to the Volksgenossen to put behind them their own selfish interests and concerns. The determination to foster these, and other related ideas, all came within the framework of a call to 'stengthen' the nation. This allowed a serious misunderstanding of the nature of charity and charitable behaviour to emerge, not only in the writings but in the practices of NSV welfare itself. ${ }^{4}$

Given the need, and the desire, to relocate certain traditional values of cooperative activity within the still unrealised

1. Althaus, 'Soziale Eingliederung', see 'Die sozialen Prophylaxe', in A Contribution/III International Conference, pp.10-14.

2. Reher, Social Welfare, pp.1-12.

3. Ibid.

4. BA, NSD 30/11, Informationsdienst, July 1939, see section, 'Aus der Erziehungsarbeit der NSV-Jugendhilfe', pp.168-173; see also 'NSV Jugendhilfe-Allgemeines', p.174. 
Volksgemeinschaft, this was not surprising. Such values would have to be detached from their traditional base - from their roots in the working-class and be transferred into the new social entity which was still in the process of creation, for the Volksgemeinschaft still had to emerge. This is not to say that cooperative values (or goals) were unknown among the lower-middle or middle classes, but that such social behaviour according to some sociologists, at least, describec more closely the social patterns prevailing within working-class life ${ }^{l}$. These values would, in the Nazi Volksgemeinschaft, be 'tacked on' as it were to the individualistic emphasis on 'self-help' (or even self-improvement) which characterised lower-middle class patterns of behaviour. Given the intention to foster such a development, but as a manipulative measure entirely, it was bound to fail so that the unified, people's community would never emerge. ${ }^{2}$ That this complicated task would have to be undertaken also by the propaganda of the NSV is clear, for this emphasis exists in every measure in one form or another. Given that the nation would be urged from 1933 to 'discover' the cooperative values through the medium of the self-regarding ones of self-help and individual effort, a serious distortion of the nature of charitable activity would also take place. This, in turn, would lead to a perverse variant of the Nazi slogan, 'the common interest before that of the individual' emerging in NSV policies as, 'self-help before charity'. That self-help might not logically be equated with 'common interest' (even though it might be with 'strength', or Nazis first, the rest last), would lead to a markedly cruel emphasis upon the need to exclude everyone who

1. John H. Goldthorpe et al, The Affluent Worker in the Class Structure, Cambridge 1971, p.13.

2. Alternatively, the cooperative values describe social patterns in traditional communities, see R.A. Nisbet, The Sociological Tradition, London 1970, pp.47-107. 
might be seen to endanger the interests of the larger group. These contradictions would exist in the welfare policies of the NSV and in the selection procedures of cases for treatment in the NSV section devoted to juvenile care.

A flat and repetitive tone suffused the attempts in NSV writings to deal with ideas such as the relative unimportance of individual need. But this was not a stylistic fault entirely, for it was part of the related inability to formulate a more complicated set of ideas than the ones which had existed during the 'time of struggle', and which were relevant to that time alone. The impossibility of transferring these into the value system of a sophisticated society led to serious and cruel inconsistencies flowing into the welfare system itself. ${ }^{l}$ Where charity as dispensed by Nazis had once been a matter for a small in-group protecting itself in a hostile environment, it now became something which would be transformed into an ideological issue; one of 'care' exclusively directed towards the 'community'. Individual need would simply disappear from the picture.

Perhaps the results of all this mistaken effort to relocate the values of 'community' and 'cooperation' within a mythical social entity were seen most clearly during the war. The failure of these attempts has been outlined in a recent study of werttemberg where, under pressure from war-time rationing, the more familiar self-seeking (not necessarily selfish) attitudes came to the fore once again - had they ever been replaced? Long-held traditional values and practices came to the surface once more; indeed,

1. Hilgenfeldt, Idee; see also outline of NSV training courses, see 'Stoffplan-Kindergärtnerinnen', NS 37ii/1031, n.d. 
self-help as it might normally be interpreted, came to spoil the war effort through the unwillingness of the population to conform with the rules and regulations of war-time rationing. The war effort was thereby seriously affected by such a lack of willingness either to participate in the cooperative values of Volksgemeinschaft, or to give in to pressure from the regime itself. ${ }^{l}$ The long-term aims of the NSV would ensure an adherence to a rigidly held view of a non-charity based, harsh provision of welfare which would also be applied in its youth welfare section. The many difficulties which this caused would only lead to the questioning of NSV policies by leading state officials who themselves could only wonder at times about the real worth of such policies given their inherent weaknesses. $^{2}$

Regardless of the more traditional practices of social welfare, and even regardless of individual need, help would be dispensed by the NSV when such help was properly located within its own ideological base, and nowhere else. Even if that particular base did not necessarily relate to the practice of welfare care and went against the intentions of state officials, it would not be disregarded. And such seems to have been the case, for there was no indication that Hilgenfeldt would alter any of the more fundamental NSV ideas regarding care for those in need to suit the needs of certain substantive areas of the social welfare system. The absurdity of preferring certain 'acceptable' modes of behaviour over

1. Jill Stephenson, 'War and Society in WUrttemberg, 1939-1945: Beating the System', German Studies Review, February 1985, pp.89-105.

2. BA, R36/1996, Dr. Schow to DGT, 12th August 1941. 
others in an assessment of children under observation for the placement of $\underline{F E}$, and looking for behaviour, or physical attribute, which virtually exempted them in the first place from needing such care, hardly needs emphasising, as state officials in private at the time were able to point out. Nor was it believed that in the complicated and difficult work of correctional education, the honorary helpers of the NSVJ could contribute much of value. It was feared that they simply had neither experience nor training for such work to which they had brought only their own limited, personal experiences of family life. ${ }^{1}$

Nevertheless, in spite of the hostile stance of some state officials, the NSV endeavoured to simultaneously carry through an 'educational' function as well as a welfare one within their youth care measures. Indeed the NSV and the NSVJ continually stressed how important the role of 'educator' was. Within youth welfare especially, the lesson which they wished to drive home was not only the development of the spirit of 'self help' (either in individuals or within the family unit), but the awakening of a sense of civic responsibility in the hearts and minds of the young. It was these two virtues which would supply the corner-stone of the new 'strength' of the people. ${ }^{2}$ The very substance of the NSV's youth welfare measures, supported as it was by an altogether abstract conception of the role of the 'worthy' citizen, would not alter significantly and it would continue to reject the more 'charitable' characteristics of the Weimar period. By excluding entirely from NSV youth welfare the

1. Ibid., 'Die ehrenamtlichen Helfer der NSV sind fur die Mitwirkung in der FE nicht geeignet, weil sie lediglich die Erfahrungen aus ihrer eigenen Familie mitbringen und gar nicht wissen oder nicht wissen konnen, was sie mit 'verbogenen' Kindern anfangen sollen', see report of 9th September 1941.

2. Hilgenfeldt, Idee. 
idea of charitable aid for those in need, it became easier to reject those who were not only socially or politically 'unacceptable' in NSV terms, but those who were 'biologically unhealthy' as well. ${ }^{l}$ As instructions to the Landesjugendamt der Rheinprovinz in 1934, outlined,

'it should be remembered that in the co-operative work of the state youth welfare office, the church agencies and the NSVJ, as far as the latter is concerned, only the 'biologically healthy' will be allowed to make use of the resources of the NSVJ'.

As one official of the NSV put it,

'It is to be remembered that as the religious agencies place the charitable nature of their work at the forefront of all welfare measures, it will be to them, and not the NSVJ, that the care of the 'asocial' and the 'hereditarily sick' will be assigned.'

DGT fears that the NSVJ would eventually leave the burden of caring for the physically disabled, and others coming within the NSV rejected categories, not only to the churches, but to the state agency as well, were quite justified.

The institutional and other care which was organised by the NSVJ placed a high degree of emphasis upon re-training and re-educating those in their care. The numbers of those being cared for under NSVJ Schutzaufsicht or protective supervision in 1936 were 15,587 , and this figure would rise to 28,478 in 1937. Altogether

1. While this was not a logical step, once the process of 'exclusion' of certain categories got underway it encouraged a tendency to reject all potentially 'useless' individuals; see BA, NS 37ii/1001, fol. 2, 'Das Wesen', pp.2-4.

2. HA, $13 / 259$, 'Zusammenarbeit mit der freien Wohlfahrtspflege', report of December 1935.

3. Reher, Social Welfare, see pp.1-12. BA NSD 30/11, Informationsdienst, March 1939, 'Bev8lkerungspolitik, Erb-und Rassenpfege', pp.99-104. 
between 1936 and 1938, 72,861 juveniles were delegated from the Jugendamt and came under NSVJ 'protective supervision'. Young people in this category had been held to be in danger of total moral neglect, or to be committing petty crimes: either case resulted in Schutzaufsicht being applied through the Jugendamter, but did not necessarily result in the person's being placed within institutional care. Fursorgeerziehung on the other hand usually resulted in the removal of the juvenile from the influence of the family home. Between 1936 and 1938, 45,973 cases, mainly of the non-institutional variety it seems, were 'transferred' to NSVJ care and a much smaller number of cases altogether were taken into institutional care in the existing NSV-Jugendheimstatten of which 40 existed at the end of $1938 .^{1}$ These homes provided 2,547 available beds for such cases. $^{2}$ FE under the Nazis seems not to have followed a uniform pattern within state institutions and Homes, with some using very harsh regimentation, while others followed a more 'enlightened' regime to instil the values of self-reliance and self-discipline. ${ }^{3}$ However, the former example, that of strict regimentation, seems mainly to have become more apparent during the war and no doubt the NSVJ too employed a strict regime which had, increasingly, fewer members of staff to deal with 're-education'. ${ }^{4}$ The conditions in NSVJ institutions under which young people had spent some time, were supposed to encourage a useful return into the Volksgemeinschaft. 5

1. Ibid., July 1939, p.177.

2. Ibid.

3. Basic and Zonal Handbook, 'Youth Welfare', p.16.

4. Ibid.

5. HA, 13/259, 'Reichsrichtlinien', pp.1-19. 
A typical NSVJ Home before the war accommodated between 30 and 40 juveniles, and was designed to take on the character of a large family community. ${ }^{1}$ During a stay in one of these the youth would be expected to attend both school and the local HJ. Normally he would be expected to remain in institutional care for a period of a few months only, up to the maximum of one year, for the NSVJ was mindful of avoiding the consequences which might follow from a longish stay in an institutional environment. As the NSVJ itself put it, to avoid, 'an estrangement from the requirements of practical life'. ${ }^{2}$ Even though NSVJ officials could show themselves to be 'enlightened', in this respect, they were less concerned about the individual juveniles than with a desire to avoid rendering those who had spent a long period in a Home under the provisions of $\underline{F E}$, and other measures, incapable of leading a useful life once a return to the normal conditions of social life had been made. ${ }^{3}$ The NSVJ were usually careful about ensuring, as far as they could, that no extra burden on the community would be created by their own particular social work measures. ${ }^{4}$ However, it is difficult to say how far they were successful in this respect; no doubt the desire to save money may have served as an extra encouragement to shorten the length of an average stay. ${ }^{5}$ The percentage of delegated cases of $\underline{F E}$, as opposed to other NSVJ care in 1938, was 4.2\%, and non-institutional care,

1. Ibid.

2. Ibid.

3. Ibid., see also 'Zusammenstellung', pp.1-7.

4. Ibid.

5. Ibid., 'Reichsrichtlinien', pp.1-19. 
such as welfare advice to juveniles, came to $16.6 \% .^{1}$ In other words the use of $\underline{F E}$ was not significantly greater than other measures but this was due mainly to difficulties in co-operating with the Jugendamt, and in the nature of NSVJ care itself which stressed Vorsorge not FUrsorge; Schutzaufsicht or protective supervision came to $5.9 \%$ of the total amount of cases in $1938 .^{2}$ By 1938 , the total number of youth welfare cases of the NSVJ throughout the Reich came to 441,144 and was seen to average between 35,500 and 40,000 cases per month during the year. ${ }^{3}$

1. BA, NSD 30/11, Informationsdienst July 1939, p.178.; see also $B A$, NS 25/1233, 'Entwurf' RMdI, January 1941.

2. BA, NSD 30/11, Informationsdienst July 1939, p.178.

3. Ibid., p.179. 
for Youth Care

The existence of organised Party welfare from 1934, as state officials were soon to be aware, could only serve to create significant alterations (for the state agency) within the delicately balanced structure of private and state welfare. ${ }^{l}$ The system of youth welfare had not been designed to accommodate a non-state agency which sought not only to dominate the private agencies, but the state sphere as well. From 1937 it was to prove that these issues would increasingly come to the fore. Until an effective clarification of the existing laws over the relationship between NSVJ and state officials was provided, or until a policy with regard to the role of the private agencies was worked out between the Party and leading Nazi officials in Berlin and Munich, then juvenile welfare would remain a potential battle-field upon which the ambitious claims of the protaganists of Party and state would be fought out. ${ }^{2}$ Inevitably, youth welfare would become an area where a bitter struggle for power would come to vitiate those measures which were intended to provide care and protection for the young. Issues such as adoption procedures especially, and the provision of institutional care would soon become jurisdictional, not welfare matters per se. ${ }^{3}$ Leading Party and state officials would be pulled into the continually emerging arguments over the balance of the

1. BA, R36/1001, see correspondence of 1938 .

2. Ibid., discussion document 'Zusammenarbeit zwischen 'offentlicher und Freier Wohlfahrtspflege', 1938.

4. BA, R36/1996, 'Aufzeichnungen Uber die Besprechung zwischen Vertretern preussischer Fursorgeerziebungsbeh brden', 9th September 1941, report on proposed NSVJ participation in correctional education. 
various youth welfare provisions. In any matter which concerned state over Party control, Frick would be prepared only to support the claims of powerful officials such as Muthesius of the RMdI and others. On the other hand, Hess and Bormann were prepared to give support to NSV claims, though not unreservedly. Such disputes would emerge as a common occurrence and would involve Frick, Bormann, Hess, Fiehler, Hilgenfeldt and RMdI personnel in time-consuming and, often enough, fruitless discussion. ${ }^{l}$ According to the opinions of several of the leading state and Party officials of both the DGT and the department for Kommunalpolitik, the NSVJ was determined to achieve the fullest participation in youth welfare, but it also showed itself to be desirous of achieving a supremacy over all youth care, as well as other state welfare arrangements such as the provision of public assistance (Bffentliche FUrsorge). ${ }^{2}$ While the NSV would remain unsuccessful in the latter case because of a strong defence by state officials in 1939, it seemed likely that the NSVJ would eventually gain its wishes, if not sooner, then later. But the state system of juvenile welfare would not easily succumb to pressure, since senior staff of the Jugendumter had no intention of allowing the NSV to disrupt, and then take over, the responsibilities of the officials of the state without a real struggle. ${ }^{3}$

The issue of the balance between state and non-state facilities for social welfare which had arisen in the last years of the Weimar

1. BA, R36/1001/2/3;962/964/974; 1418; 1996. Correspondence between Hilgenfeldt and leading state officials can be found in the files of the DGT and the department for Kommunalpolitik: the files of the NSV such as NS $37 i i$ are not so useful, for this only contains much routine correspondence.

2. $B A, R 36 / 1002$, see correspondence of $1938 / 39$.

3. Ibid. 
Republic, emerged again and was subjected during the Nazi period to the impact of an increasing number of dilemmas. Between 1935 and 1939, these would generate a massive correspondence going between NSV, DGT, RMdI and the state Jugendamter senior staff, with numerous study papers also being produced by state and Party officials. In addition, the NSV would be unable to produce such interesting material as its opponents who were keenly motivated at this time to make a spirited defence of their own facilities. ${ }^{l}$ The contribution of the NSV seems to have been restricted mainly to the production of the draft for a new law in January 1934, so that such considerations had been in mind,this time. The NSV would, of course, take over the Arbeitsgemeinschaft der freien Wohlfahrt later in the year and the draft proposals were drawn up under NSV direction. These proposals outlined the responsibilities of state, church and the 'Kraft der Volksgemeinschaft', all of whom - though no doubt not equally - would have the task of supporting and protecting German youth. ${ }^{2}$ It is clear that the NSV had already realised that if it were to obtain a significant share of the work of the state welfare system, then it must do so under conditions which would, at first, relate to the existing legal arrangements. But it seems that this attempt to draw up a new law and discard the one which had been designed with a strong state participation in mind, would come to nothing. But this would not work against the NSVJ, on the contrary, for the law was designed with the protection of non-state agencies in mind and could

1. BA, R36/1002, see report of meeting between NSV and DGT officials in Berlin, 27th February 1939.

2. $H A, 13 / 259$, Reichsgemeinschaft der freien Wohlfahrtspflege Deutschland, 'Entwurf eines Reichjugendgesetzes', 3rd January 1934. 
only work in favour of the frei NSVJ. The democratically conceived law of 1922 worked in favour of the expansionist claims of the NSV and, frequently enough, entirely at the expense of the state arrangements. Thus it would be fiehler of the DGT who would consider that a new law should be drawn up after the war, not, as far as can be discovered, Hilgenfeldt. ${ }^{l}$ Nevertheless, it does seem that a strong non-state system had existed in minds other than Hilgenfeldt's for in Prussia in 1933 it looked as though non-state facilities would be given strong support. But this seems only to have been an uncharacteristic aberration of Goering, who had been interested at that time in this idea. ${ }^{2}$ However, such moves to reduce the state's role were only to mis-read the future direction of the regime; they were to miss the mark entirely. From the time of the creation of the Deutscher Gemeindetag in 1933, there existed little real possibility that the participation of the state would diminish. ${ }^{3}$

Juvenile care failed therefore to offer the scope, or the opportunity, for an ambitious early Party domination of the welfare system. The youth care of the Party had entered into a sphere where others had long been active. Not only the state, but also the churches would be unwilling to relinquish their own participation in the juvenile care system in favour of the new Party organisation. It was one thing rapidly to build up the NSV's 'Winter Aid' through

1. BA, NS 25/1270, 'Jugendhilfe im Rahmen der Gemeindlichen Selbstverwaltung', speech to the Hitler Youth given by Fiehler, n.d. (?1943).

2. Friedlander and Myers, Child Welfare in Germany, pp.20-21.

3. BA, NS25/124, Fol.1, VB, 'Der Auftakt der Kommunalpolitische Schulungswoche', 5th December 1933. 
the auspices of the Propaganda Ministry, thereby creating a huge welfare scheme which would remain entirely a matter for the NSV, but quite another to make a premature bid to take control over the whole system of juvenile welfare care in Germany. But this is not to underestimate the influence of the NSV and its new youth welfare facility. It gained significant victories, one of these being the ability to make strong and successful representations when it looked as though NSV subsidies were coming under fire from officials who where trying to reduce expenses, as well as perhaps, trying to limit the scope of the Party organisation. ${ }^{l}$

Of the various documents which were devoted to an examination of this situation, perhaps the most sensitive of these came from the office of the department for Kommunalpolitik. It was written by neither an NSV, nor a state welfare official, but by someone who was concerned to examine the whole question from the point of view of the Gemeinde, or local government and local community arrangements. ${ }^{2}$ It was explained how welcome the new participation of the NSV had been, at least at the beginning. This had been welcomed on the basis of the need for extra help, however good relations between NSVJ and local government staff had become erroded entirely by the actions of the NSV, certainly by the beginning of the war. ${ }^{3}$ More in sorrow than in anger it seems, the document set out the serious problems which had affected the whole area of social welfare, not only youth care itself. The DGT had realised in 1939 that a major part of the

1. BA, R36/962, Hilgenfeldt to Dr. Lippert, letter of 7 th December 1936; see Chapter Two, p.69.

2. BA, NS25/1162, 'Gemeinden und NS-Volkswohlfahrt', p.2.

3. Ibid., pp.1-24. 
'attack' coming from the NSV over the question of the administration of public assistance rested upon two serious accusations. Firstly, that state social welfare was 'too bureaucratic' in form and organisation, with no interest being shown in the importance of the need to reduce staffing levels. Secondly, and more seriously perhaps, was the suggestion that the material substance of all state welfare belonged within the previous era, and its perceptions were 'rooted' in the liberalistic period of the Weimar Republic.' The NSV leadership seriously suggested that state officials were 'excessively' concerned with devotion to fixed norms of procedure and efficiency of operation which themselves interfered with the aims of the Party organisation. This was certainly on target, for it had been necessary, in one serious disagreement between Hilgenfeldt and Spiewock in Berlin over the arrangements for subsidies for pre-school facilities, for Spiewock himself to quote in a letter (and in its entirety) his own oath of allegiance as a state official. This was in order to drive home the point that he was unable to change certain rules of procedure in favour of the NSV, for this would have been entirely illegal. This serious dispute had also involved, indirectly, church provisions and it would be the denominational arrangements which would suffer most in this particular issue which arose during $1938 .^{2}$

These and other problems which arose at the time may only be understood as something which can be described as a 'trivial'

1. BA, R36/1002, 'Entwurf einer Denkschrift zur Frage der Vereinfachung der Offentlichen Fursorge', n.d. (?1938).

2. BA, R36/1001, see Spiewock to Hilgenfeldt, 'Denkschrift' of loth May, and letter of 17 th May 1938. 
expression of an underlying structural problem. Far from being unimportant at the time, and in certain cases of utmost urgency, these issues were nevertheless a sign of something else. Inevitably they were an expression of the fundamental problem which lay at the heart of the disagreements between Hilgenfeldt and state officials. They were undoubtedly an expression and a sign of the troubled relationship between the Party on the one hand and the state on the other, which the regime itself would continue to be unable to solve.

In the system of social welfare however, any set of jurisdictional issues which brought about a quickening of the tempo of the conflicting claims of state and Party, aroused yet again the issue of the unsolvable problem of the structure of the regime itself. ${ }^{1}$ The very existence of the NSVJ, given its long term aims, was a potential irritant within the existing arrangements, for with every foray across the border into the realm of the state's legitimate sphere of influence the NSVJ could only activate a whole set of Party/state problems which were impervious of solution. It was for this reason that in the report 'Gemeindenund NSV' it was stated, perhaps rightly, that the only solution to these jurisdictional and other issues would be for the NSV to reduce its claims by restricting its ambitions; otherwise, it would become a 'Fremdk४rper' within the social welfare system itself and it would only serve to undermine the goals of welfare in general. 2

The realisation (in 1941) that two separate types of juvenile care would emerge if the NSV were allowed to persist in attempts only

1. Caplan, 'The Civil Servant in the Third Reich', see Chapter Seven.

2. BA, NS 25/1162, 'Gemeinden und NS-Volkswohlfahrt', p.2. 
to take on the more hopeful cases was regarded to be not only a misfortune for state youth welfare but for German social welfare as a whole. The sad comment of one senior official that he would, 'lose his best children to the NSVJ', speaks volumes on this particular topic. ${ }^{1}$

By $1935 / 36$ it was clear that the NSV itself had became seriously interested in many areas of the social welfare system, none of which strictly speaking had anything to offer an organisation which was ideologically committed to using honorary staff; public assistance being one example of this. Perhaps the general view coming from local welfare offices reporting that NSV participation had turned into something which was entirely unwelcome, , the direction of the thrust of the NSV from almost the beginning of the war, and this also included the arrangements for youth care. ${ }^{2}$ As the report 'Gemeinden und NSV' asked, when many local state welfare officials were being 'pressed to the wall' by the actions of NSV honorary workers, how, on any level whatsoever, could such practices be described as 'cooperative'? ${ }^{3} \quad$ Nowhere perhaps was the absence of the 'spirit of the Volksgemeinschaft' more apparent than in the correspondence and in the reports of the DGT and the NSV. A simmering enmity which lay beneath the surface at all times, was ready to break out at a moment's notice whenever a new set of proposals was presented by Hilgenfeldt for a greater degree of participation. The state officials carried out their struggle with the Party agency by

1. BA, R36/1996, Dr. Schow to DGT, 12th August 1941.

2. BA, NS25/1162, 'Gemeinden und NS-Volkswohlfahrt' .

3. Ibid. 
carefully circulating copies of letters to every official who needed to know of the latest developments in whichever Runderlass was in process of discussion. ${ }^{1}$ The care with which this was done shows how relatively powerful the NSV was, for it had influential supporters not least of whom were Goebbels and Himmler. ${ }^{2}$ A continuing concern of the state officials, which had emerged during 1935/36, was that the NSV would soon manage to achieve a position of real power and dominance, if this were to happen it could only mean that the state agency would be reduced to operating merely as a funding body for the NSV. ${ }^{3}$ This fate was regarded as being of decisive importance not only for state officials who wished not to lose their own powerful positions, but also for its significance for the question of the relationship between Party and state. Through such developments it was feared that Hilgenfeldt would be transformed into a 'sort of commissar for social welfare'. ${ }^{4}$ The relations between the two agencies were increasingly fraught with problems; officials of both Party and state agencies showed how unwelcome the proposals for either a greater (or a lesser) degree of participation were. Neither party wished to give way in any jurisdictional issue and for this reason discussions over new proposals were usually unsuccessful. One victory at least could be seen to have been gained in 1939 by the state agency when the leader of the NSV was obliged to state openly,

1. BA, NS 25/1233, 'Vereinbarung zwischen RMdI und Stellvertreter des Fuhrers Uber NSV-Jugendhilfe'. Discussion document from department for Kommunalpolitik.

2. See Erich Hilgenfeldt file, Berlin Document Center.

3. BA, R36/1002, report to DGT, 'Aufzeichnungen Uber den Gedanken einer Ubernahme der Offentlichen FUrsorge durch die NSV'. n.d. (?1939).

4. BA, R36/1002, DGT to Fiehler, letter of 2lst December 1938. 
during discussions in Hess's office, that his intention was not, nor had it ever been, eventually to take over the responsibilities of the state arrangements. ${ }^{1}$ But Hilgenfeldt was quite used to making such statements, not only out loud, but in long letters to state officials who, as far as Spiewock in Berlin was concerned, showed little sign of believing him. ${ }^{2}$ State officials, and especially Spiewock, had every reason to mistrust NSV claims and pronouncements, for they were usually given with some other aim in view. Althaus himself was heard to say that agreements reached could be altered later when the time was ripe to do so. ${ }^{3}$ These and other utterances would shock some state officials who were trying genuinely to reach a workable arrangement with the Party agency. ${ }^{4}$ State officials wished to be kept informed of opinions favourable to an NSVJ dominance of state responsibilities and wanted to be made aware of all such responses which came to notice. ${ }^{5}$ One of these, which is interesting only insofar as it was uncharacteristic of leading Nazi personages to be quite so openly favourable to the NSV, was the one which was reported to have been given by Reichstatthalter Friedrich Hildebrandt who gave voice to the opinion that there existed a certain confusion

1. See Siegel, 'The National Socialist People's Welfare Organisation 1933-39', p.254.

2. BA, R36/262, Spiewock to Stadtprasident Berlin, letter of 20th January 1937.

3. BA, NS $25 / 1162$, from Dr. Stiemle to Dr. Jobst, letter of 9th June 1942.

4. Ibid., see also R36/962, Spiewock to Hilgenfeldt correspondence of 1937; R36/1001, Spiewock to Hilgenfeldt letter of 17th May 1938; NS 25/1162, see 'NSV und Gemeinden' and 'Gemeinden und NS-Volkswohlfahrt', 1942.

5. BA, R36/1001, 'Zusammenarbeit zwischen offentlicher und freier Wohlfahrtspflege', Anlage zu III, 3246/38, 1938. 
with regard to the system of juvenile social welfare. For example as he put it,

I do not understand why so many social welfare organisations exist when the FUhrer has commissioned the NS-Volkswohlfahrt with the social care and support of the Volk. The NS-Volkswohlfahrt with its thousands of diligent workers is in the best position to watch over the welfare activities of the people. A reduction of the divergent nature of all areas of private, communal and administrative welfare can only succeed where it is the party that fulfils the goals of welfare.

This was a sentiment with which the NSV would have happily agreed.

At the end of 1938, the NSVJ was carrying out $37 \%$ of the existing juvenile care in the Altreich, and in the newly annexed Austria, where Party/state problems did not apply, it would rise to as much as $80 \%{ }^{2}$ The NSV's own figures show that the levels of NSVJ participation varied greatly from area to area. This was true for various reasons, one of which was the need to build a good relationship, not always an easy matter, with the local senior state official of the area in question. ${ }^{3}$ In any case Caritas and Innere Mission were still carrying out a significant level of youth care activities in co-operation with the Jugendamter though such levels were dropping through the intention of some state officials to reduce such activity just as soon as it was feasible. ${ }^{4}$ Where shortages of suitable welfare workers existed, the NSV would find that an offer to supply extra helpers was greeted most warmly as in Stettin, where a

1. BA, R36/1002, extract from the Niederdeutscher Beobachter 3lst December 1938.

2. BA, NSD 30/11, Informationsdienst, July 1939, p.179.

3. BA, R36/1418, Jugendamt/Stettin, report to DGT of 18 th October 1938 .

4. $B A, R 36 / 1996$, new regulations and instructions from the Oberprassident Rheinprovinz, Dusseldorf, on NSV participation in 'Familienfursorge', 7th February 1939. 
short while before the setting up of the NSVJ in the area, only one Volkspflegerin had existed in one country Kreis to carry out welfare and health care duties.' In the work of 'outdoor' care, for the carrying out of FE in the Stettin area, the NSVJ would find that such help as it could offer would be happily accepted. It may well be that the provision of much needed auxilliary help was the ideal way in which the NSVJ could begin to make a real contribution to youth welfare in local areas, and begin to participate in a really significant way. An uneven and hard-won distribution of NSVJ participation indicates how problematic this would prove to be, however. In Berlin in 1938, the total number of juveniles under registered NSVJ care came to 16,213 , of these cases 2,783 had been delegated through the Jugendamt, and only 26, and 3 , from Innere Mission and Caritas respectively. ${ }^{2}$ These figures do not include kindergarten or other pre-school provisions. In the city of Berlin, the NSVJ reported that it was carrying out $81.3 \%$ of the existing juvenile care - which seems to be a high figure - however, there was no outline of the precise levels of church and state care included in the NSV figures. ${ }^{3}$ This would mean that the share of denominational youth care in Berlin came to well below $10 \%$ at that time. Such an extremely high percentage of NSVJ participation was not registered in other cities; in DUsseldorf for example the level was $20.1 \%$, but given that this figure represented a total of 49,309 cases altogether, it must be assumed that the NSVJ was operating somewhere

1. BA, R36/1996, Verwaltung des provinzialverbandes Stettin to Frick, on regulations regarding 'Aussenfursorge', 18th July 1939.

2. BA, NSD 30/11, Informationsdienst, July 1939, p.179.

3. Ibid. 
near an optimum level in that city. ${ }^{l}$ The Jugendamt in DUsseldorf had delegated the highest number of juveniles of all the Gaus to the NSVJ during 1938, with a figure of 37,012 cases being referred, so that it must be assumed that the city had a very high level of juvenile welfare cases to deal with at this time, possibly more even than in Berlin or Hamburg. ${ }^{2}$ However, the figures which describe levels of participation do not at the same time reveal the problems and difficulties which lay behind the inclusion of the NSV's youth care section into the juvenile care system." A rich source of information on this issue are both the files of the DGT, and those of the department for Kommunalpolitik. 3

In 1938 a fairly typical draft agreement was presented to the leading officials of the state and the Party agencies for examination, it set out the responsibilities of both and it tried to arrange for new 'delegatory' tasks to be worked out according to Article 11 of the RJWG. Cooperation and participation were intended to be built into these formal agreements between the Jugendamter and the NSV, but NSV officials would continually try to push forward their claims wherever possible and gain as much as they could in every attempt to try to clarify and work out the responsibilities of a welfare agency of independent status according to the provisions of the law. The NSV intention to work strictly within its own guidelines for caring for the 'erbgesunden' and 'gemeinschaftsfyhig'
1. Ibid.
2. Ibid.
3. $B A, R 36 / 1418$; $1001 / 2 / 3$, see also $R 36 / 962 / 4$. 
emerged at this time as a possibly unsolvable problem in the minds of some at least. ${ }^{l}$ It was pointed out by one official who had been asked to comment on the 1938 draft proposal that the NSV's determination to deal only with such categories introduced a serious hindrance into the cooperative character of future welfare work between the two agencies. If the care of 'erbiologische belasteten Kinder' were to be left to the care of the Jugendamter exclusively it would hardly contribute to the development of good relations. ${ }^{2}$ Not only that, but the expertise of the specialist staff of the youth welfare office would be lost to children on the basis of 'NSV care only', indeed such a rule could only be regarded as a source of many future difficulties. However, at the same time it was pointed out that a solution to the problem had been found. Unusually, it may be emphasised, the officials of the state welfare office in one district of Stettin and the Gauamtsleitung of the NSV had undertaken to agree that the NSVJ would take on full responsibility of the work of foster children without the NSV's making use of the 'unworthy' distinction between individual cases. Supervision and control of the foster children would be managed without this category being applied so that all foster cases would be taken up by the NSVJ and unity of treatment would be ensured. ${ }^{3}$ State officials too would undertake not to make visits to families where an NSVJ helper was active so that no

1. BA, R36/1996, Dr. Schow to DGT 12th August 1941. $B A, R 36 / 1421$, 'Untersuchen zur Problematik in der Erziehungsfursorge: Aus der Arbeit der Jugendpsychiatrischen Klinik und dem Landes jugendamt der provinz Oberschlesien'. n.d. (?1943).

2. BA, R36/1418, Jugendamt/Stettin, report to DGT of 18th November 1938, p.2.

3. Ibid. 
interference which would ruin the confidence of those being given care would occur, and unity of treatment procedures would be secured. $^{l}$ However, such a concordance was only achieved out of a real flexibility on the part of the NSV Gauleitung who acknow ldged the predominance of the state's responsibilities in stettin. ${ }^{2}$ The NSV/Stettin agreement ensured an 'insertion' of NSVJ assistance, so that the Oberburgermeister was hopeful at this time that these agreements would only lead to useful participation of NSVJ welfare workers in the area. However in Frankfurt/Oder at exactly the same time, officials were mostly concerned about the existence of the honorary status of the NSVJ helpers and it was a matter, they felt, which the DGT and the Jugendamt should undertake to consider fully for its significance in relation to all youth welfare. ${ }^{3}$ This particular report included the important problem of the 'contradiction' now introduced into the decision making process through the administration of tasks to be delegated to the NSVJ. This, it was added, disturbed the unity of the urtlichen Verwaltung. ${ }^{4}$ All of these problems had to be not only capable of solution, but they had to be solved before any firm guidelines could be put into operation. On the other hand, both in 1938 and 1939, it was demonstrated that where the NSVJ could provide an 'extra pair of hands' it made a valuable contribution to the work of youth welfare. Where it could also prove to be flexible, then this could only

1. Ibid.

2. Ibid.

3. BA, R36/1418, 'Zusammenarbeit der Jugendämter mit der NSV', secret discussion document, 28th October 1938.

4. Ibid. 
increase the valuable help which was given. Such flexibility seems not, however, to have been the norm, for no other reports of such agreements have been found, but at the local level a few such agreements might have been informally concluded so that the NSVJ could co-operate more fully and thereby participate in a meaningful way in juvenile care. However, this conclusion is merely conjectural and until further evidence of such agreements is discovered it must be assumed that the NSVJ would hold to its harsh, and probably unshakable, policy.

Further formal agreements were drawn up in 1939, and they were discussed at that time within the Interior Ministry in order that a decree could be drawn up. This matter had been in hand from 1937 when Hilgenfeldt participated in a meeting organised by him to which state and NSV officials were invited to discuss the legal implications of the delegatory tasks of the NSVJ - to see how these could continue to be taken up. ${ }^{1}$ It is clear that the question of the unsalaried honorary helper which came up at the time, was proving to be one of the more important sticking points in the consideration of Party welfare work. ${ }^{2}$ The numbers of NSVJ staff at the end of 1938 numbered altogether 76,070, and the number of salaried specialists who worked in the Gau and Ort offices came to 4,294. It is clear that the majority of NSVJ social workers were entirely honorary, received no salary and worked on a part-time basis though Gau and

1. BA, R36/974, Hilgenfeldt to DGT, letter of lst October 1937. Ibid., 'Tağsordnung', for meeting on 28th October 1937.

2. $\mathrm{BA}, \mathrm{R} 36 / 1418$, DGT Landesdienstelle Thuringia to DGT, Berlin, 17th September 1938, BA, R36/1996, 'Besprechung/preussischer FE/Uber/NSV', 9th September 1941. 
Kreis full-time staff were salaried. ${ }^{l}$ However, not every opinion of the honorary unpaid social worker was an entirely negative one: the work of preventive welfare, it was put forward in 1941, might just as effectively be carried out by honorary staff as by full-time paid staff. To a large extent the NSVJ was committed to the use of the honorary unpaid worker who undertook to carry out the work of welfare, and much else. ${ }^{2}$ Given the impetus of the need to create the ideal 'sense of service' within the minds and the hearts of the people, the use of honorary helpers had become an ideological matter. To this extent, the NSV had become a prisoner within the philosophical framework of its own policies, for it would find that it could not now withdraw from its own, perhaps now 'dysfunctional', policies either publicly, or in the eyes of the Party in Munich. It had to maintain the semblance of unity of purpose for the sake of the common weal within its organisational arrangements, for the absence of this would have made it likely that the rationale of the NSV might have evaporated entirely by the end of $1938 / 39$ or thereabouts. ${ }^{3}$ Staffing policies were dictated by such considerations though there is little evidence to show that Hilgenfeldt greatly disliked them, even when they were causing him trouble in his bid to arrange for the increased participation of his voluntary staff within the system of

1. BA, NSD 30/11 Informationsdienst, July 1939, p.179.

BA, NS 26/261, 'Aufkommen und Verwendung', p.25.

2. BA, R36/1418, report to DGT from Jugendamt/Stettin letter of 18 th November 1938; BA, R36/1996, Verwaltung des Provinzialverbandes Stettin to Frick, 'Aussenfursorge', 18th July 1939.

3. As state officials put it, why should the NSV be better than the state arrangements, in providing 'National Socialist' welfare; BA, R36/1996, Dr. Schow to DGT, 12th August; see also Fiehler's speech to the HJ in 1943, BA, NS 25/1270. 
youth care. ${ }^{l}$ This enterprise had to succeed of course, for no welfare organisation could leave out of its sphere of activity the support and the care of young people.

State officials may have begun to realise as early as $1938 / 39$ however that the NSV was heading into serious difficulty with regard to its policies which were proving to be a hindrance to NSVJ efficiency and, worse, its ambitions - because of the growing reluctance of state officials to make arrangements for NSV participation in the Jugendamter. ${ }^{2}$ For it had now to suffer criticisms not only of the inefficiency of its staff but also of policies regarding the strictly excluded categories as well. This was seen nowhere more clearly than in the objections to the proposals of the Ministerial Order of 1941, for greater NSVJ participation in youth welfare work from Pflegekinderschutz (care of foster children) to Jugendgerichtshilfe (participation in the juvenile courts). the Kreisleiter of the office for Kommunalpolitik in Kassel greeted the proposed guidelines insofar as they would simplify the work of arranging for NSVJ participation. But that did not leave out of consideration the familiar problems which remained, the most obdurate of these being the question of the tendency of NSVJ honorary welfare provisions to be subject to frequent and disruptive changes of personnel. In any case, it was believed, they could not match either in training or experience the staff of the Jugendamter in Kassel. 3 The issue of the NSVJ exclusion of various 'unworthy' categories too

1. BA, NS $25 / 1233$, 'Stellungsnahme/NSV-Jugendamt/Kassel' n.d. (?1941).

2. Ibid.

3. Ibid. 
was raised, for it could pick and choose from among the existing cases of 'Aryan' individuals while the state officials in Kassel could not. ${ }^{1}$ To some NSV the extent had painted itself into a corner by $1940 / 41$ on the issue of staffing policies especially, but also with regard to the strictly applied guidelines on the exclusion of 'unacceptable' categories.

While at the level of the decision making process state and Party officials would continually find that an agreement which was acceptable to both parties might be hard, if not impossible to find; at the local level, at the very base of the system where individual welfare workers had to make arrangements to work together, it was clear that this was frequently both productive and even harmonious. Provided no jurisdictional problems had set in at the time, then NSVJ honorary workers worked in a variety of ways to assist the staff of the state Jugendamter. Families who had come under special notice such as 'asocial' ones or others who were in conflict with the regime, would find that cooperative efforts of state and Party welfare could be utterly devastating. When the NSVJ became aware of any case which needed attention from the state welfare offices it would alert the Jugendamt as soon as possible. Those families who were members of the International Bible Circle would find that an NSVJ helper would be prepared swiftly to altert the Jugendamt if they were unwilling to send their children to the HJ. Once this was discovered, then the Jugendamt would set in motion an order for the

1. Ibid. 
children to be placed under Vormundschaftsgerichtlichen Verfugung.'

The family effectively lost control over their children at this point. Either the state or the Party would become actively involved from this time on. Even the agreement to send a child to the $\mathrm{HJ}$ would not in itself remove pressure, for the child would then be included in the HJ's own 'Erziehungsarbeit', and it seems, continue to be under the supervision of the Jugendamt. Either way, the family would be unable to escape from the attentions either of state or of Party welfare. Strenuous attempts on the part of the NSVJ to cooperate in such work shows that the participation of honorary helpers might have been an ideal field for this type of 'policing' of the population. That it remained to masquerade under the title of 'welfare' only shows the direction of Nazi measures as they had been developing over time. On the other hand, at local level, state officials frequently questioned the efficiency of the NSVJ for, in practice, it was often unable to carry out the proposals which had been worked out in Berlin. The NSVJ offered to increase participation where no facilities existed, but once arranged, they would be hurriedly put together, so that to this extent it could be described as a 'dynamic' operation. The improvisatory nature of some of the NSVJ arrangements was something which the state officials worried over, and more frequently, deplored. But NSV facilities would remain in this form perhaps, until the outbreak of war, for it had taken time to build up an effective network of youth care

1. BA, NSD 30/11, Informationsdienst July 1939, see

'Jugendhilfe fur Kinder aus politisch unzuverlassigen

Familien', p.168-170. 
facilities. ${ }^{1}$ Even though state officials hoped that the NSV and its youth care section would restrict their ambitious schemes, it is clear that no such reduction would take place.

In 1943 the NSVJ would become more closely involved in the work of fursorge as well as in preventive welfare. It would be this development which promised the continued participation of Party welfare within the juvenile welfare system, even though some ambitions had failed to be realised immediately, as in 1941 over the arrangements for FE. The NSVJ would increase its facilities and offer an increased level of both 'treatment' and preventive care. Even though a partial solution was offered in 1944, and in favour of the Party agency, until that time these and other related issues would arise to complicate and to undermine the work of juvenile care in Germany from 1934 until just before the end of the war. It is impossible to say how far the new regulations of August 1944 would have provided a solution to the problem of the system of Party and state facilities for by that time, it was already too late for them to function effectively.

1. BA, NSD 30/11, Informationsdienst, July 1939; the section 'NSV - Jugendhilfe' provides fairly detailed information, including statistics, on the development of the NSVJ in the years 1936 to 1938. pp.177-179; see p.35, 'Aufkommen und Verwendung'. 
When the NSV claimed that it had broken new ground in establishing a type of child and youth care which depended for its success upon the principle of timely intervention, it gave the mistaken impression that such measures had never been tried before. The innovatory character of NSV policies was usually described to be due to this type of welfare activity, and it was seen as the basis of the 'success' of their measures. The much vaunted orginality of the NSV certainly comes into question in the light of the churches' own particular type of early intervention. ${ }^{l}$ Just like other welfare agencies the NSV had not entered upon unexplored territory; on the contrary, the Party agency, as it perfectly well knew, only followed in the footsteps of the churches, which had long since made preventive welfare a prominent feature of their own social welfare programmes. $^{2}$ Included in the extensive list of the responsibilities of the Catholic agency Caritas were the measures devoted to active participation in 'vorbeugende' (preventive) care. ${ }^{3}$ Health care and child care too were prominent features of Catholic charitable welfare work. To the extent that the Catholic church claimed the 'whole' person, training and education were both important and ideologically relevant features of the churches' activity in these areas during the 1920's. Preventive welfare of an ideologically-based type was not an

1. BA, R36/966, 'Festschrift zum Deutschen Caritas Tag 1928, Dresden vom 29. Mai-1. Juni'. Herausgegeben von der Săchsischen Volkszeitung, Dresden. n.d. (1928).

2. Ibid.; Friedlander, Child Welfare in Germany, see Introduction and Chapter One.

3. BA, R36/966, 'Festschrift/Caritas 1928', see p.5 for details of organisational outline. Caritas employed 80,500 specialist staff and had 600,000 members in 1928. 
innovation of the NSV alone.

Both Caritas and Innere Mission had provided until 1933 a sizeable amount of social welfare, both of a general type and also of specific child care measures, even allowing for the greatly increased input of the state's facilities after 1922. Before the Nazi takeover the Catholic church through its agency Caritas owned and operated 950 homes for 'Erziehungsfursorge', 770 hospitals and 382 recreational homes. This compares with a figure of 845 hospitals and 331 recreational homes still in operation in $1936 .^{1}$ No category which refers to 'Erziehungsfursorge' was included in the Caritas report to the DGT in $1936 .^{2}$ A comparison of the numbers of female staff (Pflegerin/Volkspflegerin) working in both denominational and NSV facilities in 1938 shows that the NSV had the largest amount with 1,500 while the denominational agencies between them employed the smaller figure of $1,200 .^{3}$ These figures show clearly that there would continue to be a substantial amount of church activity in almost every area of social welfare for some time to come, even allowing for the creation in 1934 of additional youth welfare facilities coming from the Party itself. ${ }^{4}$ State Jugendamter would continue to make many cases available to the denominational agencies, and allow a full use of certain particular specialist facilities such as reformatories and correctional homes, so that FUrsorgeerziehung

1. BA, R36/966, 'Festschrift/Caritas 1928', P.4; Ibid, Deutscher Caritasverband e.V., Hauptvertretung Berlin, report to DGT, 2lst January 1936 .

2. Ibid., Caritas to DGT, p.l.

3. BA, NSD 30/11 NS-Volksdienst July 1939,p.290.; see also Kramer, 'Das Fursorgesystem im Dritten Reich', which reproduces this table of figures, p.195.

4. See this Chapter. 
(FE) cases, in many instances, would be directed to church, not state or Party institutions. Given that the church had carried out such work over a long period of time, it is hardly surprising that the Jugendamter were prepared to send on cases to institutions, which in terms of strictness of regime, possibly surpassed even that of the state. ${ }^{l}$ This particular practice continued into the war to the chagrin of the NSVJ, and Althaus in particular. ${ }^{2}$ Neither the state nor the NSV could have replaced overnight the facilities of the churches. From the points of view of both popular opinion and, most importantly, financial constraints it would not have been possible to dispense with church facilities, nor for social welfare in Germany to become entirely secularised. As one state welfare official put it, they would have to wait until the end of the war when such changes could be made gradually and without causing too many problems for the leadership. $^{3}$ In 1935, Bormann's attention had been drawn to continuing high levels of denominational participation, which were preventing the NSV from taking on as many cases as they would have liked. In a letter to Frick, Bormann requested that he remind state officials that they had an agreement with the NSV whereby as many suitable cases as possible would be transferred to party facilities. ${ }^{4}$ Bormann stressed in his letter how important it was that a reduction of church welfare begin to make itself noticeable, for not to do this

1. Basic and Zonal Handbook, 'Youth Welfare', pp.17-19.

2. BA, NS $25 / 1233$ Hermann Althaus, report to Artur Axmann, 20th November 1940.

3. BA, R36/1996, 'Besprechung/preussischer FE/Uber NSV', 9th September 1941, see opinion of Landeshauptmann Kolbow, p.17.

4. BA, NS $25 / 105$, Bormann to Frick, 'Auslegung des Reichsjugendwohlfahrtsgesetzes', letter of 9th December 1935. 
would only prevent the 'Entkonfessionalisierung' of national life. However, the organisation and practice of youth welfare would not experience significant levels of secularisation, to the profound disappointment of the head of the NSV's youth welfare section, Hermann Althaus, and youth welfare would lag behind the NSV's kindergarten facilities in the extent to which the churches would be entirely exluded from taking a leading role in the work with young children. ${ }^{2}$ The Concordat of 8th July 1933 between the regime and the Catholic church had seen to it that the Catholic church, through section 1, of Article 31, would be allowed to continue to run and to operate those organisations 'devoted exclusively to religious cultural and charitable purposes'. 3 Caritas therefore came under this protection. It would not be until just before the beginning of the war that a more serious attempt would be made to exclude the churches from an area which the regime was determined to regulate, in terms both of organisation and of policy; this was of course the organisation of private adoptions. ${ }^{4}$

In 1939, a law was introduced which allowed for the removal of church participation in the work of private adoptions. This was the law of the 19th April 1939, the Gesetz Uber die Vermittlung der Annahme an Kindes Statt. ${ }^{5}$ From this time it would be an offence for any agency apart from the Jugendymter and the NSV, and shortly later

1. Ibid.

2. BA, NS 25/1233, Althaus to Axmann, letter of 20th November 1935.

3. Guenter Lewy, The Catholic Church and Nazi Germany, London 1964, pp.63-91.

4. BA, NSD 30/2, NS-Volksdienst, February 1938, pp.155-157; Christa Hasenclever, Jugendhilfe und Jugendgesetzgebung seit 1900, Guttingen 1978, p.148.

5. Ibid. 
the SS "Lebensborn" e.V., to be involved in this important field. Eugenic policies would be carried through strictly according to fixed rules regarding both children up for adoption and those parents wishing to adopt. ${ }^{l}$ The arrangements for private adoptions would therefore be taken over by the NSV and the "Lebensborn" homes, while the centrally organised Reichsadoptionstelle would exist as the main regulating body. ${ }^{2}$ No official role for the churches would exist from this time, and they would find that persistence in such work would bring severe penalties, even including imprisonment of those administering unofficial adoptions, and large fines. ${ }^{3}$ From 1941, such activity would come under the scrutiny of the Gestapo and, it seems, be subject to very severe penalties. The placing of 'Aryan' children in suitably 'politically reliable', 'racially desirable' homes was a matter in which the NSV, the SS and the Jugendamter would become closely involved. ${ }^{4}$

The rules of the Reichsadoptionstelle which the NSV carried through in its own office in Berlin, intended its dealings to be in line with the strictly laid down requirements of the law of April 1939. All future parents of an adopted child would have to prove their suitability in five areas, these were:

1. physical health/racial purity;

2. social worthiness/competence to guide young persons;

3. good reputation;

4. political reliability;

5. racial compatibility with child up for adoption.

1. BA, NSD 30/2, NS-Volksdienst, February 1938, p. 157.

2. Hasenclever, Jugendhilfe, pp.147-148.

3. Ibid.

4. Ibid.

5. BA, NSD 30/2, NS-Volksdienst, February 1938, pp.155-157. 
However from 1936, the NSV had been involved in the work of private adoptions in cooperation with the SS "Lebensborn" e.V., so that this particular development was not new. Suitable cases which required a discreet handling and which came to the attention of the NSV, were directed to the officials of the SS "Lebensborn" Home. These adoptions were arranged in the strictest secrecy to protect the individuals involved, and they were organised in such a way as to keep an illegitimate birth an entirely secret matter. Beyond the intruduction of such particular cases to the "Lebensborn" Home, the NSV may have had no further contact with these particular arrangements and it would remain as a matter which would be handled in complete secrecy by the SS Homes themselves. ${ }^{1}$

After 1939, the cooperation of the SS "Lebensborn" e.V., and the NSV was extended and, as Christa Hasenclever has pointed out, this work increased substantially with the additional responsibilities incurred by the arrangements for adoptions of chidren from the occupied areas. ${ }^{2}$ It is not clear whether these cases were processed through the Reichsadoptionstelle, or were a matter only for the SS and the NSV, although it seems likely that offical channels were used given the strict guidelines laid down. Nevertheless, the adoption arrangements carried out by the SS and the NSV seems to have been less carefully regulated, according to legal provisions regarding the adoption procedures themselves, as time went on. It seems that the NSV and the SS both arranged for a swift transfer during the war of

1. BA, NS 37ii/1030, instructions to Gauamtsleiter Amter fUr Volkswohlfahrt, Hilfswerk Mutter und Kind, 'Unterbringung werdender lediger Mutter in den Heimen des Vereins "Lebensborn" e.V.', 2lst March 1938.

2. Hasenclever, Jugendhilfe, p.148. 
procedures such as the signing of final papers, which allowed the adoptive parents to assume full parental responsibility at an earlier stage in the proceedings than the law itself had intended. The law had intended that this would be carried out at about the age of eighteen months, only then would the adopted child be legally allowed to be given entirely over to the new parents. Adoptions by the NSV and the SS would be processed very quickly without taking heed of the natural mother who, as Hasenclever points out, was pressured into signing away her rights over her child at a very early point in the adoption process. ${ }^{1}$ It seems that the law of 1939 was not closely observed in many cases during the war either by the SS, or by the NSV.

The exasperation of the NSV over continuing high levels of church participation came to a head at the end of 1940, when a report was sent to the office of the Reichsjugendfuhrer Artur Axmann, by Althaus, whose pent-up fury over the entire issue was manifest. In the first part of the report he revealed that, in spite of the 1939 regulations, the churches were continuing to play a very active role in placing children for adoption. This, he said, was having a detrimental effect on the activities of the NSVJ, which was virtually excluded from the adoption process as a result of the unacceptably high level of church involvement in it. While it is possible that Althaus was one of those Party activists who was so eager to act against the churches that he was prepared to disregard Hitler's strictures about the dangers of alienating popular opinion ${ }^{2}$ it is clear that he was also prepared to admit that the churches

1. Ibid.

2. BA, NS 25/1233, Althaus to Axmann, report of 20th November 1940, pp.2-3; Kershaw, Popular Opinion, p.333. 
were able to continue to play a prominent role in the adoption process almost by default, through the inability of the relevant state and Party agencies to work amicably together. ${ }^{l}$ The old rivalry between the NSV and the state Jugendamter consumed much of the energy of both, and prevented either from effectively countering the power and influence of the two denominational agencies in the whole field of social welfare. It was not the case that the church agencies always won their battles against the NSV or the Jugendumter - on the contrary, they often lost. But from his report it is clear that Althaus viewed with anxiety the way in which the Party agency's room for maneouvre was continually being circumscribed by the activities of the churches' agencies. ${ }^{2}$ This was seen by him to be one of continuing NSVJ exclusion at the same time as the churches continued to function at unacceptably 'high' levels. But it was, as he pointed out, as much the continuing difficulties with the state Jugendamter, which were allowing these practices to continue, as the popularity and influence of the two denominational agencies within the particular field of juvenile welfare. In other words, the churches were gaining almost by default, through the inability of the state and the Party to work together to organise child and youth care. For example, Nazi officials, perhaps rightly, saw the continuing participation of the churches to be less threatening than increased NSV power and influence within the system of juvenile care. Indeed, state officals who had to make arrangements for increased participation of the NSV in the provision of kindergarten care, were

1. BA, R36/1001, letter from Spiewock to Hilgenfeldt on use of church facilities in Berlin 1938, 17th May 1938.

2. BA, NS 25/1233, Althaus to Axmann, report of 20 th November 1940. 
liable to view the exclusion of the churches as offering an increased opportunity for an early NSV takeover of existing state facilities. For this reason they were liable to 'support' the continued existence of denominational kindergartens for as long as they could, or at least until firm agreements which protected the state facilities could be drawn up. These agreements over the NSV assumption of denominational kindergartens raised the fear that such agreements could be used in such a way as to facilitate an NSV takeover of state kindergartens at the same time. The inability of NSV and state officials to cooperate fully was only made worse by the nagging fear that a handover of denominati nn $^{n}$ al kindergartens was merely a prelude to a total exclusion of the state in the work of pre-school education. In this report and at this time, it was clear that Althaus saw the power and the influence of the Party agency coming under continued threat through the ability of the churches to take advantage of the situation ${ }^{1}$.

Firstly as Althaus pointed out, there was a continuing high level of institutional care (especially with regard to $\underline{F E}$ ) being provided because of the continuing willingness of many state Jugendamter to make use of the cheaper institutional facilities of the churches, rather than those of the NSV. Secondly, too many officials of the state were still reluctant to make better use of the NSV provisions because of the existing rivalry between state and Party officials. The churches would continue, Althaus suggested to provide social welfare for as long as they were allowed to do so. ${ }^{2}$

1. Ibid.

2. Ibid. 
However, one may argue that it is difficult to see how the HJ would have been able to assist the NSV in this matter for their own relations with it had been, if not entirely acrimonious, then not ideally cooperative. ${ }^{l}$ Althaus's report, which was intended to alert the $\mathrm{HJ}$, was being presented to the leading officials of an organisation with whom relations had been uneasy in many instances and entirely strained in many others. According to de Witt, a prolonged feud had existed between the HJ and NSV over jurisdictional issues. However, while it is true that the NSV had a certain monopoly of preventive child care, it is equally untrue to say, as de Witt does, that the NSV would eventually gain a monopoly in welfare work over the 'protection of juveniles' at the expense of the HJ. ${ }^{2}$ There is no reason to suppose that the $\mathrm{HJ}$ would lose control over its own active participation in the work of 'Erziehungsarbeit' or in correctional welfare as a whole. During 1941, in the discussions of the increased participation of the NSV in correctional education, the $\underline{F E}$ boards in Prussia were reluctant indeed to do anything that might jeopardise the good relations which had been built up over the years between themselves and the Hitler Youth leadership. ${ }^{3}$ On the contrary, as they said in 1941, an increased NSVJ participation in the administration and in the selection procedures of $\underline{F E}$ would almost certainly prove to be a provocative measure which the HJ would find to be unwelcome. It may even be true to say that such a

1. de Witt, 'The Nazi Party and Social Welfare', p.259.

2. Ibid.

3. BA, R36/1996, 'Besprechung/preussischer FE/Uber NSV', 9th September 1941, p.5. 
consideration figured largely in decisions to oppose the claims for a greater NSVJ input at this time. ${ }^{1}$ In addition, in 1943, the increased participation of the NSVJ in correctional education was conceived in relation to a proposed increased cooperation with the HJ itself. ${ }^{2}$ It would be wrong to say therefore that the NSV would gain a virtual monopoly in child welfare, not only in recreational facilities - which seems to be true - but in the 'care and protection' of juveniles as well. The $\mathrm{HJ}$ seems to have played a strong role in the administrative provisions of correctional education in relation to the $\mathrm{FE}$ boards, for this reason officials of the $\underline{F E}$ Boards were keen to stress the need to ensure a continuing peaceful cooperation with this particular organisation, regardless of the NSV it may be added. ${ }^{3}$

The longer these problems continued, and the more complicated they were, the more they threatened to compromise the Party's schemes for youth welfare provision in the indefinite future. The churches would only gain from this situation, as Althaus knew only too well, and he hoped to alert the leadership of the $\mathrm{HJ}$ to this particular 'danger'. 4 It may have been Althaus's intention that the $\mathrm{HJ}$ and the NSV together would be able to bring pressure to bear in order that the state's own provisions would be made more sensitive to Party claims within the whole field of juvenile care. ${ }^{5}$ But it does

1. Ibid., pp.1-17.

2. Hasenclever, Jugendhilfe, p. 150-152.

3. BA, R36/1996, 'Besprechung/preussischer FE/Uber NSV', 9th September 1941 .

4. BA, NS 25/1233, Althaus to Axmann, report of 20th November 1940. 5. Ibid. 
seem that it would take until 1943 for the NSV to become increasingly involved in correctional care at the expense of the churches, even though a partial monopoly had been gained in kindergarten care, in adoption procedures and in recreational measures themselves. More detailed research into the relationships between church, $\mathrm{HJ}$ and the NSV must be carried out before jurisdictional problems and other related issues can be fully understood. The period between 1940 and 1943 needs to be studied in some detail before a real understanding of these complicated problems can emerge. However, such an examination deserves a study devoted entirely to itself so that the following arguments may be regarded, through lack of space, as an initial study only.

Included in Althaus's report of 1940 was the serious suggestion that church activity in social welfare even with the 'asocial' and the 'hereditarily sick' juveniles should come to an end as soon as possible. Alternative facilities would then be set up and run by the state. $^{1}$ Such a suggestion, with its undisguised dislike of denominational facilities, shows how determined Althaus was to exclude the participation of the churches in youth care. But the suggestion also depended on two pre-conditions. Firstly that the regime could, in time of war, both fund and organise such a programme of increased state and Party youth welfare work. But secondly, that the regime could, regardless of the consequences, entirely ignore popular opinion in time of war; this was wildly far from the mark given Hitler's fears about the consequences of losing the support of the

- 1. BA, NS $25 / 1233$, Althaus to Axmann, report of 20 th November 1940, p.4. 
German People. ${ }^{l}$ Clearly, popular opinion would not be discounted, and the regime would find it difficult to reduce the participation of the churches in juvenile care and in child care as well. The vital issue of the maintenance of popular opinion demanded that, in Prussia, the correctional homes of the churches would be retained. As one state official in Prussia himself put it, to do otherwise would have been resented by a majority of the population who were themselves 'deeply shaken by the policies of the Nazis', which they saw as a threat to the right to a private existence and, importantly, the freedom to worship. ${ }^{2}$ The extent to which the Party had been seen to forsake such values threatened a weakening of support for the regime itself; state officials in Prussia were unwilling to disturb matters further by making changes in the organisation of denominational youth homes. ${ }^{3}$ It would be for these reasons that the NSV would find itself when confronting the vitally important structural problems of the social system, that it was at the mercy of forces ${ }^{\text {over }}$ which it had little or no control. From this point of view, Althaus' report would remain just another one of many documents in which there was an outline of problems but little hope of solution. It may have been that Althaus's deep dislike of continuing church activity was as much fuelled by this realisation as by a deep seated objection to the practice of denominational care as such. If popular opinion demanded that church participation in correctional care continue, as the example of Prussia in 1941 showed,

1. Kershaw, Popular Opinion, pp.334-336.

2. BA, R36/1996, 'Besprechung/preussischer FE/Uber NSV', p.17.

3. Ibid. 
then there was little or nothing that Althaus could do if state officials, but also the leadership in Berlin, had no intention of putting to the test the most deeply held prejudices and preferences of the population at large. ${ }^{1}$

While Althaus could see the reasons for the state being prepared - at least on the issue of cost - to allow continued high levels of church participation, he could not see why there should be a continuing a high level of adoptions as well. Even allowing for exaggeration in his report in order to drive home the point, there seems to have been some truth in the claims that the churches were still carrying on with the work of adoptions even though they were forbidden to do so by the law of $1939 .^{2}$ Even if the churches were not themselves intending to carry out their work in a provocative opposition to the NSV, nevertheless a close scrutiny of all adoptions was made the more difficult by an unofficial programme which the churches seem to have been involved in, even if it was less in volume than Althaus feared it to be. ${ }^{3}$ Less serious, but equally irritating was the realisation at the end of 1940 that denominational recreational work was carring on apace. Again, the churches were continuing to participate in an area in which the NSV had become closely involved. Apart from the MuK (Mutter und Kind) holidays for mothers scheme, the NSV also provided recreational facilities for adults and children through, on the one hand, the 'Erholungshilfswerk' and on the other the 'Kinderlandverschickung'

1. Stephenson, 'War and Society in Werttemberg', p.89.

2. BA, NS 25/1233, Althaus to Axmann, report of November 1940, p. 2 .

3. Basic and Zonal Handbook, 'Youth Welfare', p.17. 
schemes. The intention that all recreational facilities would eventually come under the direct responsibility of the NSV was put forward by Althaus in his report of 1940. He proposed that the NSV should, as quickly as possible, assume total control over all confessional recreational homes. For, as he put it, of the existing 520,000 places which were available at the time, 110,000 were still, 'in the hands of the two confessional agencies'. ${ }^{1}$ However it may be that this issue was decided by the conduct of the war, for in 1940, while the NSV sent away 518,705 children for a country or other type of break, in 1941 this figure would fall to $262,267 .{ }^{2}$ The NSV would, in any case, soon become very closely involved in the work of evacuation in which it would have a monopoly, so that the matter of church recreational facilities was partly solved given that the NSV would have the right to appropriate suitable denominational homes in which to accommodate evacuated children from the bombed-out areas of Germany. 3

It seems that during the war, from about 1941, the welfare activities of the churches began to be less 'obvious'; in other words, it went 'underground' to some extent when the continuing work of church welfare began to be carried out, as far as possible, out of reach of the knowledge of the NSV. To a large degree it must have been that further church work in adoptions had gone 'underground' given the penalties involved for such continued participation. It may have been that the Catholic church, especially, had found ways of escaping detection, as Althaus seemed to indicate, for if such work

1. BA, NS 25/1233, Althaus to Axmann, report of 20th November 1940, 'NSV - Jugenderholungspflege', pp.2-6.

2. BA, NSD 26/26, 'Aufkommen und Verwendung', p.32.

3. Basic and Zonal Handbook, 'Youth Welfare', p.17. 
were only being carried out 'illegally' then it must have been organised only at the level of the parish where a local priest could undertake to participate secretly in the work. ${ }^{l}$ In any case, ways of continuing such work had been found, as the report from Althaus shows. Due to the determination on the part of Catholic priests to encourage people to avoid the NSV which seems to have been building up during the war, the Catholic church had begun as far as possible to avoid active contact with the NSV. This in particular involved trying to prevent the NSV getting control over Catholic children in their evacuation procedures. Catholic priests themselves arranged for the evacuation of children, before the NSV with its legal monopoly ${ }_{2}^{\text {rould }}$ have the opportunity to make arrangements. Certainly doubt is cast by this on the popularity of the NSV and its measures and this was something which state officials too remarked upon. ${ }^{2}$

For as long as uncoordinated policies regarding church participation continued, then the NSV would find that the denominational facilities would continue to flourish thereby taking up many cases which could have been dealt with in NSV homes. While it is true to say that the state officials were, in many instances, quite willing to continue to use denominational homes and other institutions (as in the past) this was only true of some Jugendamter but not others. Even if, as Althaus suggested, this seemed to be true of a majority of state youth welfare offices this is not to say that in some areas, such as Hessen-Nassau that a Gauleiter would be willing to use these for longer than was absolutely

1. Ibid.

2. BA, R36/1996, 'Besprechung/preussischer FE/Uber NSV', 9 th September 1941 . 
necessary. ${ }^{l}$ In these cases at least, the NSV would find that its own facilities would be preferred over those of existing denominational ones in the area in question. Inevitably, these particular developments would largely depend on levels of existing need and these too would determine how far, and for how long, church facilities would be expected to provide continuing care for young people.

1. BA, NS 25/1158, Gauleitung Hessen-Nassau to Frick, letter of 16th September 1941 . 


\section{CHAPTER SIX}

\section{THE HEALTH CARE MEASURES OF THE NSV}

NSV preventive health care consisted of various measures of a supportive type from the care of children from infancy to adolescence, to financial support schemes for TB patients in order to help combat Tuberculosis in Germany. ${ }^{l}$ Holidays for young children would be organised through the NSV and these were conceived within the structure of the NSV's preventive health care as a whole. NSV adult holiday schemes were also available apart from the 'Mother and Child' holidays, though these seem to have been only of minor significance in relation to the main holiday provision for children, the Kinderlandverschickung or KLV. The NSV would also organise and run an order of nursing sisters the NS-Schwesternschaft, and it would be this particular group of nurses who would be sent to the border areas of Germany in 1938/39, to the occupied areas in the east, and to France and Belgium after $1940 .^{3}$ It seems fair to say that Hilgenfeldt was genuinely interested in the kindergarten and child care provisions as a whole, and he was completely determined to establish his own NSV pre-school facilities throughout Germany by taking control gradually over the kindergartens of the churches and the other private facilities still in existence. The NSV would also come to assume a powerful position in relation to growing developments in pre-school education in war-time, and it would be the

1. BA, NS37ii/1014, organisational outline, 'Amt fUr Volksgesundheit im, Hauptamt

fUr Volkswohlfahrt', 1936.

2. BA, NS 25/1162, Fol. 1, VB, 'Zehn Jahre NSV', article by Hilgenfeldt 1943; Ibid., 'ein Volk hilft sich Selbst: ein Jahrzehnt NS-Volkswohlfahrt' 1943.

3. BA, NS 37ii/1039; 1041 . 
war itself which would ensure that the NSV's incursion into this particular area would continue to develop and to increase. ${ }^{1}$ By 1941 it would be clear to state officials that the NSV would be allowed to take on the running and organising of all the new kindergartens which were intended to be provided at this time. ${ }^{2}$ New facilities being planned would therefore become part of the NSV's growing empire rather than being included within the provisions of the state which, for long, especially in Munich, had been running extensive kindergarten facilities of its own. NSV kindergartens, or NSV-run kindergartens, would be established throughout the Altreich but also in the occupied areas of the east. In Hungary too, the NSV would establish its health/welfare facilities for mothers and children which, according to the NSV there, proved to be very popular and promised to grow substantially, at least until 1943, when the Russian advance came to interrupt the work of the Party's welfare organisation in that country. In the Ukraine a slowly developing but successful set of NSV welfare/health care measures would have to be abandoned when it became necessary to evacuate the Volksdeutsche (ethnic Germans) from that area. ${ }^{3}$ However, until that time, the NSV would flourish outside the boundaries of the Altreich, from Alsace-Lorraine to the eastern borders of Hungary. ${ }^{4}$

There is every reason to believe that the future development of

1. BA, NS 25/1158, Bormann to Fiehler, 'Ubernahme neuer Kindertagestatten durch die Hauptstadt der Bewegung', letter of 16th August 1941.

2. Ibid.

3. BA, NS $26 / 261$, see report to Berlin on the activities of the NSV in the Ukraine, lst November 1943.

4. Ibid. 
the NSV lay with its health-oriented welfare measures, and these would show themselves to be popular with the head of the Office for the People's Health, Dr. Conti. ${ }^{l}$ Conti and Hilgenfeldt seemed to enjoy a good working relationship which had begun in the period of the end of the 'time of struggle'. Conti had allowed the still unacknowledged (by Hitler) Berlin-based organisation to arrange for holidays for children, and he certainly seems to have counted the later contribution of the NSV to preventive health care as an important one. He seemed, in addition, to view the future participation of the NSV as a vital part of future health care arrangements in Germany. For this reason a victorious war might have seen the NSV further expanding throughout this particular area. ${ }^{2}$

To understand the construction of the health/welfare schemes of the NSV it is necessary to look first of all at the country holidays for children whose importance was certainly acknowledged by Hitler. He ordered that they should be continued even in time of war and after beginning of the bombing raids over Germany. At the end of 1942, he expressly ordered that the Kinderlandverschickung (KLV) be continued as far as that was possible. ${ }^{3}$ The KLV however should not be confused with the EKLV, or Erweiterte Kinderlandverschickung, which was an evacuation measure entirely, and which was established in 1940 and placed under the direction of von Schirach, not

1. BA, R18/3793, 'Zur Neuordnung des Gesundheitswesens nach dem Siege', speech of Dr. Conti, (?September) 1943.

2. Ibid.

3. BA, NS 37ii/1010, from Lammers to all Reich Ministers, 'Kinderlandverschickung', letter of 17th December 1942; Ibid., 'Kinderlandverschickung 1943/44', 'Verteilungsplan', February 1943. 
Hilgenfeldt. ${ }^{1}$ The NSV would cooperate and participate in the EKLV, but it did not itself run the scheme; in effect, the EKLV was a joint operation which involved the HJ, NSV, NSF and other Nazi organisations in what was essentially an emergency measure rather than a recreational one. ${ }^{2}$ The KLV, on the other hand, was one of the NSV's own favourite holiday schemes and other Nazi organisations which participated in the KLV would do so in cooperation with the NSV, not the HJ.

1. BA, NS37ii/1011, 'Anordunung des Reichsleiters von Schirach', new war-time regulations, 30th September 1943.

2. Ibid. 
'The present regime shows that it has no intention of trying to win over the nation by coercive methods but rather the whole hearted suffrage of the public through the influence of practical and visible results'.

One of the practical ways of gaining popular support was to make provisions for the annual sending of children from town and cities to the country areas, to the lakes and, where possible, to the sea-side as well. Kinderlandverschickung was regarded by the NSV as a most important and potentially popular facet of the provision of health care for young children, who might not otherwise have enjoyed a country break or other type of holiday. ${ }^{2}$ A spell in the country, perhaps up to six weeks in duration, was viewed as being capable of having a profound impact on the well-being of the children involved. ${ }^{3}$ The NSV fully intended that the child's holiday trip away from the city or the town would provide not only a recuperative spell for those in most need of it, but that the holiday itself would have an important 'educative' function. Werner Reher emphasised how children would return refreshed by the whole experience of being in the country, which no doubt in most cases they were, but also that the child would 'relate the wonders and the beauties of the countryside to his companions on his return'.4 One of the unintended consequences of the KLV was to reveal to Gau officials the neglected and poverty stricken condition of some of the children being sent

1. Reher, Social Welfare, p.24.

2. Ibid., p.25.

3. Ibid., p.25-26.

4. Ibid. 
into their own Gau areas. ${ }^{1}$ Children were sent into the Gau Sachsen without adequate shoes on their feet and with insufficient clothing, so that Gau officials would have to arrange for shoes and clothing to be given to those in most need. Other problems such as behavioural ones would be revealed to the host families, and holiday 'mothers' would find that wash-day would be greatly lengthened by the need to provide clean linen for chronic bed-wetters. ${ }^{2}$ The free-place accommodation which would be provided by farmers' families was a most popular method, as far as the NSV was concerned, of giving a country holiday to young children even though they would need to make efforts to raise enough places for the KLV schemes. One way of doing this was to advertise for free holiday places from those who could be expected to provide them. Specially contrived messages, supposedly from children to their parents, were supplied on post cards to the local Party offices and they were either displayed in the Party offices or were sent off to farmers and others who might offer a free place that summer. Children could also use the postcards for sending to their parents without the specially contrived text. To farmers who might offer a place would be sent postcards with pictures of children on a hay-waggon and the supplied message would read:

'Often the country-folk would take me to work with them in the fields and that was great fun'.

Or a harvest scene with NSV holiday children would be provided and would carry the following message:

'Today I have been helping - that was wonderful'.

To a prospective giver of a free place from the more prosperous

1. BA, NS 37ii/1062, Gau Sachsen, 'Stimmungsbericht der Wohlfahrtsabteilung' (331256), May 1935.

2. Ibid. 
would be sent postcards showing the message:

'It is lovely here, I play the whole day in the garden with the other children and eat as much as I like'.

The writing on the cards imitated a childlike hand and care was taken to see that the correct card was sent to the appropriate prospective host family. A call from the Gauleiter or NSV Gauamtsleiter would be put on the reverse of the card saying:

\begin{abstract}
'In countless numbers of letter and cards comes the description of the joy and happiness of children on holiday. We would like you to help us bring this happiness to children and ask you therefore to donate a free place for a child on an NSV holiday.
\end{abstract}

Such measures show how precisely the propaganda of the NSV took into account every detail with regard to arousing interest in the children's holiday scheme. ${ }^{3}$ NSV holidays, whether they were part of the holiday schemes for mothers through the Muk, or whether they were part of the children and young persons' schemes, should be regarded as a preventive health and welfare measure even though they were also clearly meant as a propaganda measure to drum up support for the leadership. All NSV holiday schemes including the KLV, were provided on the basis of a renewal of physical health and strength as well as giving an opportunity to contemplate at leisure the attractions of the countryside. ${ }^{4}$ The Nazi belief in the influence of the natural environment as a potentially strengthening one was a darker representation of other, not altogether unsimilar, back to nature movements of the 1930's, which stressed the importance of rambling or

1. BA, NS 22/751, 'Werbepostkarten fUr Kinderlandverschickung', 27 th July 1936.

2. Ibid.

3. Ibid., 'Terxtvorschlag fur den Aufruf'.

4. Reher, Social Welfare, pp.25-26. 
in other ways discovering the benefits of the countryside.

The Nazi 'back to nature' movement however was a less simply conceived one with its emphasis upon finding one's roots in the soil of Germany in order to achieve an understanding of the 'strength' of the racial/tribal group. Many could have been forgiven, when looking through the NSV publication Ewiges Deutschland, for believing that Germany was a land of farms and countryside pursuits peopled by hardy peasants whose love of hard physical labour had marked them with a rugged cheerfulness which could, moreover, sustain them in every adverse situation. ${ }^{1}$ However, the NSV leadership was well able to comfortably accommodate the inherent contradictions of its own propaganda which drew a picture of an archetypal Germany which existed only in the minds of those who, in a very small number of cases only, might have been carried away by the portrayal of a bucolic paradise. However, these dark, romantic fantasies did not prevent the NSV leaders from understanding how important it was for them to exclude the churches from the provision of recreational breaks for the young. Althaus hoped, in 1941, that it would soon fall to the NSV alone to make arrangements for this type of welfare measure, for there was no doubt that he deeply resented the continued participation of the churches in such work. ${ }^{2}$ It seems that the NSV and the Reichszentrale Landaufenthalt fUr Stadtkinder e.V. shared the task of sending children away on holiday from towns and

1. BA, NSD 30/9, Ewiges Deutschland, March 1939, see 'Volk und Sprache in Schleswig-Holstein', pp.83-84.

2. BA, NS 25/1233, Hermann Althaus, report to Artur Axmann, 20th November 1940. 
cities in Germany. It also seems that the Reichszentrale undertook to dispatch the largest number of children, with the NSV arranging for the smaller amount of between one half and one third of the total number of children to be sent away. ${ }^{1}$ The Reichszentrale figures were included in the NSV statistics and this organisation was itself closely connected with the NSV; it had virtually become an adjunct in perhaps the same manner as the nursing organisation, Reichsbund der freien Schwestern. ${ }^{2}$

From 1940, the Kinderlandverschickung programme was altered to include the measure called the Erweiterte Kinderlandverschickung scheme which was set up to move children out of the bombed areas for lengthy periods of time should that be necessary. This meant that the EKLV was really an evacuation scheme which could be used as the occasion arose. ${ }^{3}$ However, this and other evacuation schemes will be dealt with in Chapter Seven. ${ }^{4}$

The numbers of children who were sent away by the NSV and the Reichszentrale each year from 1933 to 1941 (including the EKLV) were as follows:

1. BA, NS 26/261, 'Aufkommen und Verwendung', p.32.

2. BA, NS 37ii/1039, 'Anordnung Nr. 1', 28th March 1934; Ibid., 'Vorlaufige Richtlinien fur die Schwesternschaft der NSV'.

3. Ibid., BA, NS 37ii/1010, instructions to NSV officials, 'Erweiterte Kinderlandverschickung und Umquartierung aus Luftschutzgrunden und wegen Fliegerschaden', 14th July 1943.

4. Ibid. 


\begin{tabular}{lcc} 
Year & Reichszentrale/Einschl.Ortliche & NSV \\
\cline { 2 - 3 } 1933 & 352,501 & 139,855 \\
1934 & 646,065 & 386,823 \\
1935 & 645,368 & 435,042 \\
1936 & 632,190 & 444,340 \\
1937 & 665,138 & 488,917 \\
1938 & 873,841 & 693,491 \\
1939 & 681,902 & 515,951 \\
1940 & 726,047 & 518,705 \\
1941 & 398,589 & 262,367
\end{tabular}

\section{Erweiterte Kinderlandverschickung}

1940

204,967

137,239

1941

576,499

389,963

From the figures given above, it is seen that the year 1938 saw the largest numbers being sent away with a drop in numbers in 1940 and 1941 showing the response to war-time conditions, and the beginning of bombing raids over Germany.

That the NSV saw the children's holiday scheme as one of its most important health care projects was shown by the report from the NSV Gauhauptstellenleiter of East Hanover who included some research findings on the KLV in the NS-Volksdienst in July 1940. ${ }^{2}$ Such holidays were viewed as a serious exercise in improving the general physical condition of children. In Berlin and Hamburg a study was

1. BA, NS 26/261, 'Aufkommen und Verwendung', p.32.

2. BA, NSD 30/4, NS-Volksdienst, 'Die Kinderlandverschickung als vorbeugende Gesundheitsmassnahme', July 1940, pp.126-133. 
made of the effects of the KLV trip on children sent away in $1939 / 40 .^{1}$ For example the findings indicated that the health and well being of the Hamburg children, 3,827 in all, were greatly improved on their return home from the countryside. For 768 of the children, the holiday had greatly benefited their physical condition and they had all put on some weight; these were given the result 'very good'. For 2,282, the holiday had proved to be 'good', and for 731, 'medium'. 2 Those described as having benefited not at all - 'no success' amounted to 46 . Following this examination of the children it was decided that further measures for a total of 819 of them would have to be taken later in the year. ${ }^{3}$

In Berlin, too, one Kreis had made a similar study of the returning KLV participants and, in addition, made an examination of the weight gains of all the children which showed an increase of between $2.05 \mathrm{~kg}$ and $2.71 \mathrm{~g} .{ }^{4}$ of the numbers of Berlin children who had been sent to Thuringia, Mecklenburg and Schlesien the Berlin Kreis reported as follows with regard to the percentage of children sent to each area and in relation to their general condition on their return:

1. Ibid., p.131.

2. Ibid.

3. Ibid.

4. Ibid. 


\begin{tabular}{cccc} 
Thuringia & Mecklenburg & Schlesien & Remarks \\
\cline { 2 - 4 }$\%$ & $\%$ & $\%$ & $\%$ \\
34.1 & 55.6 & 39.2 & very good \\
40.4 & 44.4 & 39.2 & good \\
19.2 & - & 21.6 & medium \\
6.3 & & & bad
\end{tabular}

Average weight gain $\mathrm{kg}$.
2.05
2.8
2.7

From the figures given above it seems that the best area to send a child on holiday was to Mecklenburg in this particular instance; though from another table given it was shown that perhaps other areas which offered a similar opportunity for a child to put on weight if he was in need of nourishment, were East Prussia and Pomerania, as for example:

$\begin{array}{cccc}\text { East Prussia } & \text { Pomerania } & \text { Kurmark } & \text { Remarks } \\ 45.5 & 55.6 & 45.0 & \text { very good } \\ 36.2 & 25.8 & 30.0 & \text { good } \\ 18.2 & 12.9 & 15.0 & \text { medium } \\ - & 6.7 & 10.0 & \text { bad }\end{array}$

Certainly from these figures and the ones given above it seems that holiday places either in Thuringia or Kurmark, did not offer the same advantages as those in East Prussia. ${ }^{3}$ However, precisely the same accommodation facilities were not necessarily on offer every year and the research which was undertaken was not intended only to discover how good or bad these had been. As suggested above the figures were compiled mainly to discover what the physical condition of children

1. Ibid.

2. Ibid., p.132.

3. Ibid., p.131-132. 
was on returning home from the country. ${ }^{1}$

The practice of sending children to board with farmers' families, which was significantly revived after 1933, was a measure which was criticised by Walter Friedlunder in his study, ${ }^{2}$ and he certainly seemed to believe that children would be better off in holiday homes. The figures which he gave showed clearly that the 'free place' accommodation in farmers' homes was greatly preferred from 1933. This was shown with regard to the development of the KLV schemes (and earlier children's holiday schemes) from 1923. The figures show the distribution of holidays according to use by the city of Berlin alone.

Berlin: Holidays for children from 1923 to 1934

\begin{tabular}{lccc} 
Year & In Chiliren's & Farmers' & Foreign \\
\cline { 2 - 3 } & $\underline{\text { Homes }}$ & & Families \\
1923 & 6,700 & 41,200 & 480 \\
1924 & 15,800 & 25,800 & 2,130 \\
1929 & 41,946 & 12,041 & 1,797 \\
1930 & 30,428 & 11,261 & 1,158 \\
1931 & 27,319 & 14,334 & 1,805 \\
1933 & 1,980 & 44,600 & - \\
1934 & 2,290 & 49,500 & -
\end{tabular}

From these figures given above it is clear that during the Nazi period the total number of children sent away on holiday was not increasing markedly in comparison with the period of the Depression, as for example:

Total number of children sent on holiday in Berlin.

$$
\begin{array}{cc}
1929-55,784 & 1930-42,847 / 1931-43,458 \\
1933-46,580 & (4) \\
1934-51,790 &
\end{array}
$$

1. Ibid., p.133.

and Meyers,

2. Friedlander $\wedge$ Child Welfare in Germany, pp.64-67.

3. Ibid., p.64.

4. Ibid. 
This is to say that the figure for $1934(51,790)$ had not managed to catch up with that of the year $1929(55,784)$ even though it exceeded the 1930 figure of 42,847. In other words, as Friedlunder has pointed out, the figures of the Nazi period (see above) were hardly impressive with regard to the arrangements for children's holidays in the capital of Germany. This is not to say that increases were not registered at a national level, for the numbers of children given a holiday throughout the Reich amounted in 1933, to 352,501 and in 1934 , to $646,065 .^{1}$

The NSV had not of course (as the figures above show) been the first to organise the holidays for children schemes and they were only carrying on with a long tradition of providing holiday arrangements for those most in need. According to reports from Gau Sachsen, the activities of the KLV were popular, and the fact that new facilties and homes for the use of the KLV scheme were being developed suggests that the NSV did not intend completely to abandon the practice of making use of holiday homes. ${ }^{2}$ Two new homes were opened in Sachsen in 1935, which accommodated 137 during that year. ${ }^{3}$ It seems that the children from Sachsen were sent into Hessen-Nassau or to Kurmark, and it was reported that 1,100 Sachsen children came back after 'a really good holiday' from these areas. 4 During 1935, Sachsen accommodated children from Essen and Danzig numbering 1,265 in all. However, it also seems that apart from problems such as bed-wetting and poorly clad children, host families were also

1. BA, NS 26/261, 'Aufkommen und Verwendung', p.32.

2. BA, NS 37ii/1062, Gau Sachsen, 'Stimmungsbericht', May 1935.

3. Ibid.

4. Ibid. 
reporting to the Gau office in Sachsen that children were arriving in a poor medical condition and were sometimes infested with lice, but certainly in a dirty state generally. This information caused the NSV officials in Sachsen at least to establish new regulations regarding their own KLV schemes by trying to ensure that their children would not arrive in other Gaus in a similar state. From $1935 / 36$ it seems that medical examinations of children going on KLV holidays were tightened up. It may have been that the appearance in other Gaus as well of children with behavioural and other problemis did allow some possibility of a better arrangement for pre-KLV medical examinations of those children going away on a holiday. For this had certainly been an intention of the NSV scheme, namely, that only those children who were physically well at the time should be sent off in order to stop the spread of illnesses such as diptheria, and other infectious diseases. It seems however that NSV guidelines to prevent the spread of serious illnesses were not always followed and in 1936, Hilgenfeldt had had to remind his staff to take more care over medical examinations in order to prevent the spread of diptheria especially. ${ }^{1}$ However, for the less immediately serious problems of bed-wetting or other behavioural problems it seems that NSV staff would, at least in Sachsen, try to make sure that they had made arrangements to discover those children who might have to be considered in advance of a KLV trip. ${ }^{2}$ From this point of view alone, it seems that the KLV might have been useful for revealing to NSV staff what the less obvious needs of children in their Gaus were, and

1. BA, NS22/751, Hilgenfeldt to all Gauamtsleiter NSV on guidelines for prevention of diptheria, lst April 1936.

2. BA, NS 37ii/1062, Gau Sachsen, 'Stimmungsbericht', May 1935. 
even if they only dealt with them in order not to reveal these to a neighbouring Gauamtsleiter, at least it would be a gain for the child as well as for the reputation of the local NSV office. 
In an article in the NS-Volksdienst on the ten year existence of the NSV's 'Mother and Child scheme', an opportunity was taken not only to write about the MuK as a whole, but to give a detailed outline of NSV facilities such as the existing arrangements for NSV kindergartens and day-care nurseries. ${ }^{1}$ Within NSV kindergartens both health and recreational care were described as being an intrinsic part of the whole enterprise, forming the basis of the care of very young children by the NSV on a daily basis. Far from looking after these children from the point of view of allowing a respite to mothers who were not themselves working outside the home, NSV kindergarten care was meant to play a far more serious part in National Socialist education as a whole. The NSV kindergarten was meant to supply an additional educational facility of much importance in the light of the NSV provision of 'Menschenfuhrung'. 2 The promotion of the health and well-being of growing children was not only seen by the NSV to be a vital part of kindergarten care but the kindergartens themselves were seen as a fundamental contribution to the future development of each child within Nazi society. 3 Up-to-date knowledge both of biology and of child-care methods was intended to support the work of the NSV kindergarten nurse who would be entrusted with the care of 'Aryan', 'biologically worthy' children of politically reliable parents. In other words, the NSV would put into operation its normal entrance requirements and refuse to include

1. BA, NSD 30/4a, NS-Volksdienst, 'Zehn Jahre Hilfswerk Mutter und Kind', December 1943, pp.161-182.

2. Ibid., Section 4, pp.175-179.

3. Ibid. 
those children who .. they had deemed to be unacceptable. ${ }^{1}$ NSV kindergarten care was considered from the point of view of a 'balanced alternation' between rest, play and physical exercise, all three of which were required by a growing child in carefully managed proportions. 2 Support for the physical development of the 'normal' child was meant to be provided by the measures of a health care programme which was designed around a careful consideration of the dietary needs of very young children. ${ }^{3}$ It seems that the NSV provided well-run kindergartens and nurseries, for this seems to have been an area in which they showed themselves to be efficient, as one state official at least was prepared to admit. ${ }^{4}$ Given that a keen effort was made to supply good nourishment in the kindergartens themselves, and to educate mothers in the best ways in which their children should be fed, it may be that the NSV kindergarten was capable of making a real contribution to the general health of young people. 5 The specific health care provisions of the NSV kindergarten also included meașures to combat rickets, indeed to provide special treatments in the kindergarten itself to remedy the effects of this particular disease with vitamin and sun-ray treatment being given in most nurseries. The NSV regarded its kindergarten provisions as

1. Ibid., p.175.

2. Ibid., pp.175-176; BA, NS 37ii/1031, 'Stoffplankindergärtnerinnen', 1942; 'NS-Seminar fUr soziale und sozialpaddagogische Berufe: Staatliche anerkanntes Seminar fur Kindergärtnerinnen.'

3. Ibid.

4. BA, NS 25/1158, 'Tatigkeitsbericht des Gauamtes fur Kommunalpolitik', Sachsen, July 1941.

5. BA, R36/1396, VB, 'Alle Hilfe fur Mutter und Kind', 17 th May 1942 . 
being a first step in the National Socialist education of the new generation; it was also to be seen as a not-to-be underestimated 'Kulturfaktor'. I

However, the NSV explained that such child-care measures needed to be given support within the home, and for this reason parents, and the mothers in particular, would have to be given instruction on the new type of health care for children which the NSV hoped to encourage. The difficult task of ensuring a continuity in emphasis and in method meant that the NSV kindergarten nurse was entrusted with the important task of trying to create a good relationship with the parents of the children attending the kindergarten. ${ }^{2}$ To this purpose, parents but mothers in particular, were expected to attend special 'parent evenings' where the NSV staff would take the opportunity to explain their work and introduce parents to the NSV programme of child care which, it was intended, the parents should continue at home. ${ }^{3}$ Not surprisingly, a close cooperation existed between the kindergartens and the NSV's 'Mother and Child' scheme which was supposed to send on information on all needy cases to the local NSV kindergarten, and mothers were usually persuaded to take up a place for a child who was in 'need' of NSV child care. ${ }^{4}$ For those who could not pay, NSV kindergartens would not make a charge.

There existed several types of kindergarten which served different purposes in relation to the situation of working mothers. For example, the Harvest Kindergartens were set up during the summer

1. BA, NSD 30/4a, NS-Volksdienst, December 1943, p.176.

2. Ibid., pp.176-177.

3. Ibid.

4. Ibid., pp.178-179. 
months specifically to aid farmers' wives who were required to work especially hard during harvest time. As the NSV put it, 'for the Landfrau whose work makes her child-care duties something which has to be done in addition to her work as a farmer's wife', the Harvest Kindergartens (Erntekindergarten) would provide extra help in time of special need. These were organised for the duration only of the summer months. In the summer of 1934 the NSV managed to provide 600 of these for farmers' wives. ${ }^{l}$ The importance of this particular measure was recognised in the provisions of the Four-Year plan, for in 1936, extra Harvest Kindergartens were made available; indeed, they were a part of those NSV facilities which were designed to aid working married women with children and these also included city based Hilfskindergarten. ${ }^{2}$ Given that no Gemeinde, according to the NSV's publication, the NS-Volksdienst, was able to provide a really significant level of increased kindergarten facilities it had fallen to the NSV to provide these. The state provisions were liable to suffer from 'shortages of personnel' so the NSV pointed out, hence the valuable contribution of the NSV's new provisions. ${ }^{3}$ This suggestion was true to some extent, but to suggest that the NSV itself was not liable to suffer from shortages of personnel was of course to paint a false picture for it had to make strenuous efforts to find enough staff; not least of these was the tendency to pay more than the state welfare facilities could, in order to attract suitable numbers of staff. ${ }^{4}$ The importance of the Harvest Kinder-

1. Ibid., p.177.

2. BA, NS 26/261, 'Aufkommen und Verwendung', p.25.

3. BA, NSD 30/4a, NS-Volksdienst, December 1943, p.175.

4. BA, R36/1996, Dr. Schow to DGT, 12th August 1941 . 
gartens as laboy on the land became ever scarcer was shown in the rise in the numbers of these between 1934 and 1936. From a figure of 600 in 1934, the Harvest Kindergartens rose to 751 in 1935, and 1,410 in 1936. The numbers of places available therefore were as follows:

$\begin{array}{rrrrrr}1934 & 17,538 & 1937 & 131,765 & 1940 & 226,419 \\ 1935 & 26,534 & 1938 & 168,864 & 1941 & 261,453 \\ 1936 & 49,563 & 1939 & 279,562 & & (1)\end{array}$

Also within the framework of the Four-Year plan were the 'work place' kindergartens which came under the auspices of the DAF and its own Frauenamt section. For this reason, no figures were included with regard to these in the NSV's own statistics. ${ }^{2}$ During the war there was, of necessity, an increase in kindergarten facilities both of Harvest type and including new ones which were set up in the industrial areas and named Hilfskindergarten ${ }^{3}$ At the outbreak of war, 1,949 of the new Hilfskindergärten were set up, offering altogether 73,497 places. This provision would steadily increase so that by 1941 , there were placed at the disposal of those mothers who wished to work (not a compulsory duty in time of war for mothers with children, nor indeed for single women until January 1943), 3,654 new kindergartens with 129,033 places. These were of course in addition to the existing arrangements for nursery care. The numbers of Dauerkindergärten (permanent kindergartens) were as follows from 1935 to 1941 :

1. BA, NS 26/261, 'Aufkommen und Verwendung', p.27; Wunderlich, Farm Labor in Germany, p.318.

2. BA, NSD 30/4a NS-Volksdienst, December 1943, p.178.

3. BA, NS 26/261, 'Aufkommen und Verwendung', p.27. 


\begin{tabular}{cccc}
\multicolumn{2}{c}{ Number } & Places & Staff \\
1935 & 1,061 & 42,443 & 1,878 \\
1936 & 1,935 & 86,269 & 3,557 \\
1937 & 3,501 & 153,477 & 6,204 \\
1938 & 5,216 & 238,054 & 9,799 \\
1939 & 8,122 & 374,516 & 16,219 \\
194010,020 & 466,888 & 20,677 \\
1941 & 14,828 & 689,154 & 35,835
\end{tabular}

However, it certainly seems that from 1937 or thereabouts the NSV was beginning to suffer seriously the effects of shortages of enough trained personnel. At the end of the summer of 1937, after the Harvest Kindergartens had ceased to operate, it was necessary to direct all senior kindergarten staff who might be set to administrative work in offices at this time instead to work in these areas which were severely short of specialist staff. ${ }^{2}$ Not only that, but Hilgenfeldt was concerned to warn his staff that they could expect shortages again in the following year (1938) in the Harvest Kindergartens. ${ }^{3}$ However, these worries were later offset to some extent by the NSV practice of paying its full-time staff above the going rate, something the state officials were to deplore in 1941 . During the war, however, a serious shortage of NS-Volkspflegerinnen led to the shortening of existing courses so that enough trained

1. Ibid.

2. BA, NS 22/747, Hilgenfeldt to all local NSV offices, 2nd September 1937.

3. Ibid. 
personnel could take up a position sooner. ${ }^{1}$ A serious criticism of the NSV's staffing policies was given by Fiehler in 1941 when he raised doubts about the NSV's manner, and the lengths to which it would go in order to find enough staff for its own kindergartens. 2

However, these particular problems were by no means the more important ones with regard to the NSV's venture into the area of pre-school education, for it would find before the war that in some of the larger cities, such as Berlin and Munich, it would be extremely difficult, though by no means impossible, to set up its own kindergarten facilities. This is to say that the provision of NSV kindergartens as well as the other forms of NSV child and youth care, could hardly be described as a straightforward pre-war contribution to existing child and youth care in Germany. ${ }^{3}$ On the contrary, the NSV's new venture was a strong indication that pre-school education and welfare care for small children would eventually come under the control of the NSV. This area of child welfare would largely be given over to the NSV from about 1941, but the diminution of the state's participation would begin before the war began. However, state objections to NSV kindergartens which were offered hardly made the same impact as they did with regard to the provision of youth welare itself. In any case the NSV, as far as the provision of Party welfare was concerned, did not have to vie with

1. BS, NS/37ii/1010, 'Rundschreiben Nr. 91/43', 28th May 1943.

2. BA, NS $25 / 1158$, Fiehler to Bormann, 'Ubernahme neuer Kindertagestatten durch die Hauptstadt der Bewegung', 18th July 1941, report on the Munich kindergartens.

3. See correspondence between Hilgenfeldt and the Berlin state welfare offices, in 1936 and 1938; BA, R36/962, December and January 1936/37; BA, R36/1002, May 1938. 
the $\mathrm{HJ}$ for a share of the work with very small children, for the responsibility for these pre-school ages lay with the NSV itself. it was for this reason above all that the state officials viewed with resignation rather than surprise the ever-increasing participation of the NSV in the work of kindergarten care, for they knew only too well how determined the NSV could be in its arrangements over the insertion of 'zusåtzliccheór additional welfare, which was less an extra set of facilities than a continuing threat of future replacement of existing state welfare. ${ }^{l}$

In Berlin in 1936, three NSV kindergartens had been put up and there were another eleven planned, which would be erected at a later date. $^{2}$ However, these (and the prospect of further) NSV kindergartens were creating several problems for the existing Berlin state kindergartens through the promotion of particular policies of the Party's welfare organisation at this time. A really serious conflict had emerged between Hilgenfeldt and Spiewock and they had been conducting a series of arguments by letter over the activities of the NSV. ${ }^{3}$ Not only were state officials, and Spiewock in particular, being expected to view calmly the idea of the proposed new NSV facilities which would be set up in the districts of Wedding, Kreuzberg and Neukblln, but they were, in addition, having to suffer the existence of Party kindergartens which were openly operating as

1. BA, NS25/1158 'Die Errichtung von Kindertagestatten durch die Stadt Mannheim', Karlsruhe, 12th March 1940; BA, R36/962, Spiewock to Stadtpräsident, Berlin, letter of 7 th January 1937.

2. $B A, R 36 / 962$, Hilgenfeldt to Dr. Lippert, letter of 7th December 1936, p.2.

3. Ibid., Spiewock to Stadtpräsident, Berlin, letter of 7 th January 1937. 
rivals to the nearby state facilities. There is good reason to believe the accusation that the NSV kindergartens had been set up on purpose in close proximity to the existing state kindergartens in the areas in question, but that they were offering what amounted to free accommodation for children in these. This unfair and competitive action was seen reasonably enough as only one more sign of an NSV intention to replace the state's own arrangements with Party ones. Not surprisingly, parents had come forward to enquire if the state officials were also intending to offer free facilities, for if not, then they would seriously consider transferring their children to the NSV. A specious claim that no wish to offer 'free' places was intended through the practice of asking parents to offer to pay what they felt able to was offered to 'prove' that a donation was an equally effective method of payment as any other. State officials, the NSV argued, should not see a donation as an opportunity for non-payment. Nor as a method of 'free' entry to NSV kindergartens, for in fact the opportunity for a freely given donation had raised 'quite a substantial amount', and moreover, such a method ensured that those who could not pay the required charge would not be excluded from such care. Evidently the state charged (and intended that the NSV should also charge) from 0.10 to 2.50 marks according to family income; this the NSV merely ignored. ${ }^{l}$ There is little reason to doubt that this was a competitive practice on the part of the NSV as the state officials believed, the state welfare offices had

1. Ibid., 'Der Oberburgermeister Landes - Wohlfahrts-und Jugendamt Berlin, 'Personalvermehrung in Krippen, Kindergarten und Horten', September 1936; Ibid., 'Beitrage fur die Kinder in den Tagesstatten von Vereinen, die stadtische Zuschsusse erhalten, und die Tagestatten der NSV', 12th September 1936. 
attempted to make it clear that no-one would be charged more than they could afford; even though facilities were not free, a charge of 0.10 marks may have been regarded by many as a reasonable one until the NSV had introduced its own particular form of 'fair' charges for all. I It certainly seems that Hilgenfeldt had no intention whatsoever of changing this particular policy and it seems to have been carried through in other NSV kindergarten facilities throughout the country, even though no other state official, so far as can be discovered, made reference to this. The most galling situation for the Berlin Landesjugendamt at the end of 1936 was that many parents were beginning to question the right of the state to make charges for these facilities, and indeed a 'ganze Reihe von Eltern' had been bothering the Berlin officials with requests that they adopt the same policy. ${ }^{2}$ Such a situation certainly had its more serious side, for it called into question the payment of the NSV state subsidy which, strictly speaking, the NSV was putting into jeopardy through its willingness to ignore the existing regulations. However, Spiewock's attempt to threaten the NSV at this time (1936) with non-payment of the subsidy for its kindergartens in Ross Strasse, Garten Strasse and Am Friedrichshain (RM 769.29, RM 658.0 and RM 1,589 respectively) came to nothing. ${ }^{3}$ This matter should not be confused however with the attempt to reduce the whole NSV subsidy in $1936 .{ }^{4}$

1. Ibid.

2. BA, R 36/962, Spiewock to Stadtpräsident, Berlin, letter of 7 th January 1937.

3. Ibid.

4. See Chapter Two. 
At the end of 1937 and into the spring of 1938, a series of problems arose yet again over the NSV's activities in the city when it became known that it was about to take over entirely the Berliner Hauptverein fUr Kindertagestatten which had been set up in 1935 to act as an umbrella organisation for some of the previously existing private kindergartens in Berlin. ${ }^{l}$ This included the kindergartens of the former paritatischer Wohlfahrtsverband which had been dissolved, and whose kindergartens in other areas had been taken over entirely by the NSV. Most importantly, the Berliner Hauptverein, run now by state officials, also administered and controlled the subsidies which were paid out by the state.

The kindergartens of the 'Berliner Frobelverein' received 33,230 marks, and the Verein Volkskindergärten, also in Berlin, received 25,290 marks per annum. ${ }^{2}$ Nevertheless, there seems never to have been any real possibility that the Berlin Landesjugendamt could have retained its own management of the Berliner Hauptverein once the NSV had set in motion the mechanisms to assume full responsibility. However, Spiewock was most concerned at this time to make a firm effort to dissuade Hilgenfeldt from divorcing the running of the Berliner Hauptverein entirely from the state, indeed he hoped that he could persuade the NSV to operate a joint control of this umbrella organisation. ${ }^{3}$ An offer to allow the NSV to run the Verein while the state would retain some say in the control and management of the

1. BA, R 36/1001, Spiewock to Hilgenfeldt, letter of 17 th May 1938 .

2. $B A, R 36 / 964$, 'Aufwendungen fur Vereine auf dem Gebiete der Wohlfahrt', 1936, pp. 281-286.

3. BA, R36/1001, 'Denkschrift', Spiewock to Hilgenfeldt, May 1938, p. 5 . 
subsidies and of bureaucratic arrangements met with a negative response, however. ${ }^{l}$ The Gauamtsleiter of the NSV in Berlin, (who had taken over from Spiewock in 1936), stuck to his original emphasis of allowing the Verein to go into liquidation, a process which was duly completed on the 2nd April 1938. ${ }^{2}$ This meant that the NSV itself would be able to take on the running of the kindergartens which had come under the control of the Verein. Certainly, Spiewock had known from the end of 1936 that the NSV was extremely interested in the Berliner Hauptverein and its kindergartens and at this time he warned that the NSV was looking forward to taking on this responsibility. ${ }^{3}$ Spiewock regarded this matter as blatant ingratitude for the help he had earlier given in transferring some private kindergartens (not owned by the confessional agencies) to the NSV, which seems to have amounted to approximately 58 out of the existing 471 subsidised (including state-owned) kindergartens existing in the city. The NSV by this time (1938) had set up 17 of its own facilities, ${ }^{4}$ and the confessional agencies of Caritas and Innere Mission owned and operated 183 of the total number of private kindergartens in the city. From this time, therefore, the 32 former paritatische kindergartens and a few other private kindergartens would now (with their subsidies) come under the control of the NSV. ${ }^{5}$ There is no

1. Ibid., Gauamtsleiter, NSV Berlin, to Spiewock, letter of lst March 1938.

2. Ibid., 'Berliner Hauptverein fur Kindertagesstutten e.V., Liquidator to Spiewock', letter of 2nd May 1938.

3. BA, R36/962, Spiewock to Stadtprassident, Berlin, letter of 7th January 1937.

4. BA, R36/1001, 'Denkschrift' Spiewock to Hilgenfeldt, May 1938 , p.5.

5. Ibid. 
doubt whatsoever that Hilgenfeldt and Spiewock had come into serious conflict at this time which the NSV's intended control over the administration of the Berliner Hauptverein threw into strong relief. The NSV had proposed that no state auditing of NSV finances in Berlin should be undertaken even after the assumption of control of the Berliner Hauptverein. This NSV claim angered Spiewock greatly given that he felt himself to be constrained by his legal responsibilities to make an examination of the NSV finances in Berlin ${ }^{l}$ now that the NSV would be looking after the affairs of the former umbrella organištion and its existing kindergartens. It certainly seems as though the prospect of the NSV being in direct charge of state funds in respect of other private facilities put Spiewock into an impossible position as a leading state official. For the NSV would be seen to be administering state funds in respect of another party, but without the need to have state supervision of its financial affairs. This is not to say that the NSV had not done this type of thing before, which Spiewock himself admitted, for the NSV had been allowed to take on the full responsibility for the funds of the confessional 'Bahnhofsmission' in Berlin, 'in spite of strong opposition from the charitable agencies'. Other confessional welfare measures too were supervised in this manner by the NSV, and this included such measures as the churches, Hauskrankenpflege/Hauspflege? Perhaps Spiewock had entertained the hope that the creation of the Berliner Hauptverein would render unnecessary the NSV takeover of more private kindergartens than seems to have been the intention on

1. BA, R36/1001, Spiewock to Hilgenfeldt, letter of 17 th May 1938.

2. Ibid. 
the part of state officials in the city. Certainly, in Munich

a pre-emptive measure of Fiehler's had prevented the NSV from gaining control of a majority of the private kindergartens there for these had been already taken over by the state. ${ }^{l}$ But it seems to have been a difficult legal operation to carry through apart from other considerations, and Spiewock was not able at this time to fend off the extensive NSV incursion into the Berlin private kindergarten sector. ${ }^{2}$ Possibly the main problem for the state officials was, as Hilgenfeldt had already pointed out, that the NSV, though a frei agency, was nevertheless not like other private agencies, and was supposed to be given, whether grudgingly or not, every support by the state officials who were expected to regard the Party agency in a 'favourable' light and give it assistance when possible, and this included helping in an effective transfer of existing private facilities for welfare to the Party agency. ${ }^{3}$ However, by 1938 , the clear impression is given that the Hitler Youth itself had managed to find a good working arrangement with the Berlin state welfare offices, and it was certainly a matter of some regret to Spiewock that he had failed similarly to arrange for a good working relationship with the NSV. ${ }^{4}$ The $\mathrm{HJ}$ and the Berlin Landes-Wohlfahrts-und-Jugendamt had arranged for a working compromise in that the state owned Homes, sports arenas and youth hostels being used by the $\mathrm{HJ}$ would continue to be so owned and

1. BA, NS 25/1158, Fiehler to Bormann, report/Munich/Kindergartens, 18th July 1941 .

2. Ibid., Bormann to Fiehler, 'Ubernahme neuer Kindertagest durch die Haupstadt der Bewegung', letter of 16th August 1941.

3. Ibid.

4. BA, R36/1001, 'Denkschrift' Spiewock to Hilgenfeldt, May 1935, p. 14 . 
administered, but that the $\mathrm{HJ}$ itself would take on all responsibility for the activities being organised. The state would, in other words, not lose its responsibility with regard to their administration. ${ }^{l}$ The $\mathrm{HJ}$ would of course be entirely responsible for all matters to do with the training and education being carried out in these various sports halls and other facilities. Interference of the kind which the NSV feared, namely that the state would have access to administrative details such as finances, which the NSV could not relinquish or wish to reveal, came to spoil the possibility of the Party and state agencies from reaching a compromise at this time. It may also be true to say that the state welfare offices usually managed to reach agreements with the HJ whenever that was necessary and far more easily than they had ever been able to do with the NSV, and, in addition, in a majority of cases. $^{2}$ Above all, the NSV wished to keep its own finances an entirely secret matter. The difficulty in finding any evidence of NSV finances is testimony to its success in this respect.

To a very large extent the outbreak of war came as a solution to NSV developments in the participation of kindergarten work throughout Germany. From this time, new agreements would ensure that the NSV would be allowed to take on the full responsibility for the new kindergartens which would be set up in the expectation of an increased participation of women in war work, and in other areas as well. 3 This meant that these state officials who had resisted as far

1. Ibid.

2. Ibid.

3. BA, NSD 30/4a, NS-Volksdienst, December 1943, p.161; BA, NS 25/1158,' 'Entwurf', 'Zusammenarbeit der Gemeinden/. NSV, zur Forderung der Kindertagesstatten, 1940 . 
as they could an increased NSV participation, would find that this was no longer possible from about 1940. Hilgenfeldt would find that he had the full support of Bormann, and others such as the Education Minister in Munchen/Oberbayern, which would have a most important effect on the NSV's activities in the city of Munich. ${ }^{1}$ It certainly seems as though up to 1941 , the state officials in Munich, with the support of Fiehler, had successfully prevented any real NSV presence there with regard to kindergarten work at least. ${ }^{2}$ However, by 1938 , the high percentage of NSV participation in the work of Jugendhilfe in the Gau Munchen/Oberbayern itself (88.6\%) points to quite another type of development, so that the two separate types of youth and child care cannot be held to be similar from the point of view of participation in certain substantive areas of welfare. ${ }^{3}$

Fiehler's reaction to new guidelines of July 1941 (which would ensure the future strong participation of the NSYwithin the city, given that the NSV would be officially allowed to organise all new kindergarten facilities there and elsewhere in Germany), was to make an argument for the continuation of state organised facilities, including a state-arranged organistion of the new facilities. In a report to Bormann he showed how utterly against NSV kindergartens and, indeed, the NSV in general, he was at this time. ${ }^{4}$ It is absolutely clear that a promised interference by the NSV into the Munich kindergarten arrangements was greeted with deep dismay when it became known that the new Regulations of 1941 would support this. A

1. BA, NS 25/1158, Bormann to Fiehler, Munich/kindergartens, 16th August 1941.

2. Ibid., Fiehler to Bormann, report/Munich/kindergartens, 18th July 1941.

3. BA, NSD 30/11, Informationsdienst, July 1939.

4. BA, NS 25/1158, Fiehler to Bormann report/Munich/ kindergartens, 18th July 1941. 
spirited defence of the existing arrangements of state kindergartens was made in his long report - it can hardly be called a letter - to Bormann in July $1941 .^{1}$ Fiehler gave what can be seen as a strong support of the provisions of the state which had carried out its duties effectively and responsibly. In an effort further to show how suitable the state arrangements were in the participation of Nazi welfare measures, Fiehler stressed that in Munich, at least, church facilities had never been strongly represented - even those of the Catholic church - due to the tendency in Munich to offer an extensive, but state-organised, kindergarten welfare provision. ${ }^{2}$ Indeed the first state kindergartens in Munich had been put into operation as early as 1868 , so that by 1907 , there already existed 20 kindergartens belonging to state welfare. This meant that by 1913 , it had been necessary to erect a training school for kindergarten teachers in the city. ${ }^{3}$ However, a long history lesson from Fiehler was not appreciated by Bormann who answered only briefly, and negatively. Bormann seemed not to be impressed by the fact that after 1933, the state had assumed control of a majority of the existing church kindergartens (or other 'unacceptable' arrangements). Neither was Bormann impressed by the fact that National Socialist principles were being applied in a 'unified' manner within Munich regarding this particularly important pre-school educational measure. ${ }^{4}$ Fiehler's trusted colleague Stadtschulrat Bauer was in charge of all the work being undertaken in the Munich kindergartens
1. Ibid.
2. Ibid.
3. Ibid.
4. Ibid. 
(and schools), and he was of course himself a trusted member of the Party. ${ }^{l}$ In addition Fiehler wanted Bormann to know how the Stadtverwaltung Munchen had paid out very considerable sums of money for all pre-school facilities and therefore had a very strong stake in such work. For example, in the financial year 1940/41 the cost of the pre-school programme in the city had amounted to RM $1,508,385 .^{2}$ To this figure could be added the sum of RM 80,000 which the city had given as a contribution to the costs of children's meals. It was also pointed out that only one twentieth of this large sum had been allowed from other state resources and he (Fiehler) was unable to see how the NSV would itself assume such a responsibility should that become necessary. ${ }^{3}$ However, this was to jump the gun, for the 1941 guidelines had not instructed that the NSV assume control over all state kindergartens, only over the new ones which were intended to be built at this time. Interestingly enough, many state officials seemed to see this new development as the thin end of the wedge, promising as it did the growing strength of the NSV in this particular welfare area. ${ }^{4}$ Fiehler's reasonable request that the new arrangements not be allowed to disturb the city's administrative processes, as they undoubtedly would, made it clear that he was attempting to put every possible reason forward for not implementing the new arrangements. 5

From the point of view of maintaining the 'unity of the admin-

1. Ibid.

2. Ibid.

3. Ibid.

4. Ibid.

5. Ibid. 
istrative arrangements' it was obvious, he hoped to show, that it would be necessary to leave the state completely in control of the new and also existing, kindergartens and nurseries in Munich. These amounted at this time (1941) to:

108 Kindergartens

118 Kinderhbrte

226 Kindertagestatten ${ }^{1}$

But this was a digression which had little to do with the matter in hand and Bormann did not question the fact that Munich kindergartens were well run and came under a Hurteinspektor whose duty it was to ensure that Munich's facilities were being properly run. Most importantly, however, all pre-school facilities came under the unified control of the Stadtjugendamt. Unfortunately, Fiehler did not give the numbers of remaining church or other private facilities or even (it would seem) the few NSV arrangements which existed at this time. ${ }^{2}$ Certainly it was clear that anNSV leadership over new kindergartens would disturb such a unity of procedure, both of control and of leadership, but this did not seem to be a matter which Wagner, the Education Minister, or Bormann himself, were concerned about. It seems obvious that neither man had such a high opinion of the Munich kindergarten administrative arrangements as Fiehler himself. From these several arguments of Fiehler's it seems clear that he had sought earlier, and with some considerable success to pre-empt an NSV development in the city's nursery arrangements for a few years at least. There seems no reason to doubt that, as he says, a new set of administrative arrangements would have to be
1. Ibid.
2. Ibid. 
created in Munich in order to accommodate new NSV kindergarten arrangements. $^{1}$ The whole problematic issue of a double supply of Nazi welfare facilities was raised by Fiehler who quite justifiably wondered (though not to Bormann at this time) why the NSV should be in a better position than he and his trusted staff to provide ideologically acceptable social welfare measures. ${ }^{2}$ Had an answer to this question readily presented itself, then many of the problems of the German welfare system from 1933 would have been solved over. night. 3 No such solution would be forthcoming, however, and the city of Munich's kindergarten facilities would be, albeit briefly, drawn into the Party/state struggle over jurisdictional issues. However, given that the further development of pre-school measures would now lie within the scope of the Party's welfare organisation a development hastened by the outbreak of war - many problems which had arisen in peace time would be circumvented. ${ }^{4}$ However, it must be stressed that NSV Jugendhilfe measures did not always receive quite such a strong thrust of support from the Party leadership, and the NSV would find that it would remain as a more difficult nut to crack in some areas, even in time of war. ${ }^{5}$ In the summer of 1941 it was made clear to powerful state officials, including Fiehler himself, that the thrust of child-care and kindergarten care would favour the NSV and it seems that they would have to adjust to this development as

\section{Ibid.}

2. Ibid.

3. See Chapters Two and Five.

4. BA, NS $25 / 1158$, Bormann to Fiehler, Munich/kindergartens, 16th August 1941 .

5. See Chapter Seven. 
best they could. Fiehler's report, which outlined in great detail the absolutely impeccable credentials of his own staff, and those of the state welfare officials who were in charge of supervising the kindergartens of the city, pointed out that the same thing could not be said of the NSV. ${ }^{l}$ Whereas the leading officials of the Jugendamt were all well-known National Socialists, ${ }_{h}^{\text {and }}$ all the staff employed in the state kindergartens were proven beyond doubt to be 'politically reliable', such a claim could not be made for NSV kindergarten personnel. On the contrary, though he was not in a position to know precisely how the NSV chose their staff, it was 'personally known to him' that some of the former applicants for state positions in kindergartens who had been trained in the confessional schools, and who had been turned down by the state agency, had themselves been taken on by the NSV. This meant that persons who had, 'only shortly before' been working within the framework of the church's charitable emphasis were, 'now working for the NSV'. This was a serious allegation, given that the NSV had long since asserted that the philosophical bent of its own measures rejected absolutely the idea of 'charity', but it may have been an entirely accurate one. In Baden at the end of 1942, it was clear that the NSV was still employing 'confessional personnel'.2 In Mannheim too it was known that the NSV had been forced to retain confessional staff in the kindergartens which they had recently taken over. ${ }^{3}$ However, as Bormann must have known, he could trust Hermann Althaus and

1. BA, NS 25/1158, Fiehler to Bormann, report/Munich/ kindergartens, 18th July 1941.

2. Grill, The Nazi Movement, p.601.

3. BA, NS 25/1158, report to DGT, 'Die Errichtung von Kindertagestatten durch die Stadt Mannheim', 12th March 1940. 
Hilgenfeldt to make changes whenever that became possible and there seem to have been no worries on that score especially as Bormann must have been aware of the views of Althaus who, in 1941, tried to raise support in order to exclude the churches entirely from the whole field of welfare as it was organised for the young. ${ }^{1}$ As Bormann's short reply to Fiehler shows, he wished to continue with the guidelines of 1941 as set out, and this was with the agreement of Wagner who strongly wished to see the NSV take on the new responsibilities. There really was no possibility that Fiehler would be successful in his attempt to halt NSV developments in his own city, even though his defence of the state kindergartens was almost as desperate as the one he would become to prepare for the situation at the end of the war when he was concerned to protect the Brown House, at all costs, from the Allied advance. There is little doubt about the disparate development of social policy as it relates to social welfare during the early part of the war, an examination of the period up to 1941 reveals this to be the case. However, from 1942 there seemed to develop an attempt to coordinate social policies, at least for the provision of welfare for very young children, and less successfully perhaps, for older juveniles. From 1941, day-care facilities would be organised by the NSV in such a way as to provide a strong National Socialist emphasis which at the same time aimed to use the latest developments in ideas about the nutrition of children and the development of the 'normal child'. 2

1. BA, NS 25/1233, Althaus to Axmann, letter of 20 th November 1940.

2. BA, NSD 30/4a, NS-Volksdienst, December 1940, pp. 175-176. BA, NS 37ii/1031, 'Stoffplan-Kindergärtnerinnen', see Section C,'Entwicklung und Pflege des Kindes', p.14. 
That the future development of the NSV's kindergarten programme from 1941 was firmly established, was recognised at the time by a report from the Gau Schwaben which acknowledged the recent advances of the NSV in such work by a recognition of the NSV's highly successful 'Vormarsch' which the example of Munich had shown. This particular report saw the now strongly based developments of the NSV in the most favourable light and pointed out that, without doubt, the NSV kindergartens were organised in the 'most modern sense' using the best methods and that the NSV was, without doubt, better able to carry out such pre-school provisions than the Gemeinden or local government facilities. $^{l}$ It was also pointed out however that the funding of the NSV kindergartens, which were partly or even completely financed by local government funds, had to be regularised in some way and that the NSV itself should take on the funding of their own facilities as soon as possible. The Gemeinden were faced at this time with a most complicated job, for it was a time-wasting and a difficult task to administer subsidies because of their complex nature. Indeed, another way of funding such welfare would need to be found. ${ }^{2}$

While the guidelines of 1941 firmly set the development of the NSV kindergarten programme on its path, an earlier one of late 1939 had begun this process so that in Karlsruhe in 1940 there had emerged worries about whether the new kindergartens which had been planned for the city earlier were now going to be run by the state,

1. BA, NS 25/1158, 'Tatigkeitsbericht' Gau Schwaben, report of July/August $1940 / 41$.

2. Ibid., 'Die Errichtung von Kindertagestatten', Monnheim, 12th March 1940. 
or by the NSV. ${ }^{1}$ Karlsruhe had for long organised a comprehensive provision of pre-school facilities which took in various categories of children, including those in need of extra care and attention as well as those whose mothers were fully employed. ${ }^{2}$ It was felt that at the time (March 1940) the earlier plans lay outside the 1939 agreements, for the new kindergartens had been originally planned as early as 1938. For this reason it was believed that the Hilgenfeldt Fiehler agreements of 1939 did not come into question. It certainly seems as though these particular 'agreements', a copy of which has not been discovered, were a preliminary set of proposals which were less binding than the later one of 1941. It may be that Fiehler had made the agreements in the vain hope that a further set of of new proposals would not arise which would disturb the Munich kindergarten facilities, or that he could somehow circumvent them, as his letter to Bormann in 1941 shows. $^{3}$ It seems however that Hilgenfeldt had been able to persuade Bormann that another, perhaps firmer set of guidelines was required. Undoubtedly however, there existed a strong move away from state to Party facilities for kindergartens from the time of the outbreak of war, which was utterly decisive for the Party organisation's own development within the whole field of child care. However, this does not mean that the NSV would begin to solve all its problems, for the difficulty of finding sufficient staff would remain. Officials in Karlsruhe during 1940 had realised that the NSV was having problems over its staffing levels 'as usual', and it was noted that in 'dozens of cases' in NSV kindergartens taken over from

1. Ibid.

2. Ibid.

3. BA, NS $25 / 1158$, Fiehler to Bormann, report/Munich/ kindergartens, 18th July 1941. 
the confessional agencies, nurses of the Catholic and the Evangelical orders were still active in these and that ministers of religion could be seen in these kindergartens going freely back and forth. With regard to such kindergartens, it was pointed out, one could hardly talk of a Nationalsozialistische Erziehungstatte. ${ }^{1}$ But it was acknowledged that the NSV could hardly be expected to take over, and run entirely, the 580 confessional kindergartens which still existed in the Gau Baden. As J.H. Grill has pointed out in his study of Baden, as late as October 1943, confessional kindergartens were still flourishing in the Gau. ${ }^{2}$ But this meant less than it seems, for Baden had made arrangements similar to those made in Gau Sachsen in 1940, which would arrange for the transfer of all its confessional kindergartens to the NSV in relation to all senior staff which meant that all decision-making power was transferred, and the confessional staff would no longer be allowed to undertake any decision-making roles. But it may be questioned how far the NSV could exclude church influence if a majority of the subordinate kindergarten staff also remained. But these policies were conceived in a step-by-step manner given the sheer impossibility of replacing all confessional kindergarten staff by those of the NSV overnight. 3 Nevertheless, an agreement with the NSV to take on the running of confessional kindergartens carried with it the underlying fear, on the part of state officials, that they were allowing the NSV a potential foothold in the state sphere at the same time. This certainly seems to have

1. Ibid., 'Die Errichtung von Kindertagestatten', Mannheim, 12th March 1940.

2. Grill, The Nazi Movement, p.603.

3. BA, NS 25/1158, Wohlfahrtsamt Stuttgart, 'Die Kindergarten der NSV in Stuttgart: Entwicklung der Einrichtungen', report of 1942 . 
been the case in 1940 in Sachsen for great pains were taken to see that agreements being drawn up between the NSV and the state officials did not allow for a future take-over of the state run kindergartens of the Gemeinden as well. Officials were very seriously concerned whether the agreements could open up the possibility of a swift take-over of all the Gemeinde kindergartens, 'on the spot'. ${ }^{1}$ The agreement under scrutiny did not openly set out such an eventuality, but it was feared that a clever (or cunning) interpretation by an NSV offical could have made such a situation possible or even very likely. For this reason, in discussions between the DGT, the Saxon Minister of the Interior and the NSV, it had been expressly emphasised that the NSV should not then, nor in the future, disturb the running of the kindergartens of the Gemeinde. ${ }^{2}$ This clarification of the agreements in question, the Order of the 2nd December 1940, seems to have set at rest the minds of the state officials in Sachsen at that time.

However, the NSV did not always operate within such a hostile and suspicious environment with regard to the allocation of the confessional kindergartens and their future. For example, in Gau Hessen-Nassau the Gauleitung was quite happy to see the NSV make promises to take over all the existing confessional kindergartens, indeed it also asked that the NSV to take on the running of 20 state kindergartens in the city of Frankfurt, though the state would continue to administer them while the NSV would take on the responsibility for the running of the facilities. ${ }^{3}$

1. BA, NS25/1158, to DGT, 'Kindertagestatten', discussions of the new regulations, 28th February 1941.

2. Ibid., see letter from Amt fur Kommunalpolitik, Dresden, 8 th March 1941.

3. Ibid., Gauleitung Hessen-Nassau to Frick, letter of 16th September 1941. 
At this time in Hessen-Nassau, it had been decided that pre-school facilities could be left to the NSV where necessary, and in any case, state officials had seen the need to ask for NSV help in the light of increased shortages of staff due to the war. ${ }^{l}$ On this subject, Bormann seems to have taken the line that where no very serious difficulties existed, the state should hand over to the NSV where the war itself, through shortages, had caused many problems to arise in the kindergartens of the Gemeinden.

From 1941, Bormann saw the development of pre-school education entirely from the point of view of a Party take-over and his attitude in the summer of 1941 certainly showed this, given his refusal to contemplate a request virtually to exclude the NSV in Munich from new kindergarten arrangements. ${ }^{2}$

From 1942, these developments were going on apace at the same time as many new harvest kindergartens were being set up in the country area of Ganserndorf. In this area 11 Gemeinden were in the process of setting up new Harvest Kindergartens since so many mothers were failing to take on work because of the lack of kindergarten facilities there. ${ }^{3}$ These kindergartens would be available to mothers who would find that all or half of the cost would be paid by their employers, if they wished to take advantage of them. ${ }^{4}$ The whole question of the willingness of women to make use of these facilities however is one which perhaps the NSV had not fully considered, for

1. Ibid.

2. Ibid., Bormann to Fiehler, Munich/Kindergartens, 16th August 1941.

3. Ibid., 'an alle Herren Burgermeister des Landkreises Gänserndorf, NS-Kindergärten', 30th March 1942.

4. Winkler, Frauenarbeit, see pp.55-66. 
many woman seemed reluctant to return to work in war-time. In its anxiety to create an empire for itself, the NSV certainly neglected to consider the opinion of the potential consumers of such new facilities. And it certainly seems that the NSV's own kindergartens were usually short of staff. Even in those kindergartens which were taken over and run by the NSV, shortages of staff ensured the continued participation of confessional nurses so that in these, especially, the input of the NSV was entirely superfluous and hardly helpful; indeed the running of these particular kindergartens would have been best left to the original staff who had been working in them. ${ }^{l}$ At least Fiehler in Munich was able to show that he did not make the same 'mistake' by allowing confessional staff to be taken into his state kindergartens, or so he claimed in 194l. Most importantly, the confessional kindergartens would remain to be popular and they would only be replaced gradually by the NSV as the example of Berlin shows. Indeed an NSV assumption of control was in many cases only a partial one, both there and in Stuttgart. it seems that where state officials were keen to allow the NSV to take over existing church kindergartens, then this would take place. However, the opposite was also true: if the existing confessional arrangements were not to be disturbed, according to the wishes of leading state officials, then the NSV would find it far more difficult to obtain its goal. ${ }^{2}$ It must be remembered that state officials frequently saw an NSV takeover of confessional arrangements as the first step in the takeover of the state facilities as well,

1. BA, NS 25/1158, 'Die Errichtung von Kindertagestatten', 12th March 1940.

2. BA, R36/1001, DGT to RMdI, report to Ministerialdirektor Dr. Surén, 'Zusammenarbeit zwischen yffentlicher und freier Wohlfahrtspflege', 27th July 1938. 
and were therefore less enthusiastic about the exclusion of church facilities than they might have been in the first place. But the move was toward NSV kindergartens or, NSV-run kindergartens; this was something which the state officials knew about from 1941, and it would be written into the Order of Hitler of 1944 which outlined the responsibilities of the NSV for the 'future'. Hitler intended that all the various categories of kindergarten should remain. ${ }^{l}$ It was also shown that the NSV should continue to participate in this work as before in relation only to the 'worthy' categories of family, whose children would be sent to the NSV facilities. For the Hitler Order did not envisage a reduction of the distinctions between 'worthy' and 'unworthy' families; on the contrary, it provided a firm written confirmation of such work and ensured its continuation, both at that time, and, as far as the leadership were concerned (and Bormann in particular) for the future as well. ${ }^{2}$

\section{NS-Schwesternschaft}

The NSV did not only become involved in health care through their work with children in the kindergartens and in other ways through holiday schemes for children and adults. Indeed, the NSV was charged in 1934 with organising the arrangements for a Nazi sisterhood of nurses (NS-Schwesternschaft). ${ }^{3}$ This new organisation of nurses was announced on 28 th March 1934 with the additional information that the existing organisations of nurses of the

1. BA, R36/963, 'Verfugung $11 / 44$ ', FUhrerhauptquartier , 22nd August 1944.

2. Ibid.

3. BA, NS 37ii/1039, 'Anordnung $\mathrm{Nr} 1$ ', instructions of 28th March 1934. 
'Rote Hakenreuzschwestern', and the 'Braune Schwestern' had been dissolved on the 15th January 1934 and would now be included within the new NSV order of nursing sisters. The new NSV order was, it seems, widely known as the 'Brown Sisters' and, perhaps less frequently, as the 'Blue Sisters', depending upon whether they were active in nurseries and kindergartens (Blue) or in hospitals, and in the Community Health stations of the NSV (Brown) ${ }^{l}$ Generally speaking the nurses of the NS-Schwesternschaft were occupied in the Gemeindepflegestationen of the NSV which were also set up in 1934, and the numbers of these would rise year by year until they amounted to 5,717 in 1941 while the number of NS-nurses came to 5,891. But this was not nearly enough, for in 1943 when the numbers of NS-nurses stood at 7,000 , it was stressed that there needed to be 30,000 community-care nurses available. Indeed, the intention to supply a better hospital nursing service generally included the calculation that it should be increased by $10 \%$ at the latest by 1950, (and by $20 \%$ by 1960) to accommodate the needs of an ageing population. ${ }^{2}$ The NSV Community Health stations were available for visits by the local population or, on the other hand, they provided a home visiting service by nurses whereby health-care for the community was carried out by trained senior nurses who might in addition be able to stand in for busy doctors. It seems that the NSV sisterhood of nurses (hereafter NS-nurses) would consist of an organisation of both trained and trainee nurses who would see the duties of the nurse from the point

1. Ibid.

2. BA, NS 26/261, 'Aufkommen und Verwendung', p.28; BA, NSD 30/4a, NS-Volksdienst December 1943, see Section 3, 'Gemeindepflege', p.174; BA, NS 37ii/1010, 'Rundschreiben $\mathrm{Nr} .31 / 43$ ', 18th February 1943. 
of view of the National Socialist 'spirit of service for others'. 1

By the 16th April 1934, the NSV Gauamtsleiter of the department for Organisation in the NSV head office in Berlin was asked to report on the existing numbers of hospitals , clinics, Mothers' Homes, community nursing stations, Kreis social welfare stations and Children's Homes. At the same time he was asked to report on the numbers of beds available for patients in hospitals. This list suggests that an attempt would be made to coordinate information on available health care in order to see how the measures of the NSV could best be organised in relation to its newest venture, the provision of community health care. However, it seems that this particular new section like the sub-divisions of the NSV created in the light of the Four Year Plan, such as the Ernahrungshilfswerk, and possibly also the IB Hilfswerk, was subordinate to the main work of the NSV which revolved around the provision of welfare for women, juveniles and pre-school age children, as well as the annual charity scheme, the Winterhilfswerk/Kreigswinterhilfswerk. ${ }^{2}$ Indeed the danger of the NSV spreading itself too thinly within a growing variety of welfare schemes reflected the propensity of the NSV leadership to take on any and every chance further to involve itself in the whole provision of Nazi welfare, from handing out quantities

1. Ibid.; BA, NS 37ii/1039, 'Anordnung $\mathrm{Nr} \mathrm{1';} \mathrm{'Anordnung} \mathrm{Nr} .7$ ', instructions 28th March; 1lth October 1934, the oath of the NS-Nurse read, 'Ich schwbre Adolf Hitler, meinem Fuhrer, unverbrUchliche Treue und Gehorsam. Ich verpflechte mich, an jedem Platz, an den Ich gestellte werde, meine Berufsaufgaben als nationalsozialistiche Schwester treu und gewissenhaft im Dienst der Volksgemeinschaft zu erfullen, so wahr mir Gott helfe!'

2. See Chapters Three and Five. 
of potatoes on a cold winter's day to advising a mother about the problems of a young adolescent. ${ }^{1}$ However, given the thrust of NSV policies and developments, every opportunity would be seized to take on more responsibility not only for the welfare but also for the health of the nation. A hugely ambitious organisation, the NSV had a wish to see itself being included in the work of health, as well as welfare guidance. There seem to have been a few problems arising at the time of the creation of the NS-nurses with the office for People's Health, which arguably would have been the more logical framework within which an order for Nazi nurses would be organised, but these were minor and it would be the NSV which would be expected to take on this particular duty. But the NS-nurses should be seen rather more in the form of a community-nurse service rather than as an organisation of hospital nurses per se. ${ }^{2}$ Membership of the NS Schwesternschaft was open to any German Volksgenossin who was a National Socialist 'by conviction' and who was under the age of 35 . The youngest NS nurse had to be over the age of nineteen before she could join. However, the lower age limit was given to be age 18 , in the NSV handbook, Schule fUr das Leben, ein Beruf in der NSV, which suggests that quite soon the NSV had decided to include more potential trainees, certainly by 1936 or thereabouts. ${ }^{3}$ Training for the Nazi sisterhood consisted of a two year spell in a hospital at the end of which the state examinations would be taken. The costs of the training were nil and those undertaking training received a

1. Ibid.

2. BA, NS 37ii/1040, 'Entwicklung der NS-Schwesternschaft', n.d. (?1943).

3. BA, NS 37ii/1039, 'Anordnung Nr 1', 28th March 1934; NSD 30/50, Schule fur das Leben, p.18. 
monthly sum of RM 15, to provide for small purchases; indeed it acted as 'pocket money' for the young women until a salary would be received. ${ }^{l}$ However, one pre-requisite for entrance to training as an NS nurse was the necessity of spending one year as an NSV Household Help. ${ }^{2}$ At the end of her training and at the very start of her nursing career, the NS nurse could expect to earn RM 175 per month. She would also receive a free uniform and additional social security coverage. Her career prospects seem to have been fairly good, and she could take up the post of:
1. Stationsschwester
2. Jungschwesternfuhrerin
3. Oberschwester
4. Oberin.

The numbers of NS-nurses from 1934 to 1941 was given by the NSV to be as follows:

\begin{tabular}{lrr} 
Year & Numbers & In Training \\
\cline { 2 - 3 } 31.12 .1934 & 1,001 & 396 \\
31.12 .1935 & 3,350 & 819 \\
31.12 .1936 & 4,685 & 1,391 \\
31.12 .1937 & 5,923 & 2,838 \\
31.12 .1938 & 7,498 & 3,858 \\
31.12 .1939 & 9,781 & 4,305 \\
31.12 .1940 & 11,614 & 3,841 \\
31.12 .1941 & 11,993 & \\
Ibid. & & \\
Ibid. & & \\
Ibid. & & \\
BA, NSD 30/51, Deine Arbeit, see 'Schwestern'.
\end{tabular}


It certainly seems that the NSV never had quite enough of these NS-nurses to go round and strenuous efforts were made to gain new recruits for the sisterhood. ${ }^{1}$ In 1938, a substantial publicity/ advertising campaign for the NS-nurses was undertaken in the months of January and February of that year. It was hoped that new recruits would be gained not only for the NS-nurses but also for the Schwesternschaft of the Red Cross and the Reichsbund der freien Schwestern und Pflegerinnen e.V. ${ }^{2}$ The propaganda material for this campaign was put together by the Rundfunkstelle of the department for Werbung und Schulung in the NSV offices in Berlin, and there would be broadcast a series of programmes lasting approximately fifteen minutes each, which would deal with the NS-nurses and their work from the point of view of a listener who might be interested in joining the sisterhood. ${ }^{3}$ The intention was to broadcast a set of items which were designed as Vorpropaganda und Beeinflussung, (introductory propaganda material) and programmes under this heading were put out one month before the recruitment drive in February. The first wave of programmes was meant to serve as a support and as an introduction to the drive. In January, some of the programmes would include such ideological/propaganda messages to the listeners as, 'Next to the vocation of 'mother', a female has no finer, more womanly, task than

1. BA, NS $22 / 747$, 'Arbeit der NSV', propaganda instructions, 'Rundfunkstelle des Amtes Werbung und Schulung, Hauptamt fur Volkswohlfahrt', 9th December 1937; BA, 37ii/1042, 'Werbefeldzug Schwesternschaft,Termine Januar-Februar 1938'.

2. BA, NS 22/747, 'Arbeit der NSV', see 'Die drei Schwesterngruppen: "Deutschen Schwesterndienst"'.

3. BA, NS37/1042, 'Werbefeldzug Schwesternschaft', Anlage, 'Terminplan'. 
the career of a nurse'.l The first programme would include a reportage from the Rudolf-Hess-Krankenhaus in Dresden (the first nurses' training school). Other programmes to follow would be given from the point of view of a diary of activities of 'Sister Else', which would give the listener the chance to learn about the daily round of an NS-nurse and what this was likely to entail. However, something on the free time of the nurse would be included also - no doubt to relieve any suspicion that NS-nurses were occupied to an -inordinate degree in unrelieved hard work for the health care of the community. ${ }^{2}$ It would also be stressed in the propaganda material that the descripton of tasks of the NS-nurse should include as much information on the three existing groups of Nazi nurses (NS-Schwesternschaft, Schwestern DRK, Reichsbund der freien Schwester und Pflegerinnen e.v.) as possible. ${ }^{3}$ Most importantly it would be pointed out that the task of the nurse was something which had an 'exalted' side (not an altogether unfamiliar idea, given that the nurse in many societies, though not necessarily highly paid, was and perhaps still is, viewed in such a way by those in her care). ${ }^{4}$ The introductory propaganda material however, would include an emphasis on short items which covered such themes as:

a) Serice for the individual or service for the Volk?

b) The activity of the nurse in war-time;

1. BA, NS 22/747, 'Arbeit der NSV', 'Vorpropaganda und Beeinflussung'.

2. Ibid., 'Aus dem Tagebuch von Schwester Else'.

3. Ibid., 'Die drei Schwesterngruppen'

4. Ibid. 
c) The nurse and her work;

d) Nurse or daughter? (Haustochter).

A follow up to this introductory material would then go on to explain in more detail (after the listener's interest had hopefully been raised) to include an explanation of important factual information such as how one became an NS-nurse, the cost, if any, of the training, and where one could receive information on a career in nursing. Information on what the nurses were expected to learn was included in this later material as well as an expansion of the ideologically motivated theme of 'from nurse to housewife'. ${ }^{2}$ The very carefully organised series of broadcasts shows how anxious the NSV was, and how seriously it regarded attempts, to gain more recruits for the NS-nurses. The broadcasts would be given support by printed articles in the press, and Kreis offices would hold open discussion times on the subject of the NS-nurses. ${ }^{3}$ The sophisticated propaganda material may have been originally designed by the Propaganda Ministry rather than the NSV, though no mention was made of this in the hand-out for NSV staff; however, it seems more than likely that such was the case given the style of the layout of the material which was very similar to some of the WHW propaganda. In the special field of arranging for a community service of nursing staff who would be available for consultation by the public at the local level, the NSV seems to have had if not a monopoly, then a free hand. ${ }^{4}$ But the NS-nurse was not a particularly popular figure,

1. BA, NS 37/1042, 'Werbefeldzug Schwesternschaft', 'l-16 Januar, Vorpropaganda', p.l.

2. Ibid.

3. Ibid., see 'Allgemeine zur Werbewelle', p.2.

4. BA, NSD 30/4a, NS-Volksdienst, December 1943, pp.174-175.. 
especially if she was used to replace confessional nurses, or nuns, in existing nurseries and kindergartens. In the work of community health care the NS-nurses seem to have taken an important, even leading role, though this did not mean an automatic attainment of popularity, as Kershaw has shown. ${ }^{l}$ In Bavaria the replacement of Catholic nurses by those of the NSV during 1941 only served to increase the climate of unrest which had been caused by the general clamp down on the churches at that time. The attempt to put NS-nurses in the Bavarian nurseries in place of nuns was entirely unacceptable to the population at the time and certainly calls in question the general popularity of the Nazi nurses as a whole. ${ }^{2}$ For example, one SD report showed the NS-nurse was regarded to be less well trained than other nurses and that she was regarded as an unwelcome addition to community health care in general, especially in Catholic areas. ${ }^{3}$ However, the attempts to replace confessional nurses with Nazi nurses was part of an emphasis upon a reduction of the influence of the church in favour of the Nazi Weltanschauung, in the area of health and welfare care of children. ${ }^{4}$

In 1937 the scope of the activities of the NS-nurse was significantly increased, and those NS-nurses who had completed their training would find that they would be sent to the border areas of Germany in order that the populations there would be encouraged

1. Kershaw, Popular Opinion, p.333.

2. Ibid.; SD reports showed how unpopular the NS-nurse was (1943). I am grateful to Dr Jill Stephenson for confirming this.

3. Ibid.

4. J.S. Conway, The Nazi Persecution of the Churches 1933-45, London 1968, see Appendix 15, p.383. 
by the provision of a health care service to give a stronger allegiance to the regime. This development would how itself more clearly from this time on. ${ }^{1}$ Two new Reichschulen were opened in Dresden and Dortmund and in special extra monthly courses the NS-nurses were given ideological training in the various aspects of their work. ${ }^{2}$ With the beginning of the war however 'special duties' were created which allowed that NS-nurses would be sent to the newly occupied areas as well as the border areas of Germany. The first extension of the work of the NS-nurses had occurred in Bavaria in $1937 / 38$ where new community health care stations were set up. In the Bayerische Wald area, 75 of these stations were established, in the main, it was said, to combat the scourge of infant deaths in the district or - perhaps more realistically - to prevent, or at least inhibit, the practice of abortion. NS-nurses were also taken into the SS-Lazaretten, the SS Mothers' homes ("Lebensborn" e.V.), the Ordensburgen and into NSV institutional provisions for juveniles. ${ }^{3}$ By 1937, the membership of the NS-nurses stood at 3,751 trained and 1,471 nurses still in training. ${ }^{4}$ In 1938, the NSV took over many of the existing schools of nursing and it was reported that 36 hospitals belonging to the NS-nurses were now in existence. This is to say that by the beginning of the war the NS-nurses' organisational activities had been ranging widely, from local community health care to work in the SS "Lebensborn" Homes. However, the start of the war

1. BA, NS 37ii/1040 'Entwicklung der NS-Schwesternschaft', Pp.1-4.

2. Ibid., p.l.

3. Ibid., p.2.

4. Ibid. 
saw them begin to travel ever more widely through the occupied areas of the Nazi regime, for example, in the Sudetenland (where 60 NS-nurses already lived) 180 were sent to carry on with community care there. In the Protektorat Bohemia-Moravia as many as 600 nurses were made available, while Wartheland received only 30 , but this particular number would increase and they would, in Wartheland, undertake to provide all manner of care for mothers and children there. $^{1}$

In the first year after the 'Campaign in the East', the newly occupied areas could count 300 of the NS-nurses who had been placed within newly created Community Health stations, and approximately 400 nurses had been set to work in hospitals. By 1939, the membership of the NS-nurses was approximately 10,586 with slightly more than half of that number consisting of trainees. ${ }^{2}$ After the fall of France and Belgium and by an order of Hitler, 100 nurses were dispatched into these countries for the 'care of the populations there'. This was entirely in line with the work of the NSV which would also go into France and Belgium, at first, mainly to oversee the flow of refugees and to secure food supplies where that was possible. 3

Other new tasks for the NS-nurses would emerge in 1941 which involved working not only in the Alsace-Lorraine, Eupen, Malmédy and Luxembourg, but in the Netherlands as well. Norway would also receive an influx of the NS-nurses; however, it seems that this

1. Ibid., p.3.

2. Ibid., p.3, see also BA, NSD 26/261, 'Aufkommen und Verwendung', p. 40 .

3. BA, NS 37ii/1040, 'Entwicklung der NS-Schwesternschaft', pp.3-4. 
venture was probably restricted entirely to the use of these nurses by the SS in their own medical facilities. ${ }^{l}$ It seems that the NSV was providing a useful service for the SS in this respect by allowing their own trained staff to be used by the SS medical clinics where necessary. ${ }^{2}$ Other duties included the reception of repatriated ethnic German (Volksdeutsche) and this service was provided for those returning from the eastern areas of Galicia and the Ukraine. In Lithuania, 42 nurses were available to aid the returning Volksdeutsche who had been accommodated in special reception camps. ${ }^{3}$

The growth of the NS-nurses organisation, going as it did from 1,001 in 1934 to 7,679 in 1941 (to which figures should be added the numbers in training for these years that is, 396 in training in 1934 and 4,035 in training in 1941), may have represented something close to an optimum growth in numbers for during the war there existed a very serious shortage of NSV Volkspflegerinnen in practically every Gau, which meant that NSV staff had to be supplemented by newly created Volkspflegehelferinnen who underwent a shortened training course in the NSV training schools so that the duties of the NSV Volkspflegerinnen could be taken over by trained personnel, even if the length of the training courses (four months) could hardly match the normal two-year course of the fully trained NSV Volkspflegerinnen. 4

1. BA, NS 37ii/1040, 'Entwicklung der NS-Schwesternschaft', p.4.

2. Ibid., p.4.

3. Ibid.

4. This shortened course did not ignore ideological training, BA, NS $37 \mathrm{ii} / 1010$, 'Rundschreiben Nr. 91/43', 28th May 1943; $B A$, NSD 30/50 Schule fUr das Leben, p. 23 . 
The NSV's involvement in health care which included a close participation in the important measures for combating TB, was organised through its own TB Hilfswerk section, which was included within the NSV Amt Volksgesundheit. This particular arrangement within Head Office in Berlin was divided into five sections:
a) Heilverschickung;
b) Arztliche Leitung der Erholungsverschickung;
c) Gesundheitshilfe;
d) Gesundheitsfursorge;
e) Verwaltung.

Through the NSV's TB Hilfswerk it was possible for citizens who were acceptable to the NSV on the basis of their own strict guidelines to receive assistance with the costs which might be incurred by patients who had to undertake a spell in a sanatorium or other type of TB hospital or TB clinic. This was seen by the NSV as a means of encouraging effective preventive medicine, which would not only help to heal the sick, but prevent the spread of the disease within the population at large. It would be possible for those in need to obtain financial help from either the Hitler-Freiplatz Spende but more usually the NSV, when insurance or other financial support had run out, or was perhaps proving to be inadequate. However, this financial assistance acted as a safety net only for certain categories of patient who were not regarded as incurable, and only medium to light cases would obtain such help. ${ }^{2}$ At all times the financial help received would, primarily, be an addition to what

1. BA, NS 37ii/1010, 'Amt fUr Volksgesundheit in Hauptamt fUr Volkswohlfahrt', 1936; BA, NS 37ii/1001, Fol. 2, 'Das Wesen', p. 7 .

2. Reher, Social Welfare, p.30. 
could be received from all other sources. As Werner Reher explained,

'The fight against tuberculosis furnishes one of the most important grounds for the activities of the NSV. This is a problem that is of primary importance not only in Germany, but in all civilised countries. The tuberculosis problem is not a new phenomenon. But the fight against it has hitherto not been conducted under a unified command. For this reason a Central Committee to combat tuberculosis was established in 1933'.

It was within the framework of this committee that Reher placed the activities of the NSV. For it was within such an attempt to take on the problem of combating TB within the population at large that the NSV's work was perceived. ${ }^{2}$ It was considered that the NSV's resources could be put to good use by 'filling gaps' where the need arose, and this would serve to consolidate the fight against TB itself. Both the medical and insurance authorities had, Reher explained, been finding the cost of a TB aid programme difficult to support and it had been a long, continuing problem which, from 1933, promised to receive an increased input of resources from the Party, through the NSV rather than from the government itself. Reher was most concerned to stress that there was no question of relieving others of the financial responsibility for such work, but the NSV would be charged with seeing to it that those who were responsible for the financial costs of a cure, the social insurance funds and other sources of financial support for the treatment of TB, were meeting their full responsibilities and obligations in an efficient way, so that to this extent the NSV was keeping a close watch over this activity. ${ }^{3}$ However, when financial support for individuals came

1. Ibid.

2. Ibid.

3. Ibid. 
to an end, according to the terms of an existing social insurance contract, the NSV would step in and take on the responsibility of further supporting those TB cases who came into difficulty, by meeting any further costs. As the complicated application form of the NSV Tuberkulose Hilfswerk showed, detailed questions would be asked about the financial situation of the applicant. Equally detailed answers would have to be given regarding whether the applicant had been insured through either:

1. Landesversicherungsanstalt

2. Sonderanstalt der Invalidenversicherungsanstalt, or indeed any other type of social insurance scheme in which the applicant had become involved. These questions would be asked in order to see whether the aid coming from such schemes available had been fully exhausted. ${ }^{1}$

However, the NSV saw its role within such health care schemes, mainly as a preventive one so that it would also be prepared to offer aid for measures designed to improve the living conditions which tended to encourage the spread of disease. These were seen by the NSV to consist primarily of the prevalence of an insidious and continuing under-nourishment of certain sections of the population, insanitary housing conditions and insufficient clothing and warmth in the winter. ${ }^{2}$ To some degree the WHW would supply a minimum of these needs for those who were unable themselves to purchase sufficient quantities of fuel or of certain important staple items in the diet. It can be argued that the population as a whole was better fed at the start of the war than would have been the case without the input of

1. BA, NS 22/751, 'Richtlinien fUr TB Heilstattenkuren', n.d.

2. Reher, Social Welfare, p.31. 
WHW aid. It might also be that the ability of the Germans to prevent major epidemics during the war was due in some part to the continued donations of foodstuffs and of vitamin supplements which could be obtained from the NSV, so that there existed a majority of people who were not going completely without the more important items in the daily diet. The NSV was most emphatic about the necessity of good dietary habits and promoted this idea whenever the occasion arose, especially to mothers who were strongly urged to think seriously about the nourishment of their children. From this point of view the NSV could be seen to be involving itself closely within the health care measures of the regime, and in a distinctive way, supporting the measures of the Office for the People's Health. A deep interest in preventive health measures underwrote many of the NSV's schemes which, though restricted to certain sections of the German population only, which diminished their value, can be seen to have been forwardlooking and perhaps entirely effective in the sense that they were widely available in many instances. For example one report about the economic situation in the Gau Mecklenburg in 1941 pointed out that due to severe shortages of goods such as children's shoes in the area, one mother had been prompted to write,

'what use to me are Vigantol and Cebion-Zucker (two vitamin supplements) when my child is learning to walk and I cannot find any shoes to put on his feet'.

NSV concern with preventive measures meant that it stressed the importance of supporting the breadwinner of a family who had to go

1. BA, NS 1/285, Fol. 447, Der Gauwirtschaftsberater, Gau Mecklenburg, 'Bericht Uber die Wirtschaftslage in den Monaten Myrz/April 1941'. 
for treatment for TB, if necessary, as soon as possible and without having to fear for his family's well being. He should be allowed, the NSV emphasised, to take up a place in a hospital or clinic sooner rather than later and not to avoid such treatment through anxiety over financial matters. If early treatment was sought, then the NSV promised to undertake to support the family through its worst financial crises and it would set itself to 'become the trustee of the family and make itself responsible for the family's welfare'. ${ }^{1}$ Whether or not these promises were actually fulfilled, it is clear that the NSV only came forward with its aid, as customary, at the last possible moment when all other sources had been explored, and such aid was given only after a complicated bureaucratic procedure had been gone through which may have hindered the donations of sums of money to applicants.

In $1936 / 37$ the WHW donated RM 3,000,000 to the NSV's IB Hilfswerk but this may not have represented the entire costs of the scheme. So far no figures of the costs of the NSV's aid scheme have been found for they were not included in the Aufkommen und Verwendung of the NSV which only outlined the numbers of cases taken up according to year. ${ }^{2}$ However, the NSV's IB Hilfswerk did take up more cases year by year as the figures show, and from a figure of 1,563 cases in 1935, the numbers of those aided who were sent to TB sanatoria were given as follows:

1. Reher, Social Welfare, p.31.

2. Ibid.; BA, NS 26/261, 'Aufkommen und Verwendung', p.37. 


$\begin{array}{ccc}\text { Year } & \text { Cases } & \frac{\text { Numbers of Days }}{\frac{\text { in Care }}{9,549}} \\ 1935 & 1,563 & 98,549,867 \\ 1936 & 6,179 & 487,103 \\ 1937 & 9,649 & 867,103 \\ 1938 & 10,304 & 1,243,720 \\ 1940 & 9,438 & 1,408,123 \\ 1941 & 8,869 & 1,068,925 \\ 1942 & 10,204 & 1,177,023\end{array}$

It is not, however, clear whether the drop in numbers from 1938 to $1940 / 41$ is due to a decrease in applications made or to a restriction of the service which coincided with the extra war-time activities of the NSV. It may have been that it was due to severe pressure upon the existing numbers of beds available, which meant that more individuals were having to wait for a longer period before treatment could be given. The numbers of existing TB homes and clinics in Germany in 1938 amounted to 160 specialist clinics which could offer 22,150 available beds. ${ }^{2}$ To this was added the 15,000 hospital beds which were made available to those cases requiring urgent treatment before a bed could be found in a TB clinic. From the figures given above it seems that the NSV may have been supporting under a third of the existing TB cases according to beds available from about 1940 or thereabouts. ${ }^{3}$ Also in 1938, the NSV made strenuous efforts to discover how effectively the provision of TB care was being organised, and questionnaires were sent out to all TB Homes and clinics in Germany with the request that they make known how long

1. Ibid.

2. BA, NSD 30/11, Informationsdienst, March 1939, p.98.

3. Ibid.; Informationsdienst, November 1938, p.33. 
their waiting lists were. ${ }^{1}$ From the replies to the NSV questionnaire it seems that the average waiting time was 4-6 weeks in a majority of cases, while in a smaller number of clinics the waiting time was reported to be about 8 weeks or slightly longer. ${ }^{2}$ At this time the NSV was in the process of encouraging clinics only to take up those cases which could be described as having a hopeful outcome, and they were reminded that they should seek to make beds available for those cases which required surgical treatment which could itself aid a speedy recovery or, at least, offer the promise of a shorter stay in the clinic. The terminal cases would be disregarded entirely by the NSV it seems and pressure would be put on clinics to do likewise and one way of discovering how efficient clinics were in choosing 'suitable' cases was to keep a close watch upon the numbers of cases awaiting treatment. ${ }^{3}$ The harsh and pitiless selection procedures which the NSV wished to encourage were entirely in line with NSV policy of course, and certainly supported the absence of a charitable impulse in the search for efficient use of existing resources. ${ }^{4}$

There is no doubt that there existed effective TB health care in Germany, for the German figure of 6 deaths per 10,000 of the population in 1937 could be contrasted with the Austrian figure of 10.1 deaths per 10,000 in the same year. As soon as Austria was included within the Reich a TB action was set up and the NSV began its work there; 20 new clinics were supplied through the office for People's Health and the Austrian arrangements for TB care were

1. Ibid.

2. Ibid.

3. Ibid.

4. Ibid. 
brought into line with the German ones as soon as possible. ${ }^{l}$ This swift appraisal of the health arrangements for combating the disease of TB was later introduced in the occupied areas too, for in 1940 Conti made a visit to Wartheland and decided that a 'TB action' had to be put into operation right away under the supervision of German doctors, though Polish TB cases would be treated by Polish doctors only. It was reported at the time that the previous Polish arrangements had been so 'lax' that a virtual epidemic of the disease existed in this part of the former Poland (Litzmanstadt). Whether or not such was the case, the input of a German TB action would separate the lighter cases from the more hopeless ones and no doubt introduce an 'efficient' treatment of the disease. ${ }^{2}$ It is not clear what the immediate fate of the rejected cases in Wartheland was.

In Austria in 1938 the NSV would support the battle against TB with sum of RM 420,000 but the undoubted success which were achieved in Germany were outlined in the figures of the NSV which gave the numbers of deaths from the disease from 1881/85 to 1934 (Prussia), and within Germany itself up to 1936. These were given as follows:

1. Ibid., Informationsdienst, March 1939, p.98.

2. HA, 13/260 'Artikeldienst' ii, ld/22407, 'Energische Gesundheitsfuhrung im Warthegau', 20th July 1940. 
Percentage of deaths per 10,000 of the population from TB

Males

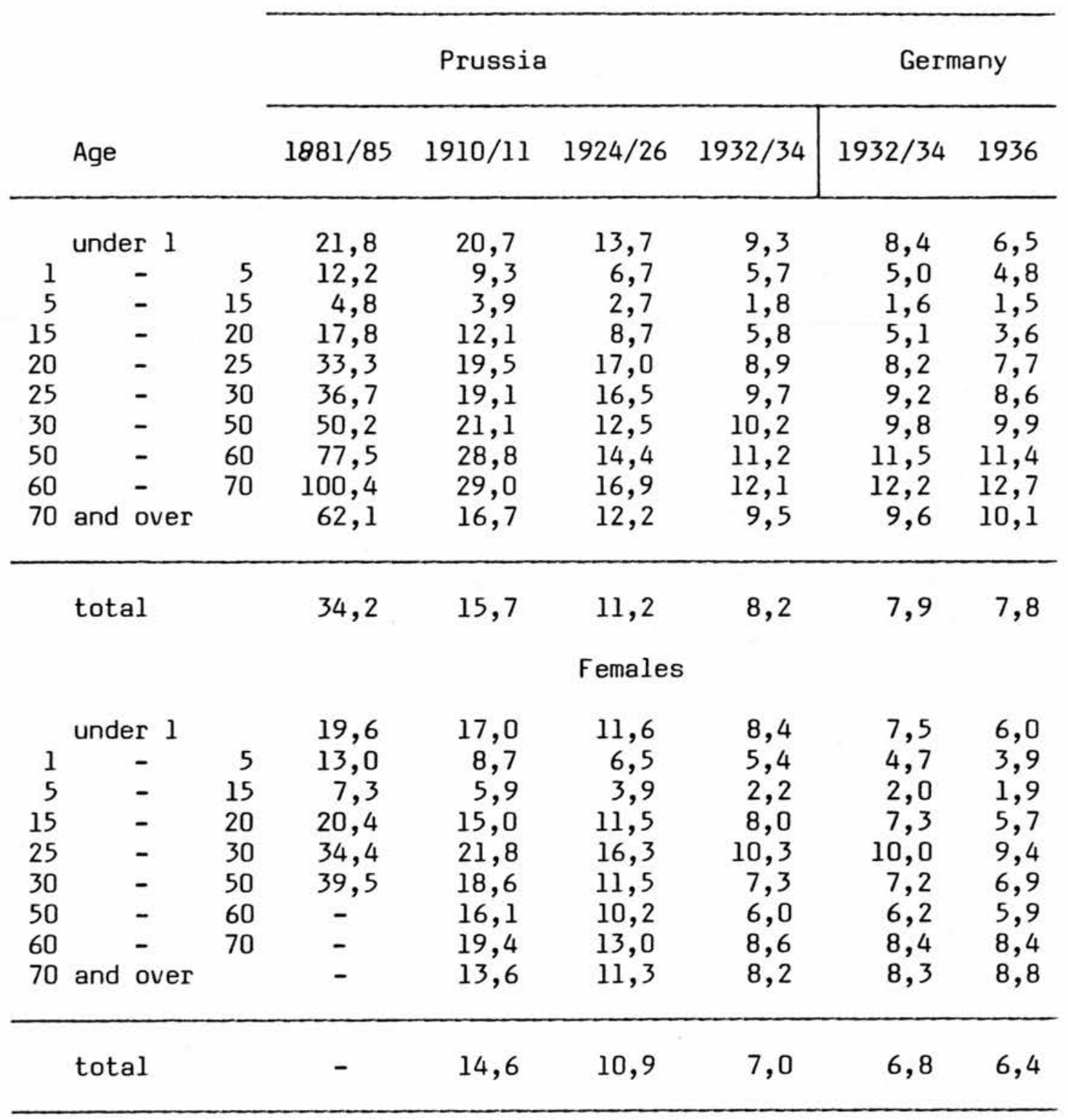

(1)

The improvement in the numbers of cases was seen in the numbers of deaths in the higher age groups of women rather than men, in the

1. BA, NSD 30/11, Informationsdienst, November 1938, p.33. 
years 1932-36. However, the figures for female deaths showed a tendency to fall (1936) from the age of 30, while for men, the numbers of deaths rose after the age of $25-30$, in 1936. The numbers of deaths in the age group 50-60 of women were much lower than for men of the same age in 1936; but for younger women aged between 15 and 30, the prospect was less hopeful. This no doubt represented the period of the most fertile years, and the interesting drop in such figures in later age groups showed a marked contrast with the higher figures for male deaths between the ages of 30 and 60 years. ${ }^{1}$ The figures for Prussia as a whole show how the fall in numbers of deaths from TB had occurred at a steady rate and were being continued in the years 1932-34. The presentation of the improvements in the figures of deaths after 1933 from the disease were, however, given without claiming prime responsibility for the NSV or the Party in this work but rather as a study of how the scourge of TB had been successfully reduced during the fifty years from the 1880's to 1930 's. ${ }^{2}$ It seems possible to say that the NSV made less of an issue of the propaganda effects of such work though they made reference to the IB Hilfswerk whenever the occasion arose. But the section itself seems to have operated from the point of view of a genuine, though harsh, attempt to provide health care rather than from the point of view of gaining 'support' by constant reference to the measure. However, this must remain a tentative conclusion only. But it seems that the main function of the IB Hilfswerk was to ensure a 'rationalisation' of treatment procedures which depended upon a selection from among the

1. Ibid.

2. Ibid. 
cases coming forward for treatment - The fact that the NSV was in a position to offer help to those in need meant that the early intervention policy may have served to bring cases forward for treatment sooner, given the necessity of proving one's 'suitability' for financial help. ${ }^{l}$ Even if this effect could hardly be described as being inspired by charitable goals, then the application of a first come, the more likely to be served principle, may have operated to improve the chances of those few who had come forward for treatment through seeking aid from the NSV for their families for the duration of the spell in a TB clinic or hospital. ${ }^{2}$

1. Reher, Social Welfare, pp.30-31.

2. Ibid. 


\section{CHAPTER SEVEN}

WAR-TIME ACTIVITIES OF THE NSV: WELFARE IN THE OCCUPIED AREAS AND THE ALTREICH DURING THE WAR

Fanfares of Victory ${ }^{1}$

A clear distinction should be made between the activities of the NSV in the period between 1940 and 1943, and those of the period between 1943 until the end of the war. In the first phase, the activities of the NSV, as they related to specific war-time duties, showed a marked degree of optimism and enthusiasm for the new tasks, both in hand and in sight. Expansion was the order of the day, and the extension of the organistion within every one of its social welfare measures in the Altreich as well as in occupied areas, promised Hilgenfeldt, Althaus and Reher that due to the war, the developments of the recent past were now, being consolidated. This was seen nowhere more clearly than in the growth of NSV participation in the provision of kindergartens, in the activities of the 'Mother and Child' section and in the new supportive role of the Kriegswinterhilfswerk in the work of the DRK. ${ }^{2}$ In Austria, and later in the Netherlands, in France, Belgium and in the occupied eastern areas, the NSV expanded greatly, even massively, and promised to become a real force to be reckoned with after a victorious war. One of the most important duties of the organisation in the period of the successful part of the war, when Blitzkrieg had delivered vast areas of the continent of Europe into German hands, was the swift and unexpected incursion of the NSV into France and Belgium on the heels

1. Bramsted, Goebbels, p. 295 .

2. See this Chapter. 
of the German army in the summer of 1940. It would also later move into the occupied territories in the east. ${ }^{1}$ The enthusiasm with which the NSV went into France, especially, revealed the effects of the welcome taste of victorious conquest which the NSV officials who visited these areas themselves experienced. Senior officials of the NSV would travel through the newly acquired regions of Western Europe, and reports from Paris and Brussels show the impact of the German victories in the west on NSV staff, one of whom, Werner Reher, could not contain his delight in finding himself driving through the French countryside into an area where he could freely organise NSV special welfare measures, at this time only for some refugees and other special categories, but later more extensively in Alsace-Lorraine. ${ }^{2}$

In the summer of 1940 , less than a month after the signing of the armistice between France and Germany on 22nd June, a visit by Hilgenfeldt, Reher and senior NSV staff was made to inspect the Sondereinsatz (special assignment) of the NSV. Reher seems to have made a visit to Paris, parts of Belgium and northern France, and Hilgenfeldt travelled to Compiègne in France to inspect an NSV refugee camp which had been hurriedly set up there. ${ }^{3}$ Perhaps this NSV welfare action might be described as the reverse side of the introduction of the Einsatzgruppen of the SS who also entered the

1. HA, 13/260, 'Artikeldienst' 11/1d/15407, 'Der Parteieinsatz im besetzten Gebiet ( 1 ): Mit der NSV. in Belgien und Frankreich,' 6th July 1940; see also BA, NS 26/260, report to Berlin on NSV 'Ukraine'.

2. HA, 13/260, 'Artikeldienst' 11/1d/15407; 16407, July 1940; see also Grill, The Nazi Movement, pp.612-621.

3. Ibid., 'Artikeldienst' 11/1d/15407, 'Mit der NSV in Belgien und Frankreich (2): "Venez à la NSV.!"' 10th July 1940. 
conquered territories in the east after the victorious German armies.' Required to 'clean up' the areas in question through the removal of obstacles to a German occupation, the NSV in the west was expected to give aid and attempt to organise existing food supplies and to oversee the movement of refugees. Refugees and others who belonged to the perceived 'valuable' nations such as the French and Belgians (who were regarded to be less 'valuable' racially than the Dutch or the Norwegians), would receive an initial amount of German aid and supervision to relieve their immediate problems. As Reher explained, they would experience the magnanimity of the Germans who would not impose upon the population the harsh oppression of a conquering nation. ${ }^{2}$

At the beginning of June 1940 the NSV went into these countries after a special order had come from Hitler at that time. Hilgenfeldt had been flown to the FUhrer headquarters on 3rd June 1940, and given instructions that the NSV would be expected to carry out special duties in the newly conquered areas in the west. On the 'same evening', five Gauamtsleiter of the NSV from western Germany were charged with this task. Every Gauamtsleiter had to find 10 Kreisamtsleiter or suitable Ortamtsleiter, and twenty nurses of the NS-Schwesternschaft, so that the NSV could begin what amounted to an emergency rescue operation following the army's victory. Reher was pleased to report that the operation was carried out tirelessly and

1. Ibid., 'Artikeldienst' 11,1d/16407, 'Mit der NSV in Belgien und Frankreich (Schluss): Beim Einsatzstab Paris', 14th July 1940; Wright, The Ordeal of Total War, pp.123-139.

2. Ibid., 'Artikeldienst' 11/1d/15407, 'Der Parteieinsatz im besetzten Gebiet (1)', 6th July 1940. 
enthusiastically. ${ }^{1}$ NSV activity in the summer of 1940 in the area of Alsace-Lorraine, and in northern France, was essentially a preparatory exercise designed to seize hold of the existing resources of the areas in question. In France especially, refugee camps would be required, and special accommodation made available, for certain categories of individual. For example, in Brussels a special home for Reichsdeutsche and for nationals of friendly countries was set up, and this home was able to accommodate 100 to 130 refugees and others. The consulates of the friendly nations were contacted and they were asked to report to the NSV on the situation regarding their own nationals, who would be cared for by the NSV in Belgium and France. ${ }^{2}$

Evidently 'no-one' was turned away; one example of such a friendly national was a Hungarian Bergarbeiter who was given help for his wife and two children in Bussels at this time. In Paris, consular officials expressed 'deep gratitude' for the help of the NSV. When those consulates were later visited by Reher (and possibly Hilgenfeldt) they 'endlessly' expressed wonder over the efficient organisation of the work of the NSV. ${ }^{3}$ In 1940 one hundred lorries with various types of food and with assorted clothing, were driven into France following after the victorious army. These lorries when empty were used to return refugees to their own homes thus swiftly relieving whole areas of unwanted, slowly moving columns of people. One of the main functions of the Sondereinsatz of the NSV was to achieve this goal. The NSV supply centre in Brussels

1. Ibid.

2. Ibid.

3. Ibid. 
attempted to pull together all the strands of the activities regarding the control of the refugees from the disrupted (and destroyed) areas of France and also tried to control the flow of the refugees coming from the south. ${ }^{l}$ Reher was most anxious to distinguish between the situation of the French and Belgian refugees, and that of the refugees in Poland. He pointed out that unlike the Polish people, the French and the Belgians came from 'civilised' countries whose inhabitants were thrifty, industrious and essentially independent. The 'Rentner Ideale', added Reher, is 'nowhere as strong as it is here in France'.

With Reher and other leading NSV officials, Hilgenfeldt visited the temporary NSV camp at Compiegne in which French military doctors, would find themselves working for the NSV which had removed them from the prisoner-of-war camps expressly for this purpose, and they had been set to caring for the refugees. ${ }^{2}$ Rapidly, and perhaps ruthlessly, the NSV proceeded to organise and 'rationalise' the use of resources whether they consisted of supplies or of trained French personnel.

Not only doctors but other captured military personnel were transferred to work in the NSV refugee camp in Compiègne for the purpose of caring for the refugees whose numbers Reher described as growing 'all the time'. 3 In the 'light of a candle', as Reher reported, Hilgenfeldt and his staff were given information about the whole NSV Einsatz in France and Belgium. Very soon, NS-Nurses and Frauenhilfsdienstmadel would be sent into France, some of whom

1. Ibid.

2. Ibid., 'Artikeldienst' 11,1d/15407, 'Mit der NSV in Belgien und Frankreich' (2): 10th July 1940.

3. Ibid. 
went to Compiègne. According to Reher, as many as 10,000 people were reported to have been given some form of help and assistance during one day in 1940 in France. ${ }^{1}$ The NSV refugee camp in Compiègne had been set up in a former school and women and children were given sleeping quarters in the reception rooms. It was here that Reher discovered a blackboard on which was written, 'Maman et enfants, venez à la NSV., acceptez ses bons soins sous le patronage du Fuhrer Adolf Hitler'. 2 This statement delighted Reher greatly, for he believed it to have been written by a French woman refugee, and it was taken, apparently, as a good omen. The NSV team travelled to Paris some days later, and a brief sight-seeing tour was made. Reher and others took a stroll up the Champs Elysées to the Arc de Triomphe in the vicinity of which was located the NSV Einsatzstab Paris. The so-called 'gigantic' tasks to be undertaken were described, apart from the regulation of the flow of refugees, as consisting of taking over control of the Parisian stores and warehouses to prevent plundering. The French Red Cross at this time would find that they would come under the control of the NSV and that they would be directed to work with refugees under the direct guidance of NS-nurses. ${ }^{3}$

As in Brussels, arrangements were made in northern and western France with consulates of the friendly nations for the special care of their own nationals. From Paris the NSV team went on to Le Havre where Reher ended his report, and he recorded that in the seven days'

\footnotetext{
1. Ibid.; see also 'Artikeldienst', III, ld/14408, 'So hilft die Partei den Elsassern', 13th August 1940.

2. Ibid., 'Artikeldienst' 11, Id/15407, 'Mit der NSV. in Belgien und Frankreich (2)', 10th July 1940.

3. Ibid.
} 
journey through France and Belgium it could be seen that the National Socialism would not take the road of other traditional war-time practices and the NSV would be prepared to help civilians in the war endangered areas. The 'Wehe den besiegten' was not taken up by National Socialists who had shown 'real dignity' and 'honour' in the victory over France and Belgium. ${ }^{l}$ But not, it must be added, either in Poland or in Russia.

\section{Alsace in August 1940}

Enthusiasm was shown also in the welfare measures which began the work of the NSV in the region of Alsace-Lorraine. This area, the NSV said, had been 'shamelessly plundered' by the French troops, houses had been burned and 'senseless destruction' lay everywhere. ${ }^{2}$ The area was said to be derelict and lacking the most basic necessities such as shelter and food. Soon in Alsace the 'new letters of the NSV' appeared on posters and in public transports, giving information regarding emergency feeding centres and other facilities. In Colmar where the NSV would later set up its offices, an emergency kitchen was organised in a former German Volkskllche which had long since been closed by the French. ${ }^{3}$ In Mulhouse, Strasbourg, and in other towns, the feeding problems were described to have been 'solved'. It was also reported that many were genuinely grateful for the help of the welfare organisation at this time and according to a British report of these actions, (viewed by this primarily as a German propaganda exercise) they seemed to have

1. Ibid., 'Artikeldienst' 11, Id/16407, 'Mit der NSV in Belgien und Frankreich (Schluss)', 14th July 1940.

2. Ibid., 'Artikeldiest' $111,1 d / 14408$, 'So hilft die Partei den Elsăssern', 13th August 1940.

3. Ibid. 
succeeded in providing emergency facilities for many who were without shelter or food at this time. The rapid NSV entry into Alsace. Lorraine was of course mainly a preparation there for the restoration of German rule in that area and this would be achieved and carried out with success, for the Gau Baden would take over all NSV activity in Alsace. ${ }^{l}$ NSV personnel also undertook to supply special aid in northern France with the main task of organising and controlling the distribution of food. In Arras, Lille, Bèthune and Amiens the populations there would find that the NSV had taken control of special emergency feeding arrangements, but it had also taken possession of supplies left behind by the departing British army so that some families found that they were being allowed captured tins of British condensed milk and some other items for the children. ${ }^{2}$ But all this activity had been carried out less for the benefit of the population in such areas than in the interest of the occupying troops, as well as being a preparatory measure which would support an initial NSV presence in the newly conquered west. The propaganda value of such activities according to British reports may have been 'considerable'. However, whether or not this claim was valid is less important than a consideration of its real function. 3

All this activity must be seen as part of the initial creation of the Nazi New Order, for German policy at this time envisaged a 'great constructive enterprise' taking place within the occupied areas. The necessary prelude to reconstruction had been conquest,

1. Grill, The Nazi Movement, pp.612-621.

2. HA,13/260/Artikeldienst 11,ld/16407, 'Die NSV hilft in Nordfrankreich', 1940

3. Basic and Zonal Handbook, Chapter VII, pp.169-170. 
but in France and in Belgium, where the populations were regarded as 'racially valuable', it would be the NSV and its Sondereinsatz which would enter these areas, not the Einsatzgruppen of the SS.

A year after the NSV Sondereinsatz in Alsace-Lorraine and in Luxembourg, other Nazi organisations would set up their operations, for example, the NSF/DFW would carry out its measures and activities for mothers in the area and indeed the whole paraphernalia of German social welfare activity would be introduced. ${ }^{2}$ In Alsace where the NSV would become firmly established, the organisation would spend the first few months supervising the returning Alsatians and setting up its own organisation. Indeed, the NSV offices in Colmar would continue to function until the end of 1944, at which time the NSV there reported on a hopelessly deteriorating situation. However, until that time the Gau Baden would act in a controlling role over the Alsatian operation, building an NSV organisation of some considerable size which was dedicated to supporting the German occupation there. ${ }^{3}$

The creation of the new Nazi Order in the east was also supported by the strong presence of the NSV in Hungary, which according to reports from the Hungarian NSV, could be seen to be popular with the Volksdeutsche there. By 1944, the Hungarian organisation could count 155 head office staff, 42 GebietsKreiswalter, 24 Kreisabteilungsleiterinnen and as many as 20,000 honorary helpers. According to Dr. Schlitt, the Landeswalter of the

1. HA, 13/260, 'Artikeldienst' 11,Id/15407; 16407; July 1940.

2. Stephenson, The Nazi Organisation of Women, pp.178-207.

3. Grill, The Nazi Movement, pp.608-621. 
NSV in Hungary, the success of the Winter Aid there was assured by its popularity which would be seen in the huge increases of the amounts which had been donated in 1943/44. These were described as being 100\% over the previous year of $1942 / 43$ and his report included hopeful plans for the Winter-Aid Drive in the coming year 1944/45. ${ }^{1}$

If such a glowing report may be believed, it seems that the NSV's most successful venture in Hungary was the 'Mother and Child' operation which had shown itself to be popular. As Dr. Schlitt pointed out, apart from its health-care value, the 'Mother and Child' scheme was of great significance, both from an ideological and from a political point of view. ${ }^{2}$ To this extent the NSV in Hungary regarded the MuK as being of 'great value' for the fostering of a strong sense of 'Germandom' within the Volksdeutsche population. From the numbers of the facilities which were being put to use, and in the absence of reports to the contrary, it is clear an effective NSV operation had been established in Hungary. Apart from those facilities which had been set up for the use of the wives of the SS in the district of Neustatz, it was reported that approximately 20,000 Volksdeutsche women and children had been making use of the Hungarian 'Mother and Child' facilities. This included the provision of kindergartens and other special harvest kindergartens. Some 700 mothers during the period of a year had made use of the holiday arrangements provided, and in the whole two and a half year existence of the 'Mother and Child' operation 2,000 women had been allowed a

1. BA, NS26/260, 'Rechenschaftsbericht Uber das IV. Kreigs winterhilfswerk des Deutschen Volksgruppe in Ungarn 1943/44', 25th November 1944.

2. Ibid. 
four week break through the Hungarian Muk. ${ }^{1} \mathrm{Dr}$. Schlitt seems to have genuinely believed in the ability of his own Muk operation to offer the means by which views of women could be 'strengthened', and that their attitudes could be shaped by access to such facilities, and he saw the whole measure from the point of view of gaining the loyal participation of those who were involved in the new adventure of Germanising the eastern parts of Europe. ${ }^{2}$

Whether such a report was greeted with relief, or disbelief, in Berlin, NSV activities would continue to be carried out in the occupied areas nowhere more determinedly perhaps than in the Ukraine where the NSV there would create an organisation in what were admitted to be the most difficult of circumstances. Though a far easier task would face the NSV in Memel where, it seems, much of the work had already been carried out by the Volksdeutsche groups there, indeed it was left to new NSV arrangements mainly to support and to consolidate the work which had already been going on for some time. ${ }^{3}$

One of the first tasks of the new Memel NSV was swiftly to assume command over the existing Memel Winter Aid scheme. This had been very successfully organised by the Volksdeutsche, but it would now pass to the NSV officials furtherto organise and expand the Winter Aid measures there. Based exactly on its model in the Altreich, the Memel Winterhilfe emphasised the principle of 'self-help' and it had supported 3,000 Volksdeutsche in the first

1. Ibid.

2. Ibid.; see also Grill, The Nazi Movement, pp.612-621.

3. HA, 13/260, 'Ǎtikeldienst' 11, Id/30404,'25 NSV.Lastwagen eroberten das Memelland: Ein Jahr erfolgreiche NSV.- Arbeit im befreiten Memelland', n.d. 
year of operation as well as giving holidays to 300 children. ${ }^{1}$ From the membership figures of the Memel NSV it seems that a majority of the Volksdeutsche, 8,600 in all, as the reports claim, were willing to join the organisation. But these and other reports from the occupied areas, including Hungary, were written by officials who were not only influenced by the desire to prove their successes to Hilgenfeldt in Berlin; in addition, they seemed genuinely to believe that a sense of Germandom could be fostered (and strengthened) by the measures of the welfare organisation. ${ }^{2}$ Not only could such measures be used as a method of supporting the process of Germanisation, but they could also be used as a 'signal', back to the leadership, of 'support' for the expansionist goals of the regime. Officials in Memel were pleased to use the figures of the amounts collected for the Winter Aid drives as 'proof' of support, both for themselves and for Nazism as a whole. This is to say that in Memel and in Hungary, the practices of the NSV in the Altreich, which had for long used the sums collected in Winter Aid drives as a barometer of opinion, were also introduced into these countries and in the most emphatic manner. Officials in Memel were happy to report on the collections as having shown the requisite 'spirit of sacrifice' by pointing to the higher sums collected in Memel in comparison with its neighbour in East Prussia. ${ }^{3}$ This only shows however that the NSV had exported its highly competitive practices into the occupied areas as well. Indeed, the belief that a 'sense of sacrifice' had been shown

1. Ibid.

2. BA, NS26/260, 'Rechenschaftsbericht/KWHW/Ungarn 1943/44' Ibid., report to Berlin on NSV 'Ukraine'.

3. HA, 13/260, 'Artikeldienst' Id/30404, 'Ein Jahr erfolgreiche NSV Arbeit im befreiten Memelland', n.d. 
in Memel, and in Hungary through the hard work and effort of officials who had achieved high levels in the collections, only showed how anxious those officials were to fulfil directives coming from Berlin. It did little to reveal the true nature of support or the opinion of the population. ${ }^{1}$ Even though the Volksdeutsche in Memel had shown themselves willing to undertake a Winter Aid drive in advance of the new NSV presence, is unclear how far the process of Germanization could be aided by this means. But the illusion would remain, as it seems to have done also in Alsace where officials there would come to believe in the possibilty of fostering, through the provision of social welfare, a sense of 'acceptance' of German occupation, and the new German Order. ${ }^{2}$

However, the difficult task of the NSV in the Ukraine was reported more honestly perhaps and without making use of the signs and signals of 'proof' of the support of the Volksdeutsche there. ${ }^{3}$ In the Ukraine the NSV had the difficult task of working within a large geographical area, part of which remained in the battle zone and under army control. ${ }^{4}$ In 1943 the existing ethnic Germans, numbering approximately 200,000, would be given welfare help by the NSV. For these ethnic Germans in the Ukraine, (Wright gives a figure of 300,000$)$, a variety of special privileges would be provided, one of which was the provision of welfare from the NSV. ${ }^{5}$ However, NSV activities in the Ukraine would come to a halt in 1943 with the

1. Ibid.

2. Grill, The Nazi Movement, p.614.

3. BA, NS26/260, report to Berlin on NSV operation in the 'Ukraine'.

4. Wright, The Ordeal of Total War, p.110.

5. Ibid., p.115. 
'altered' military situation ${ }^{l}$ namely, the German retreat. Until that time NSV activity in the six Generalkommisariate, Wohlhynien-Podolien, Shitomir, Kiev, Dnjepropetrowsk, Nikolajew and Melitopol had consisted of slowly building up the necessary facilities for social welfare for families. In Wohlhynien - Podolien, where the largest part of the German population had return to the Reich in $1939 / 40$, the remaining Volksdeutsche would find that the NSV was providing 'welfare facility which was designed primarily from the point of view of fostering a sense of 'Germandom' in the children who came into the care of the welfare organisation. For this would be top priority with regard to the support of the population and it would exist as the first duty of 'Menschenfuhrung' in this particular area. ${ }^{2}$ By the summer of 1942, kindergarten work had begun and by September 1943 eight kindergartens had been set up. Familienhilfe was slowly being established, and a children's home had been put into operation. A maternity home for mothers and infants was also made available in Kremianez but it had to be closed again in the spring of 1943 due to the activities of partisans in the area. Alternative facilities however were set up in Luzk. In Generalkommissariat Shitomir which had a population of 48,00 Volksdeutsche, the first task had been to provide a home for orphans and homeless Volksdeutsche children. Nurses of the DRK, members of the NSF and Frauenhilfsdienstmadel all provided medical and other aid. $^{3}$ In Hegewald in the Shitomir district exited 28 villages with 8,000 inhabitants, and the chosen "reindeutsche, Kinderreiche

1. BA,NS26/260, report to Berlin on NSV 'Ukraine'.

2. Ibid.

3. Ibid. 
wertvollen' settlers there were allowed a rapid introduction of NSV Familienhilfe. For this purpose 38 Kindergartens and MuK clinics were established. By September 1943, six Gemeindepflegestationen were added. ${ }^{1}$

In the city of Kiev there were 12,000 Volksdeutsche and the first Mother's holiday homes for their use were opened in the summer of 1943. In many areas of the Ukraine however the NSV warned of the difficult conditions under which the NSV officials would have to work at first, for they would find themselves in a working environment which was described as being of the most primitive kind. Before the whole NSV adventure in the Ukraine came to its end in the autumn of 1943, when the Volksdeutsche were evacuated out of the area and into the neighbouring former Polish provinces, the NSV in the Ukraine had begun to establish its organisation and responded to existing conditions as best they could. But the NSV/Ukraine was established primarily to offer a welfare service which supported the building of a family-based, family-orientated set of measures for the Volksdeutsche population. ${ }^{2}$ This was meant to give aid for those 'frontier settlers' who were to people this land. The support and the ideological training of the Volksdeutsche populations would be a task which the NSV would take on enthusiastically, but how enthusiastically it was received by the ethnic Germans themselves, the NSV in the Ukraine failed to reveal. But the NSV's main concern was a practical, rather than an ideological one at first, with the setting up of facilities in a large area where the existing problems, apart from the activities of partisans in some parts of the Ukraine, ${ }^{3}$

1. Ibid.

2. Ibid.

3. Ibid. 
promised to make such a task a long and a protracted one. But this task would hardly be completed, or even substantially begun, before the developments of the war and the Russian advances would destroy any hopes of colonisation of the Ukraine. This was in an area where, only a short time before, the German presence had looked to be a long-term one. The empire in the east which the NSV would help to create and support would melt away even before the work of welfare for the new settlers and the Volksdeutsche could really begin. ${ }^{1}$

\section{Winterhilfswerk in war-time}

It has been shown that the work of the Winterhilfswerk of the NSV was intended to support several goals whose importance and significance for the regime were to be guaranteed by propaganda measures put forward by the NSV. These goals, which both Hitler and Goebbels themselves recognised as being of prime importance, were given total support through this NSV measure. ${ }^{2}$ During the war, the WHW would continue to operate fully, taking on extra tasks such as the organising of the collections for the German Red Cross. ${ }^{3}$ But there would emerge a different emphasis in the war, one which was conceived as a response to the changed situation in which the mass of the population would now find themselves. The NSV saw its changed, and changing, role to be the urgent task of supporting the home front, relating its measures to this idea and providing welfare for the civilian population whose support for the regime would need to be strengthened and maintained in time of war. The reluctance of the

1. Ibid.

2. $B A, R 36 / 1007$, see detailed instructions on WHW in Mitteilungen der Stadtischen Wohlfahrtsverwaltung Bielefeld, Bielefeld 5th October 1935; Wohlfahrts-Korrespondenz Sozialpolitisher Zeitungsdienst, 'Das Winterhilfswerk 1935/36', 22nd August 1935.

3. BA, NS37ii/1055, 'Propagandaplan des Kriegshilfswerkes fur das Deutsche Rote Kreuz', 18th April 1940. 
leadership to place too many strains upon that popular support would lead to the provision of extra welfare measures. ${ }^{l}$ But the marked reluctance of Hitler to over-strain popular support for the regime would also lead to anomalies arising in domestic policies which in terms perhaps of their unexpectedness is testimony to the seriousness with which the regime viewed the need to preserve this support. ${ }^{2}$ The contemplation of the fall of the Second Reich, caused, Hitler believed, by the 'stab in the back', led to a domestic policy in the Second World War which was dominated by the wish to avoid a similar occurrence. ${ }^{3}$ His fears of civilian discontent directly influenced a domestic policy whose priorities were to avoid discontent at home and to support the home front at all costs. This allowed that the funding of extra social welfare provisions, would continue to be run by the Party agency through semi-official means ${ }^{4}$ and by voluntary donations from the public. This was made clear in the instructions of the first winter war-time WHW; of the eight particular areas to be supported by the WHW in the war, some were familiar, but new areas were to be added. The list outlined by Hilgenfeldt included:

1. the collections for the German Red Cross

2. the collections for the Deutsches Frauenwerk

3. TB Hilfswerk and Heilverschickung

4. Subsidies for the Fuhrer's anti-rickets scheme

1. BA, R18/3781, Hilgenfeldt to Conti, on the extension of the Haushalthilfe scheme, letter of 15 th November 1939.

2. Stephenson, 'War and Society in WUrttemberg', pp.89-91; Winkler, Fraunarbeit, pp.176-186, for a description of lenient conscription policies regarding female labour.

3. Ibid.

4. This refers to the 'donations' from wages and salaries and subscriptions from firms, see BA, R2, 4867, see 'Guidelines', on amounts required to be donated to WHW in 1940/4l. 
5. Help for the war-time duties of the MuK and the NS-Schwesternschaft

6. Aid for the erection and the support of war-time kindergartens

7. Aid for the work in the eastern areas. 1

These various areas of social welfare and health care policies would be given financial support from the WHW until the end of the war. ${ }^{2}$

During the war it was openly admitted that the money collected from the public would now support the newly included - not specifically winter-time - welfare schemes of the NSV. It was now freely admitted that support for the 'Mother and Child' scheme was being funded, in large part, by the KWHW. This seems to have been an admission which could easily be justified in time of war, and there was no need to under-emphasise such funding as there had seemed to be in the peace-time years. At that time the NSV seems to have been very anxious not to complicate the message of 'no-one should go hungry or cold', which was itself the continuing Leitmotiv of all pre-1939 WHW campaigns. ${ }^{3}$ For this reason, the Monatsparole for September 1942 was, '29,000 Hilfstellen (advice centres) of the "Mother and Child" eases the burden of the working mother - for this give your pledge in the Krieqswinterhilfswerk'. ${ }^{4}$ As before, the KWHW would allow some collections to be made for National Socialist organisations such as the NS-Reichsbundes fUr LeibesUbungen

1. BA, R2/4867, Hilgenfeldt to Reichsfinanzministerium, letter of 19th March 1940.

2. Ibid.; BA, R36/963, 'Verfügung $11 / 44$ ', Fuhrerhauptquartier, 22nd August 1944.

3. See Chapter Three.

4. BA,NS 37ii/1016, 'Rundschreiben Nr 3/42', 4th September 1942. 
(Reichsbund for Gymnastics NSRL), and they would find that the KWHW, at least at the beginning of the war, would provide instructions on the activities to be undertaken and provide all the written material which would be used in the press, and design suitable programmes for putting out on radio. ${ }^{1}$ In other words the KWHW would continue to provide an efficient package of advertising material for the Nazi organisations which were still being allowed a set of collections on a specific day during the drive. Other provisions of the WHW would continue as before for the recreation of the population, and free entrance to film theatres would still be available for KWHW recipients. ${ }^{2}$ But more war-time oriented appeals and drives would also take place. The German people would be asked to aid the expansionist aims of the regime by contributing to the specific measures of the newly 'freed' eastern areas, and to contribute aid for the returning Volksdeutsche who required to be given material and other help. ${ }^{3}$ Goebbels himself seems to have taken charge of the appeal for the returning Volksdeutsche from Poland in $1940 .^{4}$ This particular measure was put into operation after the fall of Poland and was intended to gather together articles of clothing for the use of those ethnic Germans now returning to their homeland. ${ }^{5}$ The intention was that every Gaupropagandaleiter of the NSDAP would put out a call for a collection throughout his Gau of warm clothing and anything that could be 'spared' to help the returning Volksdeutsche.

1. BA, NS 37ii/1016, 'Rundschreiben $\mathrm{Nr}$. 3/42', instructions for collections on 19/20th September (NSRL) 1942, 4th September 1942.

2. Ibid.

3. Ibid.

4. Ibid. 
Goebbels ordered that this action be regarded as an urgent one to be taken up as soon as possible, and advertised in the press under strict guidelines which would have to be followed exactly. The appeal would be outlined to emphasise the 20 year 'struggle' of the returning Volksdeutsche who had spent all these years in an unsuccessful 'struggle' to establish themselves in the former Poland and who now had to return, given that the 'war-mongering' of the British had made impossible a continued stay in that land. This had led to the increase of Polish 'hatred' of the Germans so that a continued existence in Poland was now 'impossible'. ${ }^{1}$ How far from the truth such a statement was shown by the reality of the situation which was not revealed in the propaganda. But it was obvious that emotional appeals by the WHW, now KWHW, would continue as before to lend a hand in the instruction of the German people in issues which the Leadership wished to make 'clear' to the people, however distorted the interpretation of events, or of reality itself.

By 1941, Hilgenfeldt was secure enough in his own assessment of the continuing successes of the KWHW to write to Ley to propose that the NSDAP leadership consider lengthening the period of the Winter Aid Drive. His reasons for doing this seem to have been based on the need to raise more money, but he seems to have considered carefully whether or not it would be an unpopular move. From this point of view it seems that Hilgenfeldt was confident enough of the popularity of the drives to put forward a serious suggestion that the public could be asked to put up with an extended KWHW. ${ }^{2}$ Hilgenfeldt was perhaps genuinely worried at this time that the new and increased

\section{Ibid.}

2. BA, NS22/750, Hilgenfeldt to Ley, 'Einnahmen und Leistungen des Winterhilfswerk und der NSV', letter of 8th April 1941. 
level of claims on the KWHW funds could not be met so that it would be necessary to extend the drive by at least one month. Included with the letter to Ley was a selection of the WHW and KWHW statistical material whose use Ley was asked to restrict to those of his closest colleagues according to the Order of Hess of the 25 th October 1939. One at least of the accompanying documents has been consulted here though it seems that many more must have originally existed which perhaps showed details of NSV income levels as well. ${ }^{1}$ However, the Rechenschaftsberichten which are available give detailed information on the amounts of money collected, the amounts raised from the individual Gaus and a detailed account of the items given out according to values of the goods received by the public. ${ }^{2}$ They are a useful source of information which does not show either entirely, or in detail, the economic activities of the WHW as they might have been put to uses other than the subsidies paid out by the KWHW (or WHW) welfare collections as such.

The war-time Rechenschaftsberichten give no indication of how such funds might have been channelled into other uses such as armaments production, or other war-time aims which were unmentioned and completely unconnected with social welfare measures. Indeed the Rechenschaftsberichten show a responsible use of all incoming monies and it would be difficult indeed to deduce from these that KWHW funds were being used for other purposes, in spite of the fact that Hilgenfeldt made a strong request that his statistical material be

1. Ibid.

2. See.'Rechenschaftsberichten' for years 1934/35, 1942/43, BA, R43ii/564; R36/1007; NS26/261; R43ii/564a; R43/560; NS22/750. 
closely restricted in use. ${ }^{1}$ Nevertheless, a copy of the Rechenschaftsbericht of $1936 / 37$ found its way into the files of the DGT; whether it had been sent there in 1941 or at an earlier date is not clear, but it may be of course that such statistical material was not of the totally restricted type, even though detailed information was contained in the $1936 / 37$ statistical reports. ${ }^{2}$

The winter collections for the KWHW in 1942 were put into operation from the 19th September and this does suggest that some sort of compromise had been reached over the extension of the drives which, in peace-time, had not begun until the month of October. ${ }^{3}$ However, collections for the German Red Cross were not undertaken only in the winter so that, strictly speaking, the KWHW was much longer than the peacetime drive in any case. For example, collections for the German Red Cross were carried out on 23rd May 1943 in the Gau MUnchen/Oberbayern and yielded RM 1,664,298. This was an improvement over the previous year's figure of RM 1,395,264. The city of Munich donated RM 812,776 to the DRK in 1943 as opposed to 699,496 in $1942 .^{4}$ It was calculated by the Gau statistical office of the NSV that an average of 3.13 marks had been donated per household in the Gau for the Red Cross collection. ${ }^{5}$ In 1942, the

1. BA, NS 22/750, Hilgenfeldt to Ley, letter of 8th April 1941.

2. BA, R43ii/564a, 'Rechenschaftsbericht WHW, 1936/37.'

3. See Chapter Three.

4. NS1/285 Folder 1-447, Der Traditionsgau, 'Die Gauleitung Munchen Oberbayern', June 1943, section, 'Gauamt fUr Volkswohlfahrt', p.17.

5. Ibid. 
DRK collections throughout the Reich (street collections), had taken place on the 27 th and 28 th of June that year. ${ }^{1}$ In Hilgenfeldt's request for an extension of the drive for KWHW to raise greater sums of money, he did not refer, specifically to these DRK collections whose funds, as far as can be discovered, were directed as claimed to this agency. However, it might be emphasised that the amounts collected from the people remained as high as in previous years, and there seemed to exist no particular danger that less money was being collected on the streets of the Reich. ${ }^{2}$ The amounts collected in the winter of 1941/42 showed a marked improvement in relation to the sums collected in the previous year. ${ }^{3}$ To Lammers, at least, Hilgenfeldt was prepared to assert, in the face of growing evidence to the contrary, that these figures gave a continuing 'picture' of support for the regime and existed as proof of the Siegeswillens of the people, if such proof were required. ${ }^{4}$ The amounts collected in the KWHW collections were given as follows:

$\begin{array}{ll}1939 / 40 & 680,717,428 \\ 1940 / 41 & 916,240,096\end{array}$

1. HA, 13/261, 'Artikeldienst' 'Zur ersten Strassen-Sammlung im Kriegshilfswerk fur das Deutsche Rote Kreuz am 27. und 28. Juni $1942^{\prime}$.

2. BA, R43ii/560, 'Rechenschaftsbericht 1942/43', amounts for Reich street collections came to RM 294,309,33,p.7; Reich street collections in 1935/36 amounted to RM 18,409,31, BA, NS22 3750, 'Rechenschaftsbericht 1935/36',p.9.

3. BA, NS 26/261, 'Rechenschaftsbericht 1941/42', p.2; BA, R43ii/560 Hilgenfeldt to Lammers, letter of 25th September,1942; the Rechenschaftsbericht for the year $1940 / 41$ has not been discovered but Hilgenfeldt reported to Lammers that the amounts collected during 1941/42 had shown an improvement of 1.2 millions.

4. BA, R4311/560, Hilgenfeldt to Lammers, letter of 25 th September 1942. 


$$
\begin{array}{ll}
1941 / 42 & 1,208,793,752 \\
1942 / 43 & 1,595,743,508
\end{array}
$$

Subsidies to MuK, DFW/Mutterdienst, and Volksgesundheitsdienst were as follows:

$$
1942 / 43
$$

\begin{tabular}{lrr} 
Volksgesundheitsdienst & RM & $25,000,000$ \\
$\begin{array}{l}\text { DFW/Mutterdienst } \\
\text { Muk/other war tasks } \\
\text { relating to MuK }\end{array}$ & RM & $12,000,000$ \\
WHW Subsidies & RM $1,210,982,375$ \\
\hline $1935 / 36$ & $1935 / 41$ \\
$1936 / 37$ & $7,302,000$ \\
$1937 / 38$ & $54,597,000$ \\
$1938 / 39$ & $78,428,000$ \\
$1939 / 40$ & $176,024,000$ \\
$1940 / 41$ & $343,452,000$ \\
$1941 / 42$ & $552,200,000$
\end{tabular}

The lists of Gaus now included in these reports were the Netherlands (listed as Arbeitsbereich i.d.Niederlanden) the General Government, WUrttemberg, Vienna and the other Austrian Gaus. ${ }^{3}$, the Sudetenland too was also in these lists.

The Greater German Reich was now involved in KWHW which would continue to hold street collections and other methods of collection from Opfersonntag to the sale of badges in the streets. 4

1. BA, R43ii/560, 'Rechenschaftsbericht 1942/43', see section VIII, 'Aufkommen der Winterhilfswerk des Deutschen Volkes'.

2. Ibid., p.5; BA, NS 26/261, 'Aufkommen und Werwendung', p.21.

3. BA, R43ii/560, 'Rechenschaftsbericht 1942/43', p.8.

4. Ibid.; See Chapter Three. 
The total amount collected for WHW and KWHW from the years 1933 to 1943 came to RM $6,892,047,000 .^{1}$ This is to say that just under 7 billion marks had been donated by the population of Germany (and in the occupied areas) in a period of ten years to a measure which had begun in an exceedingly modest way for needy Party activists. ${ }^{2}$ By 1943 an average of 2,307,872 families (including single persons) were given aid in each month of the winter in that year which, expressed in another way, meant that 60 individuals per 1,000 inhabitants were given some form of KWHW welfare. This consisted of Wertscheine (vouchers) and some items according to the regulations and availability of goods in time of rationing. ${ }^{3}$ The distribution of aid $1942 / 43$ was calculated as follows:

$\begin{array}{lr}\text { Ausgegebene Wertscheine } & \text { RM 286,941,984 } \\ \begin{array}{l}\text { Sachspenden } \\ \begin{array}{l}\text { Erweitertes Kriegs-WHW } \\ \text { Wertscheine }\end{array}\end{array} & \text { RM } \quad 5,905,000 \\ & \text { RM 308, 182,694 }\end{array}$

A monthly average of 60 KWHW recipients for $1942 / 43$ received grants from the above donations to KWHW.

An examination of the written articles which were included in the 'Artikeldienst' service of the NSV for use in propaganda reveals how sentimental this had become, even though such a stress had existed right from the beginning. Items offered for use included ones whose flights of fancy indicated a retreat from reality, rather

1. Ibid., see section VIII.

2. HA, 14/262, 'Das Winterhilfswerk setzt ein', pp.180-211.

3. BA, R43ii/560, 'Rechenschaftsbericht 1942/43; p.3. 
than an attempt to grasp hold of the task of appealing in time of war for money and for support from the population. An appeal for the second street collections of the DRK in 1940 was given in the form of a curious tale of a dream in which many flowers figured, from bridal bouquets to roses given by someone leaving on a journey. ${ }^{l}$ On waking, the storyteller, (a girl or young woman) awoke to find that thoughts of war had now become connected with thoughts of flowers of all types which are given in farewell scenes and in leave-taking of all kinds. The waking realisation that the father of the girl might never return, 'perhaps, perhaps he will return no more', had set her to thinking that she must go out at the weekend to buy the flowers, 'which would be on sale during the street collections on 22 nd and the 23rd of August 1940, when the HJ the BdM the NSKOV and the Reichskriegerbund, and members of the DRK, would be on duty to sell small articles and artificial flowers to raise money'. However, all this latter information was contained in the same paragraph which told of the 'dream'. This particular article must count as one of the stranger propaganda pieces of the KWHW, given the uncharacteristic mixing of 'fact' and fantasy in such an obviously unsophisticated manner. ${ }^{3}$ Other less sentimentally conceived ones were also meant to be used, and these appealed to the 'sense of duty' which was now in war-time seen to be the giving of support to the soldier at the front by considering, and remembering, the dangers of Bolshevism from which the Germany army at the Russian Front was

1. HA, 13/261, 'Artikeldienst', see 'zur 2. Strassensammlung des Kriegshilfswerkes fur das Deutsche Rote Kreuz', 'Blumen zum Abschied'.

2. Ibid.

3. Ibid. 
protecting the homeland. This particular emphasis would as Berghahn has shown, turn into a virulent anti-Russian 'crusade'. ${ }^{1}$ The propaganda articles of the NSV kept closely indeed to this emphasis and mirrored the conduct of the war. KWHW propaganda was meant to support the expansionist aims of the regime by warning of the danger in which Europe now found itself, which must be combated. ${ }^{2}$ The 'case' for these arguments in the form of dire warnings was presented to the population in NSV/KWHW material, as a simplified outline of the speeches of Hitler, especially of those which were made at the beginning of the KWHW drive. ${ }^{3}$ Such articles were prefaced by statements such as 'are we clear about what the words of the Fuhrer mean?' They then went on the explain the theme of the speech itself. the opening speech of Hitler in 1941 for the KWHW was given such treatment in the 'Artikeldienst' of the NSV, only weeks after the invasion of Russia. ${ }^{4}$ In an article entitled, 'Everyone knows how to fulfil his duty', the theme of the Hitler speech was underlined by drawing attention to the pointed references to the danger which existed from the over-running of Europe by the 'Stalinschen Horden' . 5

The reader was to be made aware of the necessity of always keeping in mind the dangers facing the German nation (and Europe too), 'again and again such dangers must always be before one's eyes'. ${ }^{6}$ No possible mention of the true situation was contemplated in such

1. Berghahn, Modern Germany, p.164.

2. HA; 13/261, 'Zur 2. Reichsstrassensammlung fur das Kriegs-WHW'.

3. Ibid.

4. Ibid.

5. Ibid.

6. Ibid. 
written material which failed to tell of the infamous 'Commissar Order' issued a fortnight before the invasion itself and which allowed that captured Soviet political officials would be shot immediately. ${ }^{l}$ Not only this, but Himmler's Einsatzgruppen, who had followed the conquering army, had been active during the early months of the invasion working with, as Wright puts it, 'deadly efficiency' and no official record of their liquidations seems to have survived. The total divorce between what the NSV now produced in it own propaganda and the reality of the war showed that the manipulation of facts, and actions, even though they were hardly believable in many instances, would create the conditions and opportunities for confusion arising in the minds of many, and perhaps not least in the minds of the NSV officials themselves. ${ }^{2}$ The ability to 'distance' oneself from the true facts of the situation would lead to a 'moral anaemia' developing in the behaviour of officials and other leadership cadres, and not least among the officials of the NSV and KWHW themselves. ${ }^{3}$

At the end of December 1942 Schwarz was forced to raise the matter of the mismanagement of the collections procedures of the KWHW collections by Hoheitsträger and others, at first with Hilgenfeldt and then with Ley. Ley had been contacted in the matter of the use of 'forbidden' measures by DAF Amtswalter and other DAF officials in the collections. ${ }^{4}$ In a letter to Bormann, Schwarz had been relieved to report that Ley had understood the situation but had

1. Wright, The Ordeal of Total War, p.125.

2. Ibid.

3. Ibid., p.126.

4. BA, NS 22/751, Schwarz to Bormann, 'Verbotene Sammlungsmassnahmen von Dienstellen der Deutschen Arbeitsfront anlasslich der von ihr durchgefuhrten Reichstrassensamlung am 24.und 25.0ktober 1942', 15th December 1942. 
expressed the fear that the DAF alone would be left unfairly to shoulder the guilt for the mismanagement of the procedures. Schwarz was deeply worried at this time about the continuing infractions of the collection procedures by leading officials in every Gau, including the Gauleiter. ${ }^{1}$ The infractions consisted of attempts to increase income. by every possible method in order to achieve higher and higher amounts during each drive within the Gaus. ${ }^{2}$ This practice had reached such a point that, simply in the interest of the Party, Schwarz argued, it could no longer be 'calmly considered' for the 'abuses and mis-handling of the collection procedures could only destroy the reputation and the standing of the Party itself in the minds of the people'. ${ }^{3}$ It is not clear whether Hilgenfeldt, who had been in contact with Schwarz at this time, totally agreed with this assessment, but he had been prepared to discuss the matter, admitting that some gross infractions had occurred, but claiming that the collections were still capable of acting as a reliable barometer of public opinion when they were carried out, as he put it, 'honourably'. ${ }^{4}$ However, it seems as though Schwarz despaired of the possibility of making real improvements with regard to the collection procedures, for the infractions had not only been going on for some time, but they were in war-time actually increasing. The problem had emerged mainly because of the tendency of various Gauleiters to use the amounts collected for WHW (and later KWHW) as a sign to the leadership, and Hitler in particular, of their own abilities in

1. Ibid.

2. Ibid.

3. Ibid.

4. Ibid. 
relation to other Gauleiters who might not be managing to produce increased, and increasing, levels of KWHW income. These competitive practices were now held by Schwarz to be utterly unacceptable at this time given that they were proving to be destroying the trust of the people in the regime. As Schwarz explained, he considered that popular opinion was a matter of utmost importance, indeed a top priority which was far more important than the sums collected. In his opinion, the maintenance of favourable popular opinion meant that the leadership must calmly contemplate a reduction of the KWHW income if that was what was required to regularise the collection procedures. ${ }^{l}$ As he pointed out, the 'trust of the people seems to me to be far more important than the results of the collections themselves'. 2 The Gauleiters and other Hoheitsträger were trying to outdo one another year by year, and this accusation could be levelled at Goebbels himself in his role as Gauleiter of Berlin. Hilgenfeldt had privately pointed out to Schwarz in conversation that even he (Goebbels) had been putting pressure on his staff in Berlin, to produce better results. Some Gauleiter had gone so far as to impose punishments on officials in those cases where the single Kreis or Ortsgruppe showed no sign of achieving an increase in the amounts being collected. From this letter it is clear that Hilgenfeldt's goals and those of the Gauleiters were not only unrelated, but the ambitions of these men were totally counter-productive, and even destructive of the aims of the NSV. ${ }^{3}$ Most importantly, Schwarz now believed that most Hoheitstrăger were simply unable to understand the
1. Ibid.
2. Ibid.
3. Ibid. 
situation and did not even know how to gain the trust of the people.

Such a damning criticism of Party functionaries certainly pointed to an urgent reason for finding another way of funding social welfare and other measures, this perhaps, Schwarz himself now realised. ${ }^{l}$ But if it were impossible to impress upon. Party functionaries in the Gaus the importance of allowing the collections to be carried out without coercion being used, then the whole apparatus and practice of the KWHW itself was being called into question. However, Hilgenfeldt himself still seemed to believe that these collections could be carried out 'honorably', ${ }^{2}$ given time, perhaps, or the right type of guidance, this shows that the Reich treasurer and the head of the NSV were quite unable to agree or to understand this problem in the same way. Obviously for Hilgenfeldt, whose reputation came into question in any serious criticism of the KWHW, such a matter was of utmost seriousness. However, no letters from him have so far been discovered on this matter, neither was a copy of the letter from Schwarz contained in the NSV's own files. Through manipulations and irresponsible methods of accounting which could only give a false picture, it seems that the 'sign' of support which the donations to the KWHW were meant to reveal, and had been for some time, utterly worthless. ${ }^{3}$ For this reason it is impossible to use the levels of the sums collected as a sign of anything other than, on the one hand, the application of successful pressure by

\section{Ibid.}

2. Ibid., Schwarz reported that Hilgenfeldt had expressed this view; see also Hilgenfeldt to Lammers, BA, R43ii/560, letter of 25th September 1942.

3. BA, NS $22 / 751$, Schwarz to Bormann, report of 15 th December 1942. 
Party officials or, on the other, a sign of a false and manipulative use of accounting techniques in the Gaus whose responsibility it was to send on their figures to Berlin. As Hilgenfeldt himself pointed out to Schwarz, or was forced to admit, perhaps, in the Gau Salzburg the amounts of the street collections and those of the donations from industry had been shamelessly counted together to give the impression of a larger figure. ${ }^{1}$ However, according to Schwarz at this time, both he and Ley were of the opinion that this matter should be put right, as a matter of the utmost urgency, for if these destructive practices were not halted then finally Hitler himself would have to be brought into the picture so that he could himself perhaps take steps to prevent the continuation of such mistaken methods. ${ }^{2}$ There seems every reason to accept completely Schwarz's accusation of malpractices by Gau staff in the organisation of the finances of KWHW accounting, and in the collection procedures themselves, and there is also every reason to believe that no solution would be forthcoming until the whole organisation and the rationale of collections by donation were entirely changed. It is difficult to see how the regime could have extracted itself from this problem given the endless amount of propaganda which had declared how 'valuable' the winter collections were. However, until further documentation of this particular issue found it is impossible to say further how the NSV itself reacted. Nevertheless, Schwarz's account of Hilgenfeldt's immediate response shows it to have been a remarkably cool one and certainly far less concerned than that of Schwarz's or Ley's. It may

1. Ibid.

2. Ibid. 
have been that problems between Hilgenfeldt and Schwarz, which had emerged in 1942 over the legal and financial affairs of the whole KWHW, had something to do with the raising of this issue at this time. $^{l}$ These problems had arisen over the precise responsibilities of Hilgenfeldt over the finances of the KWHW, which Schwarz believed came under his jurisdiction alone; certainly he had been in charge of these funds since the beginning. A complicated series of discussions in 1942 (at the time of the ten-year existence of the NSV whose anniversary would shortly be celebrated), brought Hilgenfeldt and Schwarz into sharp disagreement, but the issue was resolved through the involvement of Goebbels who allowed that the KWHW finances be left to the NSV to administer, not the Reichsfinanzministerium which would be responsible ultimately for a final reckoning of the accounts. ${ }^{2}$

The KWHW had several functions to fulfil: it had to arrange for the collection of huge sums of money from the population who would not be formally taxed in order to raise much needed revenue, but it had to do it in such a way as to make it seem as though this was not really happening, indeed to give the impression that the people were giving 'freely'. That the KWHW had failed in this particular task was shown by the failure of the Gauleiters and of NSV officials themselves, who put personal ambition before the important goal of preserving popular opinion. ${ }^{3}$ But Hilgenfeldt, it seems, remained convinced of the need to examine and report popular opinion from the point of view of the donation given to the Party's

1. BA, NSl/2259, see correspondence between Schwarz and Hilgenfeldt, July/August 1942.

2. Ibid.

3. BA, NS 22/751, Schwarz to Bormann, 15th December 1942. 
Winter Aid, for this would 'show' how the people really felt about the regime. That his position had become increasingly less tenable was clearly shown by the problems which Schwarz had revealed, and by the destructive practices which he clearly knew about. This included the impossibility of controlling the actions of WHW officials such as one (perhaps not untypical) in Berlin who was prosecuted for carrying on a black market operation in foodstuffs in the city in $1943 .^{1}$ It may be that Hilgenfeldt's continued 'protection' of the continuation of the public collections was no more than a lack of opportunity to do anything else, for it is not clear how the NSV, and Hilgenfeldt in particular, and particularly the Propaganda Ministry itself, could have put stop to the KWHW by raising finances in some other way. By $1942 / 43$ the regime was utterly committed to continuing to use this method of financing certain welfare and other measures, and it would be a hope rather than a certainty that the KWHW would serve as a real barometer of opinion or as a support for the home front. ${ }^{2}$ It certainly seems as though that particular expectation had been abandoned by 1943 when the NSV itself was charged to undertake all rescue work in air-raids and provide all material help for bombed out citizens. ${ }^{3}$ Significantly, there was no mention made of KWHW in the instructions from Goebbels regarding the NSV's new responsibilities

1. BA, R55/1266, 'Feindliche Stimmen gegen die NSV', confidential report of 18th August 1943.

2. BA, NS 22/751, Schwarz to Bormann, 15th December 1942; see also the opening remarks of Hitler at the formal opening of the KWHW 1942/43 which show the continuing stress on support for the home front which should itself support the war effort, see BA, R43ii/560, 'Rechenschaftsbericht WHW 1942/43', p.2.

3. BA, NS 37ii/1011, Reichsministerium fUr Volkssaufklÿrung und Propaganda Interministerieller Luftkreigsschädenausschuss, 'LK-Mitteilung $\mathrm{Nr} 21$ an alle Gau'leiter', 15th August 1943. 
in war-torn Germany. Indeed, the one fairly short reference to the KWHW in the Hitler Order of 1944 came on page six after the introductory statement of the general tasks of the NSV. Within the first section of the Hitler Order came significantly, mention of the 'Mother and Child' operation, which would be seen as the first important task of supporting the home front. In the absence of men in time of war, the NSV would concentrate on the MuK and on its whole child care operation. ${ }^{l}$ To this extent the KWHW was allowed to show honestly perhaps what it really was, namely a means of raising money from the population without using the officially regulated system of taxation. KWHW would go on with its propaganda, but it would increasingly spend more time and effort on the DRK collections so that propaganda would play down the 'hunger and cold' image of the pre-war years. ${ }^{2}$ Where other sections of the NSV grew and flourished in time of war, ironically perhaps, the Winter Aid drives reduced in importance insofar as they existed as a propaganda action. In time of war, more effort and expense would be spent on the Muk which came to supplant the Winter Aid as the regime's most important welfare measure, certainly in the Altreich if not elsewhere. Though the KWHW was carried out in other areas, in the occupied east and elsewhere, it would never again in the Altreich achieve the popularity of the first heady days in 1933/34 when it looked as though many believed, for a few days in the winter at least, in the 'real' existence of the Nazi Volksgemeinschaft when the streets were packed by curious sightseers eager to see the new leaders who were promising to create, in a 'partnership' with the Volksgenossen, the new Social Order. ${ }^{3}$

1. BA, R36/963, 'Verfü'gung $11 / 44$ ', FUhrerhauptquartier, 22nd August 1944.

2. Ibid.; HA, 13/261, 'Artikeldienst', Gll/1041, 1941.

3. See Chapter Three, pp.73-94. 
The war-time activities of the Muk were intended to provide support in the Altreich for those women who would be expected to take on full-time employment, and for those whose husbands had been taken into the armed forces. The wives of soldiers would be encourged by the Party not to worry unduly over any problems and difficulties which they should direct to the NSV's Mutter und Kind advice centres. In East Prussia in 1942, a letter was sent to all soldiers' wives in the Gau to ask them to make more use of the NSV and its Mutter und Kind Section ${ }^{1}$ The Gauleitung urged these women to take their problems, of whatever type or level of difficulty, to the Party itself. One of the functions of the MuK in the war would be not only to provide advice centres for the normal every-day issues of child care, but, in addition, to fulfil the functions of war-time citizens' advice centres designed specifically to aid those mothers who now found themselves alone. ${ }^{2}$ The Gauleiter of East Prussia, with the NSV, arranged that officials deal with all requests coming from soldiers' wives at least eight days after contact with the MuK had been made. At the the very least, they were to provide some form of interim reply until problems could be fully dealt with. The NSV also gave an assurance that such requests would be processed as quickly as possible and there is every reason to believe that such an effort would be made. The NSV in East Prussia had made arrangements for the expected increase in visits from the public and it now included an extra facility in its Königsberg offices, where it would be possible

1. BA, NS37ii/1006, 'Der Gauleiter Ostpreussen, an alle Soldatenfrauen', (?March) 1942.

2. Ibid. 
to visit the office to obtain advice between the hours of $7 \mathrm{a} \cdot \mathrm{m}$. and $1 \mathrm{p} . \mathrm{m}$. and from $3 \mathrm{p} . \mathrm{m}$. to $6 \mathrm{p} . \mathrm{m}$. daily. This information was sent out to those who were likely to need this facility. Importantly, soliders' wives were requested to make contact with the Party, through the NSV, with regard to their problems instead of writing to a soldier husband who was fighting for his country. Soldier's wives were strongly urged to bring 'every issue that worries you' to the offices of the NSV in the future. ${ }^{l}$ Women were told that they should 'write to the Party with all your cares, and the Party itself through the its organisation the NSV Hilfswerk Mutter und Kind, which has undertaken to provide special advice, will help you'. Those particular areas of difficulty in which the Muk would now be prepared to give help and advice were described as follows:

1. Difficulty with family allowances;

2. Worries over a child's education;

3. Children's illnesses;

4. Problems and difficulties over the purchase of food and clothing;

5. Problems with rent or other difficulties with accommodation of whatever kind;

6. Problems over employment for those in full-time work;

7. Pre and post natal care and any problems arising over these. (4)

This fairly comprehensive list of possible areas of concern to many women at this time - ones which might assume gigantic proportions in the absence of a husband at the front - shows how anxious the Muk was

1. Ibid.

2. Ibid. 
to supply a useful service. However, it was with the agreement and cooperation of the Gauleitung in East Prussia as well as the NSV head office in Berlin that this particular list of practical problems had been drawn up, though no instruction coming from the NSV in Berlin has yet been discovered. ${ }^{1}$

That the Muk in war-time was already carrying out a reasonably popular service is seen in the rise in the numbers of visits to Muk clinics between 1939 and 1941. The numbers of visits rose year by year, going from 4,601,511 visits in 1939, to $10,311,121$ in 1941 . The numbers of visits from $1938 / 41$ is shown as follows:

\begin{tabular}{ccc} 
& Clinics & Number of Visit \\
\cline { 2 - 3 } & 25,751 & $3,852,160$ \\
1939 & 32,577 & $4,601,511$ \\
1940 & 33,325 & $7,157,163$ \\
1941 & 28,936 & $10,311,121$
\end{tabular}

The increase in the numbers of visits between 1940 and 1941 meant that $3,153,958_{\text {a }}^{\text {more }}$ Women were attending MuK clinics during 1941. This figure represented over three times as many women visiting a clinic or advice centre than in $1935 .^{3}$ These figures can only mean that the war-time service provided in the clinics was showing itself to be a reasonably popular one, and perhaps showed that the MuK had responded to the changed conditions of war-time Germany by offering a practical and useful service to those who needed advice and help at this time. ${ }^{4}$

\section{Ibid.}

2. BA, NS 26/261, 'Aufkommen und Verwendung', p.26.

3. See Chapter Four, p.148

4. BA, NS 37ii/1006, 'Der Gauleiter an Soldatenfrauen', (?March) 1942. 
In the Gau MUnchen/Oberbayern in 1942, numbers of visits were carefully recorded on a monthly basis showing that, for that particular year, the numbers were recorded to be 8,617 in July, 10,333 in August and 9,119 in September in the 675 Muk clinics in the Gau. ${ }^{l}$ This is to say that the NSV in MUnchen/Oberbayern could expect to record an average monthly number of visits to its Muk facilities of between 12 and 15 visits. In the City of Munich, the numbers of visits to the 113 clinics amounted to between 1,792 and 2,635; thus, the clinics were being visited by between 15 and 23 women per month. This was higher than the average figure for the whole Gau. These figures can be seen as follows:

\begin{tabular}{|c|c|c|c|c|c|c|}
\hline \multirow[b]{3}{*}{$\begin{array}{l}\text { Gau MUchen/ } \\
\text { Oberbayern }\end{array}$} & \multirow[b]{2}{*}{ July } & \multirow[b]{2}{*}{ August } & \multirow[b]{2}{*}{ Sept. } & \multicolumn{3}{|c|}{$\frac{0 \text { Muk, each }}{\text { Mlinic }}$} \\
\hline & & & & July & August & Sept. \\
\hline & 8,617 & 10,333 & 9,119 & 12.76 & 15.30 & 13.50 \\
\hline Munich & 1,792 & 2,635 & 2,104 & 15.85 & 23.30 & 18.60 \\
\hline
\end{tabular}

This is to say that the highest figure for visits to the Munich Muk clinics of $23.30 \%$ was twice the average percentage figure for the Reich in time of peace. ${ }^{2}$

By 1943 there existed just over 30,000 clinics within the Altreich itself and in the occupied areas the Mutter und Kind facilities were being established as quickly as possible, nowhere more successfully than in Hungary, where, though not one of the occupied areas, the NSV, was building up a siziable organisation, the

1. BA, NS 1/285 Folder 1-447, Der Traditionsgau, March 1944, p.374.

2. Ibid.; See Chapter Four, p.148 
most important of which (and the most successful) seems to have been the welfare facilities for mothers and children. ${ }^{l}$ Within the Altreich each Gau had its own specialist medical adviser who was also a member of a Reichsarbeitsgemeinschaft fur Mutter und Kind. ${ }^{2}$ This particular body seems to have been put together as a war-time contingency, for it seems that the existing specialist medical advice arrangements organised by the NSV needed to be expanded at this time (1943). ${ }^{3}$ The members of the Arbeitsgemeinschaft consisted of professors of medicine and doctors including one Gauamtsleiter of the NSV, also a doctor, Dr. Benzing, in Kassel. ${ }^{4}$ But access to such expert advice by MuK clinics was also being provided in the Wartheland and in the Protektorat of Bohemia-Moravia. ${ }^{5}$

There is every reason to believe that Dr. Conti regarded the NSV's Mutter und Kind in a favourable light for he listed this particular welfare facility as having been one of the 'causes' of the fall in the maternal mortality rates from $1933 .^{6}$ Conti showed in 1942 that the fall in this rate had been of a substantial nature, going from 5.3 deaths per 1,000 mothers to 3.5 deaths in 1942 . Child-bed fever had been claiming fewer deaths, though this

1. BA, NS 26/260, 'Rechenschaftsbericht Uber das Kriegswinterhilfswerk des Deutschen Volksgruppe in Ungarn, 1943/44'; Ibid., 'Ukraine' lst November 1943.

2. BA, NS 37ii/1026, 'Gau-Fachberater der Reichsarbeitsgemeinschaft fur Mutter und Kind', ?1943, list of medical specialists in each Gau.

3. Ibid.

4. Ibid.

5. Ibid.

6. BA, R18/3805, 'Stand der Volksgesundheit, p.ll. 
particular development was due not to welfare advice as such but to better management of hygiene and aseptic conditions at the time of a delivery. ${ }^{l}$ Numbers of deaths from this cause had fallen from 1.0 per 1,000 deaths to 0.6 per 1,000 deaths in the period from 1936 to 1940 . However, at this time (1943), Conti was forced to report that this figure was beginning to creep up again due to war-time influences and other difficulties. ${ }^{2}$

In war-time the MuK also received an increased level of participation with the existing Gesundheitsamt of the Party. ${ }^{3}$ It was intended at this particular time in 1941, that the NSV and the Gesundheitsamt would begin to organise facilities from the point of view of a much closer cooperation, not least of which would be the increased participation of the NSV in infant care within the framework of its section MuK. ${ }^{4}$ In time of war, the increase of a preventive health provision such as MuK was regarded as a matter of some urgency, though not, as far as some doctors were concerned, a really welcome development. The prospect of a far closer connection between NSV and Gesundheitsamt brought several problems to the fore which the new regulations of 1941 had not forseen. However, before dealing with the criticisms of this measure it is necessary to outline what the new regulations were designed to provide.

1. Ibid.

2. Ibid.

3. BA, NS $22 / 750$, NSDAP, 'Reichsverfugungsblatt, Anordnung A50/41', Munich, 2nd December 1941.

4. Ibid.; BA, R36/1396, Deutscher Gemeindetag, Reichsgaudienstelle Danzig-Westpreussen, 'Einrichtung und Ausbau von SHuglingsberatungstellen', letter of 18th October 1941. 
On the occasion of an Arbeitstagung of the section 'Gesundheitsamt' of the NSV in May 1942 an opportunity had been taken to discuss these new arrangements. Both Hilgenfeldt and Conti had attended, and both spoke at some length about the new plans, emphasising how important was the need to support working wives and kinderreich mothers during the war. ${ }^{l}$ The new arrangements for a closer cooperition related mainly to the care of infants rather than to increased responsibility for the welfare of expectant mothers. -This set of regulations intended to include the NSV more directly in vital community health care, not unfamiliar to Muk, but it ensured an increasingly, medical, rather than, strictly welfare oriented emphasis. By 1942 it was becoming more noticeable that the NSV was itself becoming more interested and indeed, involved in preventive medicine, as well as in all its other welfare oriented schemes which related closely to the care of the health of very young children especially. ${ }^{2}$ NSV ambitions certainly at this time looked to be pointing in this direction; not only that, but such ambitions were beginning to be realised with the aid of Dr. Conti himself. ${ }^{3}$ New efforts were made to increase all MuK facilities including the important Haushalthilfe scheme which Conti expressly wished to be

1. BA, R36/1396, VB, 'Alle Hilfe fUr Mutter und Kind', article of May 1942.

2. BA, NS 37ii/1010, 'Rundschreiben $\mathrm{Nr} 55 / 43$ ', 'Institut fur nationalsozialistische Volkspflege', 6th April 1943. This was intended to act as a specialist institute which would undertake research and training in three areas: family and people's education and training, people's health care, welfare care and the law.

3. BA, R18/3805, 'Stand der Volksgesundheit', pp.11-13;

$B A, R 18 / 3793$, 'Zur Neuordnung des Gesundheitswesens nach dem Siege', 1943. 
further developed. ${ }^{l}$ To a large extent these developments, coming as they did before the increased bombing raids over Germany interfered with new NSV plans, revealed how the NSV could have expected to grow and develop in the future; and a closer cooperation with the Gesundeitsamt seemed to point the way. ${ }^{2}$ From 1941, the new regulations stated that where the Gesundheitsamt had not itself set up Advice Centres for infant care, the NSV would come in and set these up instead, in order to build up the new cooperative venture. ${ }^{3}$ Medical supervision would be left to the Gesundheitsamt but the NSV would increase its advice/health care facilities in the framework of an increased infant-care scheme. ${ }^{4}$ But the main difference between this new scheme and the older ones already in existence was that the NSV and the Gesundheitsamt would now be expected to work together under a set of previously laid down guidelines which themselves promised a greater degree of possible involvement (or interference, perhaps) in the work of the Gesundheitsamt itself.

Both State officials and medical staff were critical of the new arrangements for they feared that they would only allow complications to arise in the whole organisation of infant care. One doctor at least was reluctant to contemplate the necessity of working with staff not attached to the Gesundheitsamt or in unfamiliar

1. BA, R18/3781, Hilgenfeldt to Dr. Conti 'Hauspflege und Haushalthilfe', letter of 15th November 1939.

2. BA, R36/1396, see Guidelines - Agreement, NSV/Kreisamtsleitung NUrnberg-Stadt, 1941.

3. Ibid.

4. Ibid., Der Vizepräsident des DGT to Fiehler, 'Zusammenarbeit zwischen Gesundheitsamt und Hilf swerk "Mutter und Kind" der NSV', February 1942; Ibid., Der Sasschsiche Minister des Innern, 'Erlass', 15th January 1942. 
surroundings in the NSV clinics. State officials knew that a wasteful, double supply of welfare care would probably arise. In one example a mother had reported to a state welfare official that she had received visits from three NSV aides and one state social welfare worker when the new arrangements came into operation. On the other hand, in Danzig, discussions over the new arrangements had foundered completely and had led to a serious breakdown in the hitherto friendly relations between NSV and Gesundheitsamt. From Salzburg however came the report that the NSV was completely unable to take on

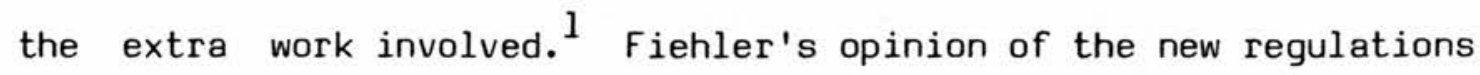
seems to have been that the most painstaking care would have to be taken over the final form of the new regulations in order to avoid the danger of Doppelarbeit.

But these new arrangements only showed the direction of future social welfare/health welfare arrangements which intended that the NSV, and the Office for the People's Health, would cooperate more closely in the provision of general health care for the nation in the future.

War-Time Juvenile Care

From $1942 / 43$, the organisation and the practice of all types of official treatment of juveniles came increasingly to be divided into two separate developments, these were essentially opposite in conception to one another. ${ }^{2}$ These developments were supported by new war-time legislation which had been put into operation as a response

1. BA, R36/1396, from DGT Danzig-Westpreussen to DGT in Berlin, 'Einrichtung und Ausbau von Sauglings beratungsstellen', 18th October 1941.

2. Hasenclever, Jugendhilfe, pp.149-151. 
to increased fears about the need to provide a suitably harsh set of penalties for those young people who showed themselves willing to break the law, or to offend in other ways by coming into conflict with the regime. It is clear that the absence of fathers, who were now in the armed forces, was seen as a potential threat to the stable continuity of development in juvenile behaviour which would, therefore, require to come under the influence of stricter controls. ${ }^{l}$ On the other hand, preventive youth welfare increased, and supportive measures were made available in an 'ellightened' attempt to give aid before too many difficulties might arise.

State juvenile welfare began therefore to make far more use of preventive measures at the same time as highly strict measures of punishments and penalties for various types of juvenile misdemeanours also came into force. ${ }^{2}$ To some extent, the state would be taking a leaf out of the NSVJ book when it began to put into operation a system of 'Erziehungsfursorge' in which the NSVJ itself would also be included. ${ }^{3}$ But the war was the real midwife of such a development, though the example of the NSVJ over some number of years might have helped to suggest this change in emphasis.

An alternative to proposals in 1941 for a greater NSVJ participation in FE selection procedures was found in 1943 through allowing the NSVJ a greater part to play in the new arrangements of the state for 'Erziehungsfursorge ' which would be carried out in an

1. HA, 13/258, 'Artikeldienst', VI/133910, 'Die Mitarbeit unsere Volksgenossen in der NSV-Jugendhilfe ist ebenfalls Dienst an der Inneren Front'.

2. Hasenclever, Jugendhilfe, p.149.

3. Ibid. 
institutional setting. ${ }^{1}$ It would become likely from 1942/43 that the existing Homes of the NSV would be put to increased use, this was something which the NSV (though not the Gemeinde or local government officials) seemed to welcome at the time. From 1939/42, ministerial Orders would set out proposals for new measures so that by early 1942 at least, Hilgenfeldt seemed to be convinced of a new, increasing role for NSVJ homes and facilities. This was clearly shown in February 1942 when he sent out a set of detailed instructions to all the Gaus and the NSV leaders active in them. ${ }^{2}$

However before looking in detail at the instructions of 1942 it should be useful to consider how the work of the NSVJ had been developing from about 1939 with regard to numbers of cases taken up by the Party organisation, for these had been showing a marked tendency to fall. Indeed the NSVJ had been going through what can only be described as a falling off in numbers of cases, and moreover in relation to most of its provisions. It can be seen from the figures given below that the outbreak of war had not significantly increased participation of NSV youth welfare even though war time conditions called for an increased input of the youth welfare services. ${ }^{3}$ To an extent, the NSV had been powerless to promote the cause of its own increased share in the less straightforward cases of juvenile care and it would have to wait for new legal arrangements to

1. BA, R36/1421, 'FUrsorge fur erziehungsbedurftige Minderjahrige (Erziehungsfursorge; Unterbringung in Jugendheimstatten der NSV), RdErl.d.RmdI v.25. 8.43'.

2. BA, NS 37ii/1006, Instructions from Hilgenfeldt to all Leiter 'Hauptstelle Wohlfahrtspflege u. Jugendhilfe', 20th February 1942.

3. BA, NSD 26/261, 'Aufkommen und Verwendung', p.35. 
come from the Interior Ministry itself. ${ }^{l}$ But these did not come forward until $1942 / 43$ at the earliest.

In 1941 the NSV's youth welfare section had been carrying out its various measures in respect of 441,522 young persons of both sexes, that is to say 2,099 fewer than in 1940 and 1,127 fewer than in $1938 .^{2}$ This means that in a period of about four years, from 1938 to 1941, the numbers of cases being taken up had failed to increase in a significant manner, and they had even fallen very markedly between 1938 and 1939 by 38,511 cases. ${ }^{3}$ But this reduction had been taking place at the same time as a growth in numbers of NSV Youth Welfare Homes, which went from 26 in 1936 to 92 in 1941. The numbers of specialist and other staff also continued to increase, going from 34,291 in 1936 , to 141,746 in $1941 .^{4}$ For this reason it seems unlikely that a very serious shortage of NSV helpers or social workers had dictated a drop in numbers of youth welfare cases of the NSVJ. Apart from the continuing high levels of church participation which Althaus at least believed was preventing a greater degree of Party child and youth care from developing, the fall in numbers did not refer to Austria as well, and it would be mistaken to regard such figures as a sign of a decreasing participation within the Greater German Reich itself.

Nevertheless it is difficult to account for such a slow development in NSVJ participation, especially between the years 1938/39, unless every available effort to become established

1. Ibid.

2. Ibid.

3. Ibid.

4. Ibid. 
in Austria had allowed for a reduction of activity within the Altreich. However, it is clear that Hilgenfeldt had decided to make an increased effort to establish his youth welfare organisation at the beginning of 1942 when the signs of a lengthening war made it more likely that youth welfare would increase significantly as events were to show. ${ }^{1}$ Indeed the war proved to have a 'positive' influence on NSV developments, and it would be charged with ensuring that its own provisions for youth welfare would act as a support for the home front. As Hilgenfeldt pointed out, given the changes in the nature of 'family relationships' in time of war, when men were away at the front and women were occupied in the workplace as well as in the home, it would fall to the NSV to supply extra facilities from new kindergartens to increased care for young people. The NSV (and the regime) intended that soldiers at the front would rest assured that the Party had taken every opportunity to provide help for their wives at home, but also for the children whose education and guidance would be given extra care and attention. ${ }^{2}$ In other words, men at the front would be able to forget about their cares over their families and get on with the difficult task of fighting the war. While the emphasis upon fostering the idea of the Volksgemeinschaft did not entirely disappear from NSV rhetoric during the war, it certainly experienced a reduction in importance from 1942/43. NSV activities, especially those of child and youth care came increasingly to stress service for the home front rather than support for the claims of the People's

1. BA, NS 37ii/1006, Instructions from Hilgenfeldt, 20th February 1942.

2. HA, 13/258, 'Artikeldienst' VI/133910, 'Die Mitarbeit unsere Vol.ksgenossen in der NSV-Jugendhilfe ist ebenfalls Dienst an der Inneren Front'. 
Community. ${ }^{1}$ At the beginning of 1942 Hilgenfeldt showed how optimistic he was about a new increase in the work of the NSV-Jugendhilfe section, in the Altreich as well as in Austria where the NSVJ was well established by 1939. After a series of discussions with his Amsleiter, Hilgenfeldt sent a detailed outline of youth welfare activities to every Gau office with the instruction that the NSV Jugendhilfe would, during 1942, be receiving a greater emphasis. ${ }^{2}$ Hilgenfeldt wished to make it known that the Arbeitsplanung for 1942 included the expectation that all NSV Gau officials would be expected to undertake an increased involvement in the NSV Jugendhilfe sections, so that all leading NSV officials were informed that they would be expected to make a greatly increased effort in supporting their own Jugendhilfe sections to achieve a new growth of NSV youth welfare. ${ }^{3}$ Most importantly, Hilgenfeldt instructed that NSV leaders should achieve an effective meshing together of propaganda and practice in every single area of youth care. Instructions would now go out from head office to say that propaganda only made sense, and reached its goal, where the success of practical measures could be guaranteed. Hilgenfeldt was most concerned to warn that extravagant claims of an increased level of participation with the Jugendamter should not be put forward if the NSVJ was not itself in the position to take on extra work. ${ }^{4}$ In other words, care should be taken to be as 'realistic' as possible about the levels of participation which

1. Ibid.

2. BA, NS37ii/1006, Instructions from Hilgenfeldt, 20th February 1942.

3. Ibid.

4. Ibid. 
could be achieved. This paticular instruction showed that Hilgenfeldt had become aware of criticisms of the propensity of the NSV's youth welfare section to offer more than it could deliver, to discredit where it could not provide a remedy, and to organise where activities themselves could not be carried out. ${ }^{l}$ Certainly the instructions of 1942 seems to have been an attempt to combat the effects of the unrealistic promises of earlier years, and to set forth in a spirit of renewed determination to become really effective in what promised to be a climate of increased attention and interest in the youth care of the nation. ${ }^{2}$

The following tasks had to be fulfilled in 1942 and they were set out as follows:

1. Unified training of specialist staff.

2. Intensive explanation of preventive youth care to all Party organistions.

3. Promotion of further developments in every aspect of youth care.

4. Recruitment and training of suitable specialist and other staff.

5. Propaganda advertising the increased NSVJ facilities, to be carried out both through and within the Party, and in newspaper propaganda.

6. The creation of new NSV youth homes and the improvement of the existing ones.

7. Every Gau to have at least two suitable experts for the work of 'educational' training.

1. Ibid.

2. Ibid.

3. Ibid. 
Hilgenfeldt also intended at this time significantly to increase and develop the NSVJ Erziehungsberatungstellen the numbers of which stood at 3,054 in 1941. However it is clear that this particular facility had not been flourishing, for in 1941, there existed fewer of these advice centres for youth care than in 1936, a reduction in numbers which amounted to 307 in all. ${ }^{l}$ It was obvious to Hilgenfeldt that the time was ripe for a renewed attempt to develop these centres which seem to have consisted of a small welfare/advice office, or similar facility, expressly designed for members of the public to approach the NSV on what seems to have been a first time basis. ${ }^{2}$

The NSVJ's war-time activitı did not differ significantly from earlier measures except to the extent in which it was more strictly divided into three essential components going from advice, to full-time care in a home.

The three stages were as follows:

a) Erziehungsberatung (advice to juveniles)

b) Erziehungshilfe (care of a non-institutional type)

c) Erziehungstorge (period of stay in a home) (3)

These activities, which would be set up in a greatly increased way through the provisions of Ministerial Orders of 1942 and 1943, intended that specialist and honorary staff should undertake a three-fold task. Firstly, they had to provide immediate help of whatever type, for it was crucial, especially in war-time, that as

1. BA, NSD 26/261, 'Aufkommen und Verwendung', p.35.

2. BA, NS 37ii/1006, Instructions from Hilgenfeldt, 20th February 1942; see also BA, NS25/1270, VB, article explaining this NSVJ measure, 'Erziehungsberatung', 25 th June 1941.

3. BA, R36/963, article by Hermann Althaus, 'Gegenwartsaufgaben der NSV-Jugendhilfe', in Deutsche Jugendhilfe, April/May 1942. 
little time as possible be wasted between the introduction of a case and its treatment programme. ${ }^{1}$ As Althaus pointed out in his article for the publication Deutsche Jugendhilfe, the NSVJ would expect to put into swift operation its own favourite type of 'early intervention' schemes. They would also emphasise a 'client orientated' treatment rather than a last-resort intervention in the manner which, the NSV said, the state (rather than the Party organisation) tended to favour in its own treatment programmes. The NSVJ made a renewed commitment to early intervention now that they were being promised, through the new regulations, to be more actively involved in institutional care. ${ }^{2}$ Given that the NSV had already taken up a substantial provision of youth welfare in the areas of the Sudentenland and Danzig, as well as in Austria, the NSV leadership looked forward in 1942 to participating more effectively in the Altreich itself. During 1943 however, it soon became clear that local community officials were less than enthusiastic about the proposals for increased NSV participation in welfare work with erziehungsbedUrftige juveniles. Local community officials offered many reasons, during the course of their own discussions of new regulations of 1943, why the NSV might find an increased level of institutional welfare difficult to organise. It was carefully pointed out in the internal discussions of the Ministerial Order of 1943, that the NSV really lacked an adequate number of suitable Homes. On the other hand, the Gemeinden could, and did, provide a 'dichtes Netz' of local community Erziehungsheime. ${ }^{3}$ Certainly, the local community officials feared that a lack of NSVJ institutional

1. Ibid.

2. Ibid.

3. Ibid. 
facilities might introduce the possibility that the NSV itself might be allowed to take on the responsibility for existing Gemeinde Homes in order to fulfil the provisions of the new Ministerial Order of 1943. In other words, if the NSV could prove that it needed existing community facilities to carry out its new responsibilities, then it would be able to assume control over available Homes of the Gemeinde. ${ }^{1}$ This fear was certainly in the minds of state officials, who saw the new regulations of 1943 offering an opportunity for NSV officials to make use of new legal arrangements entirely in their own favour. ${ }^{2}$ Casting around for every possible argument against increasing NSVJ participation, state officials raised again the question of the problem of the 'double' provision of state and Party youth welfare, which interfered with the efficient running of the youth welfare services. ${ }^{3}$ But it can be argued that it was already far too late for such arguments to have any effect, and in any case, they had failed in $1938 / 39$ to halt the NSV advance. State officials were, yet again, struggling over a lost cause, for the NSV was now winning the battle over the youth welfare system even though the conduct of war itself would come to slow down the rate of success. 4 Nevertheless, state officials would try to warn that state and Party facilities and arrangements were not managing to undertake

1. Ibid.

2. Ibid.

3. Ibid.

4. The NSV would assume extra duties in the summer of 1943 through the increased number of evacuations taking place, see BA, NS 37ii/1011, 'LK-Mitteilung $\mathrm{Nr}$. 21', 15th August 1943. 
together an efficient provision of youth welfare. For example, in Steiermark, the organisation of placements had come into serious disorganisation and disarray due to the NSV's practice of making a 'choice' from among the cases which had come forward. Due to the delay caused by the NSV's highly selective procedures, there had proved to be a lack of places in the Gemeinde Homes in Gau Steiermark for those who had been rejected. This meant that neighbouring areas had to be approached in order to find a suitable number of places. Unhappily for the Jugendamter officials, an admission of disorganisition had to be made even though the NSVJ was itself the cause of the resultant over-crowding which occurred in Gemeinde Homes in the vicinity of Steiermark. Understandably, state officials, both before and during the war, deeply resented the manner in which the NSVJ frequently disrupted the youth welfare services instead of supplying them with additional aid. ${ }^{1}$

The basis of objections to the NSVJ still centred around a fear that the selective processes of the NSVJ would prove to be unworkable. However, during the war, it was argued that NSV youth welfare policies were wrongly conceived and based upon such an insufficiently researched understanding of the 'erbbiologische' ideas of the Party as to be practically worthless. ${ }^{2}$ However this was a damning criticism by the DGT of the basis of the Party's own adherence to these ideas, even though it was couched in a critical appraisal of the NSV's youth welfare provisions. ${ }^{3}$ The very nature of the 'partial' or non-statutory care, which was characteristic of

1. BA, R36/1421, 'Verhaltnis zwischen Gemeinden und NSV', 1943.

2. Ibid.

3. Ibid. 
the 'erbbiologische' basis of NSV and youth welfare meant that state officials continued to resent the NSVJ and view it as a semi-serious, not fully professional attempt to become involved in the work of youth care. ${ }^{l}$ Most seriously of all, it was freely admitted that the existing status of genetics did not provide a substantial measure of whether a juvenile could be judged to be capable of developing into a 'worthy' member of the community or not. ${ }^{2}$ As the DGT report to Frick pointed out,

'If the NSV wishes to take on the whole area of Jugendhilfe it will have to do it either with the entire apparatus of the state, or, create one for itself, the extensive duties of the state will have to be taken on by the NSV and its youth welfare section if it seriously wishes to be responsible for this field of social welfare care that is, the care and the protection of the youth of the nation. However, to take on the executive functions of the state can only distance the NSV from the Party itself. In any case, it should be remembered that the Hitler Youth and the state community of ficials have long since undertaken to carry out cooperative work in youth care and the important goals of the $\mathrm{HJ}$ are secured. (unproblematically it is suggested) .... In my opinion therefore, it is entirely unclear why the Dienstellen of the NSV should be in a better position to carry out the tasks of Menschenfuhrung, or be better suited to this task than the state and the community arrangements. In view of the Edict of the Fuhrer, "Vereinfachung der Verwaltung" of 25th January 1942 which expressly forbids, during the war, the undertaking of any work which is unnecessary and which does not serve the war effort, it is essential to leave arrangements as they are. The existing form of the organis'tion of the official/communal youth welfare institutions fulfil their goals adequately already and necessary improvements are already in hand. I consider any major increase by the NSV within this welfare provision to be completely unnecessary. It would on the contrary far from improving the existing facilities only lead to a completely unnecessary disruption for the population in time of war. it must be urged that at least for the duration of the war further developments in this area should be avoided'

1. Ibid.

2. Ibid.

3. Ibid. 
This request which was sent to Frick only weeks before the arrival of Himmler in the RMdI ministerial seat seems not to have been given really serious consideration.

From August 1943, the developments towards a greater NSVJ input into institutional youth care would continue and in December of that year new regulations allowing for a greater degree of participation in all areas of youth care was conceived in relation to a greater degree of cooperation with the Hitler Youth. This was put into operation, covering specific areas from Jugendhilfe to Jugendschutz. ${ }^{1}$ Though not allowing the NSV a free hand with regard to assuming control over every section of the youth welfare system, the legal arrangements of 1943 promised to make the NSV's own section into a force to be reckoned with.in the future and they promised that subsequent changes, should they be made, would be further supportive of the Party agency. However, the conduct of the war would, to a large extent, dictate the speed, and the degree of success of such alterations. However, before looking at the developments of 1944, when the NSV was given increased duties, it is necessary to look at the other war-time development of greater control over the young which was to become a prominent feature from $1940 .^{2}$

Control of Juveniles in the War

After the outbreak of the war it became possible for juvenile offenders over the age of sixteen years to be excluded from the juvenile courts and to be tried in the ordinary courts. ${ }^{3}$ This meant the reversal of measures which had been in existence since 1923 when the juvenile courts had been put into operation and they had been

1. Hasenclever, Jugendhilfe, p.149-151.

2. Hasenclever, Jugendhilfe, pp.151-153.

3. Basic and Zonal Handbooks,: Supplement to Chapter XIV, 'Youth', pp.27-90. 
established to exercise jurisdiction over all offenders between the ages of fourteen and eighteen years. Penalties and educational/ training measures at the disposal of these new juvenile courts were much more flexibly applied than those available to the ordinary criminal courts. Both the Jugendamt and the Guardianship Court had worked closely together with the Juvenile Court, and after 1934 - and to a limited degree - with the NSVJ itself. From 1940 it was possible to impose stricter sentences through the juvenile and criminal courts, and new categories of penalty were brought intoplay, this was clearly shown in the measure Jugendarrest. ${ }^{1}$ The juvenile court would of course continue to impose certain measures such as the ordering of $\underline{\mathrm{FE}}$, or the imposition of a spell in 'ErziehungsfUrsorge' (both measures being first taken up and proposed by the Jugendamt), but it was now possible for the courts to impose a period of confinement which was conceived as a strict disciplinary and educational measure, rather than a simple penalty for a crime. ${ }^{2}$ Jugendarrest was an 'informal' type of arrest which would not recorded in the Strafregister so that the future life of the juvenile would not to come under severe difficulty through the effects of having a criminal record. ${ }^{3}$ Jugendarrest consisted of a spell in detention which could be served on a continuous basis and later, from about 1942 or 1943, during weekends and in other periods of the free time of the offender. The Hitler Youth too were able to impose serious penalties on their members, and in 1941 it was

1. Hasenclever, Jugendhilfe, see, 'Reaktion auf die Kriegsbedingte Gefahrdung der Jugend', pp.148-153.

2. BA, NS $25 / 1270$, VB, 'GemeinnUtzige Arbeit statt Jugendarrest', article of 7 th August 1943.

3. Basic and Zonal Handbook, supplement to Chapter XIV, 'Youth', pp.27-90. 
possible for juveniles to be detained for an indefinite period following an order from the Public Prosecutor for confinement in a Jugendschutzlager where the conditions were harsh indeed. ${ }^{l}$ Camps were constructed to accommodate offenders (one of these being in the vicinity of Ravensbrllck) and the inmates seem to have been aged between 16 and 21 years. These young people had slipped through the preventive welfare net (including the stronger measures of $\underline{F E}$ ) because their perceived anti-social and criminal tendencies had shown them to be in need of police attention. For this reason they were included in criminal, rather than welfare, procedures. ${ }^{2}$ It seems that by 1944 , the police had made application for 1,150 boys and 800 girls to be sent to detention camps under the Jugendschutz category. ${ }^{3}$ However, any incorrigibles who had ended up in FE would now find, during the war, that they would be transferred to one of these detention camps if their behaviour was proving to be insensitive to change. ${ }^{4}$ The official response to the effects of the war, which saw a need to impose firm discipline meant that the juvenile welfare/juvenile court system increasingly came under the influence of a harsh set of penalties as well as an increased set of treatment possibilities. This revealed how anxious perhaps the leadership was in relation to the whole question of dealing with those young people who were showing themselves difficult either to control, or to educate. ${ }^{5}$ But there is no doubt that the regime, in time of war, set
1. Ibid.
2. Ibid.
3. Ibid.
4. Ibid.
5. Ibid. 
itself to find 'solutions'. ' In addition to the arrangements for Jugendarrest a new regulation was put into service when a new law of 2lst December allowed that the measure 'Arbeitserziehung der Jugend' would be put into operation. This measura consisted of a three month spell in total confinement, but where young offenders were put to work which contributed to the war effort. Those who had continued to absent themselves from work, or who could be shown to be in danger of serious neglect through stealing, immoral conduct, etc., were given what amounted to a three month jail sentence so that the new measure was an exceedingly strictly applied form of correctional education. But it seems to have been intended mainly for those cases which did not necessarily come within the category Jugendarrest, or where $\underline{F E}$ and other educational measures were considered to be unsuitable. ${ }^{2}$ As Hasenclever points out, it was a completely 'new' way to treat older, 'endangered' juveniles who were difficult to include within the correctional educational measures in existence at the time. Its precise relationship with Erziehungsfursorge seems to have been that only the very serious cases would be taken into total confinement. The less serious cases would continue to be placed within less punishment-oriented institutional facilities of welfare, rather than into total confinement in camps. ${ }^{3}$ The very complicated system which was being put into operation must have provided something close to a comprehensive list of possible options and alternatives for the treatment of juvenile misdemeanor of many types and categories. The

1. BA, NS 25/1270, VB., 'GemeinnUtzige Arbeit statt Jugendarrest', article of August 1943 .

2. Hasenclever, Jugendhilfe, p.150.

3. Ibid. 
danger must have been that too many different methods of dealing with juvenile delinquency would be counter-productive; but the determination to impose controls whenever the situation seemed to demand it meant that young people would be liable to come into the punishment oriented measures, as well as the welfare oriented ones. In some cases at least it would be a matter of luck whether or not one was sent to the punishment camps or to the training/'educational' establishments of the state and the Party.

Jugendarrest, which had come under scrutiny in 1942/43, seems to have undergone both modification and extension at this time. New regulations promised that those having such a penalty imposed on them would undertake work in their free time and this, it was said, had already shown very 'good' results in Nurnberg. ${ }^{1}$ A modified Jugendarrest gave the opportunity for paying for a less serious misdemeanor in the form of compulsory work for the community which was held to be of great educational value as well as offering an opportunity to do something really useful as a 'payment' for bad behaviour.

Youths were directed to undertake work for the NSV, especially for the NSV's Ernahrungshilfswerk, (NSV garbage collections for pigs) or they would be put to gardening; girls were assigned to work with the NSF, and given the job of mending socks for soldiers. ${ }^{2}$ Girls undertaking a weekend spell of Jugendarrest might also find that they would have to do a stint in one of the NSV's communal kitchen/feeding centres, for these facilities were still in use

1. BA, NS $25 / 1270$, VB , 'Gemeinnutzige Arbeit statt Jugendarrest', article of 7th August 1943.

2. Ibid. 
during the war. ${ }^{1}$ offenders undertook an eight hour week-end work-duty (if a first offender). It seems that the intention existed mainly to limit the longer periods held under Jugendarrest to second, and subsequent, offenders and give the opportunity to first offenders to make amends in the service of a payment to the community by undertaking a period of hard work in their own free time. It was reported that this measure had shown a very low instance of recidivism, and a majority of those who had undergone an initial spell of modified Jugendarrest had carefully avoided the occasion whereby a second, longer period of punishment might be imposed. ${ }^{2}$ Evidently in NUrn berg, this measure had been greeted by both parents and teachers alike and it was being used as much as full Jugendarrest itself and proving to be of much value. It was a measure which offered an opportunity of learning a sense of 'responsibility', in relation to the community in which the juvenile himself was living, indeed it was seen to be a 'volkstUmliche' worthwhile means of dealing with young offenders whose 'crimes' had been relatively minor ones. ${ }^{3}$

While it has been pointed out in one study ${ }^{4}$ that the NSV would eventually take 'control' of the state welfare system, such was not to be the case, even though there was put into force the Hitler Order of 1944 which among other items outlined in detail the

1. Ibid.

2. Ibid.

3. Ibid.

4. Siegel, 'The National Socialist People's Welfare Organization 1933-1939', p.255. 
duties of the NSV's youth welfare section. ${ }^{1}$ But these new regulations allowed only for a consolidation of the gains of 1942/43, not a 'take-over' of the whole juvenile care system itself. The levels of existing state welfare by the end of March 1943 were high indeed and it seems impossible to imagine how the NSV could have assumed control over the whole of the state's youth welfare arrangements without a massive alteration taking place within the complicated political structure of the regime itself.

Reports from state officials over the difficulties of producing their statistical material in war-time shows how the state Jugendamter were still, in 1944, providing an extensive provision of juvenile and child care including the organisation of fostering arrangements for children, the guardianship of minors and many other welfare activities. ${ }^{2}$ Even though NSVJ participation was increasing in certain substantive areas of the juvenile care system, the very nature of this complicated provision promised that the NSV would have to build up a considerable organisation as the state officials had pointed out, before a real Party take-over could occur.

Certainly it was proving more and more difficult to produce statistics relating to the activities of the Jugendamter and the problems for the state officials who had to compile these were made nightmarish by the air-raids which had increased over Germany. ${ }^{3}$ One official in Hanover was forced to report that all his statistical material had been lost in the raids of July 1943 and he now had the

1. BA, R36/963, 'Verfugung $11 / 44$ ', Fuhrerhauptquartier 22nd August 1944.

2. $\mathrm{BA}, \mathrm{R} 18 / 3271$, letter to the Regierunsprassident Hanover from the Wohlfahrtsamt Hanover, 'Reichstatistik über die Tatigkeit der Jugendamter in Rechnungsjahr 1942', 12 th May 1944.

3. Ibid. 
task of starting all over again to produce the figures which would not be ready for some time. ${ }^{1}$ By the beginning of October 1944 there existed in the area of Greater Germany 1,364 Jugendamter which had to make provision for 329,222 Foster Children of whom the majority were illegitimate. But it was feared that the rise in the numbers of legitimate cases being taken into care were entirely due to 'the growing numbers' of mothers now out at work throughout Germany. It was believed by some state welfare officials at least, that such an increase could only be due to this cause, for the numbers of working married women had increased so they thought, quite substantially. However, it has been shown that the numbers of working married women in war-time fell far short of those in the allied countries where the percentage of women out at work, and who had young children, was much higher than in Germany. ${ }^{2}$ The understandable fears of 'neglected' children was a matter which the NSV too considered to be one of great importance. It can be argued that it was these considerations of the needs of children and juveniles in war-time which had eventually ensured the continued growth of the Party agency's youth welfare section rather than a firm realisation by the leadership that the NSV was better able to carry out the duties of youth care than, for example, the Gemeinden. However, by the time of a hoped for victory, the NSV and its youth welfare section would have been in a strong position to assume full responsibility for a powerful Party-based provision from which state participation had been significantly diminished in importance. ${ }^{3}$ But the war itself could not ensure the

1. Ibid.

2. Winkler, Frauenarbeit, p.177.

3. BA, R36/963, 'Verfügung $11 / 44$ ', Führerhauptquartier, 22nd August 1944. 
swift take-over by the NSV of the entire youth welfare system even though the new regulations of 1944 made it look as though this eventually might occur at some later date. That this later date never arrived means that the NSVJ developments can only be examined from the point of view of a growing and strongly based increase from the year 1942, one which did not promise to diminish, though NSV statistics are not available for the year $1944 .{ }^{1}$ The further increase of NSVJ activity was ensured by the Order of Hitler of 1944, and there is every reason to suppose that all youth care would eventually have come under the leadership of the Party, rather than continue as acombination of state and Party activity, in a victorious Reich.

\section{Evacuation/Aid for the Bombed Areas}

In March 1943 the NSV was still considering a set of plans for modified holiday arrangements for young people through the KLV for the coming summer. ${ }^{2}$ In the NSV Haushalt plan of $1943 / 44$ the intention existed that a percentage only of various age groups would be sent away on a KLV trip during the year. ${ }^{3}$ However the intention to to carry on with KLV arrangements came expressly from Hitler, for in December 1942 he had ordered that children who were not living in the Luftgef hhrdeten (bomb-endangered) areas should still be sent away on a KLV trip if parents were agreeable. However no pressure was to be brought to bear if parents refused to take up an offer in

1. BA, R36/1421, see correspondence August-0ctober 1943; see also discussion document, 'Untersuchungen zur Problematik in der Jugendpsychiatrischen Kinik und dem Landesjugendamt der Provinz Oberschlesien', 1943.

2. BA, NS 37ii/1010, Hilgenfeldt to all Gauamtsleiter NSV, Rundschreiben $\mathrm{Nr}$. 40/43, 'Durchfuhrung der Jugenderholungspflege $1943 / 44$;' 9th March 1943.

3. Ibid.; see also Chapter Six p. 280 
the light of war-time conditions. Indeed, one may argue that these arrangements show how highly regarded these schemes were, given the stress being put upon the need to maintain them in the face of obvious difficulty, and even danger. ${ }^{l}$ Hilgenfeldt's instruction, though pessimistic about the numbers which could be taken up, also included arrangements for the older age groups up to the age of twenty-one. ${ }^{2}$ The value to the government of the holiday schemes organised by the NSV, was also reflected in the preparations which were being made in April 1943. Those who were recuperating from injuries received in the air raids would be sent on a holiday within the framework of the Hitler Freiplatz Spende. These holidays would be allowed to those living in DUsseldorf, Essen and Hamburg, and in the Gaus Koln-Aachen, Schleswig-Holstein, Weser Ems, Westfalen Nord and Westfalen Sud. ${ }^{3}$ However these seem to have been the last of the arrangements which would be made in respect of free holidays, for the KLV would be wound down from the summer of 1943 to meet the newly increased arrangements for EKLV and the official evacuation scheme. The NSV dealt with an increasing number of war-time tasks and duties some of which would show the NSV in its best light as state officials had to grudgingly admit. ${ }^{4}$ The first test of the NSV's ability to

1. BA, NS 37ii/1010, Instructions to all Reich Ministers from Dr. Lammers on KLV arrangements during the war, 17th December 1942.

2. BA, NS 37ii/1010, 'Rundschreiben $\mathrm{Nr}$. 40/43', 9th March 1943.

3. BA, NS27ii/1010, 'Rundschreiben Nr. 57/43', 'Erholungsverschickung im Rahmen der Hitler-Freiplatz-Spende', 9th April 1943.

4. BA, NS $25 / 1162$, fol. 1, letter from the Oberburgermeister Stuttgart, to Dr. Steimle, Hauptamt fUr Kommunalpolitik, 13 th May 1942. 
come to the aid of a population after a serious bombing raid, presented itself immediately after the air-raids over the city of Lubeck in the spring of $1942 .^{1}$ At this time the NSV quickly set up an extra headquarters, and proceeded to organise facilities for the care of those who had lost everything in the bombing. Distributions were made of food and clothing, and other essential items such as milk for children. An emergency feeding centre was quickly set up to deal with approximately 3,000 people, and canteen facilities were organised until the city was able to return to normal. During a period of fourteen days in LUbeck, the NSV succeeded in arranging for the distribution of 40,000 loaves of bread, 16,000 eggs, and other quantities of foodstuffs which included, because it was Easter, some chocolate and Easter eggs for families with children. ${ }^{2}$ The provision of aid for those who had been rendered homeless would be one of the main tasks of the NSV after an air-raid, and it would have to make suitable arrangements for emergency canteen/cooking facilities. ${ }^{3}$ These, and other duties, would be undertaken in other cities including Hamburg. ${ }^{4}$ There is good reason to believe, as Arthur Marwick has pointed out, that the German welfare services, including the NSV, showed themselves able to respond efficiently in a

1. Ibid., article in Stuttgarter Neuen Tageblatt,

'Lubeck-Nach 14 Tagen', 2nd June 1942.

2. Ibid.

3. BA, NS 37ii/1011, 'Rundschreiben Nr. 148/43', Hilgenfeldt to all NSV Gauamtsleiter, 'Schaffung von Koch-und Heizgelegenheiten fur Umqartierte bzw, Fliegergeschädigte', 12th August 1943.

4. BA, NS 26/260, report to Berlin 'NSV - Einsatz in den Hamburger Grosskatastrophentagen', 1943. 
desparate situation, nowhere more effectively it seems than in Hamburg. 1

The new responsibilities of the NSV which were outlined by Hilgenfeldt in July 1943 called for significantly increased arrangements for evacuating people from the endangered areas; these would be put into operation right away. ${ }^{2}$ The NSV would be expected to regulate the movement of evacuees who would be given immediate assistance on arrival in the so-called 'reception' areas Entsendegau/Aufnahmegau. NSV workers would be expected to meet the trains of the evacuees and arrange for food to be available, however the practice showed that problems would continually arise, causing much wasted time and effort. After one bombing raid over Berlin the NSV officials in AngermUnde were told to expect 900 evacuees, and to make suitable arrangements. The subsequent arrival of an empty train in the middle of the night greatly angered officials who had to try to dispose of large quantities of food or let it go to waste. ${ }^{3}$ Evidently this was no isolated case and many similar errors in organisation arose to infuriate everyone concerned. ${ }^{4}$ Nevertheless, other war-time duties of the NSV, were also outlined by the Propaganda Ministry in August 1943 through Goebbels'

1. Ibid.; See Arthur Marwick, War and Social Change in the twentieth century, London 1974, pp.114-118.

2. BA, NS37ii/1011, Hilgenfeldt to all leading NSV officials 'Rundschreiben Nr. 133/43', 'Umquartierung Wegen Luftgefahrdung und Bombenschäden', 24th July 1943.

3. BA, NS 26/260, report of Gustav-Adolf Ventner, to NSV Berlin Redner der NSDAP, 'Bericht über meine Reise in die Kreise AngermUnde und Prenzlau vom 2.-19. 12. 1943', 29th December 1943.

4. Ibid. 
Interministerialler Luftkriegsschaddenassschuss. ${ }^{1}$ It seems that all Gauleiters would be contacted through this office in order that there could be a coordination of the information on bombing raids coming in from the Gaus. However, it seems that this did not always run smoothly, and Goebbels had to remind Gauleiters to channel information through this office. ${ }^{2}$ The care of the material needs of evacuees also included the responsibility for coordinating the activities of the other Party organisations, but one of the more important tasks would be arranging in advance for a supply of suitable accommodation which could, if necessary, be used for reasonably long periods. Arrangements for the control of the movements of the evacuees would be made through the system of official reception areas so that each Gauleitung would know exactly how many places were available and in which Gau area, and this system seems to have run fairly smoothly. Given that each Gau had its own allocated reception area, evacuees were sent through a strictly ordered system of travel permits, and this functioned as a means of regulating the billeting of those leaving the towns and cities. 3 official permission to be evacuated had to be obtained even if a private arrangement was made, for a private billeting could only be permitted if arrangements were made with relatives, otherwise, evacuees had to be processed through the official evacuation programme.

1. BA, NS37/1011, to all Gauleiters, 'Reichsministerium fUr Volksaufklärung und Propaganda Interministerieller Luftkriegśhłdenausschuss, LK-Mitteilung $\mathrm{Nr} .21$ ', 15th August 1943.

2 Ibid., instructions to all Gauleiters, 9th August 1943.

3. NS37 ii/1010, NSV to all leading officials, 'Rundschreiben. Nr. 123/43, EKLV', 14th July 1943. 
The city of Berlin for example would send evacuees to Mark Brandenburg which could offer 197,000 places, or to East Prussia where 95,000 places would be made available for Berliners. Hamburg, which needed an unbelievable 1,000,000 evacuation places in 1943 had earlier been allocated 231,800 accommodations; in Schleswig-Holstein $(52,000)$, Bayreuth $(117,000)$, Ost Hannover $(7,700)$, Mark Bradenburg $(15,000)$ and Danzig $(40,000) .^{1}$ The NSV was kept regularly informed about the distribution of the numbers of places, so that on the first of July 1943, there remained for the use of the city of Hamburg 186,384 places given that 45,416 had already been used. ${ }^{2}$ This meant that the official evacuation scheme had to find emergency alternative accommodation for one million people, after the air-raids of July/August that year. ${ }^{3}$ The NSV also organised reception areas after an air raid where the homeless could go while waiting to be sent away, and there they would be given aid and clothing if they, lost all their possessions. While the EKLV (Erweiterte Kinderlandverschickung) scheme would be run by the HJ, the NSV retained its responsibility for younger age groups (children aged up to ten years) and it seems that they also took on the running of evacuation homes for these younger children. However, no information on this practice has been discovered, apart from a brief reference in a British government report. ${ }^{4}$ In the reception areas, the NSV worked with the local authorities, and made arrangements for the financial support of

1. Ibid.

2. Ibid., see 'Anlage', p.l.

3. BA, NS26/260, report to NSV Berlin, 'NSV-Einsatz/Hamburg' 1943.

4. Basic and Zonal Handbook., Chapter VII, p.169-170. 
evacuees through the Räumungs-Familienunterhalt, a support measure which was meant to cover the extra cost of rent and other essential items. But the practice would show that such arrangements did not always go down well with the inhabitants in the reception areas, for they could see that women evacuees were being allowed generous payments for themselves and their accompanying children. ${ }^{1}$ This only created 'bad blood' between the evacuees and the hard-working, poorly paid inhabitants in country areas who knew perfectly well that evacuees were receiving extra payments from the NSV over and above their allowances as soldiers wives. In country areas the sight of women evacuees wearing trousers and make-up aroused a shocked response in many of the locals. ${ }^{2}$ The dislocation of populations created many problems, not least for the indigenous populations in the country areas, the most serious perhaps being the extra pressure brought to bear on the maternity services which could not cope with a huge influx of extra cases in country districts due to a veritable 'Zustrom' of expectant mothers who had been sent into the country from the bomb-endangered areas. ${ }^{3}$

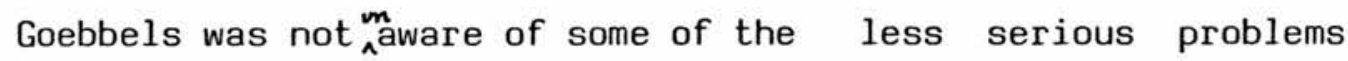
at least, and ordered that recreational facilities should be made available in the reception areas. Every lart, which had a large number of evacuees, was asked to make available a large room or suitable area where the evacuees could meet, listen to the radio or

1. I am grateful to Dr. Jill Stephenson for confirming this.

2. Richard Grunberger, A Social History, p.336, (see note).

3. BA, R18, 378, SD report to Dr. Conti, September 1944. This particular report also included an outline of how difficult it was to encourage more women to have their babies at home in the country areas. 
just get away from cramped living quarters. Goebbels also intended that evacuees should not be left entirely to their own devices at this time, and arranged that one of his senior staff should make a series of arrangements for cultural activities in the evacuation areas for those whose lives had been changed so dramatically. ${ }^{l}$ Most important of all was that access to films and reading material should not be cut off, and great pains were taken by the Propaganda Ministry to supply these. The practice would show, however, that people stayed away in droves from the 'serious' films on offer, and one report suggested that more popular ones really should be made available which catered for a taste in more light hearted themes. ${ }^{2}$ The responsibililty for these cultural activities fell to the Propaganda Ministry, and also the Reichskulturkammer, but not the NSV which would be solely concerned with providing for the material, not the cultural needs of evacuees. The work of aiding the evacuees returned the NSV to its original function and to its earlier concerns, which had originally consisted of providing the most basic help for those in dire need. ${ }^{3}$

These tasks were graphically described by the Hamburg NSV, which was active during the catastrophic bombing raids over the city from the 25th July to the 3rd August 1943. NSV officials there had to come to grips with the failure of their plans to cope with a disaster the size of which had dictated the use of 'blitzschnellen

1. BA, NS37 ii/1011, 'Betreuung der Bombenschadigten und Umquartierten', instructions of August 1943.

2. BA, NS26/260, report to Berlin from AngermUnde/Prenzlau, December 1943.

3. BA, NS37 ii/1011, see 'Rundschreiben 133/43', 24th July 1943. 
Improvisationen'. ${ }^{1}$ Not least of the problems which affected the NSV in Hamburg, was the partial destruction of the Gauamtsleitung and the total breakdown of the telephone connections between that office and the local ones. NSV workers who had tried to make their way to the Gauamtsleitung on the first night had been prevented from reaching it because of the conditions in the streets, these were blocked by rubble, and also panic-stricken people who were trying to make their way out of the areas of the worst disaster. ${ }^{2}$ By the second evening, the NSV was struggling with the need to cope with the results of a serious under-estimation of the numbers of those who would need help and re-housing. The existing 'GK-Plan' had allowed for a possible 50,000 persons rendered homeless or seriously injured, but this figure had grown to almost 250,000 by the night of the 24 th and 25 th July. As the NSV report to Berlin showed, the majority of the Hamburg NSV took part in the rescue operation whether they were honorary workers, or Blockwalter, and whether they were trained or not. ${ }^{3}$ From this report it is seen that an NSV rescue operation after bombing-raids was conceived in three essential parts. Firstly, access to food and drink was secured, and then arrangements to evacuate pregnant women (mothers with children) swiftly out of the areas were made; this particuar measure was urgently carried out in Hamburg, and the NSV managed to move this particularly vulnerable group out of the city by the first of August. Due to this action, there were 1,000 fewer mothers, and 3,00-4,000 fewer children still

1. BA, NS26/260, report to NSV Berlin, 'NSV-Einsatz/Hamburg', 1943.

2. Ibid.

3. Ibid. 
in the city by that though too late to be spared the fire storms which swept the area of the left bank of the Alster on the 28th of July.

There seems little reason to doubt the claims put forward in the NSV report which outlined in detail activities described as having contributed to the saving of many lives; other reports of the Hamburg catastrophe have commented on the speed with which the evacuation of the city was carried through. Indeed the small towns and villages lying in the vicinity of Hamburg were turned into over-crowded 'cities' themselves overnight. ${ }^{1}$

Perhaps the main conclusion of the NSV at this time with regard to the rescue of a civilian population after a bombing raid was the realisation that the emergency plans in Hamburg had failed to allow for the destruction of most of the existing railway stations, and evacuation had been seriously hampered by the fact that no fewer than 15 out of the 18 Hamburg stations had been put out of action during the bombing raids. ${ }^{2}$ It is clear than expectations of damage had, understandably, fallen severely short of the actual event. Indeed, after the Hamburg raid the NSV intended that a new set of plans for cities had to be drawn up at once which would take this into account, and it would have to improve the provisions for raids which might take place in the coming winter of 1943/44; for this reason they would have to think again about all their emergency plans and supplies. The Hamburg report added however, that the spirit of the Volksgemeinschaft (which the Hamburg NSV had not seen much

1. Ibid.

2. Ibid. 
evidence of up to then) had certainly come to the fore in the bombing raids. ${ }^{1}$ This particular comment which really only outlined the futility of the concept of the Volksgemeinschaft, showed that the NSV officials were not able to accept perhaps that there really had been no need to provide years of propaganda and NSV activity in order to encourage the Hamburg population to respond to the conditions of danger and destruction. The people of that city hardly needed to be trained by the NSV to come to the aid of their fellow citizens during the worst parts of the bombing-raids when a spontaneous action was taken, and when many risked their lives in the rescue work. But this does not take away from the value of the effective activities of the NSV which came to the rescue in cities, and other areas, when the tempo of the war increased. Citizens would find that the NSV would be able to help with some of the more urgent needs in time of severe danger.

From 1943 the NSV would continue with the work of evacuation in addition to its other measures the most important of which was the 'Mother and Child' section. The prime position of this particular measure was now reflected in the levels of the KWHW subsidy to the Muk which in 1942/43, amounted to a huge RM 1,210, 982,357. ${ }^{2}$ The participation of the NSV in youth welfare would develop throughout the period, from the beginning of 1942 to $1943 / 44$, promising a significant, future level of Party care for the young. ${ }^{3}$ This was seen in the provisions of the Order of Hitler of 1944 which also

1. Ibid.

2. BA, R43 ii/560, 'Rechenschaftsbericht 1942/43', p. 5.

3. See this Chapter. 
referred to the war-time duties of the NSV, and these were listed as follows:

1. Participation in the EKLV in the work with women and young children up to the age of ten years;

2. Evacuation;

3. The organising of gas-masks for the civilian population;

4. Urgent aid after air-raids;

5. Care of injured persons by providing help with recuperation;

6. All aid for mothers and children;

7. Wehrmachtbetreuung. (Support for the armed forces). This included, the care of all unmarried soldiers on leave to providing facilities in its own institutions for the care of the wounded should that be needed. ${ }^{1}$

But the items in the above list which would take up more of the time and effort of the NSV, would be evacuation and the care of the population after air-raids. From 1944, the reports from the local NSV offices to Berlin showed how the increasing air-raids over the cities of Germany were making it impossible to continue with NSV work, in Darmstadt in September 1944 it was reported to Hilgenfeldt that the NSV Gau office there had virtually ceased to operate. The Gauamstleiter had to report that since the raids of the 11 th and 12 th September, he was unable to say where the majority of his Gau staff were, neither did he know how many had been killed, though this would be reported on as soon as possible. ${ }^{2}$

1. BA, R36/963, 'Verfügung $11 / 44$ ', Fuhrerhauptguartier , 22nd August 1944 .

2. BA, NS26/260, Gauamtsleiter NSV/Hessen-Nassau to Hilgenfeldt, 16 th September 1944. 
From this time there existed a telescoping of the organisation which would, from the end of 1943, increasingly affect the work of the NSV both within the Altreich and in the occupied areas as well. This resembled a two-stage shrinking of the whole NSV operation, at first in the eastern areas such as Hungary (1943), and the occupied areas further west in the Wartheland (the beginning of 1945). ${ }^{1}$ Within the Altreich itself, the telescoping of the organistion would begin in the first quarter of 1944, reaching its most difficult and dangerous point in Frankfurt/Oder at the beginning of $1945 .^{2}$ The activities of NSV staff who were working under the worst possible conditions at the beginning of 1945 seem to have consisted mainly of obtaining fuel for the existing homes of the NSV such as the ones in the area of Darmstadt. ${ }^{3}$ The NSV in Darmstadt sent out what was virtually an S.0.S. to Hilgenfeldt to ask if it might be possible to get help through to the NSV in Darmstadt where fuel was so low that the continued operation of the two NSV maternity homes in the area was now in question. ${ }^{4}$ As the Gauamtsleiter of the NSV put it, 'what use are five tons of coke for one large maternity home? ${ }^{5}$ Many of the NSV Homes in the Gau Hessen-Nassau were now suffering extreme difficulty due to the impossibility of obtaining fuel; existing shortages had been worsened by the destruction of the KBln-Mulheimer

1. Ibid., 'Bericht uber die Ereignisse Mitte Januar 1945', Birnbaum/Wartheland, 30th January 1945.

2. Ibid., see report to NSV from Frankfurt of 3lst January 1945.

3. Ibid., Gauamtsleiter NSV/Hessen/Nassau to Hilgenfeldt, 7 th January

4. Ibid.

5. Ibid. 
bridge which now lay in the Rhein. ${ }^{1}$ From this report and others which were sent to Berlin, it is clear that the NSV, from the beginning of 1945, was closely involved in attempting merely to keep things going as best they could, and to keep their various operations functioning in spite of conditions which were difficult in the extreme. As the Darmstadt report said, they were living a 'hand to mouth existence' at that time, that is to say in January $1945 .^{2}$

In early 1945 in the area of Frankfurt/Oder the NSV had been busy working with all available medical staff to arrange for the control of the flow of populations coming west during January and February 1945, and the NSV itself seems to have been involved mainly in organising aid in the Frankfurt railway stations by providing facilities for mothers and their small children. ${ }^{3}$ The NSV officials were, in early 1945, having to deal with the tragic spectacle of their own people fleeing from eastern Germany instead of with French, Belgian and other refugees, as they had in $1940 .^{4}$ No doubt the experiences of the earlier relief actions had been of some help in organising the flow of refugees in 1945. But it would be this task that the NSV would undertake as one of its last duties in the service of the population of Germany. According to the Frankfurt report from Dr. Syrie, the work of the NSV in the area at this time had been most valuable, with medical staff they had seen the end of the flow of the refugees going west and reported that virtually all the women and

1. Ibid.

2. Ibid.

3. Ibid., see report to NSV from Frankfurt of 3lst January 1945.

4. Ibid. 
children under six years had left the city at this time. ${ }^{l}$ The NSV was also involved in the evacuation of patients from the hospitals in the city which were to be emptied and made available for the military. However, the NSV which was increasingly involved in such work did not always manage to be efficient, for unlike the reports from Frankfurt/Oder, the description of the evacuation of Kreis Birnbaum in Wartheland, also at the beginning of 1945 , showed a less efficiently organised control of refugees which could be better described as a disaster, according to a Volkspflegerin of the Mutter und Kind in Birnbaum. ${ }^{2}$ Evacuation of the Wartheland was, it seems, the responsibịlity of the NSV there, and plans had been made for moving the Volksdeutsche out of the whole area in two stages; from the eastern areas first and from the western areas later, when the situation might demand it. ${ }^{3}$ However, as the Birnbaum report showed, plans had failed almost entirely to cope with the situation so that the whole operation had resembled a . rout with slow-moving columns of women and children ${ }^{4}$ finding themselves in a desperate situation through the lack of proper instructions on how best to move through the area. Evidently many had been trapped in no-man's land; this particular thought was the one which gave the NSV Volkspflegerin who was accompanying these refugees the most regret. Indeed she described the whole experience as one which would stay with her for the rest of her life, as well as the memory of the inefficiency of the officials in the Kreis offices who had allowed such a situation

1. Ibid.

2. Ibid., 'Bericht/Birnbaum/Wartheland', 30th January 1945.

3. Ibid.

4. Ibid. 
to arise in the first place. ${ }^{1}$

The report, which was made by this particular NSV worker on her return to Berlin, might stand as an epitaph for the whole NSV enterprise, not only in Germany, but especially in the east, where high ambition had provided the conditions whereby the reality of a possible loss of the war would make itself known only at the last moment in increasingly endangered NSV operations such as Birnbaum in Wartheland. ${ }^{2}$ The final comment on the whole NSV adventure in the former Poland was, 'that is the end of the work of an NSV Volkspflegerin of the NSV'. She added, nevertheless in spite of all the difficulties in Berlin, further help would be given when needed for it showed that now it was nothing less than a matter of Germany.

1. Ibid.

2. Ibid. 


\section{Postscript}

The German defeat in 1945 brought an end not only $y_{A}$ the Nazi regime but to the organisations of the NSDAP including the NS-Volkswohlfahrt. However, it can be seen that the influence of the more 'positive' NSV welfare policies did not disappear entirely, for the Federal Public Assistance Act (excluding all other NSV emphases), nevertheless includes in its description of the function of public assistance the statement that 'a person who ... does not receive sufficient assistance from other quarters, has a right to personal and financial assistance ... this assistance being of the nature that, most importantly, enables him, as far as possible, to help himself to participate in the life of the community and to lead a life worthy of his membership of the community of Man'. ${ }^{1}$ After the war the private organisations for social welfare came again to flourish, not least of these being the organisations of the churches, Caritas and the reorganised (1957) Diakonisches Werk der Evangelischen Kirche in Deutschland e.V. New private organisations and associations for the support and the welfare of the physically and mentally handicapped were created after the war, including many others, so that the freedom of private welfare organisations to operate, which had entirely disappeared between 1933 and 1945, was fully restored. ${ }^{2}$

An assessment of social welfare in the Nazi period is complicated by the particular form of the Nazi system which existed as a two-fold supply coming from state and Party. Nevertheless, many

1. Franz Flamm, The Social System and Welfare Work in the Federal Republic of Germany, Frankfurt 1980, p.16l.

2. Ibid., see 'Social agencies in the private sector', pp.123-137. 
individuals were excluded from the social welfare provisions, of the Party mainly, but also, in many instances, of the state's as well. Others would find that some aid from the Winterhilfswerk might be the only welfare aid which would be available from the NSV. But the selection of 'worthy' cases would dominate entirely the provisions of Party welfare.

There is good reason to believe that the existence of the NSV, dominated as it was by ideological concerns, would have brought about the complete split in the welfare system in the Altreich, as state officials had feared, after a German victory. While in the occupied areas the NSV swiftly gained a total monopoly, in the Altreich it would have had to wait for some time before a similar situation might emerge. Inevitably the difficult issue of the funding of social welfare would have needed to be solved: in order that a Party take-over of social welfare could have occurred. An answer to this particular problem would also have needed to be found in a victorious Reich.

An assessment of Party welfare as it was provided by the NSV is similarly complicated by problems which were not primarily those of the NSV. These were never solved by the leadership, most notable being the lack of a coherent social policy which would have perhaps clarified earlier the role of the NSV. Instead, the NSV was forced to improvise and manipulate a way through the existing system of welfare without any clear ideas about the true intentions of the leadership. The improvisatory nature of some of the NSV's practices was a reflection of the ill-thought out policies of the Nazi government itself, which left the system of welfare to function as best it could with regard to the double provisions of the state and the Party. But the NSV was both backward looking and forward looking 
at the same time. Apart from a 'modern' orientation in child-care, it looked into the past for inspiration, to the earlier system of social welfare in Germany, the so-called 'Elberfeld' system which had used honorary social welfare workers to provide aid for the population. $^{l}$ Indeed the NSV sought to return social welfare practices to this type, partly as a solution to the problem of funding - to keep down costs - but mainly in response to an ideological commitment to the idea of the value of voluntary unpaid labour by members of the Volksgemeinschaft. However, the NSV also depended heavily upon state subsidies, and there seems to have been every intention to continue funding Party welfare through a difficult to administer mixture of state subsidies and private donation. This was in spite of the problems which had emerged during the war with regard to the collections procedures during the WHW drive in 1943. Schwarz, and possibly Ley, felt that another way of funding Party welfare would need to be found, although the NSV leaders themselves seemed not have considered this to be necessary. Hilgenfeldt had no intention of making changes in the Winter Aid drives, committed as he was to asking directly for funds from the public through a propaganda measure.

In 1940, Guillebaud pointed out that there was nothing to be gained by reducing a description of Nazi Germany to a 'simple' picture of a vast population deluded and oppressed by a small minority of brutal gangsters. ${ }^{2}$ While he did not deny the actual existence of a repressive regime, he cast doubt, as others have done

1. This particular development was deeply deplored by state officials who rightly saw it as just one more example of NSV measures which came into direct conflict with those of the state. Inevitably many state social welfare workers would have lost their jobs if this had been widely adopted, not only by the NSV, but by the state as well.

2. Guillebaud, The

Social policy of Nazi Gernany, p.118. 
since upon the notion of a vast majority being coerced and 'persuaded' by propaganda into accepting the claims of the leadership. Whether or not the NSV, and most notably the Winter Aid, managed to 'persuade' a significant number of Germans of the value of trying to build the new social order is open to question. But the NSV took very seriously the responsibility of assuming a leading role in the care of the very young. Increasingly, from 1941 the NSV was in a position to mould the opinions and guide the development of young children; indeed it would take control (with the $\mathrm{HJ}$ ) over many of the aspects of 'secondary' socialisation.' The continuing development of the NSV's child welfare measures would ensure that social welfare in Germany would mirror the evil tendencies of the regime; without doubt it would have continued to do so, given the opportunity, after a victorious war.

1. This is not to argue that the NSV would find it to be an easy task to mould opinions and attitudes, but that it had at least from 1941 an increasing opportunity to do so. See Chapters Six and Seven. 
A. MANUSCRIPT SOURCES

1. Bundesarchiv Koblenz

Files of:

Amt fur Volkswohlfahrt

NS 3711

Reichsschatzmeister

NS 1

Adjutant des FUhrers

NS 10

Reichsorganisationsleiter

NS 22

Hauptamt fUr Kommunalpolitik

NS 25

Hauptarchiv

NS 26

Reichsfinđzministerium

R2

Reichsministerium des Innern

R 18

Deutscher Gemeindetag

R 36

Reichskanzlei (post-1933)

R 43ii

Reichspropagandaministerium

R 55

Informationsdienst fur die soziale

NSD 30/11

Arbeit der NSV

Periodicals of the NSV

NSD $30 / 3-4 a$

2. Berlin Document Center

Selection of personnel files: all filed under names

3. NSDAP Hauptarchiv - Hoover Institution of War, Revolution and Peace, Stanford University, Stanford, USA.

Reel 13, Folders 258-260

Reel 14, Folders 261-262

Select list of files consulted in the Bundesarchiv Koblenz:

NS 3711 - Amt fur Volkswohlfahrt, 1001-68

This large collection of documents contains much routine correspondence as well as more useful material. The collection is divided up as follows: 


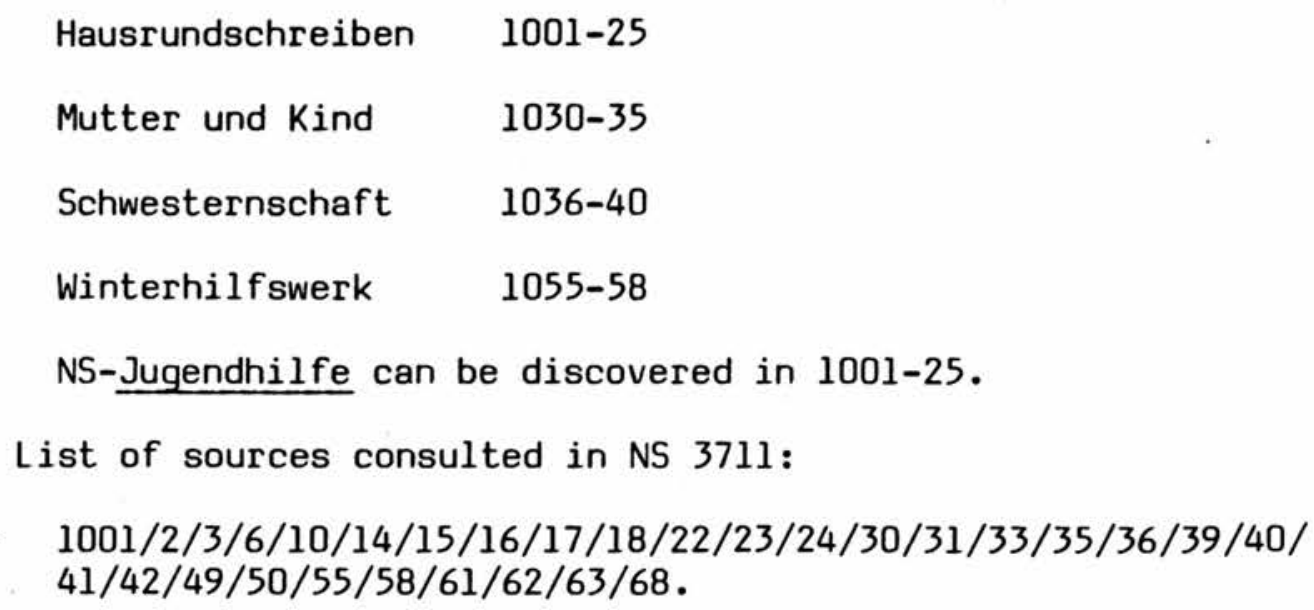

\section{Bundesarchiv}

Reichsschatzmeister NSl:

$\mathrm{NSl} / 10,59,60,64,65,66,67,283,285,300,420,493$, $2259,2520$.

NS10/59/60/64/65/66/67.

Reichsorganisationsleiter NS22:

NS22/132, 358, 457, 650, 653, 656, 713, 746, 747, 748, 750, $751,2010$.

Hauptamt fUr Kommunalpolitik NS25:

NS25/120, $121,122,124,125,126,173,405,482,489,490$, $491,655,680,732,980,1022,1025,1055,1068,1084,1110$, $1147,1148,1149,1152,1158,1161,1162,1199,1233,1265$, $1270,1657$.

Hauptarchiv NS26:

NS26/260, 261.

Reichsfinanzministerium R2:

$\mathrm{R} 2 / 4867$

Reichsministerium des Innern R18:

R18/2969, 2972, 2983, 2993, 3033, 3041, 3042, 3045, 3046, $3047,3062,3064,3081,3084,3247,3249,3251,3259,3269$, $3271,3759,3781,3786,3787,3792,3793,3794,3797,3805$, $3806,3814,3816$.

Deutscher Gemeindetag R36:

$\mathrm{R} 36 / 962,963,964,968,969,970,973,974,979,1001,1002$, 1003, 1007, 1008, 1009, 1069, 1149, 1178, 1209, 1232, 1418, 1421, 1442, 1451, 1457, 1987, 1996, 1997. 
Reichskanzlei (post-1933) R43II:

R43ii/560, 564, 564(a).

Reichspropagandaministerium

R55/103, 452, 1266.

B. PRINTED SOURCES

1. NSV/WHW Reference Works

Altgelt, Ingeborg, Wegweiser durch die NSV, Berlin 1935.

Althaus: Hermann, Nationalsozialistische Volkswohlfahrt, Berlin 1937.

Althaus, Hermann (ed.), Social Work and the Community A Contribution for the III International Conference on Social Work, London, 1936, Karlsruhe 1936. Deine Arbeit:Dein Werk,Berlin 1942. Report of the III International Conference on Social Work London, 1936

Herbst, Kurt, Die NSV dient der Volksgemeinschaft, Breslau 1939.

Hilgenfeldt, Erich, printed speeches: Idee der National-sozialistischen Wohlfahrtspflege, Berlin 1937; Aufgaben der nationalsozialistischen Wohl fahrtspflege, Berlin 1937.

Informationsdienst fur die soziale Arbeit der NS-Volkswohlfahrt, Berlin 1938.

Leistungen der nationalsozialistische Wohlfahrtspflege, MUnchen/Berlin 1937.

Nationalsozialistische Volksdienst: Organ der NS-Volkswohlfahrt, Berlin 1933.

Die NS-Volkswohlfahrt als Kulturtrăgerin, Munchen 1938.

Schule fur das Leben, ein Beruf in der NSV, Berlin n.d. (?1938)

St8rmer, Helmut, Das rechtliche Verhaltnis der NSV und WHW zu den Betreuten im Vergleiche zur $8 \mathrm{ffentlichen}$ Wohlfahrtspflege, Berlin 1940.

Sozialismus der Tat - Das Buch der unbekannten Kämpfer der NSV Berlin, Amt fUr Volkswohlfahrt, Gau Gross-Berlin 1934, Berlin 1934.

Winterhilfswerk des Deutschen Volkes: Allgemeine Arbeitsanweisung: Der Reichsbeauftragte fUr das WHW, Berlin 1936. 
Reher, Werner, Social Welfare in Germany, Berlin 1938.

2. Reference Works

Baynes, Norman H., (ed.), The Speeches of Adolf Hitler 1922-39, Oxford 1942.

Boberach, Heinz (ed.), Meldungen aus dem Reich, Auswahl aus den geheimen Lagerberichten des Sicherheitsdienstes der SS 1939-44, Munich 1968.

Domarus, Max (ed.), Hitler, Reden und Proklamationen, WUrzburg 1962.

Heyen, Franz J., Nationalsozialismus im Alltag. Quellen zur Geschichte des N.-s.vornehmlich im Raum Mainz-Koblenz-Trier, Boppard am Rhein 1967.

International Military Tribunal, NUrnberg, Nazi Conspiracy and Aggression, Washington 1946-47.

Institut der Deutschen Arbeitsfront,

Arbeit Volk und Staat, Auszuge aus Reden Erklarrungen und

Aufsatzen, Berlin 1938.

PEP (Political and Economic Planning) Report on the British Social Services, London 1937.

Reichsorganisationsleiter, Organisationsbuch der NSDAP, Munich 1937.

Statistische JahrbUlcher fur das deutsche Reich, 1933-38.

Trevor-Roper, Hugh (ed.), Hitler's Table Talk, London 1953.

3. Newspapers/Periodicals

Volkischer Beobachter 1933.

Westdeutscher Beobachter

Der Angriff

Ewiges Deutschland, Monatschrift fur den deutschen Volksgenossen, 1936-1939.

Der Traditionsgau: Die Gauleitung MUnchen-Oberbayern, 1942-1943.

4. Pamphlets

Alverdes, Paul and von Medow, Karl, Das Innere Reich. Zeitschrift fur Dichtung Kunst und deutsches Leben, Munchen 1935.

Kaiserberg, G., and Medicus, F., Das Recht der Nationalen Revolution Heft 5, Berlin 1933. 
Krieck, E., Volk Im Werden Heft 3

Zeitschrift fur Kultur politik, Leipzig 1939.

Muckermann, H., Rassenforschung und Volk der Zukunft, Berlin 1932.

Opfermann, A., Volk und Welt, Hanover 1936.

Stockfisch, H.H., Vom Vater habe ich die Statur

Erbgesundheitspflege fur Schule und Volk,

Berlin/Leipzig n.d.

C. SECONDARY SOURCES

1. Articles

Stephenson, Jill. 'Women's Labor Service in Nazi Germany', in Central European History, Vol. XV, No. 3, September 1982.

'"Reichsbund der Kinderreichen": The League of Large Families in the Population Policy of Nazi Germany', in European Studies Review, Vol. 9, 1979.

'War and Society in WUrttemberg, 1939-1945:

Beating the System', in German Studies Review, Vol. VII, No. 1, February 1985.

' "Verantwortungsbewusstsein", Politische Schulung durch die Frauenarganisationen im Dritten Reich', aus Manfred Heinemann (Hrsg.), Erziehung und Schulung im Dritten Reich, Stuttgart 1980.

Unger, Aryeh L. 'Propaganda and Welfare in Nazi Germany', in Journal of Social History, Vol. 4, No. 2, 1970-71.

de Witt, Thomas, 'The Economics and Politics of Welfare in the Third Reich', in Central European History, 1978.

Webster, Charles, 'Healthy or Hungry Thirties' in History Workshop Journal, Vol. 13, 1982.

\section{Dissertations}

Buchholz, Wolfhard, 'Die Nationalsozialistische Gemeinschaft "Kraft durch Freude". Freizeitgestaltung und Arbeitschaft im Dritten Reich', University of Munich, 1976.

Caplan, Jane, 'The Civil Servant in the Third Reich', University of Oxford, 1974.

Ehrhardt, Johannes, 'Erziehungsdenken und Erzie'iungspraxis des Nationalsozialismus', Freien Universitat, Berlin 1968. 
Mason, Timothy, W., 'National Socialist Policies towards the German Working Classes 1925-1939', University of Oxford 1971.

Mennecke, Kurt, 'Ein Westdeutscher NSV Kreis:seine Entstehung und sein Menschengefuge vom 15.September 1933 bis zum

30. November $1934^{\prime}$, University of Cologne 1936.

Stephenson, A. Jill R., 'Women in German Society 1930-1940', University of Edinburgh, 1974.

Siegel, M., 'The National Socialist People's Welfare Organisation 1933-1939; The Political Manipulation of Welfare', University of Cincinnati 1976.

de Witt, Thomas, 'The Nazi Party and Social Welfare 1919-1939', University of Virginia 1972.

3. Published Works

Allen, William Sheridan, The Nazi Seizure of Power - The Experience of a single German Town, New York 1973.

Arendt, Hanna, The Origins of Totalitarianism London 1958.

Baron, R., and Landwehr, R., (Hrsg.), Geschichte der Sozialarbeit, Basel 1983.

Berger, Peter L., and Luckman Thomas, The Social Construction of Reality a Treatise in the Sociology of Knowledge, Baltimore 1966.

Behrens, Manfred (ed.), Fachismus und Ideologie 2 , Berlin 1980.

Berghahn, V.R., Modern Germany, Society, Economy and Politics in the Twentieth Century, Cambridge 1982.

Berghahn, V. and Kitchen, M. (eds.), Germany in the Age of Total War, London 1981.

Blau, Peter, M., The Dynamics of Bureaucracy

A Study of Interpersonal Relationships in Two Government Agencies, London 1955.

Boyd, William, Evacuation in Scotland: A Record of Events and Experiments, London 1944.

Bracher, Karl Dietrich, The German Dictatorship. The Origins Structure and Effects of National Socialism, London 1971.

Bramson, Lean and Goethals, George W. (eds), War- Studies from Psychology, Sociology, Anthropology, London $1 \overline{964 .}$

Bramsted, Ernest K., Aristocracy and the Middle Classes in

German Social Types in German Literature 1830-1900, Chicago 1964 .

Bramsted, Ernest K., Goebbels and National Socialist Propaganda 1925-45, Michigan $196 \overline{5}$. 
Brózat, Martin, The Hitler State: The Foundation and Development of the Internal Structure of the Third Reich, New York 1981.

Bullock, Alan, Hitler: A Study in Tyranny, London 1952.

Carroll, Berenice, Design for Total War: Arms and Economics in the Third Reich, The Hague 1968.

Conway, J.S., The Nazi Persecution of the Churches 1933-1945,

London 1968.

Conze, W., Der Nationalsozialismus, Heidelberg 1962.

Dahrendorf, Ralf, Society and Democracy in Germany, Munich 1965.

Darmstaedter, F., Bismas.k and the Creation of the Second Reich, London 1948.

Dodd, William E., Ambassador Dodd's Diaries 1933-1938, London 1944.

Dodd, Martha, My Years in Germany, London 1939.

Evans, Richard J.,(ed.), Society and Politics in Wilhelmine, Germany, London 1978.

Evans, Richard J., The Feminist Movement in Germany 1894-1933, London 1976.

Evans, Richard J., and Lee, W.R. (eds.), The German Family.

Essays on the Social History of the Family in 19th and 20th Century

Germany, London 1981.

Flamm, Franz, The Social System and Welfare Work in the Federal

Republic of Germany, Frankfurt 1980.

Friedlander, W., and Myers, E.D., Child Welfare in Germany before and after Nazism, Chicago, Illinois 1940.

Glass, D.V., Population Policies and Movements in Europe, Oxford 1940.

Goebbels, Joseph, The Early Goebbels Diaries 1925-26, London 1962.

Goebbels, Joseph, TagebUcher 1945

Die Letzten Aufzeichnungen, Hamburg 1977.

Goldthorpe, John, et al, The Affluent Worker: Industrial Attitudes and Behaviour, Cambridge 1969.

Goering, Hermann, Germany Reborn, London 1934.

Grant, Madison, The Passing of the Great Race, The Racial Basis of European History, New York 1916.

Gregg, Pauline, A Social and Economic History of Britain 1760-1970, London 1971. 
Gregg, Pauline, The Welfare State An Economic and Social History of Britain 1945 to the present day, London 1967.

Grill, J.H., The Nazi Movement in Baden 1920-45, London 1983.

Grunberger, Richard, A Social History of the Third Reich, London 1971.

Grusky, 0., and Miller, G. (eds.), The Sociology of Organisations: Basic Studies, London 1970.

Guillebaud, C.W., The Social Policy of Nazi Germany, Cambridge 1940.

Haarer, Frau Dr., Die Deutsche Mutter und ihr erstes Kind, Munich 1944.

Hasenclever, Christa, Jugendhilfe und Jugendgesetzgebung seit 1900, Gottingen 1978.

Hiden, J., Explaining Hitler's Germany:

and

Farquarson, J., Historians and the Third Reich, Totowa 1983.

Hagermann, Gustav, Germany's Care of the Old and Feeble, Berlin 1941.

Hitler, Adolf, Mein Kampf, Munich 1936.

Hitler, Adolf, Hitler's Zweites Buch; ein Dokument aus dem Jahr 1928, Stuttgart 1961 .

Issaacs, Susan (ed.), The Cambridge Evacuation Survey, A war-time survey in Social Welfare and Education, London 1941.

Kater, Michael H., The Nazi Party, A social profile of Members and Leaders 1919-1945, 0xford 1983.

Kershaw, Ian, Popular Opinion and Political dissent in the Third Reich: Bavaria 1933-1945, Oxford 1983.

Knodel, J.E., The Decline of Fertility in Germany, Princeton 1974.

Krebs, A., The Infancy of Nazism, New York 1976.

Lane, B., et al, Nazi Ideology before 1933 a Documentation, Texas 1978.

Larkin, Maurice, Gathering Pace - Continental Europe 1870-1945,

London 1969.

Laqueur, Walter, Weimar - A Cultural History 1918-1933, London 1974.

Lee, W.R. (ed.), European Demography and Economic Growth, New York 1979.

Lewy, Guenter, The Catholic Church and Nazi Germany, London 1964.

Lutz, K., Biologisches Quellen - und Lesebuch, Munich 1941. 
McCleary, G.F., The Maternity and Child Welfare Movement, London 1935.

Mann, Thomas, Doctor Faustus, London 1983.

- $\quad$ - Diaries 1918-1939, London 1983.

Manvell, R., and Frankel, H., Doctor Goebbels; his life and death, London 1960.

Marwick, Arthur, War and Social Change in the Twentieth Century, a comparative study of Britain, France, Germany, Russia and the U.S.A., London 1974.

Mason, Timothy, W., Sozialpolitik im Dritten Reich Arbeiterklasse und Volksgemeinschaft, Opladen 1978.

Milward, Alan S., The German Economy at War, London 1965.

The New Order and the French Economy, Oxford 1970.

The Facist Economy in Norway, Oxford 1972.

Mommsen, Hans (ed.), The Emergence of the Welfare State in Britain and Germany, London 1966.

Mosse, George L., Nazi Culture, Intellectual, Cultural and Social Life in the Third Reich, London 1966.

Nicholls, A., and Matthias, E.(eds.), German Democracy and the Triumph of Hitler, London 1971.

Nisbet, R.A., The Sociological Tradition, London 1970.

Nolte, Ernst, Three Faces of Fascism, Action Francaise, Italian

Fagcism, National Socialism, Munich 1965.

Open University Course Team 'Understanding Society' (eds.), Understanding Society, London 1970.

Orlow, Dietrich, The History of the Nazi Party: 1919-1933,

Pittsburgh 1969.

- - The History of the Nazi Party: 1933-1945, Pittsburgh

1973.

Rauecker, Bruno, Social Policy in the New Germany, Frankfurt 1936.

Rauschning, H., Germany's Revolution of Destruction, London 1939.

Reulecke, D., und Peukert, J. (Hrsg.), Die Reihen fast Geschlossen. Beitrăge zur Geschichte des Alltags unterm Nationalsozialismus, Wuppertal 1981.

Robertson, Esmonde M. (ed.), The Origins of the Second World War, London 1971. 
Rose, A.M. (ed.), Human Behaviour and Social Processes an interactionist approach, London 1962.

Rosenberg, A., The Birth of the German Republic, 1871-1918, London 1931.

A History of the German Republic, London 1936.

Schirer, William, L., The Rise and Fall of the Third Reich, London 1960.

Schoenbaum, David, Hitler's Social Revolution: Class and Status in Nazi Germany 1933-39, London 1967.

Sleeman, J.F., The Welfare State; its aims, benefits and costs, London 1973.

Speer, Albert, Memoirs - Inside the Third Reich, London 1970.

Stachura, Peter (ed.), The Shaping of the Nazi State, London 1978.

Steiner, J.M., Power Politics and Social Change in National Socialist Germany, The Hague 1976.

Stephenson, Jill, Women in Nazi Society, London 1975.

- - The Nazi Organisation of Women, London 1981.

Stern, Fritz, Gold and Iron, Bismarck, Bleichroder and the Building of the German Empire, London 1977.

Stern, J.P., Hitler - The FUhrer and the People, London 1975.

Taylor, A.J.P., The Struggle for Mastery in Europe 1848-1918, Oxford 1954.

Trotsky, Leon, The Stuggle Against Fascism in Germany, London 1975.

Unger, Aryeh L., The totalitarian Party; party and people in Nazi Germany and Soviet Russia, London 1974.

Welch, D. (ed.), Nazi Propaganda - the Power and Limitations, London 1983.

Willoughby, L.A., German Life and Letters Volume II No. I October 1937, Oxford 1937 .

Winkler, DHrte, Frauenarbeit im Dritten Reich, Hamburg 1977.

Wright, Gordon, The Ordeal of Total War 1939-1945, New York 1968.

Wunderlich, Frieda, Farm Labor in Germany 1810-1945, Princeton 1961.

Zeman, Z.A.B., Nazi Propaganda, London 1973. 
NSV Welfare Schemes; numbers of those

receiving WHW aid/WHW; subsidies to Mutter und Kind

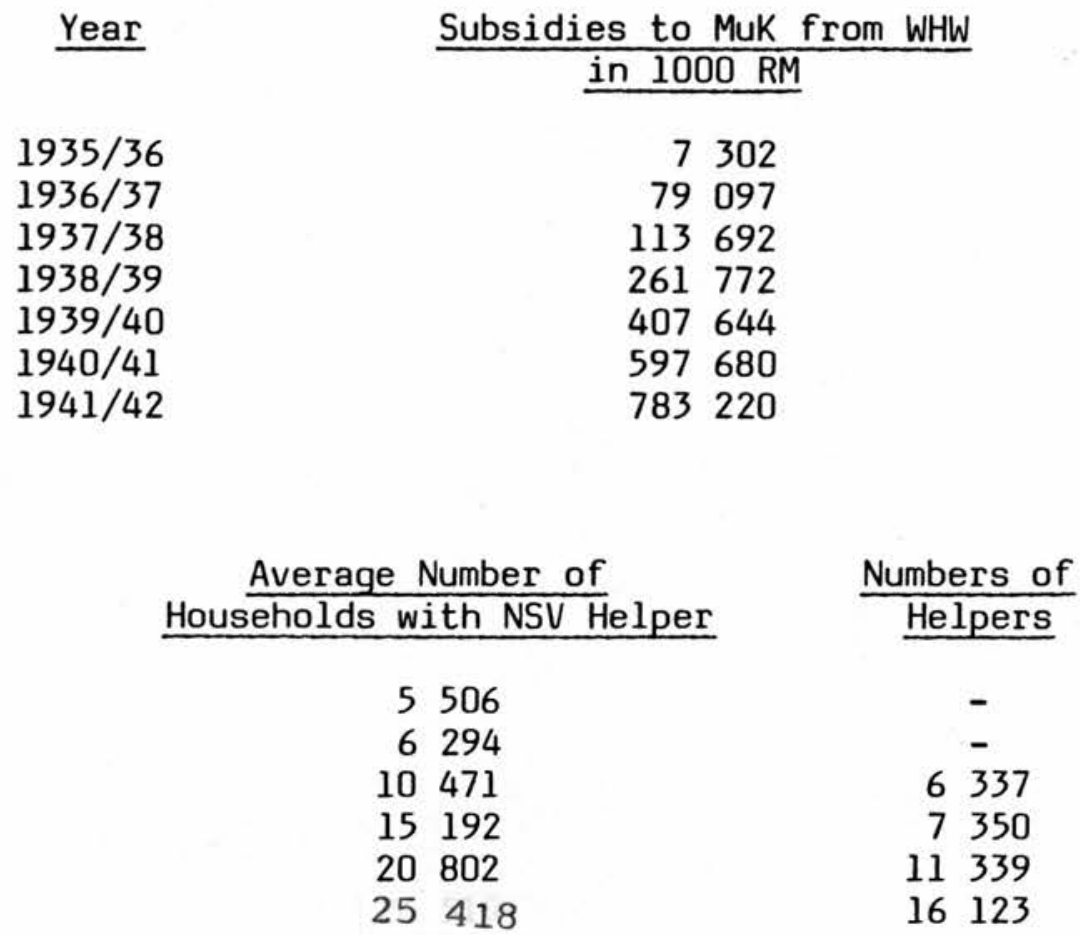

Welfare for Expectant Mothers

$\underline{\text { Year }}$

Numbers of Those Assisted

1935

1936

1937

1938

1939

1940

1941

$\begin{array}{ll}174 & 062 \\ 201 & 158 \\ 240 & 888 \\ 285 & 351 \\ 314 & 342 \\ 398 & 616 \\ 505 & 286\end{array}$

Holidays for Mothers

Year

Numbers

Receiving Holiday

1934

40340

1935

65676

1936

69876

1937

$\begin{array}{lll}77 & 169\end{array}$

1938

77723

1939

63139

1940

$55 \quad 289$

1941

62856 
NSV Health Care Stations

\begin{tabular}{|c|c|c|c|}
\hline Year & $\frac{\text { Average Number of }}{\text { Those Assisted }}$ & Home Visits & $\frac{\text { Numbers of }}{\text { Visits }}$ \\
\hline 1934 & 2332 & 48160 & 7800 \\
\hline 1935 & 37794 & 1337943 & 215690 \\
\hline 1936 & 79410 & 1830724 & 493200 \\
\hline 1937 & 112771 & 4085280 & 765990 \\
\hline 1938 & 163235 & 7087201 & 1148377 \\
\hline 1939 & 191518 & 8994007 & 1432775 \\
\hline 1940 & 210923 & 10162954 & 1669485 \\
\hline 1941 & 256629 & $12 \quad 181577$ & 2059766 \\
\hline
\end{tabular}

NSV Health Care Stations

\begin{tabular}{|c|c|c|}
\hline Year & Numbers & Nurses \\
\hline & of Stations & \\
\hline 1934 & 60 & 80 \\
\hline 1935 & 1064 & 1147 \\
\hline 1936 & 1729 & 1949 \\
\hline 1937 & 2401 & 2431 \\
\hline 1938 & 4929 & 5354 \\
\hline 1939 & 5210 & 5419 \\
\hline 1940 & 5529 & 5758 \\
\hline 1941 & 5717 & 5891 \\
\hline
\end{tabular}


Sums collected by the WHW

from 1933 to 1942

Donations from Firms and Organisations

Year

$1933 / 34$

$1934 / 35$

$1935 / 36$

$1936 / 37$

$1937 / 38$

$1938 / 39$

$1939 / 40$

$1940 / 41$

$1941 / 42$

Amounts in $1000 \mathrm{RM}$

$\begin{array}{rr}65 & 903 \\ 75 & 675 \\ 75 & 239 \\ 105 & 448 \\ 103 & 616 \\ 150 & 172 \\ 184 & 846 \\ 229 & 685 \\ 270 & 073\end{array}$

WHW: Total Income

Year

$1933 / 34$

$1934 / 35$

$1935 / 36$

$1936 / 37$

$1937 / 38$

$1938 / 39$

$1939 / 40$

$1940 / 41$

$1941 / 42$

Total Income in

358136

367425

364499

415151

418988

566352

680717

916240

1208794

Donations from Opfersonntage

Year

$1933 / 34$

$1934 / 35$

$1935 / 36$

$1936 / 37$

$1937 / 38$

$1938 / 39$

$1939 / 40$

$1940 / 41$

$1941 / 42$

Amounts 1000 RM

$\begin{array}{ll}25 & 129\end{array}$

19581

31967

33737

34742

50462

81560

163706

236987 


\section{Donations of money only}

\section{Year}

$1933 / 34$

$1934 / 35$

$1935 / 36$

$1936 / 37$

$1937 / 38$

$1938 / 39$

$1939 / 40$

$1940 / 41$

$1941 / 42$ $\underline{1000 \mathrm{RM}}$

184272

204810

234855

294310

297318

436310

631575

893654

1190635

Street Collections

Year $\frac{\text { Amounts in }}{1000 \mathrm{RM}}$

$1933 / 34$

$1934 / 35$

$1935 / 36$

$1936 / 37$

$1937 / 38$

$1938 / 39$

$1939 / 40$

$1940 / 41$

$1941 / 42$

5896

8471

18409

30532

30163

48677

84662

137200

188270

Donations from Wages and Salaries

Year

$1933 / 34$

$1934 / 35$

$1935 / 36$

$1936 / 37$

$1937 / 38$

$1938 / 39$

$1939 / 40$

$1940 / 41$

$1941 / 42$
Amounts in

1000 RM

28944

56760

62711

$\begin{array}{lll}69 & 331\end{array}$

80555

104976

131257

$\begin{array}{lll}178 & 791\end{array}$

235890 


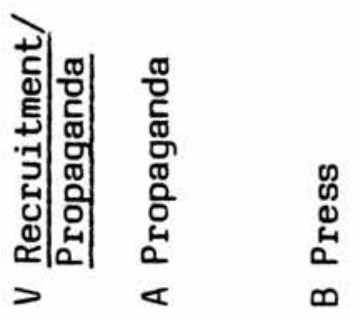

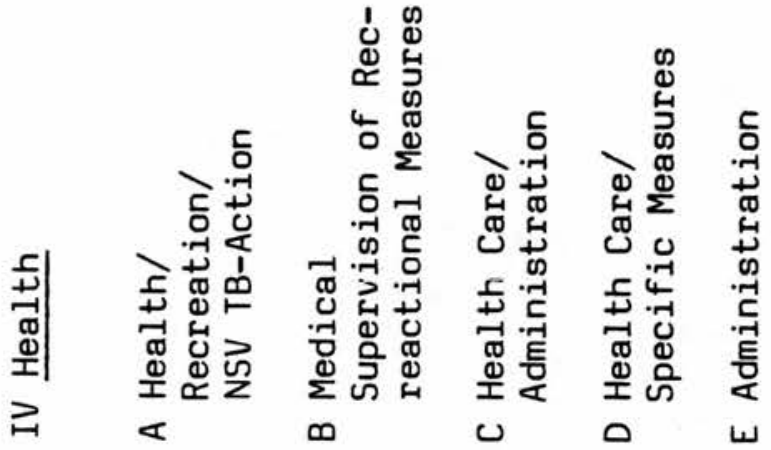
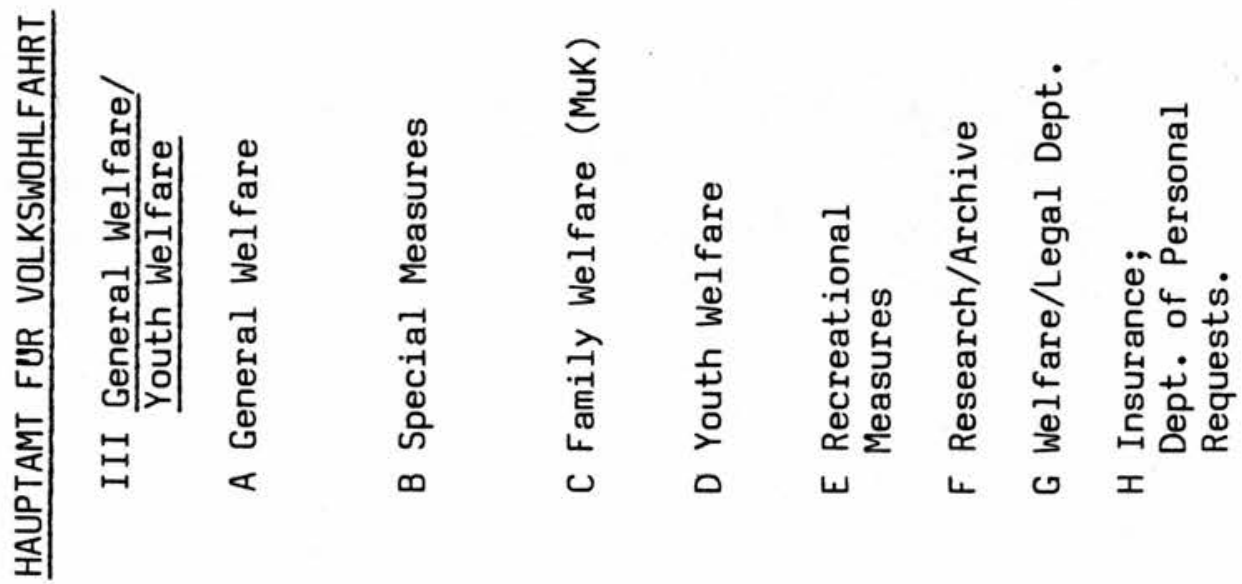

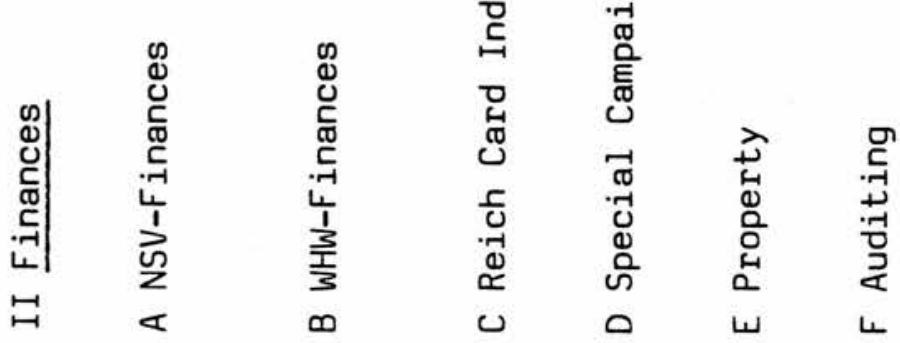

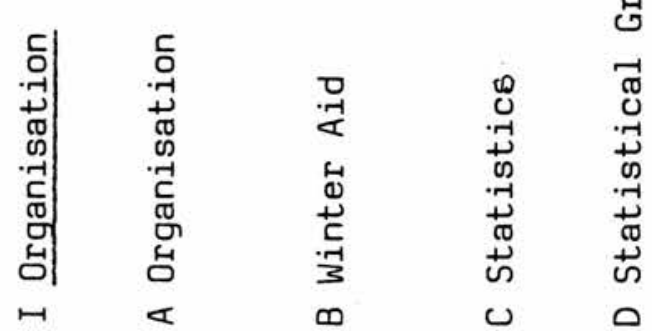




\section{Leading Officials of the NSV}

Office of the Leader of the NSV

$\mathrm{Pg}$. Dr. Stadelmann

$\mathrm{Pg}$. Lampel

Pg. Dr. Reutti

$\mathrm{Pg}$. Wendland

Organisation

Amtsleiter Pg. Wulff

Pg. Dr. Nickoll

Pg. Neumann

Pg. Lehr

Pg. Heuschmann

General Welfare and Youth Welfare

Amtsleiter Pg. Althaus

Pg. Schwietering

Generaloberin Buttger

Oberin Struckmann

Pgn. Finck

Pgn. Dr. Gilles

Pgn. Haack

Pgn. Dr. Eck

Pgn. Villnow

Pgn. Mansfeld

Pgn. Derks

\section{Finance}

Pg. Pirk

Pg. Kreynfeld

Pg. Schultze

Pg. Richter

Pg. Dr. Woy

Pg. Gravenstein

Pg. Thiess

Pg. Vansolow

Pg. Fuchs

Pg. Muller

$\mathrm{Pg}$. Hooge

Pg. Grunberg

Pg. Schmidt

$\mathrm{Pg}$. Meyer

Health

Amtsleiter Pg. Dr. Strohschneider Pgn. Dr. Stark

Pgn. Dr. Lugauer

Pgn. Dr. Popp

Pgn. Dr. Kuhl

Training and Propaganda

$\begin{aligned} & \text { Amtsleiter } \text { Pg. Hebenbrock } \\ & \text { Pg. Reher } \\ & \text { Pg. Hahm } \\ & \text { Pg. Fernkorn } \\ & \text { Pg. Leusch } \\ & \text { Pg. Vollmann } \\ & \text { Pg. Dr. Ohling } \\ & \text { Pg. Bernsee } \\ & \text { Pg. Gaderer } \\ & \text { Pg. Bartelt } \\ & \text { Pg. Rees } \\ & \text { Pg. Maschke }\end{aligned}$

NS-Reichsbund Deutscher

Schwestern

Reichsoberin Moser

Oberin Schadow

Oberin v. Klitzing

Oberschwestr Hildegard Schewe

Oberschwester Ruth Duhe 


\section{Glossary}

BA

BdM

DFO

DGT

DFW

Gau

Haushalthilfe

HA

HJ

$\underline{\text { Kampfzeit }}$

KPD

Kreis

Machtubernahme

n.d.

n.p.

MuK

NSDAP

NSF
Bundesarchiv, Koblenz.

Bund deutscher Madel (league of German Girls), female branch of the Hitler Youth, for girls over 14 years of age.

Deutscher Frauenorden (German Women's Order), v8lkisch women's organisation founded by Elsbeth Zander in 1923 and merged with other groups into the NSF in 1931.

Deutscher Gemeindetag (headed by Karl Fiehler) this official body represented the interests of state officials, DGT head office was in Berlin.

Deutsches Frauenwerk (German Women's Enterprise), the Nazi-led federation of women's groups from 1934 to 1945 .

(region) the major territorial division of the national NSDAP organisation; there were 32 Gaus in 1933, 40 in the Greater German Reich of 1938.

NSV measure which provided domestic helpers for families in need of assistance.

NSDAP Hauptarchiv, the Party's own archival collection, started in January 1934.

Hitler Jugend (Hitler Youth), the Nazi Party's youth organisation.

(time of struggle), the years from the founding of the NSDAP until the Nachtubernahme.

Kommunistische Partei Deutschlands (German Communist Party).

(district), territorial unit of the NSDAP into which the Gaus were divided.

takeover of power

Date of publication not given.

Place of publication not given.

Mutter und Kind, NSV section for welfare for mothers and infants formed in 1934.

Nationalsozialistische Deutsche Arbeiterpartei.

Nationalsozialistische Frauenschaft (Nazi Women's Group), the Party organisation for women founded in 1931. 

founded in May 1933.

NSVJ

NS-Jugendhilfe, the NSV's youth welfare section formed in 1934 to provide additional juvenile care.

Ortsgruppe

(local branch), territorial unit of the NSDAP into which the districts were divided.

Reichsleitung (National Leadership), the highest decision-making level of the NSDAP.

Reichsmütterdienst (Reich Mothers' Service) the provision of training courses in child-care and housewifery run by the DFW/NSF .

RJF

Reichsjugendfuhrer (National Youth Leader), the title conferred on Baldur van Schirach in October 1931.

RJFg

Reichsjugendfuhrung (National Youth Leadership), Schirach's office.

SA

Sturm Abteilungen (Storm Troopers), paramilitary formation of the NSDAP.

SPD

Sozialdemokratische Partei Deutschlands (German Social Democratic Party).

SS

Schutzstaffeln, Nazi elite paramilitary formation, under the leadership of Heinrich Himmler.

VB

Vulkșcher Beobachter, official Nazi Party newspaper.

Vylkisch (racist-nationalist), the generic term used to describe aims and groups similar to those of the NSDAP, especially in the 1920's.

Volksdeutsch (ethnic German), used by the NSDAP to describe ethnic Germans living outside the Reich.

Volksgemeinschaft The 'people's national community' the new social order of the Nazis based on the values of 'community' and self-sacrifice.

Weltanschauung (world view) term used to indicate the Nazis philosophical frame of reference regarding the destiny of the nation.

WHW

Winterhilfswerk, NSV annual charity scheme which provided help in kind in the months of the winter for those (mainly families, rather than individuals) with low incomes. 